$$
\begin{gathered}
\text { SZEGEDI TUDOMÁNYEGYETEM } \\
\text { BÖLCSÉSZETTUDOMÁNYI KAR } \\
\text { TÖRTÉNETTUDOMÁNYI DOKTORI ISKOLA }
\end{gathered}
$$

MODERN KORI DOKTORI PROGRAM

MAGYARORSZÁG 16-20. SZÁZADI ESZMETÖRTÉNETE ALPROGRAM

\title{
BALOGH ISTVÁN POLITIKAI PÁLYÁJA
}

\author{
DOKTORI (PHD) ÉRTEKEZÉS
}

Készítette:

Miklós Péter

Témavezető:

Dr. habil. Marjanucz László CSc

tanszékvezető egyetemi docens

SZEGED

2012 


\section{TARTALOM}

I. BEVEZETÉS

I. 1. A kutatás célja, módszertana és forrásai 4

I. 2. A téma historiográfiája 5

II. KORMÁNYZATI, POLITIKAI ÉS IDEOLÓGIAI ÁTALAKULÁSOK

MAGYARORSZÁGON A KOALÍCIÓS ÉVEKBEN 7

II. 1. Változások a kormányzatban és az államigazgatásban 7

II. 2. A politikai élet főbb tendenciái 18

III. A SZEGEDI ÉVEK 25

III. 1. Családja, tanulóévei 25

III. 2. Tudományos és egyházi kapcsolatai, doktori értekezése 28

III. 3. Első politikai csatározásai Szegeden 34

III. 4. A Szeged-alsóközponti plébánián 39

III. 5. Vita a föispánnal, lelkipásztori feladatok az 1940-es évek első felében $\quad 49$

III. 6. Lemondás a szeged-alsóközponti plébániáról 53

$\begin{array}{ll}\text { IV. AZ ÁLLAMTITKÁR } & 70\end{array}$

$\begin{array}{ll}\text { IV. 1. A sajtóügyek felelőse } & 70\end{array}$

IV. 2. Kapcsolata a Délmagyarországgal az 1940-es években 85

IV. 3. A földbirtokreformmal kapcsolatos ügyek előadója $\quad 106$

IV. 4. A katolikus egyházi érdekek képviselete 115

V. A KÉKCÉDULÁS VÁLASZTÁSOKTÓL AZ INTERNÁLÁSIG 123

V. 1. A Független Magyar Demokrata Párt elnöke 123 
V. 3. Az állam és egyház közötti megegyezés sürgetése,

a politikai karrier vége

VI. EPILÓGUS

VII. ÖSSZEGZÉS

158

VIII. FELHASZNÁLT FORRÁSOK, IRODALOM

IX. FÜGGELÉK: BALOGH ISTVÁN PARLAMENTI BESZÉDEIBÖL

(DOKUMENTUMKÖZLÉS)

IX. 1. A kormány rendeletalkotásra való felhatalmazásáról

(1947. október 28.)

IX. 2. A magyar-csehszlovák barátsági szerződésről

(1949. június 15.)

IX. 3. Magyarország alkotmányáról

(1949. augusztus 17.)

IX. 4. Az első ötéves tervről 


\section{BEVEZETÉS}

\section{1. A kutatás célja, módszertana és forrásai}

Balogh István életútjáról és politikai pályájáról monografikus igényü feldolgozás még nem készült. Doktori értekezésem célja, hogy - elsősorban levéltári kutatásaim fényében - minél árnyaltabban és részletesebben mutassam be Balogh páter politikai pályáját.

Dolgozatomban Balogh fiatalkoráról, illetve életének Kádár-korszakbéli szakaszáról csak röviden írok. Munkám fókuszában a tevékeny politikai szereplő Balogh páter áll, aki az 1920-as évek közepétől előbb a szegedi várospolitikában, majd 1944-től az országos „nagypolitikában” müködött. Politikai karrierje 1951 júniusában ért véget, amikor el kellett hagynia a fővárost, s országgyülési képviselői mandátumáról is lemondott.

Értekezésemben külön fejezetben tárgyalom szegedi politikai és lelkészi tevékenységét (1926-1944), valamint államtitkári (1944-1947) és pártelnöki, illetve országgyülési képviselői (1949-1951) munkáját. A dolgozat függelékeként külön egységben - magyarázó és értelmező jegyzetekkel ellátva - közlöm négy parlamenti beszédét, amelyek véleményem szerint képet adnak mind Balogh politikai irányvonaláról, mind a korszak közhangulatáról.

Az értekezés összeállítását levéltári és könyvtári kutatómunka előzte meg. A Magyar Országos Levéltár dokumentumai és az Országos Széchényi Könyvtárban őrzött kéziratok tanulmányozása mellett a Csongrád Megyei Levéltárban, a SzegedCsanádi Püspöki Levéltárban, valamint a Politikatörténeti és Szakszervezeti Levéltárban kutattam, de az Állambiztonsági Szolgálatok Történeti Levéltára és a Bács-Kiskun Megyei Önkormányzat Levéltára kezelésében lévő iratok közül is többet fölhasználtam 
dolgozatom készítésekor. Ezeken kívül számos korabeli hírlapot átolvastam, s az azokban szereplő cikkek, publicisztikák, tudósítások adatait beépítettem munkámba. ${ }^{1}$

\section{2. A téma historiográfiája}

Balogh páter életútját elöször Balázs György tekintette át röviden a Politikuspályák (1984) kötetben. ${ }^{2}$ Szegedi politikai tevékenységéről Ruszoly József írt Balogh páter szegedi közszerepléséhez címmel a Szeged folyóirat 1997. évi első számában, majd publikálta $A$ Város és polgára (1999) címü kötetében is. ${ }^{3}$

A Huszadik Század Intézet Korrajz, 2002 címü évkönyvében (2004) jelent meg Klettner Csilla Balogh István páter politikai pályája címü tanulmánya, amelyben a szerző alapos levéltári kutatásai, korabeli hírlapi források, valamint Balogh - a Politikatörténeti Intézet Levéltárában örzött - emlékezései alapján mutatta be a páter pályáját. ${ }^{4}$ Az 1947-1949-es országgyülés 2005-ben kiadott almanachja számára M. Kiss József és Szabó Róbert foglalta össze - az addigi fontosabb kutatási eredmények fölhasználásával - Balogh István életrajzát. ${ }^{5}$

Haas György Balogh páter. A huszadik század Fráter Györgye címü könyve 2010-ben jelent meg. Inkább publicisztikai írás, mint szaktanulmány, s lényegében Klettner Csilla hat évvel korábban közölt eredményeit ismételte meg benne a szerző. ${ }^{6}$

\footnotetext{
${ }^{1}$ A dolgozathoz használt levéltári források és korabeli sajtótermékek részletes fölsorolása a nyolcadik fejezetben található.

${ }^{2}$ Balázs György: Balogh István. In: Politikuspályák. Szerk. Sánta Ilona. Budapest, 1984. (a továbbiakban: Balázs György, 1984) 233-243.

${ }^{3}$ Ruszoly József: Balogh páter szegedi közszerepléséhez. In: Uő: A Város és polgára. Szeged, 1999. (a továbbiakban: Ruszoly József, 1999) 138-143. Első megjelenése: Szeged, 10 (1997). 1. sz. 30-32.

${ }^{4}$ Klettner Csilla: Balogh István páter politikai pályája. In: Korrajz, 2002. A XX. Század Intézet Évkönyve. Budapest, 2004. (a továbbiakban: Klettner Csilla, 2004) 96-127.

${ }^{5}$ M. Kiss József - Szabó Róbert: Balogh István. In: Az 1949. szeptember 16-ra összehívott országgyülés almanachja. 1947. szeptember 16. - 1949. április 12. Főszerk. M. Kiss József, Vida István. Budapest, 2005. (a továbbiakban: M. Kiss József - Szabó Róbert, 2005) 30-31.

${ }^{6}$ Haas György: Balogh páter. A huszadik század Fráter Györgye. Szeged, 2010. (a továbbiakban: Haas György, 2010)
} 
Újabban Pelle János írt Balogh páterről (Balogh páter, a koalíció „,szürke eminenciása”) a Valóság 2011. évi negyedik számában, jórészt szintén Klettner korábbi kiváló kutatásaira támaszkodva. ${ }^{7}$

\footnotetext{
${ }^{7}$ Pelle János: Balogh páter, a koalíció ,szürke eminenciása”. Valóság, 54 (2011). 4. sz. (a továbbiakban:
} Pelle János, 2011) 92-96. 


\section{KORMÁNYZATI, POLITIKAI ÉS IDEOLÓGIAI ÁTALAKULÁSOK MAGYARORSZÁGON A KOALÍCIÓS ÉVEKBEN ${ }^{8}$}

\section{1. Változások a kormányzatban és az államigazgatásban}

Mivel Balogh István országos politikai szerepvállalása - államtitkári megbízatása - a koalíciós évekre esett, indokolt az ezen időszakban bekövetkezett meglehetősen radikális - kormányzati, politikai és ideológiai változásait áttekintetni.

1944. október 16-án - egy nappal a sikertelen kiugrási kísérlet után - Horthy Miklós miniszterelnökké nevezte ki Szálasi Ferencet, majd lemondott a kormányzói méltóságról. 1944. október 27-én az államfői jogkör - igaz, ideiglenes - gyakorlására az Országtanács Szálasit nemzetvezetővé választotta. A kétkamarás törvényhozás képviselőházának és felsőházának pozíciójukban maradt tagjaiból létrehozott Törvényhozók Nemzeti Szövetsége - 1944. december 1-jétől soproni székhellyel 1945. március 28-ig müködött

1944. december 14-én alakult meg az Ideiglenes Nemzetgyülés Elökészítő Bizottsága, amely tizenkét megbízotti csoportot szervezett. Ezek a csoportok a szovjet hadsereg teherautóin körbejárták a front mögötti országrész településeit és a nagyobb állami épületekben vagy a köztereken népgyüléseket tartottak. Ezeken tájékoztatták a lakosságot, hogy új törvényhozó testületet szerveznek, amelynek tagjainak a megválasztását le is bonyolították. Így 1944. december 20-án 44 kelet-magyarországi településről 230 képviselőt vittek az Előkészítő Bizottság megbízottjai Debrecenbe, ahol másnap - Vorosilov kérésére, aki az eseményt Sztálin születésnapjára szerette volna időzíteni - megtartotta alakuló ülését az Ideiglenes Nemzetgyülés. Az új - sebtében összejött és meglehetösen archaikus körülmények között megalakult - törvényhozó

\footnotetext{
${ }^{8}$ Az ebben a fejezetben megfogalmazottak az A magyar állam története címủ kötetbe írt összefoglalásom logikáját követik. Vö. Miklós Péter: A koalíciós évek állama. 1944-1945. In: A magyar állam története. 1711-2006. Szerk. Szabó Pál Csaba. Szeged, 2010. 205-222.
} 
testület olyannyira ügyelt legitimitására, hogy a képviselők a megbízólevelét mandátumvizsgáló bizottság hitelesítette. ${ }^{9}$

A formális megalakulás után megválasztották a - feladatkörének, létrejöttének és létkörülményeinek bizonytalanságát a nevében szereplő ,ideiglenes” jelzővel is elismerő - nemzetgyülés tisztségviselőit. A házelnök Zsedényi Béla jogászprofesszor lett $^{10}$, az alelnöki tisztségre pedig Juhász Nagy Sándor jogászprofesszort és Sánta Kálmán orvosprofesszort választották. Feladatuk volt az ülések összehívása, vezetése, a nemzetgyülési bizottságok létrehozásának kezdeményezése és azok megszervezése. A nemzetgyülés létszáma kétszer bővült: 1945. április 2-án a Budapesten megválasztott képviselőkkel, 1945. június 24-én pedig a dunántúli területekről küldött tagokkal gyarapodott a testület 498 fösre. A háznak két ülésszaka volt: Debrecenben 1944 decemberében (alig nyolc órán keresztül) és Budapesten 1945 szeptemberében (hat napig). Bár Zsedényi Béla, az Ideiglenes Nemzetgyülés elnöke többször - 1945 márciusában és májusában is - kezdeményezte az összehívást, erre a - szovjet befolyás alatt álló - Szövetséges Ellenőrző Bizottságtól nem kapott engedélyt. ${ }^{11}$

$\mathrm{Az}$ Ideiglenes Nemzetgyülés tényleges törvényhozó, jogalkotó tevékenységet alig folytatott. Ennek oka egyrészt, hogy nem szabályozott, általános választásokon nyerte megbízatását, másrészt, hogy sem a Szövetséges Ellenőrző Bizottság (SZEB), sem a politikai elitben már ekkor is túlreprezentált Magyar Kommunista Párt (MKP) nem nézte volna jó szemmel a túl aktív parlamenti munkát. Jelentősége viszont vitathatatlan, hiszen előkészítette a szabad választásokat, megválasztotta és megfelelő jogkörrel ruházta fel az Ideiglenes Nemzeti Kormányt, utólag törvényerőre emelte annak legfontosabb rendeleteit $\mathrm{s}$ a népszuverenitást képviselve szakított a Horthykorszak jogfolytonosságával. ${ }^{12}$

\footnotetext{
${ }^{9}$ Korom Mihály: Az Ideiglenes Nemzetgyülés és az Ideiglenes Nemzeti Kormány létrejöttének hazai és nemzetközi körülményei. In: Az Ideiglenes Nemzetgyülés és az Ideiglenes Nemzeti Kormány. 19441945. Szerk. Feitl István. Budapest, 1995. 29-50.

${ }^{10}$ Zsedényiröll lásd bővebben: Ruszoly József: Zsedényi Béla. In: Uő: Három borsodi örökhagyó. Palóczy László, Szemere Bertalan, Zsedényi Béla. Miskolc, 1992. 117-187. és Gantner Péter: Egy elfelejtett államfö. Zsedényi Béla életpályája. Budapest, 2008. 7-257.

${ }^{11}$ Gyarmati György: A parlamentarizmus korlátai és annak következményei az Ideiglenes Nemzetgyülés tevékenységére. In: Az Ideiglenes Nemzetgyülés és az Ideiglenes Nemzeti Kormány. 1944-1945. Szerk. Feitl István. Budapest, 1995. 152-170.

${ }^{12}$ Korom Mihály: Magyarország Ideiglenes Nemzeti Kormánya és a fegyverszünet. Budapest, 1992. 311 509.
} 
Mivel a ház csak néhány napot ülésezett, a gyakorlati jogalkotó tevékenységet mintegy „kis nemzetgyülésként” - az Ideiglenes Nemzetgyülés Politikai Bizottsága végezte. Huszonkét tagját a nemzetgyülési arányoknak megfelelően delegáltak a szervezetek: a Független Kisgazdapárt (FKGP) 5, az MKP és a Szociáldemokrata Párt (SZDP) 4-4, a Nemzeti Parasztpárt (NPP) 3, a Polgári Demokrata Párt (PDP) 2, a függetlenek 5 tagot. Hozzájuk csatlakozott huszonharmadikként az Ideiglenes Nemzetgyülés Elnökségének képviselője. A - létszámánál fogva könnyebben és gyorsabban összehívható, kizárólag nemzetgyülési képviselőkből álló - Politikai Bizottság ellenőrizte a kormányt, a front nyugatra húzódásával intézkedett a nemzetgyülés kiegészítéséröl és - 1945 májusa és szeptembere között - döntött az öt parlamenti bizottság (gazdasági, véderő, birtokpolitikai, alkotmányjogi, mentelmi) felállításáról a két nagy ülésszak között.

Az Ideiglenes Nemzetgyülés Politikai Bizottsága 1945. május 11-én döntött arról, hogy az Magyar Nemzeti Függetlenségi Frontnak (MNFF) négy párt a tagja (FKGP, MKP, SZDP, NPP), s abba újabb szervezeteket nem kívánnak felvenni. Ezzel a - kétségtelenül súlytalan, baloldali - Polgári Demokrata Pártot de iure kizárták a koalícióból, gyakorlatilag azonban a párt elnöke, Teleki Géza gróf vallás- és közoktatásügyi miniszterként tevékenykedett a Miklós-kormányban, annak szinte (két nap kivételével) teljes megbízatása alatt. Kiestek azonban a PDP megbízottjai a nemzeti bizottságokból, népbíróságokból, igazoló bizottságokból. A pártalakításhoz a SZEB jóváhagyására volt szükség, amit az nagyon nehezen adott meg, mivel a túl sok pártban és túlságosan plurális demokratizálódásban a szovjet megszálló hatalom nem volt érdekelt. $^{13}$

Erdei Ferenc belügyminiszter 1945. szeptember 11-én nyújtotta be a választójogi törvényjavaslatot, amelyet az Ideiglenes Nemzetgyülés utolsó munkanapján, 1945. szeptember 13-án fogadott el. Az 1945. évi VIII. törvény kimondta az általános, titkos, egyenlő és közvetlen választójog elvét. Választójogát minden 20. életévét betöltött férfi és nő gyakorolhatta, aki 1937. december 31-én Magyarország határian belül élt. Tizennyolc éves koruktól szavazhattak azok, akik részt vettek az antifasiszta ellenállásban. A választási jogszabályok betartására és a választások koordinálására létrehozták az Országos Nemzeti Bizottságot. A választási bíráskodás jogkörét elvették a Közigazgatási Bíróságtól, és életre hívták a Választási Bíróságot, amelynek azonban

\footnotetext{
${ }^{13}$ Izsák Lajos: Rendszerváltástól rendszerváltásig. 1944-1990. Budapest, 1998. 40-41.
} 
ekkor még nem sok dolga akadt, az 1945-ös választások után senki sem nyújtott be petíciót. $^{14}$

Az országban megszüntették a hagyományos egyéni választókerületi rendszert és helyette tizenhat, nagy kiterjedésű választókerületet hoztak létre, amelyekben nem egyéni jelöltekre, hanem pártlistákra lehetett szavazni. Minden 12000 szavazat után járt egy mandátum. A választási eredmény alapján a pártok között további ötven mandátum került betöltésre az országos listáról. Emellett az új nemzetgyülés további tíz tagot választhatott tagjai közé, az ország szellemi elitjéből, mintegy pótolva - kétkamarás parlament híján - a felsőházat. Végül ilyen módon tizenkét képviselőt hívtak be (azonban létszámukat csak később, az 1946. évi XI. törvénnyel emelték föl), köztük Kodály Zoltánt, Szent-Györgyi Albertet, Pátzay Pált, Tamási Áront, Szőnyi Istvánt és dálnoki Miklós Bélát.

Az Ideiglenes Nemzetgyülés 1944. december 22-én megválasztotta az Ideiglenes Nemzeti Kormányt. A képviselők egyhangúlag szavazták meg a miniszterelnököt, a kormánylistát és hatalmazták fel őket az ország ügyeinek vezetésével, ezzel jogi alapot teremtve a kormány rendeletalkotó és -kibocsátó munkájához, amivel élt is, hiszen a minisztertanács 1945 szeptemberéig 367 kormányrendeletet alkotott és adott ki.

Az Ideiglenes Nemzeti Kormány 1944. december 22. és 1945. november 15. között, kétszeri - az 1945. május 11-i és az 1945. július 21-i - átalakítással müködött. Miniszterelnök: dálnoki Miklós Béla. Belügyminiszter: Erdei Ferenc, földművelésügyi miniszter: Nagy Imre, honvédelmi miniszter: Vörös János, igazságügy-miniszter: Valentiny Ágoston (1945. július 21-ig, utána Ries István), iparügyi miniszter: Takács Ferenc (1945 június 1-jéig, utána Bán Antal), kereskedelem- és közlekedésügyi miniszter: Gábor József (1945. május 9-ig, utána Gerő Ernő), külügyminiszter: Gyöngyösi János, népjóléti miniszter. Molnár Erik, pénzügyminiszter: Vásáry István (1945. július 21-ig, utána Oltványi Imre), vallás- és közoktatásügyi miniszter: Teleki Géza gróf, újjáépítési miniszter (1945. május 11-től): Nagy Ferenc. ${ }^{15}$

Az Ideiglenes Nemzeti Kormány gondoskodott a polgári szabadságjogokat súlyosan korlátozó intézkedések orvoslásáról. 1945. február 5-én visszavonta a zsidótörvényeket és -rendeleteket, négy nappal később pedig rendeletet adott ki a faji és vallási hovatartozásuk miatt fogságban lévők szabadon bocsátásáról, a menekültek, az

\footnotetext{
${ }^{14}$ Berényi Sándor: A magyar népi demokratikus állam közigazgatása. 1945-1955. Budapest, 1987. 5-67.

${ }^{15}$ Bölöny József: Magyarország kormányai. 1848-1992. Budapest, 1992. 94-95.
} 
áttelepítettek és a hontalanok védelméröl. 1945 februárjában egy kormányrendelet betiltotta a szélsőjobboldali és fasiszta pártokat, szervezetek, egyesületeket, köztük a Szálasi vezette Nyilaskeresztes Pártot, a Magyar Nemzetiszocialista Pártot, az Imrédyféle Magyar Megújulás Pártját és az egykor kormányzó Magyar Élet Pártját.

Az államfő jogköre - mivel a királyság, mint államforma továbbra is fennállt, azonban sem a trón, sem a kormányzói tisztség nem volt betöltve - az Ideiglenes Nemzetgyülés Elnöksége, az Ideiglenes Nemzeti Kormány, a miniszterelnök személye és a Nemzeti Fötanács között oszlott meg. A nemzetgyülés vezetői nevezték ki a politikai államtitkárokat, a Kúria elnökét, a Közigazgatási Bíróság elnökét, a Legfőbb Állami Számvevő Szék elnökét, a tábornoki kar tagjait. A Politikai Bizottság 1945. január 26-i döntése alapján adták ki az 59/1945. M. E. számú rendeletet a Nemzeti Főtanács létrehozásáról. Tagjai: a házelnök (vagy helyettese), a miniszterelnök (vagy helyettese), és egy olyan nemzetgyülési képviselő, aki nem tagja a kormánynak (Gerő Ernő - miniszterré történt kinevezéséig -, utána Révai József). A Nemzeti Főtanácsot reprezentatív (követek küldése és fogadása) és szimbolikus (nemzetközi szerződések kötése, halálos népbírósági ítéletek enyhítése) jogkörén kívül a kinevezések joga is megillette (miniszterek, bizonyos állami és közigazgatási vezetők esetében, illetve címek, kitüntetések alapítása és adományozása). Valamint önálló hatáskörben dönthetett kisebb jelentőségü ügyekben: például a házassági akadályok alóli felmentésről, vagy a törvénytelen gyermekek törvényesítéséről. ${ }^{16}$

Az 1945 végén megválasztott és összeült nemzetgyülés egyik legfontosabb feladata az államforma rendezésének a kérdése volt. Először a szociáldemokrata Szeder Ferenc jelentette ki a nemzetgyülésen 1945. december 1-jén, hogy pártja - amely a két világháború között is határozottan vállalta a republikánus eszmét és annak 1918-as hagyományait - kiáll a köztársasági államforma megteremtése mellett. Ehhez 1946 elejére a többi baloldali párt is csatlakozott. Az FKGP azonban óvatosabb volt. A nagy és sokféle csoportot magában foglaló szervezet tagságára és szavazótáborára ugyanis nagy hatással volt a katolikus egyház. A katolikus klérus pedig - élén Mindszenty József hercegprímással - legitimista nézeteket vallott, s ha a trón betöltését nem is akarta, de a királyság államformáját változatlanul fenn kívánta tartani. A kisgazdapárt képviselőinek egy része (több mint száz politikus) memorandumban fordult a

16 Föglein Gizella: Az államfői intézmény és a az Ideiglenes Nemzetgyülés. In: Az Ideiglenes Nemzetgyülés és az Ideiglenes Nemzeti Kormány. 1944-1945. Szerk. Feitl István. Budapest, 1995. 137150 . 
pártvezetéshez, hogy az államforma kérdését vegye le a napirendről és halassza a békekötés utáni időkre.

Később azonban a kisgazda vezetés és a frakció nagyobb része a köztársaságot támogatta. Egyrészt, mert a környező országokban már megszűnt a monarchia, másrészt az amerikai és brit nagykövetek tudomásukra hozták, hogy nem ellenzik a Magyar Köztársaság kikiáltását, harmadrészt pedig - mint győztes pártot - őket illeti meg az államfö jelölésének a joga. 1946 elejére az MKP, az FKGP és az SZDP is kidolgozott egy-egy tervezetet az állami főhatalomról. A kommunista javaslat szét akarta választani az államföi és a végrehajtó hatalmat. Nagy súlya lett volna a parlament Politikai Bizottságának, amelynek kétharmados támogatása kellett volna szinte valamennyi elnöki intézkedéshez. Korlátozott elnöki jogkört szerettek volna, ahol az államfö keze teljesen meg van kötve a nemzetgyülés által.

A kisgazdák által kidolgozott tervezet jóval konzervatívabb volt. Ök a végrehajtó hatalom fejeként képzelték el az elnököt, akinek joga van felmenti és kinevezni a miniszterelnököt, a hadsereg föparancsnokát és gyakorolhatja a katolikus egyház felett a fökegyúri jogot. Sőt, a nemzetgyülést is feloszlathatná saját jogon, ha garantálja, hogy 60 napon belül ismét összehívja. Az MKP és az FKGP tervezete között helyezkedett el a szociáldemokraták javaslata, akik egy szuverén, ugyanakkor erős parlamentáris kontroll alatt álló elnököt akartak a köztársaság élén látni. A kormányfőt kinevezhette, illetve felmenthette volna, de hadúri és főkegyúri jogokkal nem lett volna felruházva. A nemzetgyülést csak akkor oszlathatta volna fel, ha az tartósan munkaképtelenné válna. Hatalmát a minisztériumokon keresztül gyakorolná, amelyek a nemzetgyülésnek felelösek. ${ }^{17}$

Ennek a három tervezetnek a felhasználásával született meg az a kompromisszumos törvényjavaslat, amelyet a nemzetgyülés 1946. január 31-én elfogadott. Az 1946. évi I. tc. értelmében Magyarország köztársaság lett. Képviseletére a köztársasági elnök jogosult, aki a végrehajtó hatalmat a nemzetgyülésnek felelős miniszterek útján gyakorolta. A kormányzásban közvetlenül nem vehetett részt, a miniszterelnököt a Politikai Bizottság döntésének és többségi elv figyelembe vételével nevezhette ki és menthette fel, a minisztereket pedig a kormányfő előterjesztése alapján. Az elnök követeket küldhetett és fogadhatott, konzulokat nevezhetett ki, de háború és béke kérdésében, illetve külhatalmakkal kötött szerződés esetén a nemzetgyülés

\footnotetext{
${ }^{17}$ Föglein Gizella: Államforma és államföi jogkör Magyarországon. 1944-1949 Budapest, 1993. 39-66.
} 
felhatalmazására volt szüksége. Megillette a kegyelmezés, valamint háború esetén a honpolgári kötelékből való elbocsátás joga. Ezek azonban politikailag nem sokat nyomtak a latba. A nemzetgyülés feloszlatására a kormány javaslatára, a képviselők 40\%-ának előterjesztése esetén volt joga.

A megvalósult köztársasági elnöki intézmény erősen korlátozva volt a baloldali befolyás alatt álló - Politikai Bizottság által. Az államfő személyére a kisgazdapárt tehetett javaslatot. Felmerült ugyan Nagy Ferenc neve is, végül mégis - a kisgazdák és a baloldali pártok támogatásával - a demokratikus országot vezető első miniszterelnököt, Tildy Zoltánt választották köztársági elnökké közfelkiáltással 1946. február 1-jén. A radikálisok és a szociáldemokraták egy része jelölte volna ugyan az emigrációból visszatért Károlyi Mihályt, az 1918. évi népköztársaság elnökét, neki azonban be kellett érnie érdemeinek törvénybe foglalásával és némi anyagi kárpótlással (1946. évi II. tc.).

A köztársasági elnöki méltóságot azonban csak ketten töltötték be. Tildy Zoltán 1946. február 1. és 1948. augusztus 3. között, valamint Szakasits Árpád 1948. augusztus 3. és 1949. augusztus 23. között. A kiépülő kommunista diktatúrára jellemző és Magyarország sikeres szovjetizálásának jelképes eseményeinek tekinthetjük, hogy mindkét államfő megbízásának lejárta előtt - a Rákosi-klikk nyomására - lemondásra kényszerült. Mindkettejüket bíróság elé állították, ahol életfogytiglani börtönbüntetésre ítélték őket. ${ }^{18}$

1944 októberében, a szovjet csapatok uralma alá került területen a helyi közigazgatás biztosítására megszervezték a népi bizottságokat, amelyek az MNFF 1944. decemberi megalakulása után egységesen nemzeti bizottságoknak kezdetek nevezni. A nemzeti bizottságok tagjai a pártok és a szakszervezetek delegáltjai voltak. ${ }^{19}$

A kormány 1945. január 4-én rendeletet adott ki a régi közigazgatás és önkormányzatok mielőbbi helyreállításáról. A paritás elve alapján szerveződő - ezáltal baloldali többségü - nemzeti bizottságok müködése azonban a hatalomba igyekvő MKP-nak inkább érdekében állt, mint a helyi önigazgatás visszaállítása és a törvényhatósági választások megtartása. Ez nem kis feszültséget okozott a koalícióban, hiszen az erős, nagy taglétszámmal rendelkező FKGP éppen a helyi választásoktól várta

\footnotetext{
18 Feitl István - Palasik Mária: Magyar köztársaság. 1946. In: Demokratikus köztársaságok Magyarországon. Szerk. Feitl István, Gellériné Lázár Mára, Kende János. Budapest, 2007. 73-129.

${ }^{19}$ Vö. Korom Mihály: A népi bizottságok és a közigazgatás Magyarországon. 1944-1945. Budapest, 1984. 172-188.
} 
a közigazgatásra és az állami életre gyakorolt befolyásának növekedését. Törvényhatósági választást azonban csak a fövárosban tartottak.

Az Ideiglenes Nemzeti Kormány 15/1945. M. E. számú rendeletével állította fel az igazoló bizottságokat. A bizottságok feladata a közalkalmazottak igazolása volt, azaz hogy nem követtek el háborús és népellenes bünöket 1945 előtti közigazgatási munkájuk során. A közigazgatási tisztviselőkön kívül az oktatási életben, a társadalmi szervezetekben tevékenykedőknek, valamint a nagy állami támogatást kapó ipari és kereskedelmi vállalatok alkalmazottainak is igazolniuk kellett magukat. Az igazoló bizottságok tagjait is az öt párt adta, akik maguk közül választottak elnököt, rajtuk kívül az illetékes föispán vagy vállalatvezető is delegálhatott tagot a testületbe. Munkájukat egy jogvégzett szakember is segítette. Ha a bizottság az igazolást nem adta ki, elbocsátással vagy internálással szankcionálhatta az alkalmazottat, ha pedig büncselekmény gyanúja merült fel, átadták az ügyet a népügyészségnek. ${ }^{20}$ Egy 1946. január 10-i jelentés szerint 42136 igazoló eljárásból a bizottságok 37 351-ben igazolták az illetőt, 4785 alkalommal nem. Ebböl 825 esetből állásvesztés, 264 esetben nyugdíjazás volt a büntetés, 63 esetben pedig a népügyészséghez fordultak.

A kormány többször kapott a parlamenttől különleges felhatalmazást (1946. évi VI. és XVI. törvény; 1947. évi II. és VII. törvény). Ennek értelmében a minisztertanács magánjogi, büntetőjogi, közigazgatási és a törvényhozás hatáskörébe tartozó minden kérdésben - saját hatáskörben - rendeletet alkothatott a költségvetési és a gazdasági egyensúly biztosításának érdekében. A miniszterelnöki pozíciót az államfővé választott Tildy Zoltán (1945. november 15. - 1946. február 4.) és az emigrációba kényszerített Nagy Ferenc (1945. február 4. - 1947. május 31.) után két baloldali kisgazda - és kommunista befolyás alatt álló - politikus töltötte be: Dinnyés Lajos (1947. május 31. 1948. december 10.) és Dobi István (1948. december 10. - 1952. augusztus 14.). ${ }^{21}$

A bírósági szervezet a hagyományos - világháború előtti - struktúrát követte. A kisebbnek gondolt bünügyekben és a 3000 pengő érték alatti vagyonjogi perekben járásbíróságok voltak illetékesek (ezekből 114 müködött az országban). Ezek

\footnotetext{
${ }^{20}$ Papp Gyula: Az igazoló eljárások és a háborús bünök megtorlása 1945 után Magyarországon. Aetas, 24 (2009) 2. sz. 162-179

${ }^{21}$ Vö. Haas György: Diktatúrák árnyékában. Tildy Zoltán élete. Budapest, 2000. 8-120., Szakács Sándor: Nagy Ferenc. In: Nagy Ferenc miniszterelnök. Szerk. Csicsery-Rónay. Budapest, 1995. 35-43., Somlyai Magda: Dinnyés Lajos. In: Politikuspályák. Szerk. Sánta Ilona. Budapest, 1984. 257-266., Dancs József: Dobi István. In: Politikuspályák. Szerk. Sánta Ilona. Budapest, 1984. 100-112. 233-243.
} 
feljebbviteli fórumai, valamint a nagyobb bünügyek és 3000 pengő érték fölötti polgári perek esetében illetékesek a háromtagú törvényszékek voltak (ezek száma 24 volt). Szintén háromtagú tanácsa volt az öt ítélőtáblának: Budapesten, Pécsett, Győrött, Szegeden, Debrecenben. A bírósági hálózat és a jogszolgáltatási hierarchia csúcsán az öttagú Kúria állt. A bíróságok előtt a vádat az igazságügy-minisztérium alá tartozó államügyészségek, illetve fóállamügyészségek képviselték, amelyek rendszerének legfelsőbb szintjét a Legfőbb Államügyészség (1945 nyaráig Koronaügyészség) képviselte.

Sajátos funkció jutott az 1945 utáni igazságszolgáltatási rendszerben a népbíróságoknak és népügyészségeknek. A Szovjetunióval és a szövetséges hatalmakkal kötött fegyverszüneti egyezmény 14. pontja - de már a Magyar Nemzeti Függetlenségi Front programja is - leszögezte, hogy a hazaárulók és háborús bünösök megbüntetésére népbíróságokat szerveznek. Erről a kérdésről az Ideiglenes Nemzeti Kormány 81/1945. M. E. számú rendelete határozott, amely a háborús és népellenes bünösök ügyét kivonta a területileg illetékes - a kommunisták és a SZEB által politikailag megbízhatatlannak ítélt - bíróságok hatásköre alól. A rendelet kimondta, hogy ezeket a bünöket akkor is meg kell torolni, ha azok elkövetésük időpontjában nem ütköztek jogszabályba, vagy éppen azok végrehajtására irányultak. A polgári személyeken kívül a közhivatalnokok, a fegyveres erök, a rendőrség és a csendőrség embereit is a rendelet hatálya alá helyezték. ${ }^{22}$

A népbíróságokat a törvényszéki központokban állították fel, országszerte 24 müködött különböző időintervallumban ugyan, de 1950 áprilisáig. A népbíróságnak öt laikus tagja volt, akiket az öt koalíciós párt jelölt e tisztségre. Melléjük az igazságügyminiszter rendelt ki jogvégzett tanácsvezető bírót. A vádat a népügyész képviselte, aki felkészült, felsőbb jogi képesítéssel rendelkező szakember volt. Az igazságügyminiszter nevezte ki a helyi nemzeti bizottság javaslata alapján. A népügyészek függetlenségére a kormányzat sokat adott, ezért kiemelkedően magas fizetésük volt, és állásukból bármikor elbocsáthatták őket. A népbírósági ítéletek ellen a Népbíróságok Országos Tanácsához lehetett fellebbezni, amelynek öt tagja ügyvédi vagy bírói vizsgával bíró jogász volt. Előtte a vádat a népföügyész, vagy helyettese képviselte. ${ }^{23}$

\footnotetext{
22 Palasik Mária: A jogállam megteremtésének kísérlete és kudarca Magyarországon. 1944-1949. Budapest, 2000. 21-79.

${ }^{23}$ Lukács Tibor: A magyar népbírósági jog és a népbíróságok. 1945-1950. Budapest, 1979. (a továbbiakban: Lukács Tibor, 1979) 283-262.
} 
1945 áprilisában - az MKP nyomására - a népbíróságok taglétszámát hatra emelték, s a szakszervezetek is jelölhettek tagot a testületbe. Ezzel tovább erősödött a népbíróságokban a baloldali befolyás, és ez a döntésekre is kihatott. Az ítéleteknek széles skálája volt: a halálbüntetéstől a különböző időtartamú fegyház- és börtönbüntetéseken keresztül a kényszermunkáig és az internálásig. 1945 és 1950 között 58629 fő állt a népbíróságok előtt, akik közül 477-et ítéltek, de végre csak 189-es hajtottak. Ilyen jellegü népi igazságszolgáltató testületek az összes kelet-európai országban müködtek, de Franciaországban is hasonló szervek ítélkeztek a kollaboránsok felett. Súlyos problémája azonban müködésüknek, hogy legtöbbször a személyes sérelmek, a helyi ellentétek és az egyéni érdekek, bosszúvágyak kerültek előtérbe, s nem a jogi szemlélet és az igazságszolgáltatás igénye. ${ }^{24}$

1945. március 17-én az Ideiglenes Nemzeti Kormány 60/1945. M. E. számú rendeletével - amelyet az Ideiglenes Nemzetgyülés az 1945. évi VI. törvény becikkelyezésével kodifikált - határozott a fölosztásról. Prioritásként a napszámosok, mezőgazdasági cselédek, nagycsaládos szegényparasztok és törpebirtokosok földhöz juttatását jelölte meg. Országszerte mintegy 3200 földigénylö, illetve földosztó bizottság müködött, közel 35000 taggal. Munkájukat a Veres Péter elnökletével megalakult Országos Földbirtokrendező Tanács koordinálta. A rendelet végrehajtását elsősorban a kereskedelmi és banktőke birtokainak, az 1000 hold feletti nagybirtokoknak és a nyilas, szélsőjobboldal vezetők és háborús bűnösök földjeinek a terhére képzelték el. De az 1000 hold alatti birtokból is vettek el: az úri birtok 100 holdig, a paraszti birtok 200 holdig maradhatott tulajdonosánál, de ha tudta igazolni antifasiszta tevékenyégét, akkor 300 hold földet is megtarthatott. A fölreform során 3,2 millió hold földet osztottak szét 642000 igénylő között. Ezzel a föld nélküli és az egy hold alatti földdel rendelkező agrárnépesség aránya 17\%-ra csökkent (az 1941-es 46\%ról). ${ }^{25}$

A kommunista erőkoncentráció része volt a gazdasági csúcsszerv, a Gazdasági Főtanács 1945. decemberi létrehozása is. A három főből álló testület tagja a miniszterelnök (Tildy Zoltán), az iparügyi miniszter (Bán Antal) és a közlekedésügyi miniszter (Gerő Ernő) volt. Hatáskörébe tartozott a pénz- és anyaggazdálkodás irányítása mellett az árak és bérek szabályozása is. A Gazdasági Főtanács operatív

\footnotetext{
${ }^{24}$ Lukács Tibor, 1979. 426-452.

${ }^{25}$ Lásd bővebben: Donáth Ferenc: Demokratikus földreform Magyarországon. 1945-1947. Budapest, 1969. 51-292.
} 
szerve a Titkárság volt, amelynek vezetését a - szintén kommunista párti - Vas Zoltán látta el.

A gazdasági uniformizálás jegyében, a kompetitív és szabadon működő piac helyett a kommunista dominancia alatt álló politikai vezetés - szovjet totalitárius mintára - a tervgazdálkodás bevezetését határozta el. 1947. június 11-én a kormány megszervezte az Országos Tervhivatalt. Ennek a szervezetnek a feladata volt az 1947 és 1949 közötti időszak központi gazdasági - és újjáépítési - programjának a koordinálása. Mivel ekkorra az államosítások következtében az állami szektor egyre nagyobb teret kapott a gazdasági életben, a Tervhivatal évekre és vállalati szintre lebontva határozta meg és csoportosította a feladatokat és az erőforrásokat. Teljesítési zavar vagy hiányosság esetén lehetősége volt módosítani a tervet. Működése eredményezte az állami és vállalati bürokrácia óriásivá és áttekinthetetlenné duzzadását. Az Országos Tervhivatal első elnöke - 1947 és 1949 között - a szociáldemokrata Vajda Imre volt, helyettese a kommunista párti Berei Andor. 1949-ben Vas Zoltán vette át a vezetését. ${ }^{26}$

1946-ban államosították szénbányákat (1946. évi XIII. törvény) és a legnagyobb nehézipari vállalatokat. 1948. március 25-én állami tulajdonba vették a száz főnél több alkalmazottat foglalkoztató gyárakat és üzemeket. Ezzel 1948-ra - a politikai és gazdasági fordulat évére - a bányaiparban és a nehéziparban dolgozó munkásság 90\%a, a könnyüipari munkásságnak pedig 75\%-a az állami szektorba került. 1947-ben megszüntették a régi, hagyományos kétszintű bankrendszert, s a Magyar Nemzeti Bank jegybank funkciója mellett - fiókhálózatot kiépítve - kereskedelmi bankként is müködött. A tradicionálisan meghatározó bankok is állami tulajdonba kerültek, és egyegy speciális terület financiális hátterének a biztosítására rendelték őket. Így lett a Magyar Általános Hitelbankból Beruházási Bank, a Pesti Magyar Kereskedelmi Bankból Külkereskedelmi Bank. A fejlett és kiterjedt hálózattal rendelkező vidéki hitelintézetek összevonásával hozták létre az Országos Takarékpénztárat 1949-ben. ${ }^{27}$

\footnotetext{
${ }^{26}$ Berend T. Iván: A szocialista gazdaság története Magyarországon. 1945-1968. Budapest, 1976. 7-90.

27 Botos János: A Magyar Nemzeti Bank a koalíció éveiben. 1944-1948. In: A Magyar Nemzeti Bank története. 2. köt. Szerk. Bácskai Tamás. Budapest, 1999. 299-380.
} 


\section{2. A politikai élet főbb tendenciái}

A koalíciós éveknek informális politikai intézménye a pártközi értekezlet. A pártközi értekezleteken a négy koalíciós párt vezetői vettek részt, de számos esetben meghívták a tanácskozásra a PDP és az MRP képviselőit, valamint a kormány és az Ideiglenes Nemzetgyülés Elnökségének tagjait. Nemegyszer a miniszterelnök kezdeményezte összehívását. A pártközi értekezlet célja az volt, hogy a koalíciós pártok belső fórumon, egymás között - nem a nyilvánosság elött, pártsajtójukon keresztül vitassák meg a felmerülő nézetkülönbségeket s határozzák meg együtt a közös politikai stratégiát. Ebböl a szempontból az Ideiglenes Nemzeti Kormány időszakában különleges helyzet állt elő, a kormánynak ugyanis nem volt ellenzéke, s a kormánytagok mind nemzetgyülési képviselök voltak, ezáltal pedig a törvényhozás és a végrehajtás - a hatalommegosztás klasszikus elvei szerint - nem vált el egymástól. Bonyolította a dolgot, hogy a politikai ügyekben illetékes népbíróságok is pártalapon szerveződtek, ezzel a bírói hatalom függetlensége is odalett.

A pártközi értekezleteken alapkérdésekben nem voltak viták. A Magyar Nemzeti Függetlenségi frontba tömörül pártok egyetértettek abban, hogy meg kell szüntetni az ország hadiállapotát, le kell számolni a fasizmussal, meg kell valósítani a földreformot, ki kell építeni a minél szélesebb demokráciát, újjá kell építeni az országot, felelősségre kell vonni a háborús bünösöket. Az MNFF kormánypozíciójának megszünte és a nemzetgyülési választások után is megmaradt a helye a koalíciós egyeztetésnek a politikai életben. Pártközi értekezletekre 1945 novembere és 1949. május 15. között ameddig hivatalosan létezett a koalíció - rendszeresen sor került. ${ }^{28}$

Hosszú tárgyalások után a magyar állam és a világháborúban győztes szövetséges hatalmak közötti békekötésre 1947. február 10-én Párizsban került sor. Ezt a magyar nemzetgyülés 1947. július 16-án iktatta be törvényei közé (1947. évi XVIII. tc.) Így Magyarország nemzetközi jogi értelemben ismét szuverén, független állam lett. A SZEB mandátuma ugyan lejárt, az országban mégis maradt 50000 szovjet katona

\footnotetext{
${ }^{28}$ Pártközi értekezletek. Politikai érdekegyeztetés, politikai konfrontáció. 1944-1948. S. a. r., jegyz.: Horváth Julianna, Szabó Éva, Szűcs László, Zalai Katalin. Budapest, 2003. (a továbbaban: PÉ, 2003) Bevezetö: VII-XXI.
} 
maradt, hogy biztosítsák az összeköttetést a megszállt Ausztriában állomásozó és a Szovjetunió között. Ekkor Magyarország kérte felvételét az Egyesült Nemzetek Szervezetébe, de ezt a Biztonsági Tanács elutasította. ${ }^{29}$

1946. március 5-én - az MKP, az SZDP, az NPP és a szakszervezetek részvételével - létrejött a Baloldali Blokk. Ez a koalíció végleges és jelképértékü polarizálódásának a jele volt. Egyértelművé vált, hogy a kisgazdapárt képviselte polgári értékekkel a baloldali pártok nem értenek egyet. Követelésük volt az FKGP jobbszárnyának eltávolítása, azaz a „nép ellenségeinek” kiszorítása a politikából, gyakorlatilag azonban a legnagyobb kormánypárt mielőbbi megosztása és felszeletelése volt a cél, amelyet a pártban tevékenykedő kriptokommunisták (Ortutay Gyula, Dobi István) munkája is segített. ${ }^{30}$ Nem sokkal később a kényszerhelyzetben lévő kisgazda elnökség kizárta húsz nemzetgyülési képviselőjét a pártból és a frakcióból. 1947. február 25-én a párt főtitkárát, Kovács Bélát elrabolták és a Szovjetunióba hurcolták. ${ }^{31}$ Az ez elleni határozott kormánypárti fellépés és tiltakozás elmaradására reagálva Pfeiffer Zoltán - csaknem félszáz hívével - kilépett a kisgazda képviselőcsoportból.

A kisgazdapárt szétzúzása mellett az MKP a baloldalon belül is hegemóniára törekedett. 1948. június 12-én a SZDP és az MKP - a 149 szociáldemokrata küldött és 294 kommunista párti delegált részvételével tartott közös kongresszuson - kimondta az egyesülést. A valóságban ez azt jelentette, hogy kommunisták magukba olvasztották a szociáldemokraták bal szárnyát (miután az európai szociáldemokrata tradíciókhoz ragaszkodókat eltávolították a szervezetből). Másnap, 1948. június 13-án tartotta első kongresszusát a Magyar Dolgozók Pártja, amelynek elnökévé Szakasits Árpádot, főtitkárává Rákosi Mátyást, helyetteseivé pedig Farkas Mihályt, Kádár Jánost és Marosán Györgyöt választották. (Ugyanígy, az egységesülés jegyében jött létre a politikai pártok nő- és ifjúsági szervezeteinek egyesülése révén a Magyar Nők Demokratikus Szövetsége [vezetője Rajk Lászlóné volt] és a Magyar Ifjúság Népi Szövetsége [elnöke Nonn György volt]. Mindkét szervezet vezetője eredetileg a kommunista párt tagja volt.) ${ }^{32}$

\footnotetext{
${ }^{29}$ Romsics Ignác: Az 1947-es párizsi békeszerződés. Budapest, 2006. 189-246.

${ }^{30}$ Balogh Sándor: Parlamenti és pártharcok Magyarországon. 1945-1947. Budapest, 1975. 175-195.

${ }^{31}$ Palasik Mária: Kovács Béla. 1908-1959. Budapest, 2002. 49-85.

${ }^{32}$ Vö. Rákosi Sándor: Az MKP és az MDP szervezeti felépítése. 1944-1956. Budapest, 1968. 7-65. és Kádár Zsuzsanna: Az SZDP beolvasztása. In: Fordulat a világban és Magyarországon. Szerk. Feitl István, Izsák Lajos, Székely Gábor. Budapest, 2000. 271-280.
} 
Az országban tevékenykedő legnagyobb és legheterogénebb politikai szervezet, az igazi nagy gyüjtőpártnak tekinthető Független Kisgazda-, Földmunkás és Polgári Párt volt. Egyesíteni tudta, összefogta a polgári tábort, benne éppúgy megtalálták a maguk értékeit és érdeket a néhány holdas újgazdák, mint a városi kishivatalnokok, kiskereskedők és a nagypolgárok. A párt legerősebb csoportja a Nagy Ferenc, Kovács Béla és Varga Béla nevével fémjelzett centrum volt. A párt jobboldalát Sulyok Dezső, Pfeiffer Zoltán, Vásáry István képviselték, míg a baloldalon Dinnyés Lajost, Dobi Istvánt, Ortutay Gyulát találjuk, akik később - nyíltan is - a kommunistákhoz pártoltak. A pártnak a nemzetgyülési választások előtt 900000 tagja volt, lapja Kis Újság címmel jelent meg. ${ }^{33}$

A Magyar Kommunista Párt az ipari munkásság és a szegény városi réteg szavazatira támaszkodhatott a választásokon. Taglétszáma progresszíven emelkedett, s 1945 őszére elérte az 500000 főt, lapja a Szabad Nép volt. A pártvezetésben a moszkvai emigrációból hazatért vezetők (Rákosi Mátyás, Nagy Imre, Vas Zoltán, Révai József) éppúgy szerephez jutottak, mint a magyarországi illegális mozgalmat irányító (Rajk László, Kádár János, Apró Antal, Kállai Gyula) politikusok. ${ }^{34}$ A 400 000-res taglétszámmal bíró, és a Népszavát kiadó Szociáldemokrata Párt a munkásságon kívül a kishivatalnokok és kispolgárok rétegének egy részét tudhatta maga mellett. A pártvezetésben eleinte a baloldaliak (Szakasits Árpád, Marosán György, Rónai Sándor) kisebbségben maradtak az európai szociáldemokrata hagyományokat követő politikusokkal (Peyer Károly, Kéthly Anna, Bán Antal) szemben. A radikálisan baloldali és a nincstelen szegényparasztokat megcélzó Nemzeti Parasztpárt vezetői a népi írók szellemi mozgalmából kerültek ki (Veres Péter, Kovács Imre, Illyés Gyula, Erdei Ferenc), de ebben a szervezetben tevékenykedett a később nagyhatású jogfilozófus Bibó István is. A párt lapja a Szabad Szó volt. ${ }^{35}$

A kisebb baloldali pártok közül a Polgári Demokrata Párt és a Magyar Radikális Párt (MRP) indult az 1945-ös nemzetgyülési választásokon. A Teleki Géza vezette, 70 000 fős tagsággal rendelkező PDP lapja a Supka Géza szerkesztésében megjelenő Világ

\footnotetext{
${ }^{33}$ Vida István: A Független Kisgazdapárt politikája. 1944-1949. Budapest, 1976. (a továbbiakban: Vida István, 1976) 31-123.

${ }^{34}$ Izsák Lajos: A koalíció évei Magyarországon. 1944-1948. Budapest, 1986. 25-65.

35 Tóth István: A Nemzeti Parasztpárt története. 1944-1948. Budapest, 1972. 69-210.
} 
volt. Az MRP meghatározó politikusa Csécsy Imre és Zsolt Béla volt, lapja a Haladás. ${ }^{36}$ A Demokrata Néppárt (DNP) névre két igény is érkezett a SZEB-hez, amely végül a baloldalibbnak vélt Barankovics Istvánnak adta meg a DNP létrehozására az engedélyt, elutasítva Pálffy József gróf kérését. A párt már nem tudott szervezőmunkát végezni, így a választáson nem vett részt, $\mathrm{s}$ az FKGP - amellyel választási megállapodást kötött - támogatására buzdította szimpatizánsait. Az új nemzetgyülésben ennek értelmében ketten képviselték a DNP-t, kilépve a kisgazda képviselőcsoportból. ${ }^{37}$

A nemzetgyülési választások főpróbájaként tartották a budapesti törvényhatósági választásokat 1945. október 7-én. A választásra jogosultak valamivel több mint 90\%-a élt szavazójogával. Az eredmény abszolút győzelmet hozott a kisgazdapártnak, amely megszerezte a szavazatok 50,54\%-át. A Dolgozók Egységfrontjának - az MKP és a szociáldemokraták közös listája - az eredménye 42,76\% volt. 1945 októberében Vorosilov marsallnak, a SZEB elnökének a közremüködésével pártközi értekezletet tartottak, amelynek témája az volt, hogy az MNFF-be tömörült politikai szervezetek egységes, közös listán induljanak, s a mandátumokat előzetes tárgyalásokon osszák el egymás között. A fogadtatás vegyes volt, végül azonban a terv meghiúsult. Az Egyesült Államok és Nagy-Britannia kormánya ugyanis közölte a magyar politikai vezetőkkel, hogy az ország kormányának diplomáciai elismerésének elengedhetetlen feltétele a közös listáról való lemondás. ${ }^{38}$

Az 1945. november 4-i nemzetgyülési választásokon a szavazópolgárok 92,4\%-a (4 774653 fö) jelent meg, akik közül 4730 409-en adtak le érvényes szavazatot. A kisgazdapárt az országos választáson is megszerezte az abszolút többséget, mégis Vorosilov nyomására - fennmaradt a koalíciós kormány. Sőt, a kommunistáknak azt is sikerült keresztülvinniük, hogy az 1945. november 15-én megalakult Tildy Zoltán vezette kormányban a győztes kisgazdák hét, míg a baloldali pártok szintén hét tárcát kapjanak (MKP: 3, SZDP: 3, NPP: 1), köztük az MKP olyan jelentőset, mint a rendőrség és közigazgatás feletti ellenőrzést biztosító - belügyminisztérium. ${ }^{39}$

\footnotetext{
${ }^{36}$ Izsák Lajos: Polgári ellenzéki pártok Magyarországon. 1944-1949. Budapest, 1982. (a továbbiakban: Izsák Lajos, 1982) 11-43.

${ }^{37}$ Izsák Lajos: A Keresztény Demokrata Néppárt és a Demokrata Néppárt. Budapest, 1985.

38 Ignácz Károly: Az 1945. évi választások Budapesten. In: Tiltott történelmünk 1945-1947. Szerk. Horváth János. Budapest, 2006. 44-55.

39 Balogh Sándor: Választások Magyarországon. 1945. A fővárosi törvényhatósági és a nemzetgyűlési választások. Budapest, 1984. 31-170.
} 
1945. december 7-én, első ülésén a nemzetgyülés elfogadta az ideiglenes házszabályt, amelyet aztán a végleges követett 1946. január 25-én. A házszabály meghatározta a mandátumvizsgáló bizottság munkáját, a megbízólevelek átadásának és a megalakulásnak a menetét. Rendelkezett a nemzetgyülés elnökének jogköréröl, amelynek egyik legfontosabb eleme volt, hogy a házelnök saját hatáskörben összehívhatta a parlamentet. Szabályozta a bizottságok müködését, amelyek közül legmeghatározóbb a Politikai Bizottság volt. A köztársasági elnöknek, a miniszterelnöknek és a kormánytagoknak ugyanis részt kellett venni egy Politikai Bizottsági meghallgatáson, amelynek tagjai döntöttek a jelölt alkalmasságáról és javasolták - vagy éppen elutasították - a kinevezését. A parlamentben heti egy interpellációs nap állt a képviselők rendelkezésére, ahol kérdéseket intézhettek a kormány tagjaihoz. A miniszter válaszolhatott szóban, harminc napon belül írásban, de meg is tagadhatta a válaszadást. A nemzetgyülés ülései nyilvánosak voltak, de a kormánytagok kérésére a házelnök zárt ülést is elrendelhetett. 1945 és 1949 között a nemzetgyülés évente átlagosan 70 napot ülésezett, 19 állandó bizottságot müködtetett és 152 törvényt alkotott.

Az 1947. július 27-én elfogadott 1945. évi XXII. törvény nem jelentett új törvényt, csupán az 1945-ös választójogi törvény pontosítását, novelláris kiegészítését tartalmazta. Titkos, egyenlő, általános és közvetlen maradt a választás, változatlan maradt a választókerületi beosztás és a lajstromos rendszer is. A törvényhozás nevét országgyülésre változtatták, és hangsúlyozták egykamarás voltát. Minden 14000 szavazat ért egy parlamenti mandátumot és az országos listáról betölthető képviselői helyek számát ötvenről hatvanra emelték. Prémiumos rendszert vezettek be, amelynek értelmében a koalíció 60\%-os választási eredménnyel az országos listás helyek $80 \%$-át, míg 75\%-os eredmény esetén az összes így megszerezhető mandátumot elnyerheti. Megszünt az a lehetőség, hogy a parlament újabb képviselőket válasszon. Nem szavazhattak a B-listázottak, a Csehszlovákiából kitelepített magyarok, volt viszont választójoga a kitelepülni szándékozó szlovákoknak. A választhatók körét tovább szükítve a Horthy-korszak több mint harminc - a törvényben felsorolt - szervezetében tagságot vállalókat, vagy a régi kormánypártok helyi vezetőit, választmányi tagjait, képviselőjelöltjeit nem illette meg a választójog. Ezzel az 1945-öshöz képest 10\%-kal csökkent a választópolgárok száma.

A kommunistáknak a kisgazdapárt felszámolását - de legalábbis pozícióinak gyengítését - célzó szalámipolitikájának egyik eseménye volt, hogy a párt 
jobbszárnyához tartozó húsz képviselőt kizártak a frakcióból. Ezek a politikusok Sulyok Dezső vezetésével megszervezték a Magyar Szabadság Pártot, amely azonban nem kapott müködési engedélyt, így hosszú ideig nemzetgyülési szervezetként tevékenykedett. ${ }^{40} 1946$ novemberében indította meg a tagszervezés munkáját, az 1947es országgyülési választásokon azonban már nem indult, mivel elnöke és több vezetője elvesztette választójogát. ${ }^{41}$ A kormánypártokon kívül több - magát ellenzékinek nevező párt - szállt versenybe a szavazatokért és a mandátumokért. Erős politikai tábort tudhatott magának az FKGP-böl - ötven képviselö élén - kivált Pfeiffer Zoltán vezette Magyar Függetlenségi Párt (MFP). ${ }^{42}$ De az 1945 óta fokozatosan szerveződő és erősödő Demokrata Néppárt - amelynek Barankovics István volt az elnöke - is számíthatott a koalícióból kiábrándult polgárok voksára.

A kisebb ellenzéki pártok közül a parlamenti Polgári Demokrata Párt mellett a Peyer Károllyal és az áltata irányított kis létszámú független szociáldemokrata csoporttal kiegészült - Magyar Radikális Párt is indult a választásokon. A keresztény radikalizmus és a politikai katolicizmus hívei a - Katolikus Néppárttal fuzionált Keresztény Női Tábort (KNT) támogathatták, amelyet a szerzetesnővér Slachta Margit - az első női parlamenti képviselő - vezetett. Érdekes szerepe volt a Független Magyar Demokrata Pártnak (FMDP), amely magát, mint az 1945-ös kisgazdapárt értékeinek és hagyományainak letéteményesét határozta meg. Elnöke, az egykori miniszterelnökségi államtitkár Balogh István ugyan polgári és konzervatív értékekkel kampányolt, mégis a kormány lojális ellenzékének szerepét szánta szervezetének.

$\mathrm{Az}$ 1947-es választást beárnyékolta, hogy a kommunisták - a törvénymódosítások útján megvalósított szavazatcsökkentő taktikájuk mellett szervezett választási csalást is elkövettek. Annak ugyanis, aki tudta, hogy a választás napján nem fog a lakóhelyén tartózkodni, a helyi választási bizottság egy választói névjegyzék-kivonatot adott ki, amely igazolta, hogy joga van szavazni, és ezt az ország bármelyik szavazókörében megteheti. Ezekkel a - többször is felhasznált - „kék

\footnotetext{
${ }^{40}$ Izsák Lajos, 1982. 117-180.

${ }^{41}$.Szerencsés Károly: A nemzeti demokráciáért. Sulyok Dezső. Pápa, 1997. 211-233.

${ }^{42}$ Földesi Margit - Szerencsés Károly: A megbélyegzés hatalma. Pfeiffer Zoltán. 1900-1981. Budapest, 2003. 161-235.
} 
cédulákkal" - Péter Gábor bizalmas jelentése szerint - 62000 szavazatot adtak le szervezetten az MKP-ra. ${ }^{43}$

Az ellenzék megrendszabályozására tett első lépés az MFP 49 mandátumának a Választási Bíróság által történt megsemmisítése volt, ami után nem sokkal Rajk László belügyminiszter fel is oszlatta a politikai szervezetet. Ez a helyzet a DNP-t is passzivitásra kényszerítette, és hosszú agónia után 1949. február 4-én - miután elnöke külföldre szökött - kimondta feloszlását. Slachta Margit ugyancsak a nyugati emigrációt volt kénytelen választani. A baloldali egység - a Magyar Dolgozók Pártjának (MDP) 1948-as létrejötte után a kommunisták ismét a népfontpolitikát hirdették meg. Az 1949. május 15-én tartott országgyűlési választásokon már csak egy szervezet - a Magyar Függetlenségi Népfront (MFNF) - listájára lehetett szavazni. A szavazópolgárok 96,04\%-a járult az urnákhoz, akiknek 96,27\%-a támogatta a népfront jelöltjeit. Ezzel a parlament látszatparlamentté és a kommunisták szavazógépezetévé, a plurálisnak induló demokrácia pedig látszatdemokráciává vált.

Az diktatúra kiépítésének egyik utolsó állomása - a politikai pluralizmus teljes korlátozása után - a népfronthagyományok felélesztése volt. 1949. február 1-jén megalakult a Magyar Függetlenségi Népfront. Elnöke Rákosi Mátyás, alelnöke Dobi István és Erdei Ferenc, főtitkára pedig Rajk László lett. ${ }^{44}$ Tagszervezetei először a kormánypártok, az MDP, az FKGP és az NPP voltak. Nemsokára csatlakozott azonban a - már korábban fuzionált - Polgári Demokrata Párt és Magyar Radikális Párt szövetsége, valamint a Független Magyar Demokrata Párt. Ezzel véglegesen biztosítva volt a - kommunista ellenőrzésü - politikai egyveretüség. Az 1949. évi országgyülési választásokon már csak az MFNF listájára lehetett szavazni, nem volt választás

\footnotetext{
${ }^{43}$ Földesi Margit - Szerencsés Károly: Halványkék választás. Magyarország - 1947. Budapest, 2001. 268-269.

${ }^{44}$ Pintér István - Szabó Bálint: A népfrontmozgalom Magyarországon. Történeti áttekintés. Budapest, 1978. 173-215.
} 


\section{A SZEGEDI ÉVEK}

\section{1. Családja, tanulóévei}

Balogh István 1894. március 30-án született a Krassó-Szörény vármegyei Stájerlakon (ma Anina, Románia).

A település két részből állt. Az 1770-es években odaköltözött stájer favágók alapította Stájerlakból - amelyet nem sokkal később (mivel első lakói a török veszély elöl elmenekültek), 1790-ben német telepesekkel újra kellett telepíteni -, valamint az 1846-ban alapított Aninából, ahol feketeszénbánya és szénelőkészítő üzem müködött. Az évi termelés mennyisége 1882-ben: nyersvas 52341 mázsa (193 662 forint érték), öntött nyersvas 30753 mázsa (113786 forint érték), feketeszén 1801400 mázsa (1 134882 forint érték), szénvaskő 19212 mázsa (14 793 forint érték). ${ }^{45}$

Stájerlak tehát - vagy ahogy később nevezték Stájerlakanina - fontos bányászvárosa, valamint vasúti és postai csomópontja volt a dualizmus kori Magyarországnak. 1910-ben 12336 lakosa közül 8837 német (71,63\%), 1280 román (10,37\%), 705 magyar (5,71\%) és 564 szlovák (4,57\%) volt. 1776-ban alapított katolikus plébániája a csanádi egyházmegye oravicai esperesi kerületéhez tartozott. A Szentháromság tiszteletére szentelt temploma 1872-ben készült el. ${ }^{46}$

Balogh István édesanyja Nottny Teréz, édesapja Balogh László. ${ }^{47}$ A család zsidó származású, eredeti vezetéknevük Bloch - más forrás szerint Blech - volt. ${ }^{48}$ Balogh Istvánnak egy öccse volt, Balogh János, aki fiatalon meghalt, s egy kislánya született: Balogh Viola (férjezett nevén Berkes Illésné).

\footnotetext{
${ }^{45}$ Pallas Nagy Lexikona. 1. köt. Budapest, 1893. 672

${ }^{46}$ Magyar Katolikus Lexikon. 12. köt. Budapest, 2007. 323.

47 Budapest Főváros Levéltára (a továbbiakban: BFL). Állami anyakönyvi másodpéldányok levéltári gyüjteménye. XXXIII. 1. a. (a továbbiakban: XXXIII. 1. a.) 42. köt. Budapest, II. ker. 1976. Halotti anyakönyv [856-1700]. 1006.

${ }^{48}$ M. Kiss József - Szabó Róbert, 2005. 30.
} 
Balogh István édesapja 1898-ban elhunyt. Visszaemlékezései szerint semmilyen személyes élménye vagy emléke nem volt apjáról. (Édesanyja később házasságot kötött jobaházi Dőry Ádámmal.)

A kisgyermek Balogh tízévesen a nagyszombati érseki árvaházba és líceumba került. Elemi iskolai tanulmányait ugyan még Stájerlakon folytatta, a gimnázium nyolc osztályát viszont már Nagyszombatban végezte, az utolsó négy évet kisszeminaristaként. A nagyszombati katolikus diákközösséget kiváló képességü és összetartó csoportként ismerte meg. 1912-ben érettségizett. ${ }^{49}$

Mint kisszeminarista a nyári szünidőket otthon töltötte, megismerve a sokvallású (katolikus, ortodox, evangélikus, református, izraelita) és többnemzetiségü, széttagolt fekvésü hegyi település lelkipásztori ellátásnak problémáit. Naponta ministrált, illetve gyakran helyettesítette a kántort.

Balogh István édesanyja időközben Budapestre került, ahol a parlamentben volt ruhatáros. Így a fiatal Balogh gyakran bejárt a törvényhozás épületébe, s a karzatról érdeklődve figyelte a politikai vitákat. Kedvenc politikusa Rakovszky István és Apponyi Albert gróf volt. ${ }^{50}$

Balogh István a nagyszombati évek hatására választotta a papi hivatást, s noha édesanyjának is az volt az álma, hogy fiából pap legyen, Baloghot nem kellett rábeszélni az egyházi pályára. Az esztergomi szemináriumban kezdte meg tanulmányait, ám alig egy hónappal a tanév megkezdése után súlyos látászavarai lettek. Az orvos szemidegsorvadást állapított meg, s eltanácsolta mind a tanulástól, mint a papi szolgálattól. A diagnózis téves volt, ugyanis Balogh szaruhártya-gyulladás miatt jelentkező szaruhártyahomályban szenvedett.

Mivel az esztergomi szemináriumból kimaradt, de továbbra is pap szeretett volna lenni édesanyja közbenjárt érdekében Siegescu Józsefnél (1873-1931). Siegescu (görög katolikus pap, a Központi Papnevelő Intézet tanára, a budapesti egyetem román nyelv és irodalom professzora) Krassó-Szörény vármegye oravicai választókerületének - amelyhez egyénként Stájerlakanina is tartozott - volt az országgyülési képviselője, s

\footnotetext{
${ }^{49}$ Balogh István visszaemlékezései. [Kézirat Borovi József hagyatékából.] A Magyar Egyháztörténeti Enciklopédia Munkaközösség tulajdonában. (a továbbiakban: BIV) Ennek egy rövidebb - mellékletek nélküli - változata megtalálható a Politikatörténeti és Szakszervezeti Levéltárban: PIL 867. f. H-b-286. Klettner Csilla tanulmányában erre hivatkozik.

${ }^{50} \mathrm{BIV}$
} 
Balogh édesanyja ismerte a parlamentből. ${ }^{51}$ Siegescu József jó barátságban volt Glattfelder Gyula (1874-1943) csanádi püspökkel, aki kérésére föl is vette Baloghot a csanádi papneveldébe. ${ }^{52}$

Teológiai tanulmányait Balogh tehát Temesvárott folytatta. Spirituálisa Fiedler István (1871-1957) későbbi szatmári püspök (1930-1939) volt. Kedves tanára volt Kovács István (1880-1948) későbbi nagybecskereki plébános, a csanádi egyházmegyének a délszláv államhoz került része apostoli kormányzója, valamint Glattfelder, aki a kánonjogot és az egyháztörténetet oktatta. ${ }^{53}$

Balogh Istvánt Glattfelder Gyula püspök 1918. június 16-án szentelte pappá a temesvári székesegyházban. Első állomáshelyei az egyházmegye Romániához került részén voltak: Csákon 1918. szeptember 1. és 1920. május 1. között szolgált káplánként, Újszentannán pedig 1920. május 1-jétől 1921. április 30-ig volt segédlelkész. 1921 és 1925 között Budapesten volt hitoktató. 1925. október 29-én a budapesti egyetemen középiskolai hittanári oklevelet szerzett.

\section{Balogh István papi pályájának állomásai ${ }^{54}$}

\section{Beosztása}

\section{Segédlelkész \\ Segédlelkész}

Hitoktató

Önálló hitoktató

Segédlelkész

Plébános

Helyettes plébános

Helyettes plébános

Nyugállományban
Helye

Csák

Újszentanna

Budapest

Szeged

Szeged-Belváros

Szeged-Alsóközpont

Kemence

Budapest, Thököly út

Budapest

\section{Ideje}

1918. szeptember 1. - 1920. április 30.

1920. május 1. - 1921. április 30.

1921. május 1. - 1925. szeptember 1.

1925. szeptember 1. - 1926. augusztus 31.

1926. szeptember 1. - 1933. február 28.

1933. március 1. - 1946. március 1.

$1951-1953$

$1954-1957$

1957-tö1

\footnotetext{
${ }^{51} \mathrm{BIV}$

${ }^{52}$ Lotz Antal: Glattfelder Gyula, az egyházfő és tudós. Vigilia, 48 (1983). 2. sz. 142-143.

${ }^{53} \mathrm{BIV}$

54 Szeged-Csanádi Püspöki Levéltár (a továbbiakban: SZCSPL) Csanád egyházmegye papságának törzskönyvlapjai, 62. sz.
} 
Balogh István külsejét kezelőorvosa, Korányi András (1903-1995) a következőképpen írta le. 1933-ban, amikor megismerkedtek - Balogh ekkor harminckilenc éves - a páter százhatvannyolc centiméter magas és százharminckét kilogramm volt. „E hatalmas súlytöbblet ellenére megjelenése igen kedvező benyomást tett. Férfiarcra nem igen illő mondani, hogy »szép«, használjuk hát azt a szót, hogy »megnyerő« volt. Igen halk, mindamellett érthető, jól hallható választékos beszéde, értelmet sugárzó szemei, hófehér, ezüstös haja igen vonzóvá tették személyét. Összefoglalva abnormis kövérsége ellenére jó benyomást keltett, amit még csak fokozott ápoltsága s az igen jól szabott reverenda vagy papi civil öltözék." ${ }^{55}$

\section{2. Tudományos és egyházi kapcsolatai, doktori értekezése}

Balogh szeged-belvárosi segédlelkészként kapcsolatba került Bangha Bélával (1880-1940) is. ${ }^{56}$ A harcos szellemü jezsuita „sajtópáter” a keresztény nemzeti ideológia egyik irányzatának szellemi alapvetője volt - Magyarország újjáépitése és a kereszténység (1920) címü művével -, s évekig vezette a katolikus Központi Sajtóvállalatot. ${ }^{57}$ Amikor a szegedi szemináriumban tartott az 1920-as évek második felében lelkigyakorlatot nem a jezsuita rendházban lakott, hanem Balogh páter meghívására a szeged-belvárosi plébánián. Bangha elismerően szólt Balogh sajtószervező tevékenységéről, s megkérte, hogy állítson össze adatsort a szegedi közéleti szereplők felekezeti hovatartozásáról.

„Statisztikát akart összeállítani arról - emlékezett vissza később Balogh István -, hogy a köztisztviselői karban a protestánsok többségben vannak. Megkért, hogy Szegeden én állítsam össze. Elküldtem. Azt válaszolta: Hagyjam abba. Még Debrecenben is jobban állunk."

\footnotetext{
${ }^{55}$ Korányi András: Emléktöredékek. Budapest, 1995. (a továbbiakban: Korányi András, 1995) 323.

${ }^{56}$ Molnár Antal - Szabó Ferenc SJ: Bangha Béla SJ emlékezete. Budapest, 2010.

${ }^{57}$ Vö. Kiss Mária Rita: Bangha Béla sajtókoncepciója politológiai szempontból. In: Állam és egyház a polgári átalakulás korában Magyarországon. 1848-1918 Szerk. Sarnyai Csaba Máté. Budapest, 2000.146-156.

${ }^{58} \mathrm{BIV}$
} 
Glattfelder Gyula püspök 1929-ben Baloghot kérte meg, hogy a Szegeden - az új egyházmegyei székhelyen - elkészült püspöki palota berendezésében - szőnyegek, bútorok, festmények, órák stb. vásárlásával - legyen segítségére. Ezt Balogh el is vállalta, s a korabeli szegedi pletyka szerint a püspökség berendezésekor „mindenki jól járt, de leginkább Balogh páter". ${ }^{59}$ Állítólag később legendássá vált mügyüjteményét ekkor alapozta meg.

Szekfü Gyula (1883-1955) - a Horthy-korszak keresztény nemzeti gondolata egyik irányzatának ideológusa ${ }^{60}$, akkor a budapesti egyetem professzora, a Magyar Tudományos Akadémia levelező tagja - 1929-ben adta ki Bethlen Gábor címü könyvét. Ám a munka körül hamarosan - hasonlóan 1913-ban megjelent A számüzött Rákóczi címü kötetéhez - élénk vita alakult ki, amely nem is annyira szakmai, mint inkább szemléletbeli eltérésekre és törésvonalakra világított rá.

Szekfü Bethlen-életrajzát élesen bírálta Rugonfalvi Kiss István debreceni egyetemi tanár ${ }^{61}$, aki nem elégedett meg a Protestáns Szemle 1929. februári számában megjelent kritikája közlésével, de még abban az évben közel százharminc lapos önálló kötetet is kiadott (Az átértékelt Bethlen Gábor. Válaszul Szekfü Gyulának). Minderre Szekfü Gyula Kritika és terror címmel reagált a Magyar Kultúra hasábjain (írása később különnyomatként önállóan is megjelent). ${ }^{62}$

A vita azonban igencsak konok és személyeskedő hangvételüvé vált, s nem történeti tények és érvek mentén folyt. A katolikus Szekfü és református Rugonfalvi

59 Paskai László (*Szeged, 1927. május 8.) bíboros, kiérdemesült prímás, esztergomi érsek - aki gyermekkorát Szegeden töltötte - szóbeli közlése. 2011. április 12. Ezt erősíti meg Rosdy Pál hozzászólása Gergely Jenő előadásához. In: Gergely Jenő: A katolikus egyház Magyarországon 1944 után. Budapest, 1991. 29.

${ }^{60}$ A keresztény nemzeti gondolatról lásd bővebben: Gergely Jenő: Katolikus egyház, magyar társadalom. 1890-1950. Budapest, 1989. (a továbbiakban: Gergely Jenő, 1989) 74-100., és Gyurgyák János: Ezzé lett magyar hazátok... A magyar nemzeteszme és nacionalizmus története. Budapest, 2007. 291-385.

${ }^{61}$ Rugonfalvi Kiss István (1881-1957) bölcsészet- és jogtudományt tanult a budapesti egyetemen. 1904ben jogi doktorátus szerzett. 1906-ban Győr vármegye főlevéltárosa volt. 1914-ben debreceni egyetem professzorává nevezték ki. 1918-ban a Székely Nemzeti Tanács elnöke volt. 1931-32-es tanévben rektor. Jelentősebb művei közül: II. Rákóczi Ferenc erdélyi fejedelemmé választása. Budapest, 1906.; A magyar helytartótanács története I. Ferdinánd korában. Budapest, 1907.; Az utolsó nemesi fölkelés. 1-2. köt. Győr, 1909-1911.; Bethlen Gábor életrajza. Budapest, 1922; Az egységes magyar nemesi rend kifejlődése. Budapest, 1932.

${ }^{62}$ Szekfü Gyula: Kritika és terror. 1-2. Magyar Kultúra, 16 (1929). 1. félév. 6. sz. 251-256. és 7. sz. 300305. 
Kiss pengeváltása kapcsán a szélesebb protestáns nyilvánosságban az a kép alakult ki, hogy a katolikus történész konfesszionális alapon elfogult, s tendenciózus forráshasználatával igyekszik Bethlen alakját sötétebben ábrázolni. A felekezeti ellentéten túl ebben a vitában a Rugonfalvi Kiss által képviselt nemzeti romantikus történelemfelfogás ütközött a Szekfü Gyula által fölvállalt nyugatiasabb, szellemtörténeti alapú szemléletmóddal. ${ }^{63}$

Rugonfalvi Kiss István 1929. április 16-án este nyolc órakor Szegeden a református egyház Kálvin téri székházának tanácstermében tartott előadást Bethlen Gáborról. ${ }^{64}$ Az előadásnak - írta a Délmagyarország - ,,az a körülmény ad aktualitást, hogy nemrég jelent meg Szekfü Gyula általános feltűnést keltő Bethlen Gábor életrajza, amelyben a szerző Bethlen Gáborral is ugyanazt kísérli meg, amit már tett II. Rákóczi Ferenccel". 65

Balogh István szeged-belvárosi segédlelkész, mint a Szegedi Katholikus Tudósitó szerkesztője - a lap fejléces papírján - és mint egyházmegyei sajtóreferens 1929. április 20-án írt levelet Szekfü Gyulának, amelyben tájékoztatta a történészprofesszort arról, hogy „,a napokban városunkat szerencséltette rugonfalvi Kiss István egyetemi tanár. Szükségesnek tartotta, hogy hittestvéreinek egészen szük körében illő kritikával részesítse Méltóságod Bethlen Gáborról írott könyvét.",66

Szekfü 1929. április 26-án válaszolt Baloghnak. Megköszönte a tájékoztatást, s közölte, hogy a Rugonfalvi Kissnek írt, a Magyar Kultúrában közölt válaszának különnyomatát a kiadó eljuttatta Szegedre is ,a Corda és a Nemzeti Sajtóvállalat könyvkereskedéseibe igen olcsó áron való eladás végett”. ${ }^{67}$ (Szekfü Gyula egy rövid nyilatkozatot is mellékelt leveléhez, amelyet a szegedi sajtóban szeretett volna elhelyeztetni Balogh Istvánnal. ${ }^{68}$ )

\footnotetext{
${ }^{63}$ Vö. Erös Vilmos - Gyimesi Pálma: Ifjabb Révész Imre levelei Szekfü Gyulához (1929-1937). Lymbus, 2009. Föszerk. Ujváry Gábor. Budapest, 2009. 234-235.

${ }^{64}$ Szegedi Napló, 1929. április 16.

${ }^{65}$ Délmagyarország, 1929. április 16.

${ }^{66}$ Országos Széchényi Könyvtár Kézirattár (a továbbiakban: OSZK KT) Fond 7/90. Fol. 1.

${ }^{67}$ OSZK KT Fond 7/90. Fol. 2.

${ }^{68}$ Ezt azonban a szegedi napilapok - Szegedi Új Nemzedék, Szegedi Napló, Délmagyarország - 1929. áprilisi és májusi számaiban hiába kerestük.
} 
A Ferenc József Tudományegyetem bölcsészet-, nyelv- és történettudományi kara tanácsának 1929. évi december 19-én tartott negyedik rendes ülése 139. számú pontja az alábbi volt.

„Dr. Fógel József és dr. Erdélyi László előterjesztik véleményes jelentésüket Balogh István $\mathrm{r}$ [ómai ] $\mathrm{k}$ [atolikus]. segédlelkész bölcsészdoktori szigorlat iránti kéréséröl. ${ }^{69}$

A kar az előadók véleményes jelentése alapján Balogh István nyomtatásban benyújtott: »Velenczei diplomaták Magyarországról« c[ímü]. doktori értekezését cum laude fokozattal elfogadja és őt az egyetemes történelemböl mint fö-, magyar történelemböl és magyar müvelődéstörténelemből, mint melléktárgyakból szóbeli doktori szigorlatra bocsátja."70

Balogh sikeres doktori szigorlatára két nappal később, 1929. december 21-én szombaton került sor. Értekezésének két bírálója Fógel József ${ }^{71}$ és Erdélyi László $^{72}$ volt. Fógel - abban az időben a szegedi egyetem Közép- és Újkori Történeti Intézetének igazgatója - témavezetőként kedvelt kutatási területét adta a doktorandusz Balogh Istvánnak, hiszen korábban, még az 1910-es években jelentek meg könyvei a Jagelló-

69 Sajnos ezek nem maradtak fönn a Csongrád Megyei Levéltárban (a továbbiakban: CSML) őrzött egyetemi iratanyagban.

${ }^{70}$ CSML Szegedi Ferenc József Tudományegyetem Bölcsészettudományi Karának iratai. VIII. 2. 6. doboz 312/1929-30. 8 .

${ }^{71}$ Fógel József (1884-1941) a budapesti egyetem elvégzése után középiskolai tanárként dolgozott, majd a Magyar Tudományos Akadémia könyvtárának munkatársa lett. 1926-ban nevezték ki a szegedi egyetem nyilvános rendes tanárává, ahol halálig vezette annak Közép- és Újkori Történeti Intézetét. 1928-ban az akadémia levelező tagjává választották. Elsősorban a Jagelló-kor és a magyarországi humanizmus történetét kutatta. Főbb müvei közül: Velencei diplomaták Budán a XVI. század elején. Budapest, 1912.; II. Ulászló udvartartása. Budapest, 1913.; II. Lajos udvartartása. Budapest, 1917.; A Corvina-könyvtár állapota Mátyás király halála után a mohácsi vészig. Budapest, 1927.

72 Erdélyi László (1868-1947) 1892 és 1910 között főiskolai tanár, illetve levéltáros és könyvtáros volt Pannonhalmán. 1905-től a Magyar Tudományos Akadémia levelező tagja. 1911-ben nevezték ki professzorrá a kolozsvári Ferenc József Tudományegyetemre, amelynek Szegedre kerülésével maradt katedrájánál, s az 1936-37-es tanévben az egyetem rektora is volt. 1938. évi nyugdíjba vonulásától haláláig a Zalaapáti bencés rendház perjele. Történészként föleg középkori müvelődéstörténettel foglalkozott. Jelentősebb munkái közül: Szerémi György és emlékirata. Budapest, 1892.; A tihanyi apátság kritikus oklevelei. Budapest, 1906.; Magyarország társadalma XI. századi törvényeiben. Budapest, 1907.; Magyar müvelődéstörténet. I-II. köt. Kolozsvár, 1915-1918; A magyar lovagkor társadalma és müvelődése 1205-1526. Budapest, 1932.; A mohácsi vész nemzedéke. Budapest, 1941. 
kor velencei-magyar kapcsolatairól és magyar királyi udvar akkori életéröl. A disszertáció témáját valószínüleg - a korszak gyakorlatának megfelelően - a professzor adta a tanítványnak, vélhetően Balogh latin (és olasz) nyelvtudására alapozva.

A dolgozat másik bírálója, Erdélyi László professzor - aki a Kolozsvárról elüzött szegedi egyetemi tanárok csoportjához tartozott - szintén kutatta a kora újkori magyar egyház-, jog- és müvelődéstörténetet, s később Szerémi György (1490 k.-1548 k.) emlékirata (Epistola de perditione regni Hungarorum) alapján publikált is a korszakról. Erdélyi - lévén bencés szerzetes és fölszentelt katolikus pap - szimpátiával tekinthetett fiatal lelkésztársára, akiröl a kari tanács jegyzőkönyvében is fontosnak tartották megjegyezni, hogy „r[ómai]k[atolikus]. segédlelkész”.

Balogh István Velenczei diplomaták Magyarországról. 1500-1526 címü doktori értekezését a Szegedi Új Nemzedék - a helyi keresztény nemzeti szellemü napilap kiadójának, a Szegedi Új Nemzedék Lapvállalat Rt-nek a Korona (ma Hajnóczy) utca 1. szám alatti nyomdájában állították elö. A könyv A szegedi Magy[ar]. Kir[ályi]. Ferencz József-Tudományegyetem Közép- és Újkori Történeti Intézete kiadványainak második kötete volt.

A sorozat első darabja az íróként, költőként és Janus Pannonius-fordítóként ismert Berczeli Anzelm Károly (1904-1982) - eredeti nevén Vyhnalek Károly Giambattista Vico és a történelem címü, szintén 1929-ben kiadott doktori disszertációja volt. Néhány évvel később az állástalan diplomásként a szegedi városi könyvtárban segédkező és az egyetemen Fógel József mellett gyakornokoskodó Berczeli jelentkezett a Szeged tudományos és kulturális elitjét tömörítő Dugonics Társaságba. ${ }^{73}$ Pártfogója Hegyi István (1896-1951) író volt, aki írásbeli ajánlásában nem mulasztotta el megjegyezni barátja - akit mások mellett Móra Ferenc (1879-1934) is javasolt a társasági tagságra - érdemei sorolásakor, hogy doktorátussal bír: „Berceli Anselm [sic!] Károly 1904-ben született Szegeden. Filozófiai doktor.,"74

Balogh István disszertációja két részböl áll: a tizenhét oldalas bevezető tanulmányt csaknem nyolcvan oldalas jegyzetekkel ellátott bilingvis - olasz (középlatin) és magyar nyelvü - forrásközlés követi.

A bevezetés első egységében a szerző röviden áttekinti Velence koraújkori történetét, államformájának kialakulását, valamint bemutatja diplomáciájának

\footnotetext{
73 Miklós Péter: Berczeli A. Károly útkeresése. In: Uő: A szegedi bölcsészkar Radnóti Miklós diákéveiben. Tanulmányok Radnótiról, kortársairól és a szegedi egyetemről. Szeged, 2011. 123-130.

${ }^{74}$ CSML A Dugonics Társaság iratai. X. 58. 5. doboz 47/1932.
} 
jellemzőit. A tanulmány második részében a közreadott követjelentések forrásértékét és azoknak a tizenhatodik századi magyar történelem kutatásában való hasznosíthatóságát ismerteti, külön kitérve Marino Sanuto munkásságára, s Diariijának keletkezés- és recepciótörténetére. Ez utóbbi kapcsán említi Leopold von Ranke (1795-1886) megjegyzését, miszerint „a Diarii alapján kellene újra megírni az egész kornak a történelmét" ${ }^{75}$

Bár a velencei patríciuscsaládból származó történetíró, Marino Sanuto (14661536) több történelmi tárgyú munkát írt, legjelentősebb alkotásának kortörténeti naplója bizonyult. A Diariiban ugyanis 1498 januárja és 1533 szeptembere között följegyzett mindent, ami a velencei állam léte és históriája szempontjából fontos: megörökítette az összes tudomására jutott Velencével kapcsolatos bel- és külpolitikai információt, ismertette a Tanácsban - a Signoriában - lezajlott vitákat, lemásolta a velencei diplomaták rendszeresen küldött jelentéseit éppúgy, mint a követek mandátumuk lejártával adott részletes összefoglaló beszámolóit. ${ }^{76}$

Sanuto ötvennyolc kötetnyi, több tízezer oldalas kéziratát halála után közel kétszázötven esztendővel, 1784-ben fedezte föl Francesco Donà, Velence utolsó hivatalos történetírója, aki túl azon, hogy lemásoltatta, fölhívta az európai kutatók figyelmét páratlan forrásértékére. A tizenkilencedik században sorra tanulmányozták a historikusok, köztük a jogtudós és történész akadémikus Wenzel Gusztáv (1812-1891), aki a magyar történelemre vonatkozó részeket közzé is tette. ${ }^{77}$ Az ötvennyolc kötetes munkát Rinaldo Fulin, Federico Stefani, Guglielmo Berchet és Niccolò Barozzi rendezte sajtó alá és adta ki Velencében 1879 és 1907 között. Ezt az edíciót használta Balogh István is doktori értekezéséhez.

Balogh munkájában csatlakozik a történetírásunkban akkoriban elfogadott többek között Fógel József által is képviselt - állásponthoz, amely szerint a Jagelló-ház

\footnotetext{
75 Balogh István: Velenczei diplomaták Magyarországról. 1500-1526. Forrástanulmány. Szeged, 1929. (a továbbiakban: Balogh István, 1929) 13.

${ }^{76}$ Csukovits Enikő: Források, műfajok, lehetőségek: a középkori Magyarország-kép elemei. Korall, 10 (2009). 38. sz. 5-29. (10-11.)

77 Wenzel Gusztáv: Marino Sanuto világkrónikájának Magyarországot illető tudósításai. I. köt. 14961501. Magyar Történelmi Tár, 14. köt. Pest, 1869. I-XVI + 1-282.; II. köt. 1501-1515. Magyar Történelmi Tár, 24. köt. Budapest, 1877. 1-300.; III. köt. 1515-1526. Magyar Történelmi Tár, 25. köt. Budapest, 1878. 1-390.
} 
1490 és 1526 közötti regnálása „,idejére esik hazánk süllyedésének korszaka”. ${ }^{78}$ A középkori magyar állam 1526-os bukása kapcsán külön kiemeli II. Ulászló „,cseh király” felelősségét, aki szerinte „szellemileg sohasem volt kiválónak mondható”. ${ }^{79}$

Balogh István forrásközleménye bevezetésében számos idegen - latin, olasz, francia, német - nyelvü szakmunka mellett magyar történészek közleményeire is hivatkozik: többek között a már említett Wenzel Gusztáv, valamint a Római Magyar Történeti Intézetet megalapító nagyváradi kanonok és címzetes püspök Fraknói Vilmos (1843-1924) akadémikus és a szintén akadémiai tag csanádi egyházmegyés pap, Ortvay Tivadar (1843-1916) eredményeire. A legtöbbet azonban Fógel József könyveit és tanulmányait idézi.

A doktori értekezésben eredeti nyelven és magyar fordításban is közölt források a következők: Francesco de la Zuecha jelentése 1500-ból, Sebastian Zustignan jelentése 1503-ból, Zuan Badoer jelentése 1504-ből, Antonio Surian jelentése 1516-ból, Aluise Bon jelentése 1519-ből, Lorenzo Orio lovag jelentése 1523-ból, Francesco Massaro titkári jelentése 1523-ból és Vincenzo Guidoto jelentése 1525-ből. A nyolc követjelentés közül hétnek ez volt az első magyar nyelvü kiadása. (Sebastian Zustignan jelentését ugyanis Fógel József már korábban publikálta magyarul a Velencei diplomaták Budán a XVI. század elején [1912] címü könyvében.) ${ }^{80}$

\section{3. EIső politikai csatározásai Szegeden}

1929. október 17-én - a törvényhatósági jogú és rendezett tanácsú városok és a községek önkormányzatát szabályozó 1929. évi XXX. törvénycikk elfogadása után tartották Szegeden a törvényhatósági választásokat. A mandátumok óriási többségét beleértve a póttagságokat is - a kormánypárthoz hü Nagy-Szeged Párt nevü politikai csoport szerezte meg. Néhány képviselői hely azonban jutott a Rassay-féle liberálisok szegedi táborának és a szociáldemokratáknak is. A törvény rendelkezett arról, hogy a

\footnotetext{
${ }^{78}$ Balogh István, 1929. 17.

${ }^{79}$ Balogh István, 1929. 17.

${ }^{80}$ Balogh István, 1929. I-LXXXV.
} 
legtöbb egyenes adót fizető virilisták mellett a legnagyobb lélekszámmal bíró helyi vallásfelekezetek is képviselőt küldhetnek a törvényhatóságba - külön szavazás nélkül.

Szegeden hat katolikus lelkész lett a törvényhatósági bizottság tagja. Köztük a belvárosi plébános, Várhelyi József pápai prelátus. A népszerü és befolyásos Várhelyit azonban néhány hónappal később a testület örökös tagjává választották. A plébános aki immár személyében volt örökös tagja a törvényhatóságnak - a belvárosi plébánia képviseletében káplánjának, Balogh Istvánnak a behívását javasolta. Ezt azonban Somogyi Szilveszter polgármester 1930. január 30-án kelt levelében határozottan elutasította.

„Várhelyi József pápai prelátus, belvárosi plébános azt kéri, hogy a Szegedbelvárosi r[ómai]. kath[olikus]. egyházközség képviselőjéül, - miután ő a törvényhatósági bizottság örökös tagjává választatott meg, - dr. Balogh István belvárosi segédlelkész a törvényhatósági bizottságba rendes tagként behívassék. A kérelmet nem teljesítem." 81

A város első embere kifejtette, hogy Várhelyi személyében továbbra is képviseletet kap a belvárosi katolikus egyházközség, így az egyház jogai nem csorbulnak. „Az 1929:XXX. t. c. 4 §-ának 2-ik bekezdésében foglalt rendelkezés szerint a vallásfelekezetek a legnépesebb egyházközségeik élén álló lelkészek képviselik. Szegeden a törvényhez füzött meghatározás szerint hat r[ómai]. kath[olikus]. egyházközséget illeti, élükön álló lelkészeik személyében a törvényhatósági bizottságban képviselet. A Szeged-belvárosi egyházközség élén kétségtelenül Várhelyi József pápai prelátus, plébános áll, melléje koadjutor kirendelve nincs, őt tehát ebben a minőségben megillető törvényes jogát átvevő hatáskörrel helyettesíteni nem lehet. Azzal a ténnyel, hogy Várhelyi József prelátus mint egyházközsége élén álló lelkész örökös törvényhatósági bizottsági taggá választatott meg, nem nyílik lehetősége ahhoz, hogy helyébe az egyházközség képviselőjéül, annak élén nem álló - segédlelkész hivattassék be. Meg kell ezenkívül állapítani, hogy a belvárosi egyházközség, az élén álló lelkésznek: Várhelyi József prelátusnak örökös taggá történt megválasztásával tulajdonképpen nem is maradt képviselet nélkül, mert személyében - amitöl az egyházközség lelkészsége nem elválasztható -, az egyházközség érdekei is súlyos szavú képviseletet kapnak." ${ }^{, 82}$

\footnotetext{
${ }^{81}$ SZCSPL Püspöki Hivatal iratai. Egyházigazgatási iratok. (a továbbiakban: PHEI) 420/1930.

${ }^{82}$ SZCSPL PHEI 420/1930.
} 
Somogyi Szilveszter másik indoka az volt Balogh behívása ellen, hogy a törvény alapján lehetséges, hogy egy egyházközségnek ne legyen képviselője. Ilyen eset például a plébános akadályoztatása, tartós betegsége, vagy a plébánia be nem töltöttsége. Ilyenkor a segédlelkész, vagy helyettes plébános nem lehet közgyülési tag, hiszen az csak a - Szeged város kegyúri bizottsága által - törvényesen megválasztott és beiktatott lelkészt illeti meg. ${ }^{83}$ A polgármester hangsúlyozta azonban, hogy a belvárosi egyházközség érdekeit Várhelyi József továbbra is képviselni tudja, s így az nem marad képviselet nélkül. Végkövetkeztetése: „Ezen indokokra fektetett meghatározásom szerint dr. Balogh István segédlelkész behívását, mint törvényes alappal nem bírót, meg kell tagadnom." 84

Balogh végül 1933-ban - szeged-alsóközponti plébánossá való kinevezésével lett tagja a törvényhatósági bizottságnak. S bár nagyon szeretett volna tag lenni, a törvényhatóságban nem volt túl aktív, noha az ülések nagy részén jelen volt, nem szólalt föl (ez egyébként későbbi, nem túl jelentős parlamenti tevékenységére is igaz).

1936. február 22-én „kimondotta a közgyülés, hogy az 53000/1929. sz. VKM rendelet $6 \S$-ában foglaltak alapján névszerinti titkos szavazással 1936. év január hó 1-töl 1941. év december hó 31-ig szóló megbízatással: 1.) az alsóközponti állami elemi iskolai gondnokságba: dr. Balogh István plébános, Wagner Gyula th. bizottsági tagot, Dobó Imre gazdálkodó th. biz. tagot Királyhalom 248., Kószó István gazdálkodó Királyhalom 318., Pálfy Ferenc gazdálkodó Mórahalom 57., és Nyilasy Pál kerületvezető, Mórahalom 436. sz. alatti lakosokat [...] megválasztotta." ${ }^{85}$

A Balogh István szerkesztésében megjelenő Szegedi Hírlap címü napilap 1930. július 18-i számában beszámolt az elhunyt Almássy Endre színigazgató özvegye javára rendezett jótékonysági estről. A Szegedi Nemzeti Színházban tartott rendezvényen több színdarab került elöadásra. A Szegedi Hírlap a Csak röviden uraim, csak röviden... című egyfelvonásos darabot bírálta. A közönség - írta az újság - „...a helyi kabarészerzőtől származó Csak röviden uraim, csak röviden... című tragikomédia alatt

\footnotetext{
83 Kisházi-Kovács László: A városi kegyuraság Szegeden. 1917-1948. Budapest-Szeged, 2001. (a továbbiakban: Kisházi-Kovács László, 2001) 13-29.

${ }^{84}$ SZCSPL PHEI 420/1930.

${ }^{85}$ CSML Szeged város törvényhatósági bizottságának iratai. Közgyülési jegyzőkönyvek. IV. B. 1402. a. 1936. 64. kötet 1936. február 22. 14. pont
} 
már elvesztette a türelmét. És legfőbb ideje volt, hogy a negyedórásnak beígért, de a valóságban igen hosszúra nyúló és így a címét is meghazudtoló komédia véget ért."86

A rövid komédia szerzője Dobay Gyula ügyvéd volt. A lap tudósítója valószínüleg Balogh István - a müvet nemcsak unalmasnak, vontatottnak és nehéz fogalmazásúnak nevezte, de íróját plágiummal is vádolta: „Egyébként ezt a bírósági heccet nem most halljuk először, mert a »Magyarság« egyik három év elötti számában sokkal jobb, eredetibb beállításban és döcögés nélküli leírásban már olvastuk, hozzátéve még, hogy abban a novellában is a »szegedi embör« állt a bíróság előtt." ${ }^{87}$

A sértődött Dobay Gyula elégtételt követelt, s személyesen fejezte ki fölháborodását Baloghnak. Ezért a lap 1930. augusztus 4-i számában nyilatkozatot közölt, amelyben - egyebek mellett - a következőket olvashatjuk: „Készséggel kijelentjük, hogy a megjelent kritika ismert formájában szándékunk ellenére tétetett közzé. Ezen nyilatkozattal kívánunk elégtétel szolgáltatni a szerzőnek, akit sem irodalmi müködésében, sem személyében sérteni nem akartunk." ${ }^{88}$

Ez a szöveg azonban sem a bocsánatkérést, sem a plágium vádja alóli mentesítést nem tartalmazta. Így Dobay 1930. augusztus 6-án levelet írt a szerkesztőnek: „Ez nem csak elégtételt nem ad nekem, hanem még azon kitételével, hogy a megjelent kritika ismert formájában tétetett szándék ellenére közzé, még megerősíti a kritikának a tartalmát, vagyis azt a valótlan állítást, amely a plágium bélyegét igyekszik rám sütni, holott nem a forma a fö, hanem a szavak értelme." ${ }^{\text {,89 }}$

A Dobay Gyulával való vitából Balogh nem kerülhetett ki győztesen. Dobay ugyanis köztiszteletben álló, befolyásos szegedi polgár volt, közismerten kormánybarát és katolikus. Az „erőviszonyok” tisztázása miatt érdemes röviden vázolni életútját. Dobay Gyula (1870-1937) Pillich Kálmán (1840 -1922) ügyvéd, városi szabadelvü politikus házasságon kívül született fia volt, aki ezért anyja után kapta családi nevét. A szegedi piarista gimnázium elvégzése után Budapesten tanult jogot. 1896-ban tett ügyvédi vizsgát, és élete végéig Szegeden praktizált. Az árvíz utáni újjáépítésben nagy szerepet játszó Pillich Kálmán mellett volt jelölt, aki később társává fogadta, majd ráhagyta irodáját.

\footnotetext{
${ }^{86}$ Szegedi Hírlap, 1930. július 28. 5.

${ }^{87}$ Szegedi Hírlap, 1930. július 28. 5.

${ }^{88}$ Szegedi Hírlap, 1930. augusztus 4. 5.

${ }^{89}$ SZCSPL PHEI 3494/1930.
} 
$\mathrm{Az}$ első világháborúban katonaként számos kitüntetést szerzett, századosi ranggal szerelt le. 1919-ben alapító tagja az Antibolsevista Comitének, a Nemzeti Hadsereg szervező elnöke, helyettes kormánybiztos volt. 1920 után a városi törvényhatósági bizottság tagja, majd Szeged tiszteletbeli föügyésze lett. Egyik tulajdonosa és egy ideig főszerkesztője a konzervatív Szegedi Új Nemzedéknek. A felsővárosi katolikus egyházközség világi elnöke, a minorita harmadrend tagja, a Szegedi Katolikus Kör egyik alapítója és elnöke. ${ }^{90}$ Konzervatív, keresztény ember volt, és - mint az alább idézett sorokból is kitünik - a liberalizmus és a szocializmus esküdt ellensége.

Dobay 1930. augusztus 6-án Balogh elöljárójának, Várhelyi József belvárosi plébánosnak is írt. A „Drága Jó Józsi Bácsi!” megszólítással kezdődő levélben az ügyvéd kifejtette, hogy minden kritikát elfogad - ha az jogos és megalapozott. Utalt arra is, hogy egy paptól az alázatosság inkább elvárható, mint a támadó és kritizáló hangnem. „Minden kritika szabadon nyilváníthatja véleményét, de csak a jogosság határán belül, ami azt jelenti, hogy csak igazat szabad neki írni, még célzatosan is. Az a kritika azonban, amelyet az alázatosság papi köntösében járó személy követett el ellenem, nem jogos kritika, hanem minden ok nélkül az én személyem lekicsinylése és írói becsületem pellengérre állításra törekvő írásmü volt."91

Balogh István cikkét gunyoros hangvételünek, rosszindulatúnak minősítette, amelynek célja az ő lejáratása és a közönség félrevezetése volt. Dobay Gyula közölte a plébánossal, hogy ilyen vagy hasonló darab a Magyarság címü lapban soha nem jelent meg. Az ő müvének egy korábbi változata azonban - Nikoláj címmel - valóban napvilágot látott a Szegedi Új Nemzedék 1920-as évfolyamában, amelyet természetesen ő írt. „A plágium vádja tehát annyira szemenszedett valótlanság, hogy ezzel még az ellenséges világnézetű szélső kommunisták sem mernének megvádolni." - írta. ${ }^{92}$

Különösen sértőnek találta, hogy a kritika szerzője még csak meg sem nevezte, hanem egyszerűen „helyi szerzőként” utalt rá. „Midőn engem, a keresztényellenes liberális lapok kifejezésmódjával, helyi szerzőnek nevez, ez a lekicsinylésnek oly impertinens kifejezése, amelyhez már szó sem férhet, különösen akkor, midőn ezt az egyik kath[olikus]. egyházközség világi elnökének személyére vonatkoztatja."93

\footnotetext{
${ }^{90}$ Habermann Gusztáv: Személy adattár a szegedi polgárcsaládok történetéhez. Szeged, 1992. 57-58.

${ }^{91}$ SZCSPL PHEI 3494/1930.

${ }^{92}$ SZCSPL PHEI 3494/1930.

${ }^{93}$ SZCSPL PHEI 3494/1930.
} 
Kijelentette, hogy az elégtétel vagy maga szerzi meg, vagy bírósági úton szerez érvényt igazának. (Azt viszont nem részletezte, hogy ő hogyan tudott volna elégtételt venni.) „Én az elégtételt csak úgy kaphatom meg, ha vagy magam szerzem meg, vagy a bírósághoz fordulok, vagy pedig mindkét utat igénybe veszem azon személy ellen, aki a legkisebb lelkiismeret-furdalás nélkül megpróbált lehetetlenné tenni engem, aki 40 év óta állok a kereszténység önzetlen szolgálatában."94

A levélben egy érdekes epizódot is olvashatunk. Dobay hivatkozott rá, hogy néhány héttel korábban hasonló ügyben Várhelyi kérte az ö segítségét. A lelkész ugyanis úgy gondolta, hogy a Szegedi Új Nemzedék egyik szerkesztői üzenete rá nézve sértő megjegyzéseket tartalmaz. Ezért kérte az ügyvédtől, aki - mint már említettük - a lap egyik tulajdonosa volt, hogy bocsássa el az újságírót. Ezt Dobay nem tette meg, mondván, hogy a publicista okiratokkal bizonyította, hogy nem Várhelyi Józsefre utalt. „Én jogosnak tartottam a kérésedet, mert a kereszténység szolgálatában álló előkelő egyént még csak célzattal sem szabad megbántani...” - írta Dobay Gyula, ezzel párhuzamot vonva a két eset között. ${ }^{95}$

$\mathrm{Az}$ utolsó sorokban a sértett ügyvéd az elégtétel legegyszerübb és legjobb módjaként Balogh bocsánatkérését nevezte meg: „Természetes dolog, hogy én közvetlenül nem fordulhatok hozzá, de ha ő már meggyőződött volna a kritikájának a helytelenségéről, tapintatlanságáról és a plágium vád valótlanságáról és annak következményeit levonni hajlandó, úgy én nem zárom el az útját és arra Általad módot nyújtok neki, és néhány napig várok az elégtétel e módjának a felajánlására."96

Balogh István végül bocsánatot kért Dobaytól. Közéleti pályájának és társadalmi megítélésének azonban ez az eset nem használt. Hírlapírói tevékenysége, cinikus és kritikus hangvétele miatt a város vezetői közül sokan nehezteltek rá. Később, SzegedAlsóközpont papjaként is nemegyszer kivívta a polgármester és a föispán haragját.

\footnotetext{
${ }^{94}$ SZCSPL PHEI 3494/1930.

${ }^{95}$ SZCSPL PHEI 3494/1930.

${ }^{96}$ SZCSPL PHEI 3494/1930.
} 


\section{4. A Szeged-alsóközponti plébánián ${ }^{97}$}

A tizenkilencedik század végén Szeged külterületein nagy számú római katolikus lakosság élt. Ezért Szeged szabad királyi város törvényhatósága 220/1891. szám alatt határozatot hozott a külterületeken - alsó- és fölsőtanyai központokon katolikus lelkészségek létrehozásáról; ehhez a csanádi püspök 1509/1892. számú levelében hozzájárult. A szegedi törvényhatósági bizottság 1892 novembere és 1893 júniusa között többször napirendre tüzte a tanyai lelkészségek létrehozásával kapcsolatos feladatok és nehézségek megvitatását.

Szeged város és a csanádi egyházmegye képviselői 1894-re kidolgozták a külterületi katolikus plébániák területi beosztását és a lelkészek javadalmazási viszonyait. Dessewffy Sándor csanádi püspök 1894. szeptember 18-án Temesvárott kiadott, 2463/1894. számú rendeletével átszervezte a szegedi katolikus plébániákat. Létrehozta a szeged-alsóközponti és szeged-fölsőközponti lelkészségeket; szabályozta területi beosztásukat, meghatározta a lelkészek jövedelmének forrásait. A stóladíjak fölosztását a következőképpen szabályozta a rendelet: egy rész a plébánost, egy rész a kápolna/templom pénztárát, egy rész pedig a harangozót/sekrestyést illeti. A sekrestyés javadalmát hetenként kell kiadni, a kántort Szeged város - az egyházmegyei hatósággal egyeztetve - jelöli ki és díjazza. ${ }^{98}$

A szeged-alsóközponti lelkészség első adminisztrátora Hoschek János ferences atya. Az 1910-es évektől a ferences rend nehezen tudta ellátni az alsóközponti hívek ellátását, ezért Szeged város világi, egyházmegyés papokra bízta az alsóközponti lelkészség vezetését. Első plébánosa Barmos György- egykori ferences házfőnök - lett, 1914. szeptember 1 -jétől. ${ }^{99}$

A két új lelkészség (Alsóközpont és Fölsőközpont) alapításának legfőbb oka a katolikus tanyai lakosság nagy lélekszáma volt. A nagy távolságok miatt csak

\footnotetext{
${ }^{97}$ Az ebben az egységben tárgyaltakról lásd bővebben: Miklós Péter: Balogh páter, a szeged-alsóközponti plébános (1933-1946). Magyar Egyháztörténeti Vázlatok, 16 (2004). 3-4. sz. 125-154.

${ }^{98}$ Miklós Péter: A szegedi katolikus plébániák 1984. évi átszervezése. In: Uő: Város, egyház, társadalom. Tanulmányok a szegedi katolicizmus történetéröl. Szeged, 2004. 10-17.

${ }^{99}$ Vö. Giczi Zsolt: Szeged katolicizmusa az 1930-as években. Szeged, 1990-91. 12-13. sz. 20-27.
} 
nehézségek árán lehetett ellátni a tanyákat, ezért szükségessé vált közelebbi egyházi központok létrehozása. Ezt mutatják a plébániák 1898-as adatai: Szeged-Alsóközpont: 919 keresztelés, 182 házasság, 447 halálozás; Szeged-Felsőközpont: 498 keresztelés, 84 házasság, 239 halálozás. ${ }^{100}$

A szeged-alsóközponti plébánián (a mai Mórahalom) 1894. augusztus 12. óta folyik anyakönyvezés. Első kápolnáját a szegedi árvíz emlékére építették Szent Mihály arkangyalnak szentelve. Ezt az egyházi épületet 1892-ben áldották meg. A területre 1854 óta szegedi - főleg alsóvárosi eredetű - családok telepedtek. A lelkészség vezetését kezdetben a ferences rend látta el, tőlük 1914-ben vette át az egyházmegyei papság. A mai templom 1903-ban készült el, Szent László király tiszteletére. ${ }^{101}$

A szegedi római katolikus plébániák 1894-es átszervezése lezárt egy területi vitát a belvárosi és az alsóvárosi lelkészségek között, megoldotta a város környéki tanyai lakosság lelki ellátásának problémáját, valamint tovább erősítette SzegedAlsóközpont és Szeged-Felsőközpont közigazgatási centrum jellegét. Ezzel alapot biztosított Mórahalom és Balástya községek létrejöttéhez.

\section{A szeged-alsóközponti plébánia lakosságának felekezeti megoszlása az 1930-as-1940-es évek fordulóján ${ }^{102}$}

\begin{tabular}{|l|c|}
\hline Római katolikus & 8012 \\
\hline Görög katolikus & 12 \\
\hline Evangélikus & 72 \\
\hline Református & 264 \\
\hline Ortodox & 17 \\
\hline Zsidó & 72 \\
\hline Egyéb & 7 \\
\hline Összesen & 8446 \\
\hline
\end{tabular}

\footnotetext{
100 Schematismus venerabilis cleri dioecesis Csanádiensis pro anno Domini (a továbbiakban: SCS) 1898. 140. és SCS 1900. 196.

${ }^{101}$ Vö. G. Tóth Ilona: Szeged-Alsótanyától Mórahalomig. In: Mórahalom. A település földje és népe. Szerk. Juhász Antal. Mórahalom, 1992. 103-135.

${ }^{102}$ SCS 1936. 30-31., SCS 1942. 41-43. és SCS 1947. 16-17. alapján. 1936-ban, 1942-ben és 1947-ben ugyanazok az adatok szerepelnek az egyházmegyei sematizmusokban.
} 
Szeged-Alsóközpont lakosságának, Balogh István plébánossága alatti (19331946) felekezeti megoszlását a fönti táblázat mutatja. Sajnos a csanádi egyházmegye 1936-os, 1942-es és 1947-es névtárában - sematizmusában - ugyanazokat az adatokat találjuk. A táblázat csak Alsóközpont adatait tartalmazza. Királyhalom - a filia (leányegyház) - katolikus lakossága kb. 2400 fös volt a harmincas-negyvenes évek fordulóján. $^{103}$

Glattfelder püspök Balogh Istvánt 1933. március 1-jei hatállyal SzegedAlsóközpont plébánosává nevezte ki. Balogh újságírói, lapszerkesztői tevékenységét új állomáshelyén is folytatta. 1933 májusától - a Szegedi Hirlap helyett, annak megszüntetésével egyidejüleg - megindította a Tanyai Újságot. A lap a szegedi tanyai lakosságot informálta a város és a közélet aktuális eseményeiröl. A keresztény elkötelezettségü, nemzeti irányzatot képviselö újság népszerü volt a nagyszámú tanyai katolikus lakosság körében.

A Tanyai Újság fönntartásához azonban az egyházmegye támogatására is szükség volt. Ezért Balogh páter 1933. július 31-én így írt a püspöknek: „Mély tisztelettel azon alázatos kérelemmel járulok a Főtisztelendő Püspöki Hivatalhoz, hogy a Tanyai Újság részére méltóztatnék kiutalni azt a 20.- pengőnyi havi segélyt, melyet a Szegedi Hírlap is élvezett. A Tanyai Újság a Szegedi Hírlapnak utódja, mely az eddiginél is fontosabb pozícióban iparkodik szolgálni a katolikus gondolatot és a hívek lelki és anyagi érdekeit. A kezdet nehézségeivel küzdve pedig nemcsak rászolgál, hanem rá is szorul a kegyes támogatásra." 104

Glattfelder csaknem egy hónap múlva válaszolt. 1933. augusztus 25-én írott levelében jóindulatáról és támogatásáról biztosította a lelkész kezdeményezését, de hangsúlyozta, hogy csak akkor ad anyagi támogatást, ha a lap ,,az egyház érdekeinek” szem előtt tartásával és képviseletével jelenik meg. „A Szegedi Hírlap által élvezett 20 P-s segélyt a Tanyai Újság számára folytatólagosan csak akkor fogom engedélyezni, ha meggyőződtem róla, hogy az egyház érdekeinek minden tekintetben kielégítő szolgálatot tesz. Addig is a kiadó buzdítására és anyagi gondjainak enyhítésére, de jóakaratom jeléül is hivatalom útján $50 \mathrm{P}$ segélyösszeget küldöttem."105

Két évvel később, 1935 őszén Balogh István a lap kiadói jogát átadta Back Károlynak, aki vállalta, hogy a Tanyai Újságot „,keresztény nemzeti szellemben” fogja

\footnotetext{
${ }^{103}$ SCS 1936. 30-31., SCS 1942. 41-43. és SCS 1947. 16-17.

${ }^{104}$ SZCSPL PHEI 2166/1933.

${ }^{105}$ SZCSPL PHEI 2166/1933.
} 
megjelentetni. Ruszoly József írásában olvasható, hogy Back Károly szerkesztő neve Bak és Bach alakban is elöfordul. Az 1930-ban alakult Független Kisgazdapártot ő szervezte Szegeden, 1937-től egyre nagyobb intenzitással. ${ }^{106}$ A párt az 1939. évi országgyülési választásokon a városban a szavazatok nyolc százalékát szerzete meg, de ez mandátum szerzéséhez kevés volt. A „begavári” nemesi előnevet viselő Back Károly tisztviselő bizonyosan rokona volt Back Bernát vállalkozónak, malomtulajdonosnak, aki Szegedet képviselte a parlament fölsőházában.

Az újság eladásáról Balogh 1935. október 3-án tudósította az egyházmegyei hatóságot. „Legyen szabad mély tisztelettel jelentenem, hogy a Tanyai Újság kiadói jogát begavári Back Károly szegedi lakosra ruháztam át, illetőleg olyan értelmü kérvényt intéztem a miniszterelnökség sajtóosztályához, hogy ezen átíráshoz a hozzájárulást megadja. Begavári Back Károly megállapodásunk értelmében kötelezettséget vállalt arra nézve, hogy a Tanyai Újság továbbra is keresztény nemzeti szellemben fog megjelenni és különösen a tanyai katolikus lakosság vallási érdekeit a leghatározottabban fogja szolgálni." "107

Balogh az 1930-as évek második felében a püspökkel való levelezésében - és több más fórumon is - gyakran hivatkozott a korszak politikai rendszerének hivatalos ideológiája, a keresztény nemzeti eszme melletti elkötelezettségére. Nem csoda, hogy 1937-ben jelezte belépési szándékát a kormánypárt - a Nemzeti Egység Pártja - szegedi szervezetébe, ahová azonban végül - közéleti és politikai konfliktusai miatt - nem vették föl. ${ }^{108}$

1936-ban a Szeged környéki tanyákon megélénkültek a „szektárius mozgalmak”. A Jehova Tanúi kisegyház tagjai toboroztak maguknak követőket - a katolikus hívek köréből. ${ }^{109}$ Balogh 1936 novemberében tudósította a püspököt egy esetröl, amely egy tanyai iskolában történt. „Folyó hó 26-án történt a plébániám területéhez tartozó Madarász-tói iskolában, - ahol, mint sajnos több más tanyai iskolában is, két női tanerő teljesít szolgálatot - statisztikai adatok összegyüjtése címén megjelent Juhász Ferenc, a városi munkaközvetítő hivatal által alkalmazott szellemi ínségmunkás az ottani esküdt

\footnotetext{
${ }^{106}$ Ruszoly József, 1999. 138-140.

${ }^{107}$ SZCSPL PHEI 2774/1935.

108 Shvoy Kálmán titkos naplója és emlékiratai. 1918-1945. S. a. r., bev., jegyz.: Perneki Mihály. Budapest, 1983.135.

109 A szektakérdés harmincas évekbeli egyházi és politikai megítéléséről bővebben: Fazekas Csaba: Kisegyházak és szektakérdés a Horthy-korszakban. Budapest, 1996. 84-166.
} 
kíséretében. A hivatalos dolgokat elvégezve a növendékekhez kommunista tartalmú beszédet intézett, többek között: amíg a papokat és az urakat el nem kergetjük, mindig rossz sora lesz a népnek. Felhívta a gyermekeket arra, hogy csatlakozzanak ők is, szüleik is Jehova-tanuihoz."110

Balogh plébános javaslatot nyújtott be a püspöknek. Ennek négy pontjában rámutatott a „speciális tanyai körülményekre”, és a fölmerülő problémák megoldási lehetőségeire. Elöször a (legtöbbször fiatal) tanyai tanítónők helyzetére hívta föl a figyelmet, akik ugyan jól nevelik a gyermekeket, de közéleti, társadalmi szerepet helyzetükből adódóan - nem vállalhatnak. A férfi tanítóknak nagyobb tekintélye volt a tanyai emberek szemében. „Az illetékes hatóságoknál már ismételten kértem élőszóval és írásban, sőt kezdeményezésemre a sajtó is foglalkozott azzal a kérdéssel, hogy a tanyára lehetőleg ne tanítónőket, hanem tanítókat, azok közül is a kiválóbbakat küldjék. Az a helyzet, hogy több iskolában csak tanítónök müködnek, nem ritka esetben éppen városi származású fiatal lányok. Az ilyenek a gyermekekkel szemben a tanteremben kifogástalanul teljesítik kötelességüket, az iskolán kívüli népmüvelésre azonban, különösen pedig arra, hogy az iskola környékének lakosságára hatással legyenek, majdnem egészen alkalmatlanok. A tanyai plébános nagyon rászorul arra, hogy vele tanítói teljes mértékben együtt müködjenek, neki szinte káplánokként segítségükre legyenek.",111

Balogh fontosnak tartotta önálló hitoktató alkalmazását a nagy kiterjedésű szegedi tanyavilágban. A hitoktató - aki fiatal fölszentelt pap lenne - illetményét a négy tanyai plébánia együtt állná, így egyik egyházközségre sem hárulna anyagi erejét meghaladó teher. „A tanyai hitoktatás nagy általánosságban tanítókra, illetőleg tanítónőkre van bízva. Bizonyos, hogy iparkodnak a hitoktatást lelkiismeretesen elvégezni. Az iskolai látogatások alkalmával, valamint a vizsgák eredményeiből is meggyőződtem arról, hogy az anyag betü szerint való tanítása miatt kifogást tenni nem lehet. Mégis összehasonlíthatatlanul más volna az eredmény, ha azt lelkész végezné. Talán lehetne arra a megoldásra módot találni, hogy egy önálló tanyai hitoktatói állás szerveztessék."

A lelkész szerint a tanyai rendőrség létszáma alacsony, ezért nem tudnak elég hatékonyan müködni. Ráadásul - írja Balogh István - a hatóság túlságosan elnéző a

\footnotetext{
${ }^{110}$ SZCSPL PHEI 3474/1936.

111 SZCSPL PHEI 3474/1936.

112 SZCSPL PHEI 3474/1936.
} 
térítőkkel szemben. Legtöbbször csak tiltott gyülés vagy engedély nélküli könyvterjesztés ellenük a vád, amit néhány pengős pénzbírsággal megúsznak. „Alsótanyán 50 ezer hold területen jelenleg 6 rendör teljesít szolgálatot. Közvetlen tapasztalatunk szerint ez a csekély létszámú rendőrség szinte emberfeletti munkát végez. Ennek dacára tudnia kellene az illetékes tényezőknek, hogy ez a létszám az őket terhelő feladatok elvégzésére már a komolytalanság határait közelíti meg."113 A levél írójának álláspontja a szekták tanításainak képviselőivel kapcsolatban az, hogy ha „,..a vallás és a társadalmi rend elleni izgatás címén vonnák öket felelösségre, amint erre lehetőség kínálkozik, bizonyára nem mernének ezek az ügynökök olyan fesztelenül mozogni."114

Balogh István szerint fontos volna, ha a város által kisbérlőknek kiadott földek bérlői megbízható, a nemzeti és keresztény eszme mellett elkötelezett emberek lennének. „...kívánatos volna, hogy bérletet olyanok ne kaphassanak, akik ezen vallás és haza elleni agitációnak agitátorai, tehát nem áldozatai, mert ez utóbbiak rosszhiszemüsége bizonyítva nincsen és okkal-móddal megmenthetők, de inkább jó szóval és szeretettel, mint erőszakkal."115

A levél utolsó bekezdése Balogh egyik érdekes tervére utal. A kisteleki esperesi kerület gyülésén javasolta, hogy a tanyai plébániák közösen adjanak ki naptárat, amelyet a hívek között ingyen osztanának szét. Az könyvben megjelenő hitbuzgalmi és ismeretterjesztő írások ellensúlyai lehetnének a Jehova Tanúi által terjesztett írásoknak. A lelkészek azonban - pénzhiányra hivatkozva - elutasították az elképzelést. Balogh István - valószínüleg Prohászka Ottókár és Bangha Béla közismert munkássága nyomán - helyesen ismerte föl, hogy a sajtó útján könnyen és eredményesen lehet hatni az emberekre. Különösen a tanyai lakosokra, akiknek többségéhez „más sajtótermék nem jár”. „Ez alakalommal kell sajnálkozásomnak kifejezést adnom amiatt, hogy az a javaslatom, amelyet a múlt őszi Coronán ${ }^{116}$ terjesztettem elő egy közös tanyai naptár elöállítására nézve, mely a hívek között ingyen lett volna szétosztandó, a tanyai plébánosok között visszhangra nem talált."

\footnotetext{
${ }^{113}$ SZCSPL PHEI 3474/1936.

${ }^{114}$ SZCSPL PHEI 3474/1936.

115 SZCSPL PHEI 3474/1936.

${ }^{116}$ Corona $=$ az esperesi kerület papjainak gyülése

${ }^{117}$ SZCSPL PHEI 3474/1936.
} 
Glattfelder válaszlevelében kifejtette, hogy szerinte Jehova Tanúinak müködése nem buzgó hívek tevékenysége, hanem kommunista agitátorok vallásos köntösbe bújtatott izgatása az államhatalom és a katolikus egyház ellen. „A tanyai szektárius mozgalmak erőszakos és perfid próbálkozása tárgyában már többször nyilatkoztam illetékesek előtt s legutóbb magának a főispán úrnak és a polgármester úrnak a figyelmét is felhívtam a szektákra, megmagyarázván elöttük, hogy ezekben az esetekben nem vallásos igények kielégítéséről, hanem vallásos köpenybe burkolódzó, bolsevista propagandáról van szó s úgy láttam, hogy kijelentésemet mind a ketten megértették. A polgármester úr különben azt a fölvilágosítást adta, hogy amennyiben ismeretlen forrásból pénzelt kommunista agitátorok eljárását kellene megakadályozni, a jövőben a fölemelt létszámmal dolgozó rendőrhatóság éber figyelemmel fog őrködni." "118

A főpap elismerte, hogy a szekták terjedése ellen nemcsak a rendőrségnek kell föllépnie. Jól szervezett plébánián, erös egyházközségben, ahol a lakosság nagy részével a lelkipásztorok személyes kapcsolatban vannak, nem tudnak sok hívőt elhódítani a kisegyházak. A katolikus egyház és a keresztény nemzeti kormány között közismerten jó volt az együttmüködés, így az egyház erösödése az államnak is érdeke volt. A katolikus törekvéseket - mint láthatjuk, helyi szinten is - az állami közigazgatás mindig támogatta. Glattfelder önálló hitoktató tanyai kiküldését szorgalmazta, erre azonban az egyház nem talált volna fedezetet, a vallás- és közoktatásügyi minisztérium támogatása híján. „Önálló tanyai hitoktató kirendeléséről azonban egyelőre sajnos nem lehet szó, miután ezeknek a száma kontingentálva van és a minisztérium részéröl állandóan hangoztatják, hogy új hitoktatói állásokra nincs fedezet."

A püspök úgy gondolta, hogy Szeged-Alsóközponton - ahol egy plébános és egy segédlelkész tevékenykedett - újabb kápláni állást kell szervezni. A papi létszám emelésével a nagy kiterjedésű tanyavilágban javulna a hívek lelki ellátása. A lelkészek a plébánia legtávolabbi pontjaira is el tudnának jutni: hitoktatást, misét, szertartásokat tartani. „...csakis a II. kápláni állás szervezését lehet majd megkísérelni abban az esetben, ha a kápláni fizetés legalább félösszegben - ami 350-400 P[engő]-t jelent -

\footnotetext{
${ }^{118}$ SZCSPL PHEI 3474/1936.

${ }^{119}$ SZCSPL PHEI 3474/1936.
} 
helyi forrásból biztosíthatónak látszik, s ezenfelül a kirendelendő új munkaerő lakást és teljes ellátást is kaphat." 120

Balogh István 1938. december 18-án - saját lelkészi hivatalának iktatása szerinti - 157/1938. szám alatt jelentette a püspöki hivatalnak, hogy az alsóközponti templomba betörtek. A perselyeket kifosztották, s onnan a - mindennapos használatra ott tartott liturgikus kelyheket, edényeket elvitték. Az értékesebb monstranciát és kelyheket a plébánián őrizték, ezért azok megmaradtak, de a kár meghaladta az ezer pengőt. „Mély szomorúsággal teszek jelentést arról, hogy a szegedalsóközponti plébániatemplomba a múlt éjjel betörtek, a szentedényeket elrabolták, a perselyeket kifosztották. Ruhanemüben a templomot károsodás nem érte. Hiányzik a használatban volt áldoztató kehely, melyből a szent ostyát a Tabernákulum ${ }^{121}$ elé, az oltárra szórták. Hiányzik a betegellátásnál használt 2 ezüst szelence, végül a hordozható oltár felszereléséből a miséző kehely, az áldoztató kehely és ugyanonnan 3 bronz olajszelence. A kár eléri az 1.000 P-t, mely - hála az Egyházmegyei Hatóság rendelkezésének - biztosítás révén teljesen megtérül. A monstranciát ${ }^{122}$, a legértékesebb kelyheket, valamint a templomi fehérnemüt állandóan a lakásomon őrzöm úgy, hogy az újonnan beszerzendő szentedények megérkezéséig is a templom el van látva."123

A kár nagyságát érzékelteti, hogy a plébánia 1938. augusztus 26-án kilencszázhatvan pengőért két négyszáz négyszögöles telket tudott vásárolni Szeged városától. Pálffy József polgármester szeptember 29-én kérte a szerződéshez Glattfelder püspök jóváhagyását, amit október 23-án meg is kapott. A szerződés másolatát Balogh plébános 1939. január 10-én küldte meg az egyházmegyei hatóság illetékeseinek. ${ }^{124}$

Balogh páter 1939. október 9-én levelet írt Pálffy József polgármesternek, amelyben kétszáz darab gyüjtőív kibocsátására kért engedélyt. A tanyai lakosság egy csoportja ugyanis templom építését határozta el, akik az anyagiak előteremtésére gyüjtést akartak szervezni, sőt már templomépítő bizottságot is szerveztek. „Van szerencsém mély tisztelettel bejelenteni, hogy a Szeged-alsóközponti plébánia híveinek azon része, akik a Feketeszélen, Nagyszéksós és Mórahalom kapitányság környékén laknak, szeretnének a bojárhalmi iskola tájékán, körülbelül ott, ahol a szikelt út

\footnotetext{
${ }^{120}$ SZCSPL PHEI 3474/1936.

${ }^{121}$ Tabernákulum = az oltárban elhelyezett kis szekrény, amelyben az Oltáriszentséget őrzik.

${ }^{122}$ Monstrancia $=$ szentségtartó, szentségmutató.

${ }^{123}$ SZCSPL PHEI 3521/1938.

${ }^{124}$ SZCSPL PHEI 3010/1938.
} 
keresztezi a bajai müutat, templomot építeni. Ezen célból megalakítottuk a templomépítő bizottságot, melynek világi elnöke Takács Sándor és Császár Rudolf gazdaköri elnökök, ügyvezető alelnöke pedig Ördög István, ugyancsak gazdaköri elnök." 125 - írta Balogh.

A kegyúr város első embere „a bojárhalmi kápolna felépítése érdekében szükségesnek mondott gyüjtés engedélyezése iránti kérelmét” - jóváhagyást kérve elküldte a püspöknek. A föpap nem is tudott a kezdeményezésről, ezért számonkérő hangnemü levelet írt Baloghnak, aki a püspöki hivatalt meg akarta kerülni, vagy legalábbis kész tények elé állítani. „Miután nincsen tudomásom róla, micsoda kápolna építéséről van szó, felhívom Tisztelendőségedet, hogy az építendő kápolna tervét és hozzávetőleges költségvetését a kiszemelt építési hely vázrajzával hozzám jóváhagyás végett bemutatni szíveskedjék. Ugyanakkor azt is jelentse, miből szándékozik fedezetet találni a gyüjtésen kívül a kápolna építésre, s kikre számít, hogy adományaikkal a gyüjtést támogatni fogják, mert csak komolynak ígérkező akciót szabad elindítani." ${ }^{126}$ A kezdeményezés rövid idő alatt elhalványult, s Bojárhalmon soha nem épült templom vagy kápolna.

Csánky Dezső festőművész, a Szépművészeti Múzeum főigazgatója ${ }^{127} 1939$ végén írt Balogh páternek, s arra kérte, hogy egy müvészcsere-program keretében fogadjon külföldi alkotót. Balogh 1939. december 5-én kelt - az akkor már a részben a tulajdonában lévő Délmagyarország cégjelzéses papírjára írt -válaszában megköszönve a fölkérés így fogalmazott: „,készséggel támogatom a Méltóságod által bölcsen vezetett kulturális csereakciót és szívesen látok vendégül külföldi müvészt. Miután plébániám az ország legnagyobb tanyai plébániája, azt hiszem leginkább festőművészt érdekel az alföldi táj, a tanyai házak, az udvarok, stb. A külföldi müvész személyére nézve semmiféle feltételem nincs, bárkit szívesen látok."128

\footnotetext{
125 SZCSPL PHEI 2950/1939.

126 SZCSPL PHEI 2950/1939.

${ }^{127}$ Csánky Dénes (1885-1972) festőművész, művészeti író, múzeumigazgató. Művészeti tanulmányait a budapesti Iparművészeti Iskolában és a müncheni Festészeti Akadémián végezte. 1910 és 1912 között a Mủemlékek Országos Bizottságának titkára, 1912-től 22-ig a Fővárosi Múzeumok igazgatóhelyettese. 1935 és 1944 között a Szépmúvészeti Múzeum föigazgatója volt. 1938-ban megkapta a Corvin-koszorút. 1945-tól 1949-ig Németországban, majd onnantól haláláig Brazíliában élt. Eleinte zsánerképeket festett, későbbi korszakában inkább tájképeket.

${ }^{128}$ OSZK KT Fond 191/40.
} 
Nem tudjuk, hogy végül érkezetett-e Szeged-Alsóközpontra müvész a csereakció keretében (bár valószínü, hogy a háború miatt feszült európai politikai helyzetben, nem). Csánky Dénes és a Balogh István kapcsolatának különös vonása, hogy Csánkyt 1944-ben a lefoglalt zsidó tulajdonban lévő műkincsek kormánybiztosává nevezték ki, aki aztán 1944 végén a Szálasi-kormány utasítására megszervezte és végrehajtotta a Szépmüvészeti Múzeum anyagának és más magyarországi mükincseknek a Németországba szállítását. Nem sokkal később Balogh páter, már mint az Ideiglenes Nemzeti Kormány tagja, az Elhagyott Javak Kormánybiztosságának felügyelőjeként szintén jobbára a deportált - és onnan többségében vissza nem tért - zsidóság vagyonát felügyelte.

\section{5. Vita a főispánnal, lelkipásztori feladatok az 1940-es évek első felében}

1942 tavaszán Balogh István Tukats Sándorral, Szeged szabad királyi város főispánjával keveredett vitába. A páter az 1942. február 28-i városi közgyülésen bírálta a szegedi közellátást, amelyben szerinte nem szociális, hanem politikai szempontok érvényesülnek. Ezt a véleményét az Alsótanyai Gazdasági Egyesület 1942. március 1jei választmányi ülésén is kifejtette. A közellátás nehézségeiért - nem megnevezve, hanem csak utalva személyére - a föispánt tette felelőssé. Tukats Sándor ezért előbb Glattfelder Gyula püspökhöz, majd Szinyei Merse Jenő vallás- és közoktatásügyi miniszterhez fordult.

A föispán audiencián jelent meg a csanádi püspöknél, akitől Balogh István rendreutasítását kérte, és fegyelmi eljárást javasolt ellene. Glattfelder az ügyről írásos anyagot kért. Tukats ezt nehezményezte, véleménye szerint ugyanis ő csak elöljáróinak - a kormány képviselőinek - tartozik jelentési kötelezettséggel. ${ }^{129}$ A föpap ezért levelet írt neki, amelyben kitartott az írásos jelentés kérése mellett, ugyanakkor papja mellett is kiállt. „Nagy figyelemmel vártam Méltóságod beígért sorait, amelyek hivatva volnának dr. Balogh István plébános úr részéről Méltóságoddal szemben történt sérelmek felvilágosítására, hogy annak alapján járjak el vele szemben. Nagy meglepetéssel

\footnotetext{
${ }^{129}$ SZCSPL PHEI 689/1942.
} 
értesültem azért a tegnapi nap folyamán Raskó Sándor püspöki helynök úrtól, hogy Méltóságod állítólag nehezményezi, hogy én írásos közlést kívántam volna a történtekről, ami csak hivatali felsőbbséggel szemben fennálló kötelesség..."130

Glattfelder Gyula kifejtette, hogy a törvényhatóságon, vagy más közéleti fórumon elhangzott mondatok nem tartoznak a hatáskörébe. Ö - mint püspök - csak a hitbeli és egyházigazgatási kérdésekben elöljárója Baloghnak, aki politikusként vagy újságíróként szabadon cselekedhet - amíg az egyház érdekeit szem előtt tartja, illetve a katolikus közélet jeles személyiségeit nem támadja. Kellö, alapos ismeretek hiányában, megalapozottság nélkül nem akarja papját fegyelmi eljárásnak alávetni. Ezután rámutatott: „Én mindig a legnagyobb lojalitással ismertem el Méltóságod hivatali buzgalmát $\mathrm{s}$ ha bármely papom csak látszatát is szolgáltatta annak, hogy munkáját megnehezíti, a legrövidebb úton figyelmeztettem, akár törvényes, akár morális kötelességére talán hibáján túlmenőleg is, mert súlyt helyezek rá, hogy e mai nehéz időben az összes hivatali fórumok harmóniában éljenek $\mathrm{s}$ kölcsönös megértéssel szolgálják a köz ügyét. Azonban azt, hogy tudjam, mért kell marasztaló ítéletet kimondanom, talán mégis csak szabad igényelnem? Ha tehát Méltóságod Magát személyében sértve vagy a köznyugalmat fenyegetve látná Balogh részéről, szíveskedjék az adatokat tudomásomra hozni, mert a Méltóságoddal szemben érzett igen nagy tiszteletem és bizalmam tiltja föltételeznem, hogy nem elég informált helyzetben méltóztatott tőlem ítéletet várni, amire semmiképp sem vagyok kapható."131

Tukats 1942. március 7-én írt a föpapnak, s a jelentés késlekedéséről számolt be. Nemcsak a törvényhatósági bizottság közgyülési jegyzökönyve és a rendörség jelentése, hanem fültanúk meghallgatása alapján írja meg kifogásait - így konkrét adatokkal bőven alátámasztva: „A rendőrség jelentésén kívül olyan személyiségektől is szándékom információkat szerezni, akik az alsótanyai Gazdasági Egyesület választmányi ülésén részt vettek és dr. Balogh István plébános úr felszólalásának fültanúi voltak. Úgy hiszem, az ügy objektív megvilágítását az ilyen módon szerzett adatok elősegítik."132

A föispán négy nappal később, március 11-én részletes beszámolót küldött a püspöknek, amelyben részletezte Balogh közgyülési fölszólalását. Ebben olvashatjuk: „Dr. Balogh István Szeged-alsóközponti plébános úr, törvényhatósági bizottsági tag az

\footnotetext{
${ }^{130}$ SZCSPL PHEI 689/1942.

${ }^{131}$ SZCSPL PHEI 689/1942.

${ }^{132}$ SZCSPL PHEI 689/1942.
} 
1942. évi február hó 28-án tartott közgyülésen a polgármesteri jelentéshez hozzászólva, közellátási kérdéseket tett kritika tárgyává, többek között azt mondotta, hogy a közellátásban politikai szempontok érvényesülnek. Mivel ez a megjegyzése semmilyen reális alappal nem bír és alkalmas arra, hogy részrehajlással gyanúsítva az intéző hatóságot, tájékozatlan emberek között zavart keltsen, az elnöki székből figyelmeztettem a törvényhatósági bizottsági tag urat, hogy tartózkodjon az ilyen megjegyzésektől, mert a közellátást illetőleg egyetemes országos érdekek az irányadók." 133

Tukats Sándor leírta - a rendőrség által kiküldött megfigyelő jelentése alapján, valamint néhány jelenlévő megkérdezése után - a plébánosnak a Gazdasági Egyesület ülésén megfogalmazott észrevételeit is. „Az alsótanyai Gazdasági Egyesület 1942. március hó 1-én választmányi ülést tartott. A m[agyar]. kir[ályi]. rendőrség szegedi kapitányságának jelentése szerint ezen felszólalt dr. Balogh István Szeged-alsóközponti plébános is, aki beszédében többek között a következőket mondotta:

A./ Kitért a közgyülésen történt eseményekre s hangoztatta, hogy ő csak az igazat mondotta, stb.

B./ »Igen nagy a nyomor, nem az számít, hogy nincsen az állatoknak takarmány, hanem az, hogy a tömegnek nincs kenyere.«

C./ »Rendőrségi székház, paprika beváltó és más épületek várhattak volna, elégítsék ki előbb az árvízzel sújtott tanyaiak téglaszükségletét, « stb.

D./ Beszéde során a következő további kijelentést tette: »Igaz, hogy akinek az Isten rangot adott, annak észt is adott hozzá, de nem elég a rang és ész, nem kell azt hinni, hogy mindent tud. Aki a tanyai bajokat meg akarja tudni és abban intézkedni - és pedig nem önkényesen - az megbeszéli a tanyai vezetőkkel a teendőket. Hol van itt a népi politika« stb." 134

A föispán a levél végén aggályainak adott hangot. Az egyház és az állam tisztségviselőinek vitája nem tesz jót, beárnyékolja ugyanis kapcsolatukat, és a közvélemény elött is a nézetkülönbség látszatát kelti. Tukats kifejtette, hogy azért vonakodott a levél megírásától, mert az azt a látszatot kelti, mintha a föispán magyarázkodásra szorulna az alsóközponti plébános - szerinte alaptalan - vádjai miatt.

\footnotetext{
${ }^{133}$ SZCSPL PHEI 689/1942.

${ }^{134}$ SZCSPL PHEI 689/1942.
} 
„Mint katolikus ember nem tartom helyén valónak, hogy nyilvánosság előtt az Egyház lelkipásztorával olyan vitába szálljak, amely vita tájékozatlanok és kellő műveltséggel nem bírók előtt alkalmas arra, hogy az Egyház funkcionáriusának, de a világi hatóságnak is a tekintélyét rontsa és megrendítse azt a hitet, bizalmat, melyet az intéző hatóság méltán elvár, ha a munkáját becsületesen és felelősséggel végzi. Öszintén megmondom, voltak aggályaim, hogy jelen levelemben elmondottak talán annak a látszatával bírnak, hogy tulajdonképpen a föispán igazolja magát dr. Balogh István plébános úr elött, azonban mindezeken túltéve magam, a három éves föispáni müködésem minden ténykedéseiért - melynek nincsenek takarni való részletei - a felelősséget vállalva, nyugodtan állok Nagyméltóságod általam mindenkor tisztelt, fennkölt Személye előtt; átnyújtva e sorokat, az ügynek pártatlan megítélést kérve."135

A levélben szereplö adatok fényében Glattfelder 1942. március 16-án írt Baloghnak.

„Szeged város főispánja panaszt emelt előttem Tisztelendőségeddel szemben, hogy a városi közgyülésen alaptalan vádakkal és invektívákkal ${ }^{136}$ illette a hatóságot $\mathrm{s}$ nevezetesen a föispán urat is, de föleg azért, hogy az alsótanyai gazdakörben oly politikai beszédet mondott az ott egybegyült nép előtt, mely alkalmas nemcsak a hatóság tekintélyét lejáratni, hanem a köznyugalmat is veszélyeztetni, ami a jelen tragikus körülmények között a legsúlyosabb kritikát hívná ki Tisztelendőségeddel szemben, amikor a nemzet harcban áll, s minden egyházi és polgári fórum a belső fegyelem fenntartását szorgalmazza."137

A püspök figyelmeztette papját, hogy közéleti és újságírói tevékenysége pontosabban annak „kötekedő” modora - sok kritikát vált ki, elsősorban a városi vezetők körében, akik pedig mindig támogatták a katolikus egyházat és együttmüködtek a klérussal. Glattfelder kiemelte, hogy a háború idején, feszült közhangulatban a papságnak a kormányzat mellett kell kiállni. „Ismételten figyelmeztettem Tisztelendőségedet, hogy az a kötekedő modor, amellyel közéleti ténykedését szóban és sajtó útján végzi, igen éles kritikát hí ki vele szemben, $\mathrm{s}$ ha netán egyesek ennek folytatását szorgalmazzák, a komoly intéző körök fennakadnak rajta $\mathrm{s}$ Tisztelendőségeddel szemben minden lehetséges erkölcsi megtorlást igénybe fognak

\footnotetext{
${ }^{135}$ SZCSPL PHEI 689/1942.

${ }^{136}$ Invektíva = éles támadás, kirohanás valaki ellen.

${ }^{137}$ SZCSPL PHEI 689/1942.
} 
venni, különösen, hogy a mai közhangulat előtt kihasználható körülmények is segédkezet nyújtanak nekik." 138

A föpásztor kérte Baloghtól, hogy nyilvánosság előtt - a Délmagyarország címü lap hasábjain - jelentse ki, hogy sem a föispánt, sem a „hatósági tekintélyt” nem akart megsérteni, lejáratni. Lehetőleg pedig fejezze be közírói tevékenységét. Ezzel ugyanis fölösleges indulatokat szít maga ellen, s lelkipásztori teendőit sem tudja kielégítően ellátni. „Jó volna, ha ily értelemben a befolyása alatt álló sajtótényezőket informálná, bár leghelyesebben akkor járna el, ha ez utóbbival minden nem hivatalos kapcsolatot is megszakítana, annál is inkább, mivel a jelen körülmények között a hívek gondozása a lelkipásztornak annyi munkát juttat, hogy politikai vagy közéleti polémiákra ideje sem lehet, ha feladatát becsülettel kívánja betölteni."139

1942. december 30-án a vallás- és közoktatásügyi minisztérium egyik tanácsosa írta a csanádi egyházmegye püspökének Balogh páterről: „Dr. Balogh István SzegedAlsóközponti róm[ai]. kath[olikus]. plébános nem tengelybarát, ki nemzeti szempontból káros meggyőződésének - bár igen óvatos formában - állandóan hangot ad $\mathrm{s}$ környezetét, valamint híveit e tekintetben a legmesszemenőbben befolyásolni igyekszik. A 12. 000 lelket kitevő híveit a paraszt akadémiákon arról akarta meggyőzni, hogy a németek a háborút nem nyerhetik meg s a végső győzelem az angoloké lesz. Ezen kijelentéseivel a népben a bizonytalanság érzését kelti, mellyel a magyar állam fegyveres erejének hátrányt, az ellenségnek pedig előnyt okoz.

Dr. Balogh plébános zsidó származású, ki az 1939. IV. tc. 1. § 2. bekezdésének 8. pontja értelmében zsidónak nem tekinthetö ${ }^{140} \mathrm{~s}$ így Szeged városi törvényhatósági bizottsági tagságát is megtarthatta. Szeged város polgármestere tanúsítványt is kiadott részére, mely félzsidó származását bizonyítja.

Dr. Balogh hivatali ténykedéseinek háttérbe szorításával - 3 káplánja dolgozik inkább üzleti ügyekkel foglalkozik, úgymint a »Délmagyarország« címü napilap alapítója, majd társtulajdonosa, angóra nyúltenyésztés, majd pedig a szegedi szabadtéri színjátékok aktív szereplője, mely sokoldalú elfoglaltsága papi hivatásától elvonja."141

\footnotetext{
138 SZCSPL PHEI 689/1942.

${ }^{139}$ SZCSPL PHEI 689/1942.

${ }^{140} \mathrm{Az}$ idézett - a zsidók közéleti és gazdasági térfoglalásának korlátozásáról szóló - törvényhely: „Amennyiben a jelen törvény másképp nem rendelkezik, rendelkezéseit nem lehet alkalmazni [...] arra, aki keresztény hitfelekezetnek tényleges vagy nyugdíjas lelkipásztora.”

${ }^{141}$ SZCSPL PHEI 148/1943.
} 
A levélre 1943. január 25-én válaszolt - a nagybeteg Glattfelder Gyula helyett Raskó Sándor nagyprépost, püspöki helynök, aki védelmébe vette Baloghot, s tételesen igyekezett cáfolni a fölmerülő vádakat. Azt azonban leszögezte, „...ha híveit nemzeti szempontból - akármilyen formában - károsan megpróbálná befolyásolni, sőt ebben az esetben csak figyelmeztetéssel be sem érném." ${ }^{142}$ Raskó sorai mögött nem föltétlenül a Balogh iránti szimpátiát kell keresnünk. Valószínűbb, hogy a püspöki helynök az egész ügyet az egyház belső ügyének tekintette, s a miniszteri tanácsos ilyen szigorú hangnemü - és egyértelmüen antiszemita töltésü - levelét illetéktelen külső beavatkozásnak tartotta.

„Anélkül azonban, hogy Balogh plébános úr védelmében hivatalos vizsgálat előtt vagy annak mellőzésével már most állást kívánnék foglalni, szükségesnek tartom a következő helytnemálló állításokra felhívni Nagyméltóságod figyelmét."143 - írta Raskó Sándor, aki a továbbiakban öt pontba szedve pontosította, illetve cáfolta meg a minisztérium munkatársának információit.

Először leírta, hogy Balogh nem tart „parasztakadémiákat”, és amikor tartott is, csak a hatósági rendeleteket ismertette és magyarázta. „Balogh plébános kb. egy éve már nem tart »parasztakadémiákat« s azokon tehát káros befolyást nem gyakorolhatott. Amikor tartotta, azért tette, mert a hatósági rendeleteket ismertette, s ezzel a mai nyugtalan időben sok félreértésnek vette elejét. Mióta azonban plébániáján, épen az ő sürgetésére, felállították a tanyai közigazgatást, ezt a munkát nálánál avatottabb és hivatottabb tisztviselők végzik." 144

A püspöki helynök levelének második pontjában visszautasította, hogy a plébános helyett három segédlelkész dolgozna. Szeged-Alsóközponton ugyanis csak két káplán szolgál, akik közül az egyik katonai szolgálatot teljesít. „Annak a vádnak, hogy Balogh plébános helyett 3 káplánja dolgozik, már csak azért sincsen alapja, mert Szeged-alsóközponton soha sem volt 3 segédlelkész, csak kettő; ebből is már jó ideje az egyik katonai szolgálatot teljesít." Határozott - majdhogynem ironikus - hangnemben írta, hogy „,..az ügy érdekében álló volna, ha Nagyméltóságod felhívná az informátor urat, nevezze meg azt a három káplánt, aki egyidöben dolgozott az alsóközponti plébánián és pedig Balogh plébános helyett."

\footnotetext{
142 SZCSPL PHEI 148/1943.

143 SZCSPL PHEI 148/1943.

144 SZCSPL PHEI 148/1943.

145 SZCSPL PHEI 148/1943.
} 
Raskó Sándor kitért az alsóközponti lelkész újságírói és szerkesztői tevékenységére is, amelyet egy ideje nem gyakorol - éppen a püspök kérésére. „A Délmagyarországgal való kapcsolatát sokan tényleg kifogásolják, mivel a plébános úr tollforgató ember, $\mathrm{s}$ ha bárki támadást vezet ellene, mindenkor helytáll. $\mathrm{Ha}-$ mint újságírót - kifogás érheti, az legföljebb az, hogy a nevezett lap valamikor a liberálisok szócsöve volt, de épen Balogh szerezte meg a lapot a keresztény irányzat számára, persze hiába, mert ellenfelei - talán túlságos ellenzékieskedése miatt - »neophitának « ${ }^{146}$ tartják."

A negyedik pontban a levél írója nem tartja kifogásolhatónak, hogy a páter nyulakat tenyészt. Sőt, szerinte ezzel saját - és az egyház - anyagi helyzetét javítja, s híveinek új gazdasági lehetőséget, jó példát mutat. „Ami az angóranyúl - helyesebben belganyúl - tenyésztést illeti, mert angóranyúlai nincsenek, ez nem lehet vád, mert ezzel minden pap foglalkozhatik, különösen, ha erre anyagi szempontból rá van utalva; azonfelül ezzel híveinek is olyan új gazdasági tevékenységre kíván jó példával és buzdítással szolgálni, mely - főként ma - rendkívül jövedelmezőnek bizonyul."148

Raskó Sándor az utolsó pontban kifejtette, hogy Balogh István soha nem „szerepelt” a szegedi szabadtéri játékokon, mindössze az első két rendezvény szervezésében vett rész. „A szegedi szabadtéri játékoknak Balogh soha nem volt »aktív szereplője«. Igaz, hogy az első kettő létrejövetelében kezdeményező és annak megrendezésében társulási alapon szervező volt; a harmadikat már nem rendezte..."149

A nagyszámú és elszórtan élő tanyai lakosság lelki ellátása nagy problémát jelentett. Ezért Balogh István örömmel vette, hogy a jezsuita rend szegedi rendházában élő - pappá szentelt, de még tanulmányaikat folytató - szerzetesek részt vennének a pasztorálásban. A tanyákon nem volt minden központban templom, vagy kápolna, ezért az állami tanyai iskolákban alakítottak ki miséző helyeket. Az oda vasárnapra kiszálló papok az egész napot híveikkel töltötték. Délelött misét mondtak, délután gyerekeket oktattak hittanra, foglalkoztak a leventékkel, a KALOT és a KALÁSZ tagjaival, valamint családlátogatást végeztek.

1941. szeptember 2-án Balogh a következőket írta az egyházmegyei hatóságnak. „Egyik tanítóm jelentette, hogy a jézustársasági atyák az idén bőven rendelkeznek

\footnotetext{
${ }^{146}$ Neofita = valamely vallás vagy tan követésére újonnan áttért személy.

147 SZCSPL PHEI 148/1943.

148 SZCSPL PHEI 148/1943.

149 SZCSPL PHEI 148/1943.
} 
páterekkel, akiket szívesen küldenének ki a tanyára állandó jelleggel. Így megígérte a Házfőnök Úr, hogy a Királyhalom-i iskolánál, minden hónap második vasárnapján sz[en]t. misét mondanak és prédikálnak. Állítólag hasonló ígéretet tettek volna a bojárhalmi iskola részére is. Bár két segédlelkészem van, örömmel veszem ezt az értesülést, mert hála Istennek, az igények annyira növekednek, hogy azokat hárman sem tudjuk kielégíteni."

1941. szeptember 13-án Borbély István jezsuita házfönök írt a püspöknek. Kijelentette, hogy azok a fölszentelt pap rendtagok, akik még föiskolai stúdiumaikat végzik örömmel vesznek részt a tanyai hívek lelki ellátásában. A szerzetesek csak nyolc-tíz hónapig maradnak a fölszentelés után Szegeden, és létszámuk is változó, ezért a kisegítés ügyében állandóan egyeztetésre van szükség. A jezsuiták mindig a plébános tudtával és utasítása szerint mennek ki misézni, díjazásuk pedig csak az útiköltség összege.

„A kérdéses tanyai kisegítéseket házunk azon tagjai szokták végezni, akik felszentelésük után még egy évig főiskolánkon folytatják tanulmányaikat. E miatt a kiszállások mindig szerény és korlátozott keretek között történnek. Legfeljebb tíz hónapig tarthatnak, s mindig az itt tartózkodó felszentelt teológusok számától függ, hogy hány helyen vállalhatunk ilyen munkát. S hogy e kiszállások a tanulmányok folytatását nem gátolják, rendi elöljáróim többször megismételt szigorú utasításai szerint csak olyan kisegítéseket szabad elfogadnunk, melyek a sz[ent]. mise és valamely egyszerü hitelemző beszéd elmondását nem haladják túl. Ellenkező esetben a teológusok nem küldhetők ilyen kisegítésre. Mindenkor kötelességünknek tartottuk, hogy e kiszállások teljesen az illetékes plébános akarata és utasításai szerint menjenek végbe. Ha véletlenül nem a plébánia jelentkezett ilyen igénnyel, a kérelmezőknél mindig tudakozódtunk, vajon a plébános tudta és beleegyezésével járnak-e el. Ezt a jövőben is mindenkor megtesszük." ${ }^{\prime 151}$ - fogalmazott a jezsuiták szegedi házfőnöke.

A jezsuiták tanyai kisegítő tevékenysége azonban problémákat okozott a helyi plébánosnak. A szerzetesek ugyanis csak az útiköltséget (két pengő) kérték a szentmiséért, míg a világi papok a megállapított stóladíjat várták (tizenöt-húsz pengö). Gyakran az is előfordult, hogy a hívek - a lelkész megkerülésével - egyesen a jezsuitáktól kértek miséző papot, éppen az alacsonyabb díjazás miatt.

\footnotetext{
${ }^{150}$ SZCSPL PHEI 2597/1941.

${ }^{151}$ SZCSPL PHEI 2597/1941.
} 
A kialakult felemás helyzetről Balogh István 1943. október 18-án számolt be a püspöknek. Ismertette, hogy a világi papok - föleg a segédlelkészek - rossz anyagi körülmények között élnek. Ezért nagy szükségük van a stóladíjakra, amit azonban hiába várnak, hiszen a tanyaiak szívesebben hívják inkább az „olcsó” jezsuitákat: „A tanyai plébániák egy része állandóan rászorul arra, hogy a jézustársasági atyák, különösen a szentmisék szolgáltatásával, segítségükre legyenek. Vannak helyek, mint pl. a Zöldfásiskola vagy a Balog-iskola, ahová rendszeresen járnak ki ezek a jó páterek. Kiszállásukért csak a vonatköltséget kérik a hívektöl. Ezzel a plébániák, különösen a kiszálló segédlelkészek, rendkívül kényelmetlen helyzetbe jutnak. A jézustársasági atyák nem szorulnak arra rá, hogy a Főtisztelendő Egyházmegyei Hatóság által megállapított, esetleg a mostani rendkívüli gazdasági viszonyok miatt a felemelt stólát kérjék, a világi papság azonban, különösen a segédlelkészek, igenis a nyomor szélén vannak; annyi legális jövedelmük sincs, hogy öltözetüket pótolni tudják. Van olyan plébános, akinek komoly háztartási gondjai vannak. A világi papság tehát nem mondhat le a stólájáról. De mit gondoljanak, és mit mondjanak a hívek, ha azt látják, hogy a plébániáról a papok 15-20 pengőért, - ami nem teszi ki egy pár csirke árát sem, - teszik meg az utat és szolgálatot, ugyanakkor a jézustársasági atyák 2 pengőért? Ismételten megtörtént, hogy amikor misét kértek valamely iskolához, jezsuitát kértek mondván, hogy az ingyen jön, a tisztelendő urak pedig pénzért jönnek."152

Németh Béla jezsuita szerzetes 1943. október 26-án kelt levelében kifejtette, hogy amióta a jezsuiták kisegítő lelkészi teendőket látnak el, soha nem kértek honoráriumot az útiköltségen fölül. Ez Loyolai Szent Ignác szellemiségéböl és rendjük regulájából fakad: munkájukat, hivatásukat nem meghatározott ellenszolgáltatás fejében végzik. „A pátereink több mint húsz éve végeznek kisegítő lelkipásztori munkát a csanádi egyházmegyében és ezen idő alatt a honorárium tekintetében mindig ugyanazt az elvet vallották, amit vallanak ma is rendünk szellemében, hogy minden nagylelkü adományt hálásan fogadunk, azonban jogunk semmiféle ellenszolgáltatáshoz nincs az útiköltségen felül. Ha már most ebből a mi eljárásunkból kifolyólag egyenetlenségek állnak elő, ezeknek rendezése a plébános urakra, illetőleg az egyházmegyei hatóságra tartozik, annál is inkább, mert hiszen mindenki tudhatja, hogy mi milyen feltételek mellett vállaltuk a kisegítést."153

\footnotetext{
${ }^{152}$ SZCSPL PHEI 2680/1943.

${ }^{153}$ SZCSPL PHEI 2680/1943.
} 
Raskó Sándor apostoli kormányzó 1943. október 27-én értesítette Krämer Tamás kisteleki esperesplébánost - akinek esperesi kerületéhez tartozott a szegedi tanyavilág a jezsuiták álláspontjáról: „Azt is meg kell érteni, hogy a szegedi jézustársaságiak ragaszkodnak reguláik elöírásaihoz, s nem hajlandók csakis a hívek által felajánlott összeget mint alamizsnát elfogadni a készkiadásaikon kívül."154 Ugyanakkor szükségesnek tartotta egységes stóladíjak kialakítását - vagy az esperes, vagy a püspöki hivatal hatáskörén belül - az ilyen félreértések és vádaskodások elkerülése miatt.

Krämer esperes 1943. december 11-én írta meg az apostoli kormányzónak, hogy az esperesi kerületi gyülésen megállapították az egységes stóladíjakat. Így a miséző helyre való kiszállás díja 20 pengő, amit a plébánosnak kell kifizetni. „...az ügyet őszi koronánkon az összes tanyai papok jelenlétében tárgyaltattam le, amikor is úgy határoztak, hogy a kiszállás díja 20 (Húsz) pengő lesz. Ezt az összeget a plébánosok szedik be és ők adják át a kiszálló papoknak, a főtisztelendő jezsuita pátereknek is."155

1941 végén - a világháború eseményeinek hatására és az ország esetleges hadszíntérré válásának lehetőségét szem előtt tartva - a honvédelmi minisztérium előírta leánylevente csapatok szervezését és kiképzését. A csapatokat önkéntes jelentkezőkből kellett megalakítani. A foglalkozásokon a leányleventék nem katonai jellegü, és nem pusztán fizikai kiképzésében részesültek. Vallás- és erkölcstani, háztartási ismereteket sajátíthattak el, valamint testi erőnlétfejlesztő gyakorlatokat végeztek. Ezzel készülve a magyar anya szerepére.

Bár a belépés nem volt kötelező, az alsóközponti tanyavilágban a lányok nagy része mégis behívót kapott a helyi levente parancsnok aláírásával. Balogh plébános bizonyára hívei kérésére - levélben érdeklődött a püspöki hivataltól, hogy kötelező-e a leánylevente mozgalomban részt venni. 1942. január 23-án - az alsóközponti lelkészi hivatal jelzete szerinti - 40/1942. számmal így írt: „A Magyar Katolikus Akció legutóbbi számában azt olvashattuk, hogy a leánylevente-kötelezettség csak f[olyó]. évi szeptember 1-étől kezdődőleg lép érvénybe. Ennek dacára a tisztelettel mellékelt 3 $\mathrm{d}[\mathrm{a}] \mathrm{r}[\mathrm{a}] \mathrm{b}$ idézés tanúsága szerint igen szigorú hangú behívót kapnak a lányok."156

Glattfelder Gyula Mihalovics Zsigmondtól, az Actio Catholica országos elnökétöl 1942. január 29-én kelt levelében kért fölvilágosítás az ügyben. A válaszlevelet február 6-án írta Mihalovics pápai prelátus, miután Béldy Alajos

\footnotetext{
${ }^{154}$ SZCSPL PHEI 2680/1943.

${ }^{155}$ SZCSPL PHEI 2680/1943.

${ }^{156}$ SZCSPL PHEI 324/1942.
} 
altábornaggyal - a honvédelmi minisztérium leventemozgalommal foglalkozó tisztségviselőjével - konzultált. „Sajnos, Béldy minden jó szándéka ellenére is azt tapasztaljuk, hogy az alantas Levente-közegek nem az altábornagytól kiadott irányelvek szerint dolgoznak. A leánylevente egyesületeket országszerte derüre-borúra alakítják, nem egy helyen kényszerítő eszközök alkalmazásával. Természetesen, felfelé azt jelentik, hogy a leányok önként jelentkeztek."157 - olvasható Mihalovics levelében.

A prelátus egyben kifejtette Serédi Jusztinián hercegprímás, esztergomi érsek véleményét is a leánylevente mozgalomról, illetve az annak szabályozására irányuló törvénytervezetről. Az ország első katolikus főpapja nem látta értelmét a mozgalomnak, a lányok ugyanis - szerinte - az iskolában hittan órán és testnevelés órán megkapják a szükséges képzést, a háztartás vezetését pedig családjukban, otthonukban sajátítják el. Mihalovics a következőképpen fogalmazta meg Serédi álláspontját. A hercegprímás „...úgy látja, hogy a leánylevente intézményre semmi szükség sincsen, mert a célt, t[udni]. i[llik]. a magyar leányifjúság magyarrá neveltessék, továbbá valláserkölcsi és honvédelmi testi neveléssel, valamint háztartási oktatással készüljön a magyar anya szerepére, külön leánylevente szervezet nélkül eddig is nagy részben elérte a családi, a templomi és iskolai valláserkölcsi nevelés, az iskolai oktatás és testnevelés, végül a családban és külön tanfolyamokon adott háztartási kiképzés."158

Az alsótanyaiak által kapott „behívók” érvénytelenségét és szabálytalanságát mutatja, hogy Béldy altábornagy már 1941. november 18-án kiadott rendeletében a női levente szakosztályok szervezését - további intézkedésig - megtiltotta. A rendeletben ismertette a leánylevente csoportok szervezése kapcsán fölmerülő problémákat, félreértéseket. Legnagyobb gondnak a kényszer alkalmazását tekintette, a szervezők ugyanis gyakran kötelező jellegünek állították be a mozgalmat. „...egyes helyeken állítólag mégis az összes leányokat - még a tanintézetek kötelékébe tartozókat is szinte belekényszerítették a női szakosztályokba, s ezzel máris ellenszenvet keltettek a jövőben törvény alapján megszervezendő női leventeintézmény iránt."159 A fötiszt problémaként fogalmazta meg továbbá, hogy a lányokat gyakran katonai jellegü kiképzésnek vetik alá és csoportjaik élén gyakran férfi leventeparancsnok áll. Ezért határozta el a következőket: „A fenti visszásságok megszüntetésére általánosságban

\footnotetext{
${ }^{157}$ SZCSPL PHEI 324/1942.

158 SZCSPL PHEI 324/1942.

${ }^{159}$ SZCSPL PHEI 324/1942.
} 
elrendelem, hogy további intézkedésemig a női szakosztályok ideiglenesen szüntessék be müködésüket."160

Az altábornagy kivizsgálta a Balogh István által jelentett szeged-alsóközponti ügyet. 1942. május 30-án írta Mihalovics Zsigmondak, hogy: „Magam is úgy gondolom, hogy a jelentett esetekben alárendelt közeg ügyetlenségéröl van szó, s nem a vezetőség célzatosságáról, egyébként intézkedés történt, hogy a szegedi leventevezetőség a kényszerü behívásokat szüntesse meg."161

„A megidézett leányokat - bár az idézőket a körzetparancsnok írta alá - nem a körzetparancsnok, hanem a rúzsajárási áll[ami]. elemi iskola tanítónője, a női szakosztály vezetője, fogadta." ${ }^{162}$ - derült ki. A félreértés abból fakadt - legalábbis Béldy értelmezése szerint -, hogy a rúzsai tanítónő női levente szakosztályt akart szervezni. Az kezdeti érdeklődés azonban hamar alábbhagyott, mert a lányokat azzal ijesztgették, hogy tavasszal a frontra küldik őket. A tanítónőt pedig azzal vádolták, hogy ügybuzgóságának indoka a lányonként és foglalkozásonként kapott egy pengős díjazás. Mivel egyik állítás sem volt igaz, saját maga tisztázása miatt idézte be a lányokat egy foglalkozásra, amelyre a „behívót” - a nyomatékosítás végett - a körzeti leventeparancsnokkal íratta alá. Béldy végköveztetése: „...a tanítónő teljes jóhiszeműséggel járt el. Hibázott a leventeparancsnok azzal, hogy az aláírt idézőt a szakosztályvezető rendelkezésére bocsátotta s azzal a dolognak olyan színezetet adott, mintha a leventeegyesület női szakosztályában való jelentkezés kötelező volna.”163

Balogh István 1944. június 21-én, 224/1944. számú levelében jelentette a püspöki hivatalnak, hogy az alsóközponti plébánián - a püspök április 27-i rendeletének megfelelően - megválasztották az egyházközségi képviselőtestület tagjait és póttagjait. Ezzel megalakult az új képviselőtestület, amelynek mandátuma 1947. június 1-jén tehát már Balogh páter távozása után - járt le.

A plébánia, lelkészség a püspökség területi egysége. Az egyházközség azonban ennél bővebb fogalom; alatta hagyományosan a helyi hívek összességét értjük hierarchikus szervezettségtöl függetlenül. A Magyar Katolikus Püspöki Kar 1938. október 4-én hagyta jóvá az (1984-ig érvényes) egységes egyházközségi igazgatási és adózási szabályzatot, ami magyar és német nyelven jelent meg (a németnyelvű katolikus

\footnotetext{
${ }^{160}$ SZCSPL PHEI 324/1942.

${ }^{161}$ SZCSPL PHEI 324/1942.

${ }^{162}$ SZCSPL PHEI 324/1942.

${ }^{163}$ SZCSPL PHEI 324/1942.
} 
egyházközségek miatt). Ebben az egyházközséget a következőképpen határozták meg: „...egy plébánia híveinek szervezett összessége, akik a helyi plébános vezetése alatt az előírt szabályzat szerint választott képviselőtestület útján bizonyos helyi egyházi ügyek intézésében részt vesznek, önálló joghatósággal azonban nem bírnak s minden választás vagy határozat csak az egyházi hatóság jóváhagyása után lesz jogérvényes." ${ }^{164}$ A két világháború közötti egyházközségek célja a helyi hívek aktivizálása volt, szerepük tanácsadó testületi jellegű. (1992 óta a kánonjog szerint az egyházközségek nem a plébániától különböző jogi személyek.)

A püspök áprilisi rendeletének értelmében a jelölőbizottság összeállította a jelöltlistát. A jelöltnévsor összeállításakor Balogh plébános ügyelt arra, hogy a képviselőtestületben ,...a hívek foglalkozásuk arányában nyerjenek képviseletet és a plébánia legtávolabbi része is képviseletet kapjon."165 Ez a korabeli testületekben általános volt. Így például a több nemzetiség által lakott településeken az etnikai arányoknak megfelelő számban kerültek ki a tagok. Egyházi elnök Balogh István volt. Világi elnökké Wagner Gyula fölbirtokost, alelnökké Varga Mátyás népiskolai igazgatót, jegyzővé Dosztig Ferenc tanítót választották. A tagok nagy része gazdálkodó volt, de kisbérlők, tanyai tanítók és iskolaigazgatók is helyet kaptak a testületben.

A 12000 hívőt magában foglaló alsóközponti plébánia képviselői a következők lettek: dr. Árendás György városi aljegyző, Babarczi József gazdálkodó, Balogh Antal gazdálkodó, Bába János gazdálkodó, Bálint János kisbérlő, Bózsó Ferenc gazdálkodó, Benke Ferenc mezőgazdasági iskola igazgatója, Császár Rudolf gazdálkodó, Dobó Ferenc gazdálkodó, Dobó István gazdálkodó, Dobó János gazdálkodó, Farkas János gazdálkodó, Fraunhoffer Mihály hentes, Kazi Gáspár anyakönyvvezető-helyettes, Kiri István gazdálkodó, Kószó Imre gazdálkodó, Kószó István gazdálkodó, Kószó György kisbérlő, László István állami tanító, Masa Imre gazdálkodó, Oltványi Vince gazdálkodó, Ótott Kovács József gazdálkodó, Papp János gazdálkodó, Somogyi István szabómester, Takács Mihály népiskolai igazgató, Tanács Antal gazdálkodó és Volford József gazdálkodó. Póttagok: Csóti János földműves napszámos, Huszta Imre földműves napszámos, Király Miklós kisbérlő, Kiri Antal gazdálkodó, Németh Mihály

\footnotetext{
${ }^{164}$ Vö. Erdő Péter: Plébánia és egyházközség a háború előtti Magyarországon. Magyar Egyháztörténeti Vázlatok, 9 (1997). 3-4. sz. 93-94.

${ }^{165}$ SZCSPL PHEI 1680/1944.
} 
kisbérlő, Novák Sándor MÁV nyugdíjas, Pakai István kisbérlő, Szekeres Vince gazdálkodó, Vass Vince kisbérlő és Volford Lajos gazdálkodó. ${ }^{166}$

Az egyházközségi képviselőtestület alakuló ülésen Balogh páter a háború borzalmairól beszélt, valamint a haza védelmének fontosságát hangoztatta. A honvédelmet az egyház védelmével azonosította, s a kereszténységet, a katolikus egyházat nemzetfönntartó erőnek tartotta. „Egyházunknak, hitünknek megvédése által hazánkat is megvédjük, mert a kard szerezte meg, de a kereszt tartotta fent ezer év óta ezt a hősök vérével áztatott, megszentelt földet."167

1943 augusztusában elhunyt Glattfelder Gyula érsek, püspök. Az egyházmegyét rövid ideig Raskó Sándor nagyprépost kormányozta káptalani helynökként, majd 1944 márciusában az Apostoli Szentszék Hamvas Endrét nevezte ki a csanádi egyházmegye élére. Ezért Balogh páter az alakuló ülésen megemlékezett az új főpásztorról, egyben kifejezte szándékát, hogy meghívja a plébánia létrehozásának ötvenedik évfordulójával egybekötött kenyérszentelési szertartásra: „Plébános előadja, hogy miután első ízben jöttünk össze azóta, hogy dr. Hamvas András püspök urunk vette át az ősi Szent Gellért Egyházmegye örökét, az új Főpásztort bizalommal, hűséggel és gyermeki szeretettel köszöntjük azzal az ígérettel, hogy minden rendelkezését és irányítását fiúi kötelességérzetünk tudatában fogjuk végrehajtani. Ezen évben lesz a plébánia fennállásának 50. évfordulója, melyet július hó 2-én ünnepelne meg az egyházközség a templom búcsújával és a Gazdasági Egyesület aratóünnepélyével kapcsolatosan. Ezen ünnepségre meghívja Püspök Atyánkat és felkéri az új kenyér megszentelésére is. Reméli, hogy ez alkalommal módunkban lesz hódolatunknak személyesen is kifejezést adni." 168

1945 januárjában a Miasszonyunkról Nevezett Kalocsai Szegény Iskolanővérek rendjének négy tagja költözött Szeged-Alsóközpontra, a Szent László Egészségházba. Betegápolást vállaltak, a háború miatt erre nagy szükség volt, hiszen a város kórházai mind túlterheltek, túlzsúfoltak voltak. Ám alig fél évvel később a nővérek távoztak. Erről 1945. november 9-én értesítette Hamvas Endre püspököt Vojnich Mária Aquina, a kalocsai iskolanővérek általános főnöknője. A főnökasszony írta, hogy a nővéreket november 10-15-i hatállyal elhelyezi. Az állandó megtelepedés akadályaként a megfelelő lakás és a megélhetés elemi föltételeinek hiányát jelölte meg. Ugyanakkor

\footnotetext{
166 SZCSPL PHEI 1680/1944.

167 SZCSPL PHEI 1680/1944.

168 SZCSPL PHEI 1680/1944.
} 
kijelentette, hogy a szegedi klinikai ápolónői el tudják látni azokat a föladatokat, amiket addig a nővérek végeztek.

„Folyó év január 26-án Nagyméltóságod kegyes szóbeli engedélyével a kalocsai iskolanővéreknek Szegeden tartózkodó csoportjából 4 nővér letelepedett a SzegedAlsóközponti Szent László Egészségházban, hogy ott a betegek ápolását átvegyék. Minthogy akkor a háborús körülmények között nem volt megállapítható, hogy állandó müködési terük lehet-e majd az egészségház a nővéreknek, dr. Balogh István alsótanyaközpont plébános úr és a Szerzetünk között csak ideiglenes megállapodás (Szerződés) jött létre 1945. április hó 1-én. A lefolyt 7 hónap alatt bebizonyult, hogy nővéreink szempontjából nem kívánatos az ottani állandósításuk. Bár áldozatos lélekkel vállalták a nővérek az ápolást és krisztusi szeretettel szolgálták a betegeket, rajtuk kívülálló okok mégis indokolatlanná $\mathrm{s}$ újabban már feleslegessé is tették az ottani szolgálatukat. A nővérek végleges letelepedéséhez ugyanis hiányoznak a 496. kánon által előírt feltételek: a megfelelő lakás és az állásukhoz mért megélhetés biztosítva nincs..."169

A nővérek távozásáról a csanádi főpásztor 1945. november 12-én értesítette - a plébániát Balogh távollétében vezető - Gangyi Ferencet. „A Kalocsai Iskolanővérek általános főnöknője értesített, hogy Szeged-Alsóközpontból, a Szt. László Egészségházból visszahívja a nővéreket. Jelezte azt is, hogy a betegekről a szegedi klinikai nővérek és világi ápolónők fognak gondoskodni."170

\section{6. Lemondás a szeged-alsóközponti plébániáról}

1944 októberében, a háború utolsó szakaszában Szegedre bevonultak a szovjet csapatok. Novemberben Balogh páter bekapcsolódott a politikai életbe. Szegeden részt vállalt a Magyar Nemzeti Függetlenségi Front megalakításában és a Független Kisgazdapárt újjászervezésében. Később a dálnoki Miklós Béla vezette - debreceni

\footnotetext{
${ }^{169}$ SZCSPL PHEI 2383/1945.

${ }^{170}$ SZCSPL PHEI 2383/1945.
} 
székhelyü - Ideiglenes Nemzeti Kormányban a miniszterelnöki hivatalt vezető államtitkári posztot nyerte el.

Politikai tevékenysége, illetve a Debrecenhez, majd Budapesthez kötött állami megbízása miatt nem tudta plébánosi teendőit ellátni. Ezért püspökétől szabadságot kért, aki távollétében Kováts Lajosra bízta a plébánia ellátását. Erről Kovátsot Hamvas Endre 1944. december 27-én értesítette: „Január 1-i hatállyal felmentem Tisztelendőségedet jelenleg viselt hitoktatói állásából és kinevezem s. lelkésznek a II. kápláni állásra Szeged-Alsóközpontba, de úgy, hogy ugyanott a gyakran távollévő plébános mellett a vicarius coadiutor ${ }^{171}$ tisztét is betölti a 475 . canon értelmében. Hatásköre in spiritualibus $^{172}$ teljes plébánosi, egyházközségi és plébániai javadalmi ügyekben pedig annyi, amennyit a plébános rábíz. A lelkipásztori munkabeosztást is Tisztelendőséget intézi káplántársára is kiterjedő hatállyal."173

A Kováts Lajost kinevező dokumentumot a főpap Balogh Istvánnak is megküldte, az alábbi szöveg kíséretében: „...áthelyeztem Alsóközpontba s. lelkésznek Kováts Lajos hitoktatót. Ez utóbbi Tisztelendőséged mellett a vicarius adiutor tisztét is be fogja tölteni és ezért őt külön honorárium illeti meg, amint azt a neki szóló és másolatban itt mellékelt kinevezési okmányban megírtam. A vicarius adiutori tisztség addig tart, míg Tisztelendőséged vállalt politikai missziója a plébániától gyakran elszólítja." ${ }^{\prime 174}$

Balogh páter a kinevezett helyettes plébános - adminisztrátor - ellátásáról, díjazásáról írt a püspöki hatóságnak. Úgy tervezte, hogy az édesanyjával érkező Kováts Lajos önálló háztartást vezetne, és még az ott szolgáló káplánt sem kellene ellátnia, hanem ellátás gyanánt havi 100 pengőt biztosítana neki. „Adminisztrátorunk díjazására nézve, különös figyelembe véve azt, hogy édesanyjával együtt jönne Alsóközpontra, méltóztassék megfontolás tárgyává tenni következő tiszteletteljes javaslatomat: $\mathrm{Az}$ Adminisztrátor úr saját háztartást vezetne, a segédlelkész urak ellátását 100.- pengő térítése mellett adná, én pedig kápláni jövedelmét havi 1000.- pengőre egészíteném ki.

\footnotetext{
${ }^{171}$ Vicarius coadiutor $=$ az egyházi vezetés által ideiglenes kirendelt helyettes (pl. püspöki helynök, helyettes plébános stb.)

${ }^{172}$ In spiritualibus = lelki ügyekben, a lelkiek terén.

${ }^{173}$ SZCSPL PHEI 2901/1944.

${ }^{174}$ SZCSPL PHEI 2901/1944.
} 
A kezdet nehézségein természetesen szeretetből is átsegíteném bizonyos naturáliák ${ }^{175}$ átengedésével."176

A javaslatra Hamvas püspök december 29-én reagált. Kifejtette, az önálló adminisztrátori háztartás gondolata mögött az húzódik meg, hogy Balogh más településen akar berendezkedni, mégpedig hosszútávra. Ehhez azonban a lelkésznek szabadságot kell kérni. Szabadságot a püspök mindössze három-négy hónapra adhat, és az Apostoli Szentszék is legföljebb egy évre.

„December 27-én kelt levelében ajánlja, hogy az általam Tisztelendőséged mellé kinevezett vicarius adiutor külön háztartást vezessen, minek fedezetére a szükséges költséget Tisztelendőséged neki megtéríti. Ebből azt következtetem, hogy Tisztelendőséged saját háztartását feloszlatni, illetve a politikai állásának megfelelő székhelyre tartósan átvinni kívánja. Ez esetben azonban a plébániától való állandó távollétről van szó, melyhez én engedélyt nem adhatok hosszabb időre, mint háromnégy hónapra, és amelyhez az Apostoli Szentszék is egy félévre, vagy legföljebb fontos okból egy évre szokott engedélyt adni. Amennyiben tehát ily szándéka van Tisztelendőségednek, akkor szabadságot kérjen tőlem, és én azt a nekem az egyházjogban megadott keretek között megadom."177

Balogh azonban - miközben az országos politikai élet egyik legmeghatározóbb és legaktívabb szereplője lett - nem törődött papi szolgálatával. Sem plébánosi teendőit nem látta el, sem püspökétől nem kért engedélyt a távolmaradásra. Ezt Hamvas Endre sérelmezte, de kompromisszumra hajló módon - bízva benne, hogy Balogh a katolikus egyház érdekeit is képviseli a kormányban - nem tette szóvá. Csak már az általa engedélyezhető szabadság letelte után értesítette a politikus plébánost. 1945. április 21én írt levelében így fogalmazott:

„Tisztelendőségedet 2901/944. sz[ám]. a[latt]. felhívtam, hogy szabadságot kérjen, ez azonban még nem történt meg. Mivel az általam engedélyezhető szabadságidő azóta már kitelt, megsürgetem az ügyet. Értesítem arról is, hogy a vicarius adiutor nincsen megelégedve helyzetével, A plébánián a háztartásbeliek úgy tekintik, mintha megtürt egyén volna, a külön háztartás vezetése pedig számára nehéz, sőt szinte lehetetlen külön konyha hiányában. Ezen az állapoton okvetlenül segíteni kell."178

\footnotetext{
${ }^{175}$ Naturália = termény, természetbeni járandóság.

${ }^{176}$ SZCSPL PHEI 2901/1944.

177 SZCSPL PHEI 2901/1944.

178 SZCSPL PHEI 2901/1944.
} 
Kováts Lajos nem volt megelégedve helyzetével. Legjobban az zavarta, hogy sem a házvezetőnő, sem a káplán nem tekinti őt felettesének. Sőt, úgy bánnak vele, mintha csak megtürt személy lenne. Édesanyjának csak hosszas unszolás után adtak külön szobát, és neki csak egy helyiség áll rendelkezésre. Ugyanakkor - jelentette a püspöki hivatalnak - Balogh páternek három szoba fönn van tartva, amit senki sem használ, és a plébánián többen is laknak: a háztartási alkalmazottakon kívül a nyugdíjas sekrestyés és az egyik helyi rendőr - családostól. Így az állandó hangoskodás zavarja lelkészi hivatal ügyintését. Kováts szerint a ház lakói mind Balogh István „,bizalmi emberei" és az ő ellenségei. ${ }^{179}$

Balogh páter a püspöknek írt válaszlevelében kifejtette, hogy az adminisztrátor alkalmazása neki csak kiadásokkal, többletterhekkel jár, és csupán azért hajlandó belemenni ebbe a helyzetbe, mert morális kötelességének tekinti a híveiről való lelkipásztori gondoskodást. Tételesen cáfolta Kováts Lajos kifogásait, és védelmébe vette a ház lakóit is, akiket értékes és az egyháznak sok szolgálatot tevő embereknek állított be. „2901/1944. sz. alatt folyó hó 2-án kelt fölhívására tisztelettel kérem, hogy szabadságomat meghosszabbítani méltóztassék. Ami a vikárius adjutor helyzetét illeti, tudom, hogy nincs megelégedve, de ez kizárólag az ő betegségéből származó dispozíció $^{180}$. Jövedelmét április hóban 1500 P-re, május hónapra 2000 P[engő]-re egészítettem ki a magaméból. Tehát anyagilag véve tényleges ráfizetés a számomra a mai helyzet, melyet kizárólag erkölcsi okokból látszik szükségesnek fenntartani. Tudtommal külön háztartást vezet, miután a plébánia konyháját kizárólag ő használja. Az eddigi két lakószobán felül a harmadikat is felajánlottam, de azt szükségtelennek mondotta." 181

Hamvas püspök 1945. június 16-án írt Balogh szabadságolása ügyében Grősz József kalocsai érseknek, aki - kinevezett pápai nuncius hiányában és az esztergomi érseki szék betöltetlensége miatt - az Apostoli Szentszék magyarországi képviselője volt. „Dr. Balogh István szegedalsóközponti plébánosnak államtitkárrá történt kineveztetése alakalmával 1944. december 29-én három hónapi szabadságot adtam és felhívtam figyelmét, hogy ezen túlmenőleg csak az Apostoli Szentszék, jelenleg annak magyarországi képviselője, Nagyméltóságod adhat szabadságot." 182

\footnotetext{
${ }^{179}$ SZCSPL PHEI 224/1945.

${ }^{180}$ Diszpozíció $=$ helyzet, kedv, hangulat.

${ }^{181}$ SZCSPL PHEI 2901/1944.

182 SZCSPL PHEI 1101/1945.
} 
Grősz József 1945. június 25-én 1029/1945. számú rendeletével szabadságot engedélyezett Baloghnak 1945. december 31-i határidővel. Erről Hamvas Endre július 5-én értesítette az államtitkárt. „Tisztelendőségednek június 7-én kelt kérelmét felterjesztettem Grősz József kalocsai érsek úrhoz, mint aki az Apostoli Szentszék magyarországi megbízottja. Az ő meghatalmazása alapján december 31-ig terjedő szabadságot engedélyezek. Többre ö nekem felhatalmazást nem adhatott, mert az Apostoli Szentszék sem szokott beneficiátusoknak ${ }^{183}$ egy évnél tovább terjedő szabadságot adni.",184

Ezt a páter július 12-én kelt levelében nyugtázta, egyben kifejezte köszönetét. Hamvas püspöknek címzett leveléből: „2901/1944. sz. folyó hó 5-én kelt leiratát köszönettel vettem. Tudomásul vettem azt is, hogy szabadságom ez év végéig, december 31-ig terjed. Nagy örömmel köszöntöm a Főtisztelendő Egyházmegyei Hatóságnak azon szándékát, hogy mindkét segédlelkészi állást is betölteni méltóztatik. Híveim, kikkel kapcsolatom távollétem dacára is nagyon élénk, igényei állandóan nőnek és bizony azok kielégítése nagyon kívánatos." 185

1945 utolsó napján Balogh szabadsága lejárt. 1946. január 2-án a püspök levélben kérte, hogy vagy - amint azt a kánonjogi elöírások megkövetelik - térjen vissza plébániájára, vagy mondjon le javadalmáról. Folyó ügyei elintézésére a főpap két hetet adott. Mivel Balogh nem jelzett vissza, Hamvas Endre február 13-án a következő döntést hozta: „...a 2169. canon értelmében a szeged-alsóközponti plébániát ezennel megürültnek nyilvánítom."186

Balogh István kész helyzetben találta magát. Mivel a kánonjog által elöírt plébánosi kötelességeit - állandó távolléte és elfoglaltsága miatt - nem tudta ellátni, püspöke megfosztotta lelkészi állásától és jövedelmétöl. ${ }^{187}$

Erre Balogh 1946. március 6-án reagált - mégpedig elég különösen: lemondott plébánosi állásáról, amit - a püspök föntebb idézett rendelete értelmében - már nem is birtokolt. Kifejezte, hogy a csanádi egyházmegyével - politikusként is - jó kapcsolatban akar maradni. „Kézhez vettem az értesítést, mely szerint az érvényben lévő canonok

\footnotetext{
${ }^{183}$ Beneficiátus = egyházi javadalmas.

${ }^{184}$ SZCSPL PHEI 1101/1945.

${ }^{185}$ SZCSPL PHEI 1101/1945.

${ }^{186}$ SZCSPL PHEI 1101/1945.

${ }^{187}$ Az alsóközponti plébánia és a kegyúr város kapcsolatáról részletesen: Kisházi-Kovács László, 2001. 73-81.
} 
értelmében szabadságom meg nem hosszabbítható és folytatólagos távollétem miatt a Szeged-alsóközponti plébánia megürültnek tekintendő. A canonok rendelkezéseit illő tisztelettel tudomásul veszem és híveim iránt érzett szeretetem miatt sajnálattal bár és kizárólag más, ugyancsak fontos szolgálati érdekből plébániámról ezennel lemondok. Öszintén kívánom, hogy az a bensőséges viszony, amelyben eddig a csanádi egyházmegyével voltam, s amely Istenben boldogult Gyula püspök emléke miatt is elszakíthatatlan marad, s azt a magam részéről hüségesen ápolni fogom."

Balogh István 1945-ös politikai szereplése, pontosabban annak a csanádi egyházmegyéhez kapcsolódó eseményei is említést érdemelnek, bár kronológiailag megelőzik a plébánosi állásról való lemond(at)ását. Érdekes egy 1945. július 12-én Hamvas Endrének írt levél, amelyben Balogh páter saját politikai életben elfoglalt helyét, illetve külső megítélését értékelte. A sorok reális helyzetértékelésről és pontos problémaérzékelésröl tesznek tanúbizonyságot. Balogh pátert egyik politikai erő sem ítélte meg egyértelmüen. Hol „szalonkommunistának”, hol meg „vörös papnak” gúnyolták. Ráadásul a - számos irányzatot magába fogadó - kisgazdapárton belül sem volt stabil a helyzete sokszor érték támadások. Erről így írt:

„Az egyik oldalról reakciósnak minősítenek, ugyanakkor a másik oldalon »Szalonkommunistának« tisztelnek, meg »vörös papnak«. Nem mintha ez újdonság volna, mert így volt ez már az indulás pillanatában, decemberben is, sőt már novemberben. Csak azóta nemcsak a távlatok változtak, de az oldalak is. Ök azt mondják, én változtam, én az ellenkezőjét állítom és magamban azt hiszem, hogy most sem akarok mást, mint akkor: őszinte és minden terrortól mentes demokráciát és abban egyházamnak azt a helyet és szabadságot, mely minden körülmények között megilleti." 189

$\mathrm{Az}$ 1945. novemberi országgyülési választásokon Balogh páter a győztes Független Kisgazdapárt listáján indult - és jutott mandátumhoz. A fönnálló törvények értelmében minden képviselőjelölt katolikus papnak engedélyt kellett kérnie az induláshoz attól a helyi ordináriustól, akinek egyházmegyéjéhez a választókerületet tartozik. Balogh 1945. október 18-án a csanádi püspöktől, valamint Mindszenty József hercegprímás, esztergomi érsektől kért engedélyt. (Az előbbitől meg is kapta.) „Hivatkozással a fennálló rendelkezésekre kérem, hogy a képviselői mandátum

\footnotetext{
188 SZCSPL PHEI 1101/1945.

${ }^{189}$ SZCSPL PHEI 1333/1945.
} 
vállalásához szükséges engedélyt megadni, illetőleg a Hercegprímás Úrtól is megszerezni szíveskedjék."

$\mathrm{Az}$ 1945. november 4-én tartott nemzetgyülési választásokon - az országos arányoknak megfelelően - a tízes számú választókerületben (Csongrád-Csanád megye) is a kisgazdapárt szerezte meg a legtöbb képviselői helyet. Mivel a listát - amelyről tizenkét képviselő jutott a parlamentbe - Balogh István vezette, mandátumhoz jutott. A választás másnapján Hamvas püspök 2221/1945. számmal levelet intézett hozzá az alábbi szöveggel: „Felterjesztettem kérését, hogy képviselőséget vállalhasson, a hercegprímás úrnak, aki azt válaszolta, hogy »az engedély meg nem adható«. Ennek értelmében kérem, hogy a képviselőségről lemondjon és lehetőleg foglalja el plébániáját." ${ }^{, 191}$

1945. november 9-én kelt válaszában Balogh kifejtette, hogy a törvény azt írja elő, hogy a helyileg illetékes föpap engedélye szükséges. Mivel pedig ő a csongrádi listáról jutott mandátumhoz, csak a csanádi püspök engedélye volt szükséges, amit meg is kapott. Így aztán Mindszenty - minden jogalapot nélkülöző - fölszólítását nem fogadja el és képviselői helyéről nem mond le. „A Hercegprímás Úr engedélyére tehát, a fennálló jogszabályok értelmében, nekem szükségem nincs. Lehetséges, hogy a Hercegprímás Úr megítélése alapján az egyháznak nincs szüksége arra, hogy képviselői tevékenységet fejtsek ki, a püspöki kar túlnyomó többségének azonban homlokegyenest ellenkező az álláspontja. Meg vagyok győződve róla, ha a Hercegprímás Úr egyszer abban a helyzetben lesz, hogy tárgyilagosan bírálja, nem csak mindazt, amit itteni tevékenységem mint pozitív eredményt ért el, de azt is, amit mindezidáig elhárítanom sikerült, más álláspontra fog helyezkedni."

\footnotetext{
${ }^{190}$ SZCSPL PHEI 2221/1945.

${ }^{191}$ SZCSPL PHEI 2221/1945.

${ }^{192}$ SZCSPL PHEI 2221/1945.
} 


\section{AZ ÁLLAMTITKÁR}

\section{1. A sajtóügyek felelőse ${ }^{193}$}

Balogh István, az Ideiglenes Nemzeti Kormány miniszterelnöki hivatalának kisgazdapárti államtitkáraként 1944 decembere és 1945 nyara között a sajtóügyekért és a papírgazdálkodásért is felelős volt. Ebben a fejezetben az államtitkársága idején keletkezett miniszterelnökségi iratok ${ }^{194}$ és néhány korabeli sajtótermék alapján tekintjük át Balogh páternek a sajtópolitika alakításában 1944-1945-ben betöltött szerepét. ${ }^{195}$

Miklós Béla, az Ideiglenes Nemzeti Kormány elnöke 1945. január 19-én kérte Ivan Zaharovics Szuszajkov szovjet vezérezredestől ,az ország felszabadított részein a nyomdai üzemek müködésének engedélyezését”, mivel a kormánynak, az állami hivataloknak és az önkormányzatoknak nyomtatványokra volt szüksége. ${ }^{196}$

A kormányfő 1945. január 23-i Szuszajkovhoz írt levelében - mivel a három nappal korábban megkötött fegyverszüneti egyezmény életbe lépett - pedig arra kérte a megszálló Vörös Hadsereg vezérezredesét, adja ki „az összes napilapok részére a megjelenési engedélyt". ${ }^{197}$

Az Ideiglenes Nemzeti Kormány debreceni székhelyű időszakában a Magyar Kommunista Párt Néplap, a Független Kisgazdapárt Debrecen, a Szociáldemokrata Párt Népszava címmel jelentetett meg sajtóterméket. Jellemző, hogy a miniszterelnök levelében közölte: a kommunista Néplap már müködik, a többi megjelenéséhez pedig

${ }^{193}$ Ez az egység egy korábban megjelent tanulmányom bővített és kiegészített változata. Miklós Péter Balogh István és a sajtóügyek (1944-1945). Belvedere Meridionale, 21 (2009). 3-4. sz. 53-60.

${ }^{194}$ Magyar Országos Levéltár. Miniszterelnökség iratai. Általános iratok. 1944-1945. (a továbbiakban: MOL XIX-A-1-j)

195 Vö. Z. Karvalics László: A malacvilágosság ideje... Félszázéves sajtótanulságok nyomában. A sajtószabadság korlátai. 1944-1948 In: A hír értékei. Szerk. Csermely Ákos, Sükösd Mihály. Budapest, 2001. 105-118.

${ }^{196}$ MOL XIX-A-1-j-75-V-1945

${ }^{197}$ MOL XIX-A-1-j-89-V-1945 
már minden föltétel adott, s ezért ,,a kormány úgy a maga, mint az összes politikai pártok nevében kéri a Vezérezredes Urat a fenti lapok megjelenési engedélyét sürgősen kiadni". 198

Miklós Béla miniszterelnök 1945. január 29-én Debrecenben a Magyar Kommunista Párt országos titkárságának írt levelében arra figyelmeztette a kommunista párt vezetőit, hogy a papírkészlet a kormány, nem pedig a szovjet katonai támogatását élvező Magyar Kommunista Párt rendelkezése alatt áll. „Folyó hó 26-án Nemes József sajtófönököt Budapestre indítottam azon megbízással, hogy ott a Polgármester úrral közölje, hogy a kormány a Budapesten található összes papírkészletet lefoglalja és az azzal való rendelkezési jogot kizárólag magának tartja fenn. Ezzel szemben a Budapesten megjelenő Szabadság címü lap folyó hó február 28-án a Kommunista Párt részéről egy felhívást közölt, mely szerint a Budapest területén lévő raktárakban, üzletekben és magánosoknál található mindennemü papírkészletet, tehát a rotációst is a Kommunista Pártnak kell bejelenteni. Értesítem a Párt Titkárságot, hogy a fent kiadott kormányrendelet értelmében úgy Budapesten, mint vidéken található összes papírmennyiség a kormány kizárólagos rendelkezési joga alá tartozik."

1944 decemberétől, az Ideiglenes Nemzeti Kormány megalakulásától kezdve a miniszterelnökség politikai államtitkáraként Balogh István intézte a sajtóorgánumok megjelenésének engedélyezését és hatáskörébe tartozott a papírellátás kérdése is. A koalíciós pártok (elsősorban központi, országos) sajtótermékei természetesen előnyösebb elbírálásban részesültek és hamarabb kaptak engedélyt.

Balogh 1945. február 23-án írt levelében engedélyezte a megjelenést a Nemzeti Parasztpárt lapja, a Szabad Szó számára. „Megengedem, hogy »Szabad Szó« címmel Budapesten megjelenő lapot adjon ki, az utcai terjesztés jogával, hétköznap 4 oldal, vasárnap 8 oldal terjedelemben. A példányszámot később fogom meghatározni. A lap kiadója a »Sarló« Lapkiadó Kft."200

A Demokratikus Ifjúsági Szövetség országos titkára, Kiss József arra kért engedélyt hogy Szabad Ifjúság címmel lapot jelentethessen meg szervezete. Az államtitkár 1945. február 20-án hozzájárult az újság havi hét alkalommal, négy oldal

\footnotetext{
${ }^{198}$ MOL XIX-A-1-j-89-V-1945

${ }^{199}$ MOL XIX-A-1-j-89-V-1945

${ }^{200}$ MOL XIX-A-1-j-370-V-1945
} 
terjedelemben (Debrecenben) történő megjelenéséhez. ${ }^{201}$ Győry Lászlónak, a Debreceni Színpad címü képes hetilap szerkesztőjének papírkérését azonban 1945 februárjában a papírhiány miatt „egyelöre nem teljesíthetőnek” minősítette. ${ }^{202}$

Ugyancsak 1945. február 20-án Rézmüves Jenő kért engedélyt a Nyírbátor címü lap kiadására, amely szándékai szerint, mint fogalmazott, „mind az 5 párt érdekeit szolgálja” „Alulírott Rézműves Jenő, nyírbátori lakos a nyírbátori járási Rendőrkapitányság politikai osztályának vezetője és a Magyar Kommunista Párt nyírbátori szervezetének titkára tiszte lettel kérem engedélyezni a Nyírbátorban lévő üzemen kívüli nyomda üzembe helyezését [...] A pártközi érdekek szem előtt tartásáért személyemben vállalok felelősséget. A nyomdát az orosz parancsnokság fogja rendelkezésre bocsájtani, a kinyomtatást a helyi nyomda végzi el."203 Az engedélyt Balogh még aznap megadta, az újság felelős szerkesztője Rézműves Jenő és dr. Molnár László lett.

1945. március 21-én a kiskunhalasi polgármesteri hivatalban találkozó volt, amelyen a résztvevők (Fazekas István, a kommunista párt helyi szervezetének titkára, dr. Kovács Tibor polgármester, Ságodi Győző, a Halasi Hirek szerkesztője és Gaál Margit jegyzőkönyvvezető) a ,„Halasi Hírek« címü időszaki politikai lapjuk részére további megjelenési engedélyt kértek". ${ }^{204}$

Arra hivatkozva, hogy a szovjet városparancsnok-helyettes örnagy utasította a polgármestert hogy az Ideiglenes Nemzeti Kormány által március 13-án betiltott lap továbbra is megje lenhet, mert ő „mint a lap cenzora annak tartalmával teljes mértékben meg van elégedve". ${ }^{205} \mathrm{Az}$ erről készült jegyzőkönyvet a polgármester április 5-én megküldte Pest-Pilis-Solt-Kiskun vármegye alispánjának, aki helyett a főszolgabíró április 16-án továbbította azt a miniszterelnöki hivatalnak. ${ }^{206}$

Balogh államtitkár április 25-én írt levelet az alispánnak, amelyben a következőképp fogalmazott: „A »Halasi Hírek« címü időszaki lap betiltása tárgyában folyó évi március 13-án kiállított rendeletemet fenntartom. Alispán urat személyében felelőssé teszem a lap-megjelenés beszüntetéséért és lezárandó azonnal a nyomda is. A

\footnotetext{
${ }^{201}$ MOL XIX-A-1-j-319-V-1945

${ }^{202}$ MOL XIX-A-1-j-886-V-1945

${ }^{203}$ MOL XIX-A-1-j-362-V-1945

${ }^{204}$ MOL XIX-A-1-j-1212-V-1945

${ }^{205}$ MOL XIX-A-1-j-1212-V-1945 1.

${ }^{206}$ MOL XIX-A-1-j-1212-V-1945 2-3.
} 
lapengedélyek kiadása tárgyában kizárólag az Ellenőrző Bizottság és a Miniszterelnökség jogosultak intézkedni." ${ }^{207}$ Kiskunhalas két, a két világháború között müködő nyomdája közül a Malom utca 6. szám alatt találhatót a kommunista párt 1945. március 23-án birtokba vette és lezárta. A Halasi Híreket akkoriban a Práger János tulajdonában lévő Molnár utca 2. szám alatti nyomda állította elő. ${ }^{208}$

Az újságot - amely aztán 1946 decemberétől Hirek címmel jelent meg szerkesztőbizottság állította össze, amelynek tagjai Fazekas István, a kommunista párt helyi titkára, Bundzsák István, a Szociáldemokrata Párt kiskunhalasi elnöke és Csontos Jenő, a Nemzeti Parasztpárt ottani titkára voltak. ${ }^{209}$ (Az, hogy mi állhatott az egyébként kommunista és szovjetbarát lap betiltásának hátterében, további kutatást igényel.)

Egy másik példa Pest-Pilis-Solt-Kiskun vármegyéből: a kisgazdapárti Homoki József, a Kecskeméti Lapok felelős szerkesztője 1945. október 12-én írt papírigénylő levelet a miniszterelnöki hivatalnak, amelyben rotációs papír kiutalását kérte. „A Kecskeméti Lapok szerkesztősége tisztelettel kéri $20000 \mathrm{~kg}$ 12-es rotációs papír kiutalását. A lap hetenkint kétszer jelenik meg 12000 példányban. A Kecskeméti Lapok a demokratikus pártok szolgálatában áll, szerkesztésében részt vesznek a munkáspártok és Független Kisgazdapárt. A felszabadulás óta a mai napig a Kecskeméti Lapok maga gondoskodott papírszükségletéről, sőt az év első felében más lapokon is segített, ma azonban nem tud papírhoz jutni és már a legközelebbi szám megjelenése sincs biztosítva papírhiány miatt. A lap szünetelése a választásokat megelőző hetekben katasztrofális lenne." 210

Olyan is előfordult 1945 őszén, hogy a Kecskeméti Nemzeti Bizottság saját orgánuma, a Kecskeméti Lapok számára a kommunista párt helyi titkárságától volt kénytelen papírt kérni. ${ }^{211}$ 1945. október 23-án Homoki József viszont már arról tájékoztatta a Balogh István államtitkár vezette miniszterelnöki hivatal papírellátásért

\footnotetext{
${ }^{207}$ MOL XIX-A-1-j-1212-V-1945 4.

208 Országos Széchényi Könyvtár Irattára 56/1947. Vö. Bánfi Szilvia: Tragikus nyomdász sorsok, megsemmisült nyomdák. Magyar Könyvszemle, 121 (2005). 4. sz. 449-463.

${ }^{209}$ Horváth Etelka - Modok Balázs: A kiskunhalasi nyomdászat, sajtó és könyvkiadás történetéröl. In: Kiskunhalas története. 3. kötet. Szerkesztette Ö. Kovács József, Szakál Aurél. Kiskunhalas, 2005. 419420 .

210 Bács-Kiskun Megyei Önkormányzat Levéltára (a továbbiakban: BKMÖL) Az Első Kecskeméti Hírlapkiadó és Nyomda Rt. iratai XI. 7. 1. doboz 11. tétel

${ }^{211}$ BKMÖL A Kecskeméti Nemzeti Bizottság iratai. XVII. 46. 19. doboz 657/1945.
} 
felelős megbízottját, Pál Gyula miniszteri biztost, hogy „,a Kecskeméti Lapok hetenként kétszer jelenik meg. 10000 példányban".212

Balassa Sándor debreceni újságíró 1945. április 11-én adott be kérelmet a Debreceni Hírlap címü lap megjelentetésének engedélyezésére. Kérelmező levelét a miniszterelnöknek és Balogh Istvánnak is eljuttatta, amelyekhez mellékelte Juhász Nagy Sándor támogató és közbenjáró levelét is. Balogh páternek címzett levelében a következőket írta: „A Debreceni Hírlap megjelenése ügyében beadott második kérvényemre eddig semmiféle választ nem kaptam, pedig Főtisztelendőséged debreceni tartózkodása alatt volt olyan kedves azt az ígéretet tenni, hogy a lapengedélyt megkapom. [ ...] Hét éve vagyok állás és kenyér nélkül a sors által rám mért csapás folytán három árva unokámmal szaporodott meg, akiknek kenyeret kell adnom, tehát úgy vélem, hogy igazságos kívánságom teljesítését joggal remélhetem. Kérem Államtitkár Urat, hogy vegye jóakaratába kérésemet."213

Balassa Sándor 1906 óta dolgozott újságíróként Debrecenben. Előbb a Szabadság, a Debreceni Újság, majd a Debrecen címü lapok munkatársa volt. Később a Debreceni Hírlap szerkesztője és laptulajdonosa lett. A négy évtizedes hírlapírói tevékenyég eredményeként jó kapcsolatot alakíthatott ki a város politikai életének szereplőivel. Így érte el Juhász Nagy Sándornál - az 1919-es Berinkey-kormány egykori igazságügyminisztere, aki abban az időben az Ideiglenes Nemzetgyülés egyik alelnöke volt -, hogy interveniáljon érdekében a kormányfőnél. A Debreceni Hírlap végül nem kapta meg a müködési engedélyt.

Balogh a Polgári Demokrata Párt elnökségének 1945. április 19-én írt, amelyben engedélyezte számukra a Világ című lap kiadását. „Megengedem, hogy »Világ« címen politikai napilapot jelentessen meg 4 oldal terjedelemben, az utcai árusítás jogával. A lappéldányok számát később fogom megállapítani. Tudomásul veszem, hogy a lap felelős szerkesztője Supka Géza." ${ }^{214}$ A levélre kézírással rá van írva, hogy „Kultuszminiszter úrnak á[1lam]. t[itkár]. adta át.”215 Úgy látszik, Balogh páter igyekezett szívélyes kapcsolatot ápolni a koalíciós pártokkal. A Világ ugyanis a Polgári Demokrata Párt lapjaként jelent meg, amelynek elnöke 1945 áprilisa és júliusa között gróf Teleki Géza, az Ideiglenes Nemzeti Kormány vallás- és közoktatásügyi minisztere

\footnotetext{
${ }^{212}$ BKMÖL XI. 7. 1. doboz 11. tétel

${ }^{213}$ MOL XIX-A-1-j-2129-V-1945

${ }^{214}$ MOL XIX-A-1-j-1019-V-1945

${ }^{215}$ MOL XIX-A-1-j-1019-V-1945
} 
volt. Balogh István 1945. április 19-én a Szakszervezeti Közlönynek és a Népsportnak adott lapengedélyt. $^{216}$

A szovjet dominanciájú Szövetséges Ellenőrző Bizottság nyomására 1945 áprilisától a lapkiadási engedélyek utolsó bekezdése a következő mondat volt: „Ezen engedélyem csak az Ellenőrző Bizottság hozzájárulása után érvényesíthető.” 1945. április 21-én a Képes Világ (a Nemzeti Parasztpárt tizenkét oldalas képes hetilapja) ${ }^{217}$, április 28-án a Reggeli Újság (a Polgári Demokrata Párt nyolcoldalas hetente kiadott ideológiai lapja) ${ }^{218}$, április 29-én $A$ kereskedö és a Váci Napló kapott engedélyt a megjelenésre. ${ }^{219}$ 1945. június 25-én a Magyar Alföld (a Magyar Nemzeti Függetlenségi Front szentesi újságja) nyert lapengedélyt Balogh Istvántól. ${ }^{220}$

Csuka János délvidéki származású író, újságíró, szociológiai kutató akivel Balogh István már a második világháború előtt szakmai kapcsolatba került levélben fordult az államtitkárhoz 1945. április 8-án. Csuka levelét a Független Kisgazdapárt országos központjába címezte, $\mathrm{s}$ kifejezte reményét, hogy „Államtitkár úr bizonyára emlékszik még írásaimra a Délmagyarországban és találkozásunkra is a lap szerkesztőségében".221

$\mathrm{Az}$ újságíró emlékeztetett: már korábban is fölmerült közöttük az együttműködés lehetősége, amikor még Balogh a Délmagyarország tulajdonosa volt. Akkor azonban inkább Budapestre ment dolgozni. Csuka János levelében állásért folyamodott Balogh páterhez. Mint írta: „,...a bombázáskor combtörtést szenvedtem. Most kezdtem kilábalni a sérülésből s egyben jelentkezem is felajánlva szolgálataimat. Készséggel és örömmel folytatnám azt a munkát, amit a Délmagyarországban annyi kedvvel végeztem. Talán, mint a délszláv ügyek ismerője valamelyik minisztériumban, mint kisebbségi előadó hasznos munkát végezhetnék? Vagy Államtitkár Úr lapjának is eredményesen dolgozhatnék. Egyszóval nem nagyon válogatok, ha kedvenc munkakörömröl: a délszláv viszony ápolásáról van szó."222

\footnotetext{
${ }^{216}$ MOL XIX-A-1-j-1031-V-1945 és MOL XIX-A-1-j-1032-V-1945

${ }^{217}$ MOL XIX-A-1-j-1031-V-1945

${ }^{218}$ MOL XIX-A-1-j-1392-V-1945

${ }^{219}$ MOL XIX-A-1-j-1432-V-1945 és MOL XIX-A-1-j-1434-V-1945

${ }^{220}$ MOL XIX-A-1-j-1450-V-1945

${ }^{221}$ MOL XIX-A-1-j-934-V-1945

${ }^{222}$ MOL XIX-A-1-j-934-V-1945 2.
} 
1945. április 23-án Balogh „a miniszterelnök helyett” Csuka Jánost a miniszterelnöki hivatalba a sajtóügyekért felelős előadóvá nevezte ki kétezer pengős fizetéssel. Akkoriban a miniszterelnökségen három sajtófelelős dolgozott: Csuka Jánoson kívül dr. Vidor Gyula (aki ötezer-ötszáz pengőt keresett) é s Hegedűs Nándor (akinek háromezer pengő volt a fizetése). ${ }^{223} \mathrm{~A}$ rohamos infláció miatt Balogh páter Csuka fizetését 1945. július 10-én április 1-jei hatállyal háromezer pengőre emelte. ${ }^{24}$ 1945 novemberében - amikor az Ideiglenes Nemzeti Kormány megbízatása megszünt a kormányfő mellett müködő hivatalnak négy sajtómunkatársa volt: Csuka János, Geleji Dezső, Hegedűs Nándor és Molnár Jenő. ${ }^{225}$

Balogh Istvánnak már a sajtóélet újbóli megindulásának idején is több lapja volt, hiszen tulajdonosa volt a Magyar Nemzet és A Mai Nap címü orgánumoknak. 1945. április 26-án levelet írt Hegedűs Gyulának, aki akkoriban mindkét lapnál a főszerkesztői posztot töltötte be. Ebben a következőket fogalmazta meg: „Felkérem, szíveskedjék gondoskodni arról, hogy úgy a Mai Napnak, mint a Magyar Nemzetnek üzletvitelét egymástól elkülönítsék. Mindkét lap külön könyveléssel bírjon, mint két külön vállalat.",226

Barankovics István 1945. április 25-én írt levelet Miklós Béla miniszterelnöknek, amelyben jelezte: tudomása van arról, hogy a kormány lapengedélyt szeretne a Magyar Nemzetnek, s ezért soraival tisztázni akarja, hogy az újság nevének tulajdonosa a kiadó cég, amelynek ő az egyik tulajdonosa és képviselője. Egyúttal fölsorolta a lap szerkesztőinek és munkatársainak az 1940-es évek elején kifejtett demokratikus és náciellenes tevékenységét, amely aztán a német megszállás utáni betiltáshoz vezetett.

„Régebben a magyar olvasóközönség - írta Barankovics - a németbarát és fasiszta külpolitika legkiemelkedőbb sajtóellenfelét egy Magyar Nemzet címü lapban látta, amelynek a német megszállást megelőző esztendőben, egészen 1943. március 19ig én voltam a felelős szerkesztője, felelős kiadója és egyik publicistája. Ebben a minőségemben a lap politikai irányítása is az én kezemben volt, $\mathrm{s}$ a lapot kiadó »Magyar Nemzet Lapkiadó Kft.«-t mint egyik cégjegyző, én jegyeztem.

\footnotetext{
${ }^{223}$ MOL XIX-A-1-j-934-V-1945 19.

${ }^{224}$ MOL XIX-A-1-j-934-V-1945 23.

225 MOL XIX-A-1-j-934-V-1945 32-34.

${ }^{226}$ MOL XIX-A-1-j-3860-V-1945
} 
A magyar publicisztika egy legkiválóbb mesterének, Pethő Sándornak tragikus halála után - kevés megszakítással - Szekfü Gyula úr volt a lap publicisztikai gárdájának szellemi vezére. Szekfü Gyula tekintélye és az én politikai irányításom fogta össze az akkori demokratikus publicisztikai és író gárdának jelentős részét, mint a lap belső és küldő munkatársait.

A demokráciáért folyó küzdelem idején a Magyar Nemzet olyan szerepet töltött be, amelynek jelentőségét majd a történelem méri le. A közvélemény szemében ma is kétségtelen, hogy a magyar demokráciáért és a németbarát külpolitika elleni harcban semmiféle szellemi közösség sem állt helyt különb módon."227

Mivel azonban az előbbiekben idézett levelére Barankovics nem kapott választ, 1945. május 3-án ismét - immár ingerültebb hangnemben - írt a kormányfőnek. Barankovics István áttekintette az újonnan kialakult sajtóhelyzetet, vitatta Hegedüs Gyula - aki a Magyar Nemzetet akkoriban szerkesztette - jogosultságát a lap irányítására, végül jogigényét jelentette be.

„Nem lehet tehát elzárkóznom az elöl a vélemény elöl, hogy a Magyar Nemzet nevének megkérdezésem, beleegyezésem és kártalanításom nélkül történt felhasználása a kielégítő jogi alapot nélkülözi, ezért ez ellen a leghatározottabban tiltakozom és az ebből származó esetleges jogigényemet fenntartom. Állítom azonban azt is, hogy az igazságosság íratlan, de a demokráciában nyomatékosan kötelező elemi követelményeivel sem egyeztethető össze a Magyar Nemzet nevének megkérdezésem, beleegyezésem és kártalanításom nélkül történt felhasználása."228

Levelének végén Barankovics - nyilván Balogh páterre célozva - a következőket írta: „Miniszterelnök Úr, én nem gasztronómiai áldozatokat mutattam be a demokrácia istennőjének, és nem tartozom azok közé sem, akik inkább az eszméből, mint az eszméért élnek és éltek." ${ }^{229}$ Barankovics leveleire végül Bojta Béla miniszterelnökségi osztálytanácsos - Balogh bizalmasa - válaszolt szükszavúan, vitatva Barankovics István jogát a lap nevéhez.

A Magyar Nemzet egészen az 1950-es államosításig Balogh István érdekeltségi körébe tartozott, 1945 végéig a kormány félhivatalos lapjaként jelent meg, Barankovics semmilyen kártérítést nem kapott.

\footnotetext{
${ }^{227}$ MOL XIX-A-j-1765-1945 1.

${ }^{228}$ MOL XIX-A-j-1765-1945 5.

${ }^{229}$ MOL XIX-A-j-1765-1945 7.
} 
1945. július 18-án a Nemzeti Parasztpárt országos napilapja, a Szabad Szó kiadása papírhiány miatt bizonytalanná vált (s végül két napig az újság nem is jelent meg). A szociáldemokrata Népszava a sajtószabadság elleni támadásként értékelte, hogy a kormányhivatal nem utalt ki elegendő papírt a parasztpárti lap számára. „Ugyanakkor - írta a Népszava - naponta két lap jelenik meg, melynek semmi, de semmi köze egyik demokratikus párthoz sem. E két lap: »Magyar Nemzet« és »A mai nap«. Tudja meg az ország közvéleménye, tudják meg a munkások, az elvtársak, hogy a »Magyar Nemzet« és »A mai nap« nyomdájában, a Hungáriában garmadával tornyosodik a rotációs papír.” Noha az idézett cikkben nem szerepelt a neve, köztudomású volt, hogy az említett két lap Balogh páter tulajdonában van. ${ }^{230}$

Két nappal később a Népszava cikkírója már név szerint támadta Balogh Istvánt, akinek szegedi lapszerkesztői és kiadói múltját - amikor is a Délmagyarországot „keresztény politikai napilapként” jelentette meg - is fölrótta, s a páter miniszteri (sőt, miniszterelnöki) ambícióinak eszközeként értelmezte a sajtóügyekben és a papírkiutalásokban tanúsított magatartását. ${ }^{231}$

A kommunista Szabad Nép is keményen fogalmazott. „A papírkérdés nem tizedrangú, hanem elsőrendü politikai kérdés. A nyomtatott szó: a demokrácia fegyvere. Nem engedhetjük, hogy a reakció alattomos eszközökkel kicsavarja kezünkből a fegyvert." (Balogh nevét azonban ez a cikk nem említette.) ${ }^{232}$

Marosán György - akkor szociáldemokrata, később kommunista politikus, majdani miniszter - a Világosság hasábjain nyíltan támadta Balogh pátert, amikor föltette a kérdést: „Miért nem veszik ki a sajtó irányítását és vezetését annak a kezéből, aki azt eddig is a pártok határozatával ellentétes szellemben csinálta?” Majd hozzátette: „Követeljük, hogy a sajtó ellenőrzését és vezetését Millok Sándor és Kállai Gyula államtitkárok kezébe tegyék le.”233 Ennek a követelésnek meg is lett az eredménye, hiszen a sajtóügyek intézése átkerült Kállai Gyula - kommunista politikus, az 19501960-as években különböző minisztériumok vezetője, majd kormányfő - irányítása alá.

A papírhiány miatt kialakult nehéz helyzetet - és pártpolitikai konfliktust - a koalíciós szervezetek képviselői az 1945. augusztus 1-jei pártközi értekezleten tárgyalták. Itt elfogadták Rónai Sándor azon javaslatát, amely szerint a fővárosi hírlapok

\footnotetext{
${ }^{230}$ Népszava, 1945. július 19.

${ }^{231}$ Népszava, 1945. július 21.

${ }^{232}$ Szabad Nép, 1945. július 19.

${ }^{233}$ Világosság, 1945. július 20.
} 
naponta négy, vasárnaponként hat oldal terjedelemben jelenjenek meg; az orgánumok öt százalékkal csökkentsék példányszámukat; a Mai Nap és a Reggeli Újság pedig átmenetileg szüneteltesse a megjelenést. ${ }^{234}$

Az Ideiglenes Nemzeti Kormány elnöke, Miklós Béla 1945. augusztus 20-án rádióbeszédet intézett a határon túli magyarokhoz. A szónoklat szövege a miniszterelnöki hivatal általános iratai között a Miniszterelnök úr Szent István napi rádiószózata a határon túli magyarokhoz címmel maradt fönn. A gépelt szöveg mellett glosszában olvasható a megjegyzés, miszerint a ,szöveget Balogh á[llam]t[itkár]. úr készítette". 235

A beszéd tartalmában fölbukkan mind a korszak „népi demokratikus” frazeológiája, mind Balogh páter korabeli publicisztikájának meglehetősen baloldalinak és szovjetbarátnak tekinthető szókészlete és hangneme. A miniszterelnök - Balogh fogalmazta beszédében - elismerte az ország náci német megszállás miatt bekövetkező romba dőlését, ennél azonban, úgy vélem, fontosabb, hogy az államnak a szovjet Vörös Hadsereg általi megszállását fölszabadulásnak nevezte. „A világ legvéresebb háborúja a mi országunkat is mélyen végigszántotta. Amikor a nagy szövetségesek közül a Szovjetunió győzedelmes vörös hadserege felszabadította országunkat a szörnyü német uralom alól, hajdan virágzó hazánk helyén romba dőlt országot találtak."236

A beszéd a határon túli magyarokhoz szólt. Különös aktualitása volt a szövegnek 1945 későnyarán, több szempontból is. Egyrészt augusztus huszadika, az államalapító Szent István király ünnepe hagyományosan a magyar összetartozás és a nemzeti egység ünnepe. Másrészt pedig az ismét a (trianoni) határokon kívülre rekedt magyarok nehéz helyzetben voltak, hiszen a szomszédos államokban az impériumváltás miatt a magyar nemzetiségüek üldöztetésnek voltak kitéve, sőt - Jugoszláviában brutális etnikai tisztogatásokra is sor került.

A miniszterelnök beszédéböl azt az 1945 utáni magyar baloldali ideológiai elemet olvashatjuk ki, amely szerint a nemzeti(ség)i kérdés megoldását hordozza az, hogy a magyar állam határain belüli és azon túli magyarság - országhatártól függetlenül - azonos politikai blokkhoz (gyakorlatilag, ezt persze nem lehetett nyíltan kimondani, a szovjet érdekszférába) tarozik. „Most, hogy mi is beléphettünk a szabadságszerető népek nagy családjába - boldogan látjuk -, leomlottak azok a válaszfalak, amelyek

\footnotetext{
${ }^{234}$ Kis Újság, 1945. augusztus 2.

${ }^{235}$ MOL XIX-A-1-j-7065-III-1945 1.

${ }^{236}$ MOL XIX-A-1-j-7065-III-1945 1.
} 
benneteket tőlünk, itthoni magyaroktól elválasztottak"237 - hangzott el a Magyar Rádióban 1945. augusztus 20-án.

A kormányfő a határon túli magyaroknak azt javasolta, hogy egyszerre legyenek hü polgárai az államnak, amelynek területén élnek, s a magyarság össznemzeti ügyének elkötelezett hívei. „A békeszerződések előestéjén különös fontossággal esik latba, hogy minden az óhazától távol élő magyar amellett, hogy hű polgára az őt befogadó országnak, a természet törvénye alapján szolgálja a magyar ügyet magatartásával, érdeklődésével, áldozatkészségével és változatlan hüségével. Mindenki azon az őrhelyen, ahol szolgálatot teljesít, arra törekedjék minden erejével, hogy hazánk és népünk jövője boldogabb legyen, mint múltja volt."238

A rádióbeszéd előzményeihez tartozik, hogy Ács Tivadar, a Magyarok Világszövetsége elnöke 1945. augusztus 2-án levélben fordult Miklós Béla miniszterelnökhöz, amelyben közölte a kormányfövel: röpirat kiadását tervezik, amelyben egyebek mellett a következőket kívánják megfogalmazni. „Ki kellene emelni, hogy a Szovjet támogatása tette lehetővé a demokratikus átalakulást $\mathrm{s}$ e hatalmas köztársaság bizalma biztosíthatja nemcsak azt, hogy a reakciós rendszer nem tér vissza, de jövő boldogulását $\mathrm{s}$ azt is, hogy szomszédjainak demokratikus népe a demokrata Magyarország népével őszinte, zavartalan jó barátságban élhet. Csak ez simíthatja el a határkérdések okozta bonyodalmakat, spirituálhatja a határokat, egyedül ez alkalmas arra, hogy a határokon túli magyarság magyar életet élhessen nemzeti és egyéni érvényesülése sérülése nélkül."239

Ezek a gondolatok - láthattuk - visszaköszönnek a beszédben.

1945 szeptemberében a sajtóügyek és az engedéllyel rendelkező lapok papírellátása a korábbiaknál nagyobb hangsúlyt kapott, hiszen 1945. november 4-én tartották a nemzetgyülési választásokat. A választási küzdelembe a Magyar Nemzeti Függetlenségi Frontban tömörült pártok (Független Kisgazdapárt, Magyar Kommunista Párt, Szociáldemokrata Párt, Nemzeti Parasztpárt) mellett a Polgári Demokrata Párt amely 1945 májusáig volt tagja a függetlenségi frontnak - és a Magyar Radikális Párt is bekapcsolódott. A pártok többsége nemcsak országos, hanem sok vidéki városban helyi lapot is kiadott. A papírkiutalásokkal kapcsolatos miniszterelnökségi iratok átnézve arra

\footnotetext{
${ }^{237}$ MOL XIX-A-1-j-7065-III-1945 3.

${ }^{238}$ MOL XIX-A-1-j-7065-III-1945 4.

${ }^{239}$ MOL XIX-A-1-j-5875-III-1945 4.
} 
a megállapításra juthatunk, hogy a kommunista sajtó nagyobb mennyiségü papírt kapott, mint a választásokon induló többi szervezethez kötődő orgánum.

Kállai Gyula miniszterelnökségi államtitkár 1945. szeptember 1-jén betiltotta a budapesti Galilei Kör Kritika címü lapját. A betiltásról rendelkező irat glosszájában Kállai a következőket fogalmazta meg: „A Korondi András felelős szerkesztésében Budapesten megjelenő »Kritika« című kéthetenként megjelenő szemle az előiratok tanúsága szerint Balogh államtitkár úr engedélye alapján jelent meg. Tekintettel arra, hogy a kérelmet a Szövetséges Ellenőrző Bizottság nem látta, így engedély nélküli lapnak minősül, miértis betiltandó."240

Donászy Kálmán, a kisgazdapárt szegedi ügyvezető elnöke 1945. szeptember 14-én írt a miniszterelnökség sajtóosztályának. „A Független Kisgazda, Földmüves és Polgári Párt szegedi szervezete azt a kérelmét terjeszti elö, hogy részére napilap megjelentetésére jogosító engedélyt kiadni, illetőleg a már meglévő hetilap engedélyét napilap engedélyre átváltoztatni szíveskedjék. Szegeden és az egész DélMagyarországon ezidő szerint a Kisgazda Pártnak nincs egyetlen napilapja sem, amíg ugyanakkor a Kommunista Párt és a Szociál Demokrata párt mind Szegeden, mind pedig a környező városokban számos napilappal rendelkezik. A választásoknál minden pártra egyaránt érvényes és egyenlő feltételek elve ezáltal súlyos sérelmet szenved. Mindezekre tekintettel kérjük, hogy a napilap engedélyt sürgősen kiadni szíveskedjék. Megjegyezzük, hogy a megindítandó napilap papírszükséglete egyelőre fedezve van. A napilap címe »Szegedi Frissújság«, felelős szerkesztője Dr. Donászy Kálmán."241 Erre az engedélyt 1945. október 1-jén adta meg Kállai Gyula miniszterelnökségi államtitkár. ${ }^{242}$

Balogh István négy hónappal korábban, 1945. április 24-én adott engedélyt a Független Kisgazdapárt szegedi elnökségének küldött levelében helyi pártlap kiadására. „Megengedem - írta az államtitkár -, hogy »Szegedi Hírlap /: tanyai újság:/« címen hetenkint megjelenő politikai lapot indítson, 4 oldal terjedelemben, az utcai árusítás jogával. A példányszámot később fogom megállapítani."243

1945 szeptemberében a papírelosztásban Kállai Gyula miniszterelnökségi államtitkár és Pál Gyula papírgazdálkodási miniszteri biztos (később helyette Vámos

\footnotetext{
${ }^{240}$ MOL XIX-A-1-j-7514-V-1945 1-2.

${ }^{241}$ MOL XIX-A-1-j-7619-V-1945 3-4.

${ }^{242}$ MOL XIX-A-1-j-7619-V-1945 6.

${ }^{243}$ MOL XIX-A-1-j-7619-V-1945 2.
} 
György) volt az illetékes. 1945. október 12-én a Polgári Demokrata Párt Világ címü lapjának $^{244}$, október 15-én pedig a Magyar Radikális Párt Haladás címü újságjának utaltak ki ezerötszáz kilogramm rotációs papírt. ${ }^{245}$ Az engedély szerint mindkét lap nyolc oldal terjedelemben, negyvenezer példányban jelent meg. Úgy látszik, a választási kampányban ügyeltek a vidéki kommunista sajtó papírellátására is, hiszen a két országos pártorgánumnál nagyobb mennyiségü - kétezer kilogramm tömegü - papírt kapott például a Magyar Kommunista Párt kecskeméti lapja, a Kecskeméti Szabad Nép. ${ }^{246}$ A kommunistabarát agrárszervezet, a Földmunkások és Kisbirtokosok Országos Szövetsége Dózsa Népe címü, Hunya István szerkesztette hetilapjának ezerhatszáz kilogramm papírt utaltak ki. ${ }^{247}$

1945. december 5-én Kállai államtitkár a koalíciós párt szegedi lapjainak egyenként négyezer kilogramm papírt utaltatott ki: a kommunista Délmagyarországnak, a szociáldemokrata Szegedi Népszavának és a kisgazda Szegedi Hírlapnak. A Délmagyarország és a Szegedi Hirlap naponta négy oldal terjedelemben jelent meg, az előbbi tízezer, az utóbbi tizenötezer példányban. ${ }^{248}$

Balogh Istvánnak miniszterelnökségi államtitkárként 1944 decemberétől fontos szerepe volt az Ideiglenes Nemzeti Kormány sajtópolitikájának alakításában, amelyben a Magyar Nemzeti Függetlenségi Frontban részt vevő pártok lapjainak engedélyezése és papírral való ellátása prioritást élvezett. Balogh páter 1945 áprilisáig szabadon engedélyezte vagy tiltotta meg a lapkiadást, onnantól kezdve azonban az ország szuverenitását - az 1945. január 20-i fegyverszüneti egyezmény értelmében - korlátozó, szovjet vezetés alatt álló Szövetséges Ellenőrző Bizottság jóváhagyása is szükségessé vált a sajtótevékenységhez.

A Balogh-ellenes 1945. júliusi baloldali támadások következtében a sajtóügyeket a kommunista Kállai Gyula államtitkár vette át. Ennek következtében 1945 szeptemberében -a fóvárosi törvényhatósági, majd a parlamenti választási kampány idején - már kimutatható, hogy a kommunista lapok nagyobb mennyiségü papírhoz jutottak.

\footnotetext{
${ }^{244}$ MOL XIX-A-1-j-9390-V-1945

${ }^{245}$ MOL XIX-A-1-j-9533-V-1945

${ }^{246}$ MOL XIX-A-1-j-9533-V-1945

${ }^{247}$ MOL XIX-A-1-j-7626-V-1945

${ }^{248}$ MOL XIX-A-1-j-11561-V-1945
} 
Valószínűleg Balogh is megőrzött valamennyit régi befolyásából, hiszen biztosítani tudta saját lapjai (Magyar Nemzet, Mai Nap) zavartalan megjelenését.

Baloghnak, mint a miniszterelnökséget vezető államtitkárnak egyébként jóval nagyobb hatásköre volt, mint a többi minisztériumban szolgálatot teljesítő államtitkárnak, hiszen - a kormányfő fölhatalmazása alapján - például joga volt utasítani kormánytagokat is. Így utasította Rácz Jenő kisgazdapárti pénzügyminisztert 1946. szeptember 17-én, hogy a béke-előkészítő alap javára fizessen ki százezer dollárt, 1946. október 3-án pedig kézzel írt levelében arra, hogy annak ellenében fizessen ki Jékely Lászlónak - a levél kézbesítőjének - harmincezer dollárt. ${ }^{249}$

Balogh kormányzati befolyásáról Kovács Imre - aki még mint a Nemzeti Parasztpárt főtitkára találkozott vele először - a következőket jegyezte föl: „Mindjárt realizáltam, hogy az aranykeretes szemüvege mögül mosolygó, rózsaszín arcú, százötven kilós pap az ész a kormányban..." ${ }^{250}$ De ugyanezt állapította meg róla politikai ellenfele, Sulyok Dezső is: „Balogh István volt a kormány, illetve az Ideiglenes Nemzetgyülés esze." 251

Rákosi Mátyás is hasonló módon emlékezett vissza az 1944-1945-ös időszakra, amikor is Balogh páter „lett lassanként a kisgazdapárt »szürke eminenciása«, aki mint miniszterelnökségi államtitkár a háttérből rángatta a szálakat" és Miklós Béla kormányfö mellett „tulajdonképpen ő vezette a miniszterelnökséget, ő írta az elnök beszédeit, elhelyezte a maga embereit, s mire mi felfigyeltünk rá, alaposan befészkelte magát az államapparátusba". ${ }^{252}$

Ilyen bizalmi embere volt Balogh páternek Bojta Béla (1899-1969) - született Burger Ernő, szegedi ügyvéd - akit előbb a miniszterelnökségre nevezett ki előadónak, majd osztálytanácsosnak, később kijárta államtitkári kinevezését, illetve támogatta abban, hogy a Népbíróságok Országos Tanácsának elnöke legyen. ${ }^{253}$

\footnotetext{
${ }^{249}$ Politikatörténeti és Szakszervezeti Levéltár (a továbbiakban: PIL) 274. f. 7/227. ő. e. 4-5.

${ }^{250}$ Kovács Imre: Magyarország megszállása. Budapest, 1990. (a továbbiakban: Kovács Imre, 1990) 233.

${ }^{251}$ Sulyok Dezső: Két éjszaka nappal nélkül. Ford. K. Vladár Edit. Budapest, 2004. (a továbbiakban: Sulyok Dezső, 2004.) 53.

${ }^{252}$ Rákosi Mátyás: Visszaemlékezések. 1940-1956. 1. köt. S. a. r., jegyz.: Baráth Magdolna, Feitl István, Gyarmati György, Palasik Mária, Sipos Levente, Szücs László, T. Varga György. Budapest, 1997. (a továbbiakban: Rákosi Mátyás, 1997) 396.

${ }^{253}$ MOL XIX-A-1-j-369-IV-1945
} 
A szegedi kisgazda politikus, Pálffy György (1904-1970) - előbb az alföldi város polgármester-helyettese, majd föispánja - Balogh István támogatottjai közé tartozott. A páter közbenjárt főispáni kinevezésekor, majd Tildy Zoltán kisgazda pártelnökkel együtt 1945 augusztusában arra kérte Erdei Ferenc belügyminisztert, adományozzon címzetes államtitkári rangot Pálffynak. Ezt Erdei meg is tette, ám Zsedényi Béla házelnök - mint az államföi jogkörök egy részét gyakorló Nemzeti Főtanács elnöke - elutasította a javaslatot. ${ }^{254}$

Balogh István politikusi és szervező képességeiről Sulyok is - ugyan elég maliciózusan - elismerően szólt. „Balogh a maga 130 kilós súlyával a várakozásomnak megfelelő benyomást tette rám. Nem okos, hanem ravasz és ügyes politikus volt. A politika orgonáján az alsó regiszterbe tartozó futamokat tökéletesen játszotta; nagymestere volt az intrikának és a fondorlatoknak. Mesterien értett ahhoz, hogy érdekközösségeket építsen ki, különösen kéz kezet mos alapon. Még igazi politikussá fejlődhet, aki látszólag a legjobbak közé tartozik. Államférfiként azonban hiányzik belöle a magyaroknak az a tulajdonsága, ami a nemzet gyökerét alkotja; olyan magyarság, amely kész az életét is feláldozni. Röviden, hiányzik belöle a haza érdekében mindent kockára tevő bátorság." 255

A Magyar Kommunista Párt a koalíciós kormányzás kezdeti időszakától kezdve igyekezett megszerezni minél fontosabb kormányzati pozíciókat. Ennek szellemében már 1945 tavaszán szerették volna a miniszterelnöki hivatalt vezető államtitkárt delegálni, illetve - ha erre nem lett volna lehetőség -, legalább egy újabb miniszterelnökségi államtitkári tisztséget létrehozni és azt saját hívükkel betölteni Révai József 1945. április 4-én Debrecenben - a kormány akkori székhelyén - kelt jelentésében tájékozatta Gerő Ernőt, hogy „be fogjuk jelenteni igényünket a miniszterelnökségi államtitkárságra, vagy legalább egy másodikra Baloghé mellett."256 Az újabb kinevezésekre - miközben az első államtitkár továbbra is Balogh páter maradt - két hónapot kellett várni. A kommunista Kállai Gyulát és a szociáldemokrata Millok Sándort 1945. június 8-án nevezték ki miniszterelnökségi államtitkárrá.

A kommunisták azonban nem nézték jó szemmel, hogy Balogh egyre inkább meghatározó kormányzati tényezővé vált. A páter kormányzati térnyerésének példája, hogy 1945. április 20-án másnap délelőttre - saját nevében, a Vörös Hadsereg ellátásnak

\footnotetext{
${ }^{254}$ MOL XIX-A-1-j-6737-III-1945

${ }^{255}$ Sulyok Dezső, 2004. 53-54.

${ }^{256}$ PIL 274. f. 7/24. 49.
} 
ügyében - pártközi értekezletet hívott össze. ${ }^{257}$ De ő vezette az 1945. április 28-i pártközi egyeztető tárgyalást is, amelyen a gazdasági élet újjászervezésének kérdései kerültek napirendre. ${ }^{258}$

Az MKP Központi Vezetősége 1945. április 14-i ülésén elhatározta: javasolja a koalíciós pártoknak, illetve a kormányfőnek, hogy kezdjenek tárgyalásokat a kormány rekonstrukciójáról. Alapvető követelésként fogalmazták meg ekkor Faragho Gábor közellátásügyi miniszter, illetve Balogh István miniszterelnökségi államtitkár menesztését. ${ }^{259}$ Végül a kormány átalakítására 1945. július 21-én került sor. Ekkor az igazságügy-miniszteri székben Valentiny Ágostont Ries István váltotta, a pénzügyminiszter Vásáry István helyett Oltványi Imre lett, míg a közellátásért felelős miniszteri bársonyszéket a kommunistabarát szociáldemokrata Rónai Sándor foglalhatta el. Balogh István a helyén maradt.

\section{2. Kapcsolata a Délmagyarországgal az 1940-es években ${ }^{260}$}

Balogh István 1944 végén részt vett a németellenes és demokratikus erőket tömörítő Magyar Nemzeti Függetlenségi Front és a Szegedi Nemzeti Bizottság megszervezésében. Ezen szervezetek rendelkezésére bocsátotta a patinás - és mind a mai napig megjelenő - szegedi hírlapot, a Délmagyarországot, amelynek egy ideig egyik tulajdonosa is volt.

Ebben a fejezetben Balogh páter és a Délmagyarország kapcsolatához közlök adatokat, elsősorban az 1944 és 1946 közötti időszakra fókuszálva. Ezekben az években ugyanis az Ideiglenes Nemzeti Kormány, majd a koalíciós kormány államtitkáraként meghatározó és befolyásos pozíció jutott Baloghnak. Egyaránt vizsgáltam az általa írt publicisztikai - elsősorban aktuálpolitikai kérdéseket tárgyaló - írásokat, valamint a róla

\footnotetext{
${ }^{257}$ PIL 283. f. 10/242. 3.

${ }^{258}$ PÉ, 2003. 40-44.

${ }^{259}$ PIL 274. f. 4/33. 4.

${ }^{260}$ Lásd bővebben: Miklós Péter A páter és a hírlap. Balogh István politikai pályájának kezdetei és a Délmagyarország. In: A Móra Ferenc Múzeum Évkönyve. Történeti Tanulmányok - Studia Historica. 10. kötet. Szerk. Zombori István. Szeged, 2007. 167-192.
} 
megjelent cikkeket, tudósításokat és a vele készített interjúkat. Ezzel képet kaphatunk arról, hogyan ítélte meg a szegedi kommunista csoport - hiszen a Délmagyarország 1945 júliusától az MKP helyi lapja volt - Balogh István politikai tevékenységét a koalíciós évek első időszakában. ${ }^{261}$

A Délmagyarországot Róna Lajos 1910-ben alapította. Ez Szeged város leghosszabb életű lapja. Első száma 1910. május 22-én jelent meg. Később Róna Lajostól Pásztor József vette át a tulajdonjogot és a szerkesztést. Kezdetben a lapnak főleg az irodalmi rovata volt értékes. Ady Endrének, Kosztolányi Dezsőnek, Krúdy Gyulának jelentek meg írásai hasábjain. 1918-tól Juhász Gyula is a munkatársak közé tartozott. 1920 és 1925 között Szeged címmel jelent meg: az újságot ugyanis betiltották, de szerkesztői és munkatársai nem tántorodtak el, így más néven adták ki - változatlan készítőkkel és szellemiséggel - a lapot.

Az első zsidótörvény és a sajtórendészeti törvény alapján a zsidó származású Pásztor Józsefnek - a Délmagyarország Hírlap- és Nyomdavállalat főrészvényesének el kellett adnia a lapot. A vevő formailag Balogh János volt, de valójában bátyja, Balogh István kezébe került a lap. Balogh páter 1939. január 6-án rányomtatta a lap fejlécére - hasonlóan a korszak helyi jobboldali hírlapjához, a Szegedi Új Nemzedékhez -, hogy „keresztény politikai napilap”, de igyekezett megőrizni a Délmagyarország liberális és demokrata jellegét. Balogh megtartotta az újság addigi munkatársait is. Azonban Pásztor József följelentette a papot Glattferdernél, aki „leparancsolta Balogh pátert a közélet színteréröl”, és fölszólította, hogy adja el a lapot.

1939-ben a szegedi szabadtéri játékok számára Szeged város által biztosított támogatásból megtakarításként 610 pengő maradt. ${ }^{262}$ Az 1939. december 21-i városi közgyülés elhatározta, hogy ezt az összeget átadja az Ünnepi Játékrendező Kft.-nek. Dékány Sándor, városi főszámvevő azonban csak 473 pengőt utalt át a társaságnak. Ezért az Ünnepi Játékrendező - amelynek Balogh is tulajdonosa volt - a maradék 137 pengőért pert indított a város ellen. Az ügyet részletesen megírta Délmagyarország is, s

\footnotetext{
${ }^{261}$ Az ehhez az alfejezethez szükséges anyaggyüjtésben segítségemre volt Urbán Marianna, aki ebben a témakörben készült egyetemi szakdolgozatát, valamint az ahhoz készített jegyzeteit a rendelkezésemre bocsátotta. Lásd: Urbán Marianna: Balogh István politikája és publicisztikája 1944-1946-ban. Szeged, 2006. Szakdolgozat. Témavezető: Miklós Péter. (Kézirat, SZTE BTK)

${ }^{262}$ Délmagyarország, 1939. december 16.
} 
Dékány személyes felelősségét hangsúlyozta, aki a közgyülési határozattal ellentétesen intézkedett. $^{263}$

Glattfelder 1940. február 10-én saját kezüleg írt az ügyben Balogh Istvánnak. Egy vezető városi tisztviselő ugyanis közbenjárt nála Dékány főszámvevő érdekében, aki „üzleti elszámolási ügyben kötelességszerüen a város álláspontját képviselte”. A püspök - akinek valószínüleg már kellemetlen volt az állandó magyarázkodás Balogh írásai miatt - ultimátumot adott az alsóközponti plébánosnak: vagy megszakít minden kapcsolatot a sajtóval, vagy nyugdíjba kell vonulnia. „Kifejtettem Önnek már ismételten, mily tapintatot tételez fel papi jellege az újságszerkesztéssel kapcsolatban tekintettel a mi jóindulatú közéleti tényezőink érzékenységére is. Ha ennek dacára ezt a müveletet nem tudja lebonyolítani kötekedő személyeskedés nélkül, akkor nem marad más hátra mint az a választás, hogy vagy megszüntet minden kapcsolatot a sajtóval vagy nyugdíjazását kéri $\mathrm{s}$ ezt a döntést kibúvót kizáró módon fognám félreértés esetén provokálni." ${ }^{264}$ - írta a föpap.

Balogh 1940. február 12-én válaszolt a püspök levelére. Kifejtette, hogy a föszámvevő nem a város érdekében járt el, hanem nem teljesítette a szerződésben vállalt kötelezettséget, amikor nem fizette ki a teljes összeget (610 pengő). „Sajnos nem üzleti elszámolásról van jelen esetben szó, hanem arról, hogy a város nem teljesítette szerződésben vállalt azon kötelességeit, melyeket a város közönségét képviselő törvényhatósági bizottság egyhangúlag vállalt és a belügyminiszter, mint kormányhatóság jóváhagyott, ezért eminenter ${ }^{265}$ közügyről van szó, nem pedig magánérdeket szolgáló üzleti elszámolásról."266 Balogh szerint a Délmagyarország közügyet szolgált, amikor tudósított az ügyről, amely fontos a szabadtéri játékok jövője szempontjából. „Szerény véleményem szerint a Délmagyarország közérdeket szolgált, amikor a főszámvevő úrnak súlyos felelősségét, különösen a játékok jövője szempontjából, megállapította.,267

A plébános közölte, hogy a Délmagyarország nem is foglalkozott Dékány személyével - miután érdekében egy jezsuita atya járt közben. Ugyanakkor fölhívta a figyelmet a Szegedi Új Nemzedék című napilapra, amely szélsőjobboldali nézeteknek is

\footnotetext{
${ }^{263}$ Délmagyarország, 1940. január 11.

${ }^{264}$ SZCSPL PHEI 506/1940.

${ }^{265}$ Eminenter $=$ legföképp, kiváltképp.

266 SZCSPL PHEI 506/1940.

${ }^{267}$ SZCSPL PHEI 506/1940.
} 
teret adott. „Kegyelmes Uram! Ne méltóztassék fegyelmezetlenségnek venni, de önkéntelenül feltör bennem a kérdés: vajon az a dignitárius, aki annyira a szívén viseli a katolikus ügyeket, tett-e jelentést Excellenciádnak akkor, amikor a katolikus közpénzekből segélyezett Szegedi Új Nemzedék a hivatalos egyház által ellenségesnek minősített nyilas mozgalmat nemcsak támogatta, hanem szerkesztőségébe szervezte...?"268

Ezzel szemben Szeged-Alsóközpont plébánosa rámutatott, hogy a Délmagyarország - olykor kritikus hangnemben is - mindig a város érdekeit és a keresztény nemzeti gondolatot kívánta szolgálni. „Amikor 1938. év végén más érdekcsoportokkal szemben sikerült a Délmagyarországot megszerezni és azt az egyház és a katolikus magyarság szolgálatába állítani, azt hittem, helyes dolgot cselekszem. A papság egy része oda is állt a Délmagyarország mellé, a legintelligensebb katolikus rétegek pedig örömüknek adtak kifejezést, hogy végre van politikumtól nem befolyásolt s kizárólag katolikus közérdek szolgálatában álló lap is Szegeden. Persze volt mindig és van ma is egy tábor, melynek éppen más irány tetszenék, ha éppen a katolikum rovására is. ${ }^{2} 269$

A levél végén Balogh közölte, hogy - igaz, külső nyomásra - megválik a Délmagyarországtól. Sőt az is fölvetődött, hogy a lapot össze lehetne vonni a Szegedi Új Nemzedékkel, hiszen egy városban elegendő egy keresztény nemzeti elkötelezettségü újság. „Bennem tehát nem csak a készség van meg, de a legszigorúbb elhatározásom, melyben Nagyméltóságod atyai levele csak megerősített, hogy a laptól megválok. Adja Isten, hogy másvalaki biztosabb szemmértékkel és több tapintattal s így nagyobb sikerrel is intézze majd a lap ügyeit.",270

Glattfelder 1940. február 13-i levelében megnyugvásának adott hangot, hogy papja más kiadónak adja át a Délmagyarországot. Ám figyelmeztette Baloghot, hogy amíg az újság megjelenésében szerepet vállal, fogalmazzon óvatosabban, és ne gyüjtsön magának további ellenségeket. „Azt látom, hogy egy tanyai plébános számára emberfölötti feladat szegedi lapot irányítani s ugyanakkor lelkipásztori feladatainak is megfelelni s ha e dilemmából szerencsés kiutat talál, azért csak dicsérni fogom. De

\footnotetext{
268 SZCSPL PHEI 506/1940.

${ }^{269}$ SZCSPL PHEI 506/1940.

${ }^{270}$ SZCSPL PHEI 506/1940.
} 
addig is míg ez megtörténik, vigyázni kell, hogy az embereket ne mérgesítsük, hanem az igazságot és a jó ügyet szolgáljuk."271

Ekkor vette meg Berey Géza a Délmagyarországot. Ö lett 1940. június 12-étől a lap főszerkesztője, felelős kiadója és a Délmagyarország Hírlap- és Nyomdavállalat ügyvezető igazgatója. 1944-ben Bereyt a Gestapo letartóztatta, később Dachauba vitték és 1944. április 16-án a lapot is betiltották. 1944 novemberében Révai és Erdei látogatása után indulhatott újra. November 14-én foglalta el helyét a szerkesztőség a Szeged, Jókai u. 4. számú ház emeletén. Kiadóként a Hírlapkiadó Kft. szerepelt az impresszumban, amelyet külön erre a célra alakítottak. A felelös kiadó a kommunista nyomdász, Koncz László volt.

1944 szeptemberétől a Vörös Hadsereg bevonulásának következményeként Magyarország a náci németek által megszállt országból a kommunista szovjetek által megszállt országgá vált. A fővárosban, az ország középső és nyugati területén pedig a Szálasi-diktatúra élte végóráit. Kelet-Magyarországon új hatalmi szervek - népi, majd nemzeti bizottságok - alakultak. Az első várost, Makót a szovjet csapatok szeptember 25-én foglalták el. Nem sokkal később Szeged - földrajzi helyzetének, tudományos, társadalmi és infrastrukturális adottságainak köszönhetően - egy időre az országos politika központja lett. Itt kapcsolódott be a politikai életbe Balogh István.

1944. október 11-én fehér zászlót tűztek a szegedi városháza tornyára. Ezzel fejezték ki, hogy a város ellenállás nélkül kívánta megadni magát. Október 15-én Szegedre érkezett Vas Zoltán és két nappal később megalakult a Kommunisták Magyarországi Pártjának szegedi szervezete. 1944. november 5-én, miután Gerő Ernő, Farkas Mihály, Nagy Imre és Révai József is a városba jött, megalakult a Magyar Kommunista Párt Központi Vezetősége. Ekkor tisztázták a párt helyes nevét, szerepét a demokratikus többpártrendszerben és a megindítandó lap jellegét. ${ }^{272}$

Ezen a ponton, 1944 novemberében Balogh páter bekapcsolódott az újrainduló magyar politikai életbe, mint a német megszállás után betiltott liberális-demokrata Délmagyarország kiadója, tulajdonosa. November 12-én alsóközponti plébániáján - a mai Mórahalmon - kereste föl Révai József (a Magyar Kommunista Párt egyik

\footnotetext{
${ }^{271}$ SZCSPL PHEI 506/1940.

${ }^{272}$ Farkas Csaba: A szovjet megszállástól a fordulat évéig. In: Szeged története. 5. köt. 1945-1919. Szerk. Blazovich László. Szeged, 2010. 87-110.
} 
vezetője) és Erdei Ferenc (a falukutató mozgalom és a Márciusi Front ismert baloldali alakja, a Nemzeti Parasztpárt egyik szervezője) a lap újraindításának ügyében. ${ }^{273}$

Valentiny Ágoston, Szeged szociáldemokrata polgármestere javasolta Erdeinek és Révainak, hogy Balogh Istvánnal tárgyaljanak a Délmagyarország újraindításáról. Balogh ekkor valószínüleg elhallgatta előlük, hogy a német megszállás után, 1944. március 22-én lemondott a részvénytársaság elnökségéről és igazgatói tagságáról. Pedig jegyzőkönyv is készült az eseményről: „A közgyülés az elnöki bejelentéseket elfogadja, illetve tudomásul veszi, dr. Balogh István lemondását sajnálattal tudomásul veszi, s eddigi müködéséért - jegyzökönyvi köszönetet mond." Ekkor törölték nevét a cégbíróságon az igazgatósági tagok sorából. ${ }^{274}$

A politikusok 1944. novemberi szeged-alsóközponti találkozójukon megállapodtak abban, hogy a lapot szerkesztőbizottság irányítja. Tagjai a kisgazdapárt részéről Balogh István (gazdasági főnök), a parasztpárt részéről Erdei Ferenc (főszerkesztő) és a kommunista párt részéről pedig Révai József (fömunkatárs). ${ }^{275}$

A Magyar Kommunista Párt Központi Vezetősége - Gerő Ernő, Farkas Mihály, Révai József és Nagy Imre - 1944. november 7-én ülésén határozatot hozott egy „demokratikus napilap kiadásáról”. Döntöttek arról is, hogy „Révai elvtárs megbízatik a lap kiadásával kapcsolatos előkészületi munkákkal. A lapnak legkésőbb két héten belül meg kell jelennie."276 November 12-én a Központi Vezetőség elfogadta a Nemzeti Parasztpárttal és a Független Kisgazdapárttal kötött megállapodást, amely egyrészt a lap megjelentésének anyagi körülményeit rögzítette, másrészt a meghatározta az orgánum politikai irányvonalát ${ }^{277}$, amelyet néhány nappal később meg is jelentettek a Délmagyarország november 21-i számában. ${ }^{278}$

A Délmagyarországot a szegedi bejegyzésü Hírlapkiadó Kft. adta ki, amelynek hat egyenlő arányban tulajdonrésszel bíró tulajdonosa volt: Balogh páter és Csányi

\footnotetext{
${ }^{273}$ Péter László: Amikor Szegeden dobogott az ország szíve. In: Uő: A szerette város. Budapest, 1986. (a továbbiakban: Péter László, 1986) 138-139.

${ }^{274}$ Péter László: A Délmagyarország fordulópontjai. In: Uő: A Város cselédje. Szeged, 2006. (a továbbiakban: Péter László, 2006) 29-30.

${ }^{275}$ Balázs György, 1984. 234-235.

${ }^{276}$ PIL 274 f. 2/1. ő. e. $1-2$.

${ }^{277}$ PIL 274. f. 7/143. ö. e. 1-2.

${ }^{278}$ PIL 274. f. 2/2. ö. e. 1-2.
} 
Piroska (FKGP), Erdei Ferenc és Erdei Sándor (NPP), valamint Dénes Leó és Koncz László (MKP). ${ }^{279}$

Később, 1945 tavaszán azonban a tulajdonosok között konfliktusok keletkeztek, a kommunisták ugyanis egyre nagyobb befolyást akartak szerezni a lap irányítására. 1945. március 29-én Magyar László felelős szerkesztő helyére Szirmai Istvánt nevezte ki Koncz László - a többi tulajdonos megkérdezése nélkül. Mikor ezt Csányi Piroska szóvá tette, Szirmai azt mondta neki, hogy ő egyedül Koncznak tartozik felelősséggel. Csányi ezért az akkor már miniszterelnökségi államtitkárként dolgozó Balogh páterhez fordult segítségért, akivel közölte, hogy az FKGP helyi csoportja egyáltalán nem bízik Szirmai Istvánban. A Délmagyarországról pedig megjegyezte: „A lap szellemi színvonala pedig a lehető legalacsonyabb nívóra süllyedt, amióta ismét - félkézzel, mert félkézzel földet oszt, - ő csinálja és a legcsúnyább magyartalanságok és helyesírási hibák /!/ jelennek meg benne."280

Balogh Csányi Piroska levelét saját kísérő soraival együtt továbbította Révai Józsefnek. „Novemberben nem így képzeltem az együttmüködést - írta Balogh István. Lelkiismeretem nyugodt, hogy nemcsak türelemmel, de még áldozatok árán is iparkodtam szolgálni azt a békét, amely a pártok együttmüködésének elengedhetetlen feltétele."281 Balogh emlékeztette Révait, hogy Csányi Piroskát, akinek Szirmai rossznak ítélt városházi tudósításaira hivatkozva - újságírói kvalitásait is kétségbe vonta és megtagadta cikkei közlését, érzelmi szálak füzik a Délmagyarországhoz. Nemcsak azért, mert régi munkatársa, hanem azért is, mert férjét, Berey Gézát alig egy évvel korábban onnan hurcolták el a németek (s akkor még nem is tudtak sorsáról semmit, nem értesültek róla, hogy Berey túlélte a koncentrációs tábort). ${ }^{282}$

A Magyar Nemzeti Függetlenségi Frontba tömörült pártoknak a közös sajtótermék kiadása kapcsán jelentkező ellentétei más városokban - így például Kecskeméten - is megfigyelhetőek. ${ }^{283}$ A probléma alapja, hogy az MKP mindenütt döntő befolyást próbált szerezni a lap szerkesztésére. Az ügy Szegeden úgy oldódott

\footnotetext{
${ }^{279}$ PIL 274. f. 7/143. ö. e. 3-7.

${ }^{280}$ PIL 274. f. $7 / 150$. ö. e. 2.

${ }^{281}$ PIL 274. f. $7 / 150$. ö. e. 1.

282 Berey Géza: Hitler-allee. Budapest, 1979. 17-46. és 199-210.

${ }^{283}$ Vö. Miklós Péter: A Kecskeméti Lapok a koalíciós években (1944-1949). In: A Móra Ferenc Múzeum Évkönyve. Történeti Tanulmányok - Studia Historica. 13. kötet. Szerk. Zombori István. Szeged, 2010. $377-388$.
} 
meg, hogy a koalíciós pártok külön-külön jelentettek meg hírlapot (amelyben végre korlátozás nélkül közölhették saját álláspontjukat), a Délmagyarország pedig a kommunistáké lett. ${ }^{284}$

Balogh páter ebben az időszakban ismerkedett meg Vas Zoltánnal, aki később így emlékezett rá: „Balogh Istvánnal, köznevén Balogh páterral 1944 őszén ismerkedtem meg Szegeden. Alsótanyán volt plébános. Kedves ember. Szenvedélye a képgyüjtés, a müvészek pártolója.

- Nemcsak ti, én is olvasom a Bolsevik Párt történetét - mondotta nekem. - Itt tartom az íróasztalomon.

Balogh páter azt hitte magáról, hogy az 1945 utáni évek nagy polgári politikusa. Néha hozzátette - Minden út Rómába vezet. Nem tudom, hogyan, az én utam Moszkvába vezetett. Jó ez nekem, Zoltán? - kérdezte lemondóan. Mert alapjában a maga politikájával a népet, az országot, az egyházat akarta szolgálni." ${ }^{285}$

A Délmagyarország szovjet bevonulás utáni első száma 1944. november 19-én jelent meg. ${ }^{286}$ De a lap irányvonaláról csak pár nap múlva, 21-én írtak. Ezt nyolc pontban foglalták össze, melynek első pontjában kijelentették, hogy a Délmagyarország a független, demokratikus, népi Magyarországért küzd. Fő ellenségeiknek a németeket és a nyilas bérenceket tartja, de következetes kritikát gyakorol a 25 éves Horthyrendszer fölött is. Az irányadók szerint fontos a Vörös Hadsereggel való együttmüködés is. Az orosz hadsereg támogatását mint magyar nemzeti érdekeket tartották fontosnak. „A lap küzd a sovinizmus, a Nagy Magyarországról szóló reakciós ábrándok [...] ellen, melynek köszönhető, hogy Magyarország Németország zsoldosává lett [...]" Föladatuknak tekintették ezen kívül a földreform végrehajtását, valamint „a magyar demokrácia győzelme megszilárdítása érdekében németellenes, demokratikus pártok összefogását” a Magyar Nemzeti Függetlenségi Front keretében. „A lap oda fog hatni, hogy Magyarországnak a németek és nyilas bérenceik uralma alatt álló részén a nép harci cselekedetekkel maga is kivegye részét az ország felszabadításában.” Ha ezt a megállapodást „egészben vagy részben túlhaladottá teszi a helyzet alakulása, úgy ezen külön megállapodást megfelelően módosítani kell, vagy újat kell kötni.” Valamint abban is megállapodtak, hogy „ha az itt lefektetett irányelveknek a lapban való

\footnotetext{
${ }^{284}$ A szociáldemokraták Szegedi Népszava, a kisgazdák Szegedi Hírlap, majd Szegedi Kis Újság, a parasztpártiak Szegedi Szabad Szó címmel jelentettek meg lapot a koalíciós évek Szegedjén.

${ }^{285}$ Vas Zoltán: Akkori önmagunkról. Budapest, 1982. 154-155.

${ }^{286}$ Vö. Vas Zoltán: Viszontagságos életem. Budapest, 1980. 732-740.
} 
érvényesítése körül vagy a pártokat képviselö tagok között [...] ellentétek merülnének fel, [...] úgy a társaság feloszlatására és megszüntetésére vonatkozó rendelkezés lesz végrehajtható.",287

A föntebb idézett megállapodás azért jelentős, mert ez volt az első politikai dokumentum, amelyet a Magyar Nemzeti Függetlenségi Frontban részt vett antifasiszta, demokratikus erők képviselői írtak alá a második világháború utolsó periódusában. ${ }^{288} \mathrm{~A}$ Szociáldemokrata Párt képviselői azért nem voltak az aláírók és a szerkesztőbizottság tagjai között, mert ekkor a párt még nem szerveződött újjá. Szegeden csak decemberben alakult meg az SZDP városi csoportja, de ekkor sem vett részt a Délmagyarország szerkesztésében és kiadásában, hanem Szegedi Népszava címmel önálló lapot indított.

1944 decemberében a szerkesztőbizottság tagjai Debrecenbe mentek az Ideiglenes Nemzetgyülés alakuló ülésére. Ekkortól kapcsolatuk szinte teljesen megszakadt a lappal, de nevük április 8-án - és nem július 24-én, ahogy Péter László írta - került le a címoldalról a szerkesztőbizottság tagjai közül. 1945. július 24-én a Délmagyarország kizárólag a Magyar Kommunista Párt lapja lett. Addig a Magyar Nemzeti Függetlenségi Front lapjaként jelent meg. A kisgazdák a Szegedi Kis Újságot, a Nemzeti Parasztpárt pedig a Szegedi Szabad Szót jelentette meg ezután. ${ }^{289}$

A Délmagyarország újraindításán kívül az 1944. november 12-i tárgyalás alkalmával született meg a résztvevők között Szeged-alsóközpont plébániáján a később Balogh által „szegedi kézfogásként” emlegetett megállapodás, amely a Magyar Nemzeti Függetlenségi Front alapelveit tartalmazta. A koalíciós politika kialakításában így nagy szerepe volt Baloghnak. A programjavaslattal, amelyet Révai készített el és mutatott be neki, jórészt egyetértett. Két tétel módosítását javasolta csupán. Az egyik az volt, hogy ne a kis nyilasok ellen való eljárásról, hanem a felelős nyilasok elleni föllépést sürgessék. A másik, hogy a vallásszabadság mellett az egyház anyagi támogatásának a biztosítását is deklarálják.

November 23-án az újjáalakult Független Kisgazdapárt elnöki tanácsa ülést tartott Szegeden Balogh István elnökletével. A tanács állást foglalt az MNFF magalakítása és a Délmagyarország újraindítása mellett. Ahogy a lap írta: „Az értekezlet egyhangú határozattal helyeslöleg vette tudomásul a pártelnöknek mind a

\footnotetext{
${ }^{287}$ Idézi: Péter László, 2006. 36-38.

${ }^{288}$ Kállai Gyula: A magyar függetlenségi mozgalom története. 1936-1945. Budapest, 1978. 384-392.

${ }^{289}$ Vö. Péter László, 1986. 139-144.
} 
Délmagyarország megindításával, mind a Magyar Nemzeti Függetlenségi Front létesítésével kapcsolatos eljárását."290

A Délmagyarország november 26-i számában írt az FKGP szegedi szervezetének újjáalakulásáról is - bár a lap elején a „tegnapi számot” említik - „A német parancsra feloszlatott Független Kisgazdapárt újra megkezdte" müködését címmel. A lap szerint a párt lelkesedéssel vett részt a Magyar Nemzeti Függetlenségi Front munkájában. A három politikai párt föladatául az orosz hadsereg támogatását és a romokban heverő ország újjáépítését jelölte meg. Néhány nap múlva Balogh István Sürgős program címü cikkében vázolta az ország újrainduló politikai életét és annak föladatait. „Az oroszok által elfoglalt területeken lassan felelevenedik az itt maradt magyarság. Az üzletek redőnyeit felhúzták, a villamos jár, lassan megindul és rendes kerékvágásba zökkent az élet."291

A politikai vezetés kihívásait két pontban jelölte meg. Az egyik, hogy siessenek az újrainduló közigazgatás segítségére, elsősorban a hivatalnokok pótlásával. Elismerte, hogy a müködésüket kezdő pártok közül az MKP volt az első, de jelentkezett „az aléltságából felocsúdó kisgazdapárt is”. Balogh szerint szükség van egy olyan szervre, amely alkalmas a törvényhatósági bizottság pótlására. Javasolta, hogy alakuljanak szakbizottságok, amelyek fölmentik a baloldali pártokat az alól, hogy egyedül viseljék a felelősséget. A másik föladat szerinte olyan politikai szervek kiépítése, melynek keretét a Magyar Nemzeti Függetlenégi Front adná. Az egyes pártok mellé helyi bizottságok fölállítását képzelte el a politikai élet teljessé tételére. A szegedi központhoz a Szegedi Nemzeti Bizottság csatlakozását javasolta, amelynek később ő lett az elnöke. Amíg nincs magyar kormány, addig Balogh szerint azok a pártok képviselik a nemzetet, amelyek tagjai a Magyar Nemzeti Függetlenségi Frontnak. Ez szerinte kiállást és felelősséget igényel, de „senki sem fog visszariadni”. ${ }^{292}$

A Magyar Nemzeti Függetlenségi Front 1944. december 3-án alakult meg hivatalosan, de a korabeli sajtó szerint december 1-jén két hete már, hogy megalakult és dolgozik azon, hogy a nemzet kilábaljon a katasztrofális állapotából és hozzákezdjen az újjáépítő munkához. Előkészítése volt ez az időszak annak, hogy a demokratikus pártok összefogásának lehetőségét és mikéntjét meghatározzák. Ugyanebben a számban (péntek) jelentették be, hogy a Magyar Nemzeti Függetlenségi Front vasárnap fél

\footnotetext{
${ }^{290}$ Délmagyarország, 1944. november 24.

${ }^{291}$ Délmagyarország, 1944. november 26.

292 Délmagyarország, 1944. november 30.
} 
kettőkor a Szegedi Nemzeti Színházban lép a város és az ország nyilvánossága elé és fő céljai a szegedi önkormányzati élet újjáteremtése, valamint politikailag a nemzet talpra állítása. ${ }^{293}$ A függetlenégi fronthoz a Magyar Kommunista Párt, a Szociáldemokrata Párt, a Nemzeti Parasztpárt, a Független Kisgazda-, Földmunkás és Polgári Párt mellett a Polgári Demokrata Párt és a szakszervezetek is csatlakoztak.

Miért együtt? a címe Balogh István 1944. december 3-án megjelent írásának. Ebben arra kereste a választ, hogy hogyan lehet polgári pártoknak a kommunista párttal együttmüködniük. Elvetette a „Goebbels-féle kommunikációt”, amely nem ismer sem Istent, sem családot, sem magánkultúrát, csak vérengzést és kegyetlenséget. Ezzel szemben a kommunisták - bár a vallás iránt közömbösek, de legalább - nem ellenségesek. Balogh szerint a kommunisták a gyermekeket, a családot tisztelik és szeretik, a vérengzést, az elhurcolásokat elvetik. A hadifoglyok nagy részét is hazaengedték már a szovjetek. Ezeket a nyilvánvaló hazugságokat csak tovább tetézte cikkében a páter, amikor az MKP-val való együttmüködés szükségességét a pártvezetők képzettségével és megbízhatóságával indokolta. „A kommunista párt képviselői politikailag kifogástalanul képzettek, modorukban tartózkodóak, tárgyalásaikban soha nem túlzók, megállapodásaikban feltétlenül megbízhatók, a magyar érdekeket mindenkor figyelembe veszik, sőt lehet a magyar kommunista párttal együtt müködni. Most azonban nem csak lehet, hanem kell is." 294

Nem csoda ezek után, hogy Balogh - mint a kommunisták szövetségese ellenségeket is szerzett magának. Küldöttség kereste föl Hamvas Endre csanádi püspököt, hogy tiltsa el Balogh pátert a közéleti szerepléstől. A püspök azonban ezt elutasította. ${ }^{295}$ Később megváltozott Baloghnak a kommunistákról alkotott véleménye és a kommunisták sem föltétlen szövetségesként tekintettek a páterre.

Az 1944. december 3-i szegedi nagygyülésen a Független Kisgazdapárt nevében szólalt föl. A nemzeti újjászületés demokratikus programja nagy lelkesedést váltott ki. A szegedi városi színház zsúfolásig megtelt - tudósított a Délmagyarország. A gyülés első részében ismertették a Magyar Nemzeti Függetlenségi Front programját, majd Pálffy György föispán tartott megnyitó beszédet. Töle vette át a szót Balogh. Először a kisgazdapárt sérelmeit ismertette: a pártot föloszlatták, lapját megszüntették, vezető tagjait internálták. Föladatként jelölte meg a németek teljes leverését és új élet

\footnotetext{
${ }^{293}$ Délmagyarország, 1944. december 1.

${ }^{294}$ Délmagyarország, 1944. december 3.

${ }^{295}$ Balázs György, 1984. 236.
} 
fakasztását a pusztulás nyomán. A kommunista párt védelmére kelt beszédének következő részében. Kifejtette, hogy a pártot szerinte úgy festették le, hogy az a német külpolitikai érdekeknek megfelelő legyen. A német imperialista törekvések aggályossá tették a kommunista párttal való együttmüködést. De világossá vált, hogy a párt a polgári társadalom tagjait, a vallásszabadságot és a magántulajdont tiszteletben tartja vélte Balogh. Mivel szerinte a MKP a magyarság érdekeit képviseli, a politikus pap álláspontja az volt, hogy a kommunistákkal készségesen együtt kell müködni a demokratikus magyar élet újjáépítéséért. Az, hogy az öt párt közös nevezőre jutott, egyedülálló a magyar politikában. Beszédét a következő szavakkal zárta: „Jöjjön a demokratikus Magyarország magyar életének kiteljesedése."296

Utána Erdei Ferenc (NPP), Révai József (MKP), Örley Zoltán a Polgári Demokrata Párt nevében, majd Valentiny Ágoston (SZDP) és végül Komócsin Mihály a szabad szakszervezetek képviseletében jutottak szóhoz. ${ }^{297}$ A nagygyülés tehát kimondta a Magyar Nemzeti Függetlenségi Front megalakulását és elfogadta annak programját. Ezek egyike a németekkel való teljes szakítás, a Nagy-Magyarország iránti törekvések lezárása, a Szovjetunió elleni harc befejezése, és jószomszédi viszony kialakítása a környező államokkal.

Balogh páter decemberben e programponttal kapcsolatban is tett közzé írást a Délmagyarországban Perspektívák címmel. Szerinte önálló magyar külpolitika II. Ulászló óta nincs. Magyarország mindig az osztrák és a német érdekeknek vetette alá magát. Egy rövid ideig tartó, öncélú külpolitikai kezdeményezése volt Horthy 1926-os beszéde, amely baráti gesztust jelentett Jugoszlávia felé. De Gömbös már a németek felé orientálódott, így a külpolitikai függetlenség csak tíz évig tartott. ${ }^{298}$

A cikk szerint mindig a németektől reméltük Trianon revízióját, de ők, miután minden szomszédunkkal ellenséges viszonyt alakítottunk ki, még a Szovjetunió elleni háborúba is belekényszerítették az magyar államot. Ez - írta Balogh - a magyar külpolitika teljes elkorcsosulásának időszaka volt. Hogy ne váljunk a nagyhatalmak sakkfiguráivá, vélte megtalálni a kiutat Balogh, a Szovjetunió felé kell orientálódni egyrészt azért, mert nem akar bántani függetlenségünkben, magyarságunkban; másrészt mert döntő szava lesz a nagyhatalmak tanácsában és a vele való politikai kapcsolat

\footnotetext{
${ }^{296}$ Délmagyarország, 1944. december 5.

${ }^{297}$ Délmagyarország, 1944. december 5.

${ }^{298}$ Délmagyarország, 1944. december 10.
} 
megerősítheti nemzetközi helyzetünket; harmadrészt pedig, mert a tudományos, mủvészeti, gazdasági és kereskedelmi kapcsolatok nagy perspektívákat tárnak elénk. ${ }^{299}$

1944. december 14-én Debrecenben tartotta meg alakuló ülését az Ideiglenes Nemzetgyülés Előkészítő Bizottsága, amelynek elnöke Vásáry István kisgazda politikus volt, és tagjai között szerepelt Balogh páter is. A bizottság 1944. december 15. és 20. között - közel ötven helységben - bonyolította le a képviselődelegáló gyüléseket. Közvetlenül, nyílt szavazással döntöttek a megjelentek a képviselök személyéről a nemzeti bizottságok közremüködésével. Nem választott, hanem delegált tagokból állt az ideiglenes törvényhozás.

A Délmagyarország 1944. december 19-i keddi száma tudósított a szombati eseményről, a nemzetgyülés szegedi küldötteinek megválasztásáról. Reggel adták hírül, hogy délután 3-kor népgyülés lesz a Belvárosi moziban. A szegedi nemzeti bizottság elnökével, Baloghgal az élén vonult be a moziba, ahol nagy taps után megnyitó beszédbe kezdett. Először a németekről a következőket mondta: „Amint összeomlott az ő hadseregük, úgy foszlott szerte hamis propagandájuk hazug vára is.” Magyarország a németek kiűzésének megkezdése óta sokat haladt elöre a függetlenség felé. Az út vége egy független, demokratikus, népi Magyarország. De egyelőre nincs államfő, nincs központi kormány és nincs jogfolytonosság. Az ősforrás maga a nemzet, a magyar nép, aminek Ideiglenes Nemzetgyülést kell választania.

A város által kiküldendők névsorát (köztük Baloghot) Örley Zoltán olvasta föl. A népgyülés lelkesen ünnepelte és Szeged követének választotta Rákosi Mátyást. Ekkor újra Balogh szólalt föl: „Szeged népe egyhangú lelkesedéssel küldi ki az ideiglenes nemzetgyülésbe a most felolvasottakat, akik között minden dolgozó réteg képviseletre talál.",300

A másnapi szám tudósított arról, hogy Szeged népének választottjai elindultak az Ideiglenes Nemzetgyülésbe. Mivel Balogh is köztük volt, Szegeddel való kapcsolata ekkortól lazulni kezdett. Az első ülést 1944. december 21-én tartották. Ekkor az Ideiglenes Nemzetgyülés elnökséget és - rendszeresen és gyakran ülésező - Politikai Bizottságot választott, amelynek titkára Balogh István lett, s így részt vett az Ideiglenes Nemzetgyülés Szózata Révai József által írt szövegnek az előkészítésében is, ${ }^{301}$ sőt ő

\footnotetext{
${ }^{299}$ Délmagyarország, 1944. december 10.

${ }^{300}$ Délmagyarország, 1944. december 19.

${ }^{301}$ Balázs György,1984. 236.
} 
ismertette a magyar néphez intézett szavakat, amely után a hallgatóság hosszasan ünnepelte öt.

A Délmagyarország 1945. január 6-i tudósítása adott hírt róla, hogy a nemzetgyülés kormány alakításával 1944. december 22-én dálnoki Miklós Bélát bízta meg, aki elö is terjesztette a kormánylistát. Balogh István pedig határozati javaslatban indítványozta, hogy a nemzetgyülés nyilvánítsa ki a kormánnyal szembeni bizalmát és adja meg számára az ország ügyeinek vezetésére vonatkozó fölhatalmazást. ${ }^{302}$

A Magyar Nemzeti Függetlenségi Front egyik pontjának értelmében Magyarországnak hadat kellett üzennie a hitleri Németországnak. Ez az ország legsürgetőbb feladatai közé tartozott. 1944. december 28-án került rá sor. Magyarország csatlakozása az antifasiszta hatalmakhoz így véglegessé vált, és megnyílt az út a fegyverszüneti egyezmény megkötéséhez is.

Ezen a napon jelent meg a Délmagyarországban Balogh páter írása Magyar béke címmel. E béke ára - az államtitkár szerint - a jóindulat és a kölcsönös bizalom a Szovjetunióval. A németek mesterkedéseinek eredményeként rossz szomszédok lettünk. Ők a pánszlávizmus veszedelmét hirdették, de sokkal fontosabb a szomszédokkal való jó viszony - hangoztatta már nem először. Magyarország számára az igazi békét nem az jelenti, hogy más népeket szorít határaik mögé, hanem az, hogy ha saját függetlenségét, őshitét, hagyományait biztosíthatja. ${ }^{303}$

1944. december 28-án indult Moszkvába a magyar küldöttség. Az utazásról és a moszkvai fegyverszüneti tárgyalásokról 1945. február 4-én számolt be Szegeden Balogh államtitkár, amelyről a Délmagyarország is tudósított. Beszédében először azt hangoztatta, hogy az Ideiglenes Nemzeti Kormány szakított a bünös múlttal, Németországnak hadat üzent, a szövetségesektől fegyverszünetet kért és kedvező választ kapott. Rákosi Mátyással ekkor ismerkedett meg személyesen a politikus. Nagy tisztelettel beszélt Rákosiról, akinek mint Szeged képviselőjének átadta mandátumát. „Megható volt az az aggodalom és féltés, amellyel hazájáról, a magyarság jövendő sorsáról beszélt" - emlékezett vissza szinte elérzékenyült patetikussággal Rákosira a páter. $^{304}$

A fegyverszüneti megállapodás 1945. január 20-i aláírása után a magyar delegáció emigráns kommunistákkal - köztük Rákosi Mátyással - együtt indul haza.

\footnotetext{
302 Délmagyarország, 1945. január 6.

303 Délmagyarország, 1944. december 28.

${ }^{304}$ Délmagyarország, 1945 . február 6.
} 
Rákosi visszaemlékezéseiben így írt erről: „Balogh egyre nehezebben bírja az utat, mert hájtömegének csak egyik fele fér el a hálókocsi ágyán, s emiatt rosszul alszik. Kissé vegyes gondolatokkal nézem, amint szorgalmasan forgatja az olvasóját, $\mathrm{s}$ a nap minden szakaszában elmormolja a megfelelő imát. Úgy a külseje nem nagyon mutat vallásos emberre, inkább olyanra, aki sem a hús, sem a gyomor örömeit nem vet meg, s nemsokára hallom is töle a magyarázatot, hogy az egyház papjaitól csak cölibátust követel meg, nőtlenséget, de nem nemi megtartóztatást."305

1945. március 15-én Szegeden, a Klauzál téren tartott ünnepi beszédében Balogh többek között hangoztatta, hogy nagyon fontos, hogy a föld azok kezébe kerüljön, akik megmüvelik, de - és ezzel csak a fönnálló helyzetet ismertette - nem adhatnak több földet, mint amennyi van. Emlékeztetett arra, hogy tizenkét évig tanyán élt és látott már csodákat, ahol a munkabírás és a föld szeretete fütötte Szeged-Alsótanya népét. „A munkán kívül - mondta Balogh - még az Úristen segítsége és áldása szükséges ahhoz, hogy a föld kenyeret adjon.”,306

Nyilatkozata a kormány legsürgősebb, legfontosabb programpontjáról a földreform-tervezetről a szegedi újság 1945. március 18-i számában jelent meg. Balogh itt elmondta, hogy az akkor készülő kormányrendeletek arra irányulnak, hogy megszilárdítsák az új magyar demokráciát és védelmet nyújtsanak a fasizmus ellen. Az elkészült földbirtokreform-tervezet pártközi tárgyalásairól csak azért jött el Debrecenből, mert szeretett városáról, Szegedről volt szó. A tervezet a minisztertanács ülésén kormányrendeletté emelkedhet - vélte Balogh. A demokratikus pártok mindenképpen a tavaszi munkák elején kívánták megvalósítani a földreformot. ${ }^{307}$

Az 1945. március 15-i ünnepségeken Délmagyarország szerint negyvenezer fös tömeg ünnepelte a Balogh pátert és Rákosi Mátyást. Balogh tartotta a megnyitó beszédet, amelyben hangoztatta örömét, hogy a Szegedi Nemzeti Bizottság - amelynek ekkor még elnöke volt - első ízben rendezhette meg a szabad március 15-i ünnepséget. Arra is figyelmeztetett, hogy hálásak lehetnek a szegediek, hogy Rákosi Mátyás az egyik ünnepi szónok, aki szerinte egy életen át a magyar szabadságért küzdött. Zárszóként Balogh István a Vörös Hadsereg és Szovjetunió erényeiröl beszélt: 1848-ban olyan országból jött a segítség az osztrákoknak, ahol önkény és imperializmus, valamint egy erőszakos hadsereg volt. „Most ott a szabadság él! Nincs eltiprás, erőszak. A

\footnotetext{
${ }^{305}$ Rákosi Mátyás, 1997. 144.

${ }^{306}$ Délmagyarország, 1945. február 20.

${ }^{307}$ Délmagyarország, 1945. március 18.
} 
felszabadítást hozza magával a szabadság hadserege, a Vörös Hadsereg” - mondta Balogh. ${ }^{308}$

Ebben az időszakban azonban már egyre kevesebb írása, beszéde jelent meg a politikusnak a Délmagyarországban. Egy-két látogatásáról tett ugyan említést a lap, de korántsem olyan alapossággal és részletesen, mint korábban.

1945 júniusában Tildy Zoltánt Szeged díszpolgárává avatták. Balogh páter ezen az eseményen és a kisgazdapárt szegedi nagygyülésén is megjelent és kérte, hogy a helyi polgárság is vállaljon szerepet az ország újjáépítésének munkájából. A kétségtelenül jó politikai érzékkel - és persze jó kapcsolatokkal és információkkal rendelkező Balogh fölismerve a koalíción belül bomlásnak induló egyetértést, sietett elejét venni az ellentétek kiéleződésének. 1945. június 29-i szegedi beszédében fölelevenítette a „szegedi kézfogást”, az 1944-es indulást, amikor még összhang volt a pártok között és fölszólította az értelmiségieket is, hogy vegyék ki a részüket a demokrácia építésében. Az államtitkár ekkor részt vett a városi közgyülés első ülésén is, ahol arra kérték a politikust, hogy a kormány intézményesen is gondoskodjon a deportálásból hazatértek kártalanításáról. Balogh megnyugtatta őket azzal, hogy már történt ilyen intézkedés, de megígérte a további segítséget is. ${ }^{309}$

Érzékelhető tehát Balogh István - ugyan változó súlyú, de - bizonyosan nagy politikai befolyása. A kommunisták előretörésének - a Rákosi-klikk hatalomra jutásának - időszaka volt az 1944 és 1948 közötti periódus. Ezt részben a nagykoalíciónak köszönhették, amikor a kisgazdapárt és a Magyar Kommunista Párt kénytelen volt együtt kormányozni. De 1946-tól már fölmerültek a problémák: a koalíció válsága - kommunista(barát) mozgósítás a kisgazdapárt és szociáldemokraták jobbszárnya ellen - és a kommunista párt - szovjet támogatással bekövetkezett politikai térnyerése figyelhető meg. Hangsúlyozott a politikai térnyerés, hiszen a rendőrség, a helyi közigazgatás és az állami gazdaságirányítás főbb pozícióiban már az újraindulás kezdetétől kommunisták ültek. Ezzel együtt változott Balogh megítélése is, $\mathrm{s}$ ezt a - páternek hol ellenséges, hol szövetséges szerepet osztó - tendenciát követte a kommunista lap, a Délmagyarország is.

Ekkor már megjelentek a lapban Balogh-ellenes támadások. Mint a fejezet korábbi részében láthattuk - államtitkárként ő irányította a sajtóügyeket és a

\footnotetext{
${ }^{308}$ Délmagyarország, 1945. március 17.

${ }^{309}$ Délmagyarország, 1945. július 1.
} 
papírkészletek elosztását. A Délmagyarország ennek kapcsán megjelent cikke szerint fölháborodást váltott ki a kommunisták körében, hogy központi lapjuk, a Szabad Nép számára sem jutott elég papír. Ugyanekkor írt a szociáldemokrata Népszava, hogy a Baloghhoz köthető - Magyar Nemzet és Mai nap nyomdájában garmadával álltak a lapok. A később demagógiájáról elhíresült Marosán György - aki akkor szociáldemokrata baloldalt képviselte - úgy vélte, az államtitkár nem akarta, hogy a munkáspártok és a polgárság lapjai megjelenjenek. A miniszterelnökségi sajtóosztály szerinte a páter utasítására „szabotál papírfronton”. 310

Végül kommunista nyomásra Balogh páter hatáskörét a papírelosztás ügyében Kállai Gyula miniszterelnökségi államtitkár vette át. „Így a reakció teljes vereséget szenvedett papírfronton" - írta az ekkor már kommunista Délmagyarország. A Szovjetunió azzal a gesztussal kapcsolódott be a vitába, hogy nagy mennyiségü rotációs papírt küldött az országba. A kommunisták természetesen hálásak voltak: „A Szovjetuniónak ez a nemes gesztusa újabb bizonyítéka annak, hogy a népi demokráciáért tartott küzdelemben számíthatunk nagy szomszédunk támogatására."311

A választások közeledtével a nagykoalíció megingani látszott. Az Ideiglenes Nemzetgyülés szeptemberi ülésszakán 1945. november 4-ére tüzték ki a nemzetgyülési választások időpontját. 1945 szeptemberében és októberében a pártok már a választásokra készülődtek. Külön választási programot csak az MKP adott ki, de választási fölhívások, röplapok, plakátok árasztották el az egész országot. Igen jelentős szerepet játszottak a választási küzdelemben a választási gyülések, a személyes agitációk és egymás lejáratása is. A munkáspártok nagy ellenfele a kisgazdapárt volt.

Balogh ellen is jelentek meg lejárató hangvételü írások a Délmagyarország hasábjain. 1945 októberében Kisgazdagyülés a színházban, avagy színház a kisgazdagyülésen címmel írtak FKGP-ellenes cikket. A kommunista lap szerint a szónokok virágnyelven beszélve rejtett célzásokkal burkolt reakciós propagandát fejtettek ki. Amikor pedig Balogh a fölszabadulásról és a dicsőséges Vörös Hadseregről beszélt, a közönség soraiból gúnyos kacagás hallatszott és sokatjelentő, sunyi összenézések voltak láthatóak. „Balogh István minden látható szégyenkezés nélkül merte azt állítani, hogy a nyilasok és a reakciósok nem a kisgazdapártban vannak,

\footnotetext{
${ }^{310}$ Délmagyarország, 1945. július 22.

${ }^{311}$ Délmagyarország, 1945. július 24.
} 
hanem [...] a munkáspártokban! (Úgy látszik, az államtitkár úr nem figyelte eléggé a gyülés lefolyását!)”312 - írta a Délmagyarország.

Egy másik cikk kifejezetten Balogh személye ellen szólt. Látható, hogy néhány hónap alatt az ünnepelt államtitkárból ellenséget igyekezett kreálni a kommunistává vált lap. Megemlítették Balogh egy évvel azelőtti nyilatkozatát, amelyben azt mondta, hogy „a Kommunista Párt most első ízben lép egyenrangú félként a magyar politikai élet porondjára". Addig a német politikai életnek megfelelően a magyar népben gyülölet támadt a kommunizmus szó hallatára. Ezt kívánta Balogh akkor eloszlatni. Az a kommunizmus ugyanis a polgári társadalom jogait tiszteletben tartja, a teljes vallásszabadság és a magántulajdon védelmét hirdeti. Erre a nyilatkozatra reagált Révai József októberben a Délmagyarországban: „Ma más divat járja. Ha Balogh István ma elmondaná ugyanezeket a szavakat, akkor attól tartok, hogy saját kisgazda elvbarátai közül akadnának olyanok jónéhányan, akik megköveznék érte. Pedig hát, ami igaz volt egy évvel ezelőtt, az igaz ma is." 313

Meg kell azonban jegyeznünk, hogy az államtitkár tevékenysége korántsem ilyen egyértelmü. A választások előtt azt az álláspontot támogatta, hogy a baloldali pártokkal előre állapodjanak meg a koalíciós kormányzás folytatásában, a tárcák elosztásában. Támogatta a közös lista tervét is, amely a Kisgazdapártnak 47,5\%-ot juttatott volna. Ez azonban ellenállást váltott ki a párt köreiben és végül angolszász tiltakozásra lekerült napirendről, így a mandátumok elosztásáról a választók dönthettek. Balogh már az országos politika életbe való bekapcsolódásakor is a nagykoalíció gondolatát tartotta irányadónak, s nyíltan a két párt között kapocs akart lenni: a kisgazdákkal és a kommunistákkal is meg akarta értetni magát.

Egy darabig maguk a kommunisták is hasznosnak találták Balogh tevékenységét. A korabeli lapszámokban publikált cikkekből kiolvasható, hogy együttmüködtek vele, még ha nem is bíztak benne teljesen. Révai még 1945 januárjában Rákosinak azt írta, hogy a páter a balszárnyhoz tartozik. Rákosi is rendszeresen egyeztetett vele vitás kérdésekben, végig jó kapcsolatban maradtak egymással. ${ }^{314} \mathrm{~A}$ politikus a kisgazdapárt vezetéséhez is kis távolságtartással közeledett, bár később - a kommunistákkal való egyeztetés után - részt vállalt Nagy Ferenc miniszterelnök lemondatásában. A koalíciót mindig védelmébe vette. A Magyar Nemzet hasábjain is

\footnotetext{
${ }^{312}$ Délmagyarország, 1945. október 16.

${ }^{313}$ Délmagyarország, 1945. október 30.

${ }^{314}$ Klettner Csilla, 2004. 105-107.
} 
azt éltette, de elutasította a kommunisták erőszakos túlkapásait. Írásaiból az is kitűnt, hogy jobboldalellenes, szovjetbarát politikát folytatott, de a háttérben kereste a kommunista nyomás alóli kibontakozás útjait. Egyes paptársai szerint pedig kifejezetten kommunistabarát politikus volt. Kétségtelen - és ezt egyik levelében ő maga is elismerte -, hogy a kommunisták a fekete reakcióhoz tartozó papot, a kisgazdák a kommunistabarát politikust látták benne. ${ }^{315}$ Ennek ellenére, vagy éppen ezt belátva Balogh István úgy igyekezett lavírozni az 1940-es évek politikai életének viharos vizein, hogy mindig száraz maradjon. Ennek köszönhetően 1944 végétől 1951-ig a szüken vett állami vezetés - és hatalom - részese tudott maradni.

1946 januárjában, amikor Pálffy György föispáni beiktatására került sor, Balogh is megjelent Szegeden és mint a Független Kisgazda-, Földmunkás és Polgári Párt képviselője nyilatkozott a Szegedi Hírlapnak. Az interjú azonban nem ott jelent meg, hanem a Délmagyarországban.

Balogh elmondta, hogy az Független Kisgazdapárt központi és vidéki szervezkedése most veszi kezdetét. A helyi elnökökre és a választmányokra nagy munka vár és nagy felelősség hárul rájuk. Mivel a nemzetgyülésben a képviselők komoly tevékenységet folytatnak, ami ráadásul Budapesthez is köti őket, az FKGP határozatot hozott, miszerint a nemzetgyülési képviselők nem vállalhatnak fontos szerepeket, például vidéki szervezetek elnökségét, mert mindkettő egész ember munkáját igényli. És mivel - ahogy a lap írta - a kisgazdapárt központi vezetősége eltávolítja a pártközi együttmüködést akadályozó elemeket (Nagyiván János, Shovy Kálmán, Hunya Benedek) a szegedi vezetőségből, az MKP, a szegedi demokratikus pártok és az FKGP együttműködése harmonikus és eredményes lesz. ${ }^{316}$

A Délmagyarország a későbbiekben is foglalkozott azzal a kérdéssel, hogy a Szegedi Hírlap miért nem közölte Balogh ezen nyilatkozatát. A lapot a kommunisták Nagyiván János „önreklám közlönyének” tartották, amely szerintük a fasiszta zavarkeltési technika színvonalán áll. ${ }^{317}$ Lapjában Nagyiván hazaáruló magatartását igyekszik mentegetni - vélte a Délmagyarország újságírója - és ő maga is szeretné megmagyarázni, s a szegedi kisgazdák Nagyiván-klikkje szembehelyezkedett Tildy Zoltánnal és Baloghgal.

\footnotetext{
315 SZCSPL PHEI 1333/1945.

${ }^{316}$ Délmagyarország, 1946. január 6.

${ }^{317}$ Vö. Tamasi Mihály: A szegedi gazdapolitikus, Nagyiván János. 1893-1961. Szeged, 2009. 48-76.
} 
A Szegedi Hirlap kétségbe vonta Balogh nyilatkozatának hitelességét és szerinte az államtitkár nem beszélt egyetlen helyi kisgazda vezetővel sem arról a határozatról, amely a vidéki szervezetek elnökeit eltiltotta a nemzetgyülési képviselőségtől. Ezt a kommunisták azzal cáfolták, hogy ha Balogh azt mondta, hogy ezt Szegeden is végre kell hajtani, akkor erről tudnia kellett Pálffy főispánnak és Tildynek is.

Nagyiván azzal az ,átlátszó indokkal” támasztotta alá - írt a Délmagyarország , hogy megtagadta a nyilatkozat Szegedi Hirlapban való megjelenését, hogy a hír már lapzárta után érkezett. Ez a Délmagyarország szerint azért képtelenség, mert a nyilatkozat szombaton készült, a kisgazda hetilap szerkesztése pedig hétfön, megjelenése pénteken történik. Végül kommunista nyomásra Nagyivánék beismerték, hogy a nyilatkozat közlése nem állt szándékukban és ezért jelent meg a Délmagyarországban - Balogh fölhatalmazásával.

A kommunisták szerint azért is volt irreális a feltételezés, hogy Balogh nem ismerte a szegedi kisgazda pártszervezet elnöki tanácsának hangulatát, mert éppen maga a szegedi kisgazdapárt küldöttsége fordult memorandumban a párt országos vezetéséhez és kérte föl Baloghot arra, hogy szabadítsa meg a pártot a „Shovy-Nagyiván-klikk diktatúrájától. $^{318}$

Balogh 1946-ban kisgazdapárt országos válságának megoldásán fáradozott, bár az egység zálogát a jobboldaliak kizárásában vagy meggyöngítésében, ezzel pedig az 1946 márciusában megalakult Baloldali Blokk jelszavát - Ki a nép ellenségeivel a koalícióból! - képviselte. Elnökölt Szegeden a szegedi FKGP-szervezet 1946. március 14-i ülésén, ahol több kisgazda képviselöt is kizártak, és - ezek után egyáltalán nem meglepő módon - elismeréssel beszélt a munkáspártok tevékenységéről is 1946. március 15-i szegedi beszédében. Elmondta, hogy a Független Kisgazdapárt jobbszárnya és Mindszenty József politikai tevékenysége ellen tüntetők „példamutatóan” viselkedtek demonstrációjuk során. „Mindaz, ami Budapesten történt, becsületére válik a munkáspártok vezetőinek és tagjainak" - fogalmazott Balogh az ünnepségen. ${ }^{319}$

1946. január 26-án a Délmagyarország tényként állította, hogy Tildy Zoltán lesz a Magyar Köztársaság elnöke. Az államfő megválasztása után a lap szerint Nagy Ferenc

\footnotetext{
318 Délmagyarország, 1946. január 29.

${ }^{319}$ Délmagyarország, 1946. március 17.
} 
vagy Balogh István neve merülhet föl, mint a következő miniszterelnöké. A kisgazdapártban Nagy Ferenc esélyét ítélték jobbnak. ${ }^{320}$

Miután a köztársasági elnököt, Tildy Zoltánt a parlament megválasztotta, a nemzetgyülés 1946. február 4-i ülésén Nagy Ferencet választották miniszterelnöknek, a nemzetgyülés elnöke pedig a római katolikus lelkész Varga Béla lett. Nagy Ferenc javaslatára az új kormány február 4-i első ülésén úgy határozott, hogy „hozzájárul ahhoz, hogy a miniszterelnök a köztársasági elnöknél Balogh István miniszterelnökségi államtitkár újbóli kinevezését hozza javaslatba" - tudósított a Délmagyarország. ${ }^{321}$

1946 augusztusában nyílt támadás jelent meg Balogh ellen Méregkeverés címmel a lap hasábjain. A kommunisták központi lapja, a Szabad Nép cikke alapján közölte a Délmagyarország, hogy a budapesti Kis Újságban - a kisgazdapárt lapjában provokatív és rágalmazó közlemény látott napvilágot. Ebben - a Szabad Nép szerint Rákosi Mátyás beszédéből kiragadott idézettel akarták bizonyítani, hogy egy miskolci lincselésért (amit állítólag internált nyilasok hozzátartozói szítottak), ő a felelős. Pedig a kommunisták szerint Rákosi a rendelet szerint cselekedett, mikor a spekulánsok számára halálbüntetést rótt ki, ami a zavargást okozta Miskolcon.

A cikk írója azt állította, hogy nem Dessewffy Gyula, a Kis Újság szerkesztője állt a közlemény mögött, hanem Balogh István, ,,a kisgazdapárt legfőbb sajtóirányítója”. „És aztán már nem csodálkoztunk. Az államtitkár úrról már régen tudjuk, hogy specializálta magát a méregkeverésben” - írta a szegedi hírlap. A lap szerint a páter a nyilvános fórumokon, mint ,a válságok örök elsimítója” szerepel, a valóságban nem az, s valójában saját maga számára egyengeti az utat. Mind a jobboldal, mind a baloldal jelöltjeként föltünteti magát - hangzott ellene a nem kis igazságtartalommal bíró vád. „Az bizonyos, hogy mi kommunisták, ezzel a rágalmazó úrral többé nem ülünk le egy asztalhoz" - fogalmazott Délmagyarország szerzője. ${ }^{322}$

Egy másik, Balogh elleni rágalom nem közvetlenül a személyével kapcsolatos. A kommunista lap azt állította, hogy Berey Géza csak azért lépett be a Magyar Kommunista Pártba, hogy visszaszerezze a Délmagyarországot s minthogy ez nem sikerült neki, kilépett a pártból és a kisgazda Szegedi Kis Újsághoz szerződött. De mit akarhat elérni a kisgazdapárton keresztül? - tette föl a kérdést a szegedi kommunista

\footnotetext{
${ }^{320}$ Délmagyarország, 1946. január 26.

${ }^{321}$ Délmagyarország, 1946. február 5.

${ }^{322}$ Délmagyarország, 1946. augusztus 7.
} 
újság. ,...esetleg főispánságot vagy polgármesterséget ígért neki legfőbb patrónusa, a feddhetetlen Balogh atya, akit Budapesten páter »Zabravecz« néven ismernek?"323

Erre már a Szegedi Kis Újság is reagált: védelmébe vette Baloghot, „amiért a Kisgazdapárt Leóját bántani merészelték" - tette hozzá a Délmagyarország. A kommunisták gúnyosan arról a Balogh páterről beszéltek, ,aki iránt Szegeden éppúgy, mint a Fidzsi-szigeteken, fuldokló tisztelet és szünni nem akaró rajongás nyilvánul meg”. Támadás érte Balogh anyagi helyzetét is: a Szegedi Kis Újság azt írta, hogy a kisgazdapártiak kamrái üresek maradnak akkor is, ha belépnek az MKP-be.

A Délmagyarország a cikket a „nagy Főnök kövér zsenijének körülnyaldosásának” tartotta és azt írta, hogy „gyorsan vizsgáljuk meg például Balogh páter és a többi lakkcipős kisgazdavezér, valamint a kommunista vezetők kamráit és a mutatkozó különbözetet osszuk szét”. „A szegedi kommunisták nem türik, hogy a méregkeverés páteri módszerei a városban is meghonosodjanak" - írta a Délmagyarország. ${ }^{324}$

Mindezen kommunista hírlapi támadások ellenére Balogh végig a koalíció mellett foglalt állást a kormányválságok idején.

\section{3. A földbirtokreformmal kapcsolatos ügyek előadója ${ }^{325}$}

Balogh az Ideiglenes Nemzetgyülés Politikai Bizottságának előadójaként vizsgálta és terjesztette elő a testületnek azon igénylők ügyét, akik birtokuknak a fölbirtokreformban való igénybevétele alól szerettek volna mentesülni.

A földreform szükségességéről a koalíciós pártok között nem volt vita. Annak végrehajtásával kapcsolatban azonban már voltak nézeteltérések. A leginkább életképes koncepciót a Független Kisgazdapárt dolgozta ki hosszútávon is fönntartható és

\footnotetext{
${ }^{323}$ Délmagyarország, 1946. augusztus 9.

${ }^{324}$ Délmagyarország, 1946. szeptember 6.

${ }^{325}$ Az itt közöltek korábban megjelent változata: Miklós Péter: Balogh István és a földreform. Acta Universitatis Scientarium Szegediensis. Acta Historica. Tomus CXXXIII. Szerk. Marjanucz László. Szeged, 2011. 51-60.
} 
fönnmaradó (családi) magántulajdonú paraszti birtokrendszert vizionálva. ${ }^{326}$ Végül azonban az alapjaiban a Nemzeti Parasztpárt benyújtotta, aztán a kommunisták által is támogatott javaslat került elfogadásra. Ez ugyanis beleillett a Magyar Kommunista Párt akkori agrárstratégiájába: egyrészt rövid távon politikai népszerüségnövekedést hozott az agrárnépesség körében, másrészt jobbára életképtelen kis- és törpebirtokrendszert alakított ki, amelyböl (megfelelő eszközök és technológia híján) - remélték joggal a kommunisták - hamar a szövetkezetekbe lép majd az újonnan fölhöz jutott parasztság.

Az Ideiglenes Nemzeti Kormány 1945 márciusában kiadott 600/1945. M.E. számú rendeletével - amelyet az Ideiglenes Nemzetgyülés az 1945. évi VI. törvény becikkelyezésével kodifikált - határozott a földosztásról. Prioritásként a napszámosok, mezőgazdasági cselédek, nagycsaládos szegényparasztok és törpebirtokosok földhöz juttatását jelölte meg. Országszerte mintegy 3200 földigénylő, illetve földosztó bizottság müködött, közel 35000 taggal. Munkájukat a Veres Péter elnökletével megalakult Országos Földbirtokrendező Tanács koordinálta.

A földreformrendelet végrehajtását elsősorban a kereskedelmi és banktőke birtokainak, az 1000 katasztrális hold fölötti nagybirtokoknak, s a nyilas, szélsőjobboldali vezetők és háborús bűnösök földjeinek a terhére képzelték el. De az 1000 hold alatti birtokból is vettek el: az úri birtok 100 holdig, a paraszti birtok 200 holdig maradhatott tulajdonosánál, de ha tudta igazolni antifasiszta és ellenálló tevékenyégét, akkor 300 hold földet is megtarthatott. ${ }^{327}$ A fölreform során 3,2 millió hold földet osztottak szét 642000 igénylö között. Ezzel a föld nélküli és az egy hold alatti földdel rendelkező agrárnépesség aránya 17\%-ra csökkent (az 1941-es 46\%-ról).

A nagybirtokrendszer megszüntetéséröl és a földmíves nép földhöz juttatásáról szóló kormányrendelet tizenötödik paragrafusa szerint: „300 kat[asztrális]. holdig mentesül az igénybevétel alól annak az ingatlana, aki a nemzeti ellenállásban és a németellenes szabadságharcban kimagasló érdemeket szerzett. Ennek megállapítása a Nemzetgyülés politikai bizottságának feladata.”

Mivel az Ideiglenes Nemzetgyülés csak néhány napot ülésezett (1944 decemberében Debrecenben és 1945 szeptemberében Budapesten), a gyakorlati

\footnotetext{
${ }^{326}$ Kovács Tamás: Egy elfelejtett földreformtervezet 1945-ből. Archivnet. XX. századi történeti források, 2008. 5. sz. - http://www.archivnet.hu/pp_hir_nyomtat.php?hir_id=132 (A letöltés időpontja: 2011. november 19.)

327 Vö. M. Somlyai Magda: Szabadulás és magvetés. Az 1945-ös földreform történetéből. Budapest, 1961. és M. Somlyai Magda: Földreform. 1945. Tanulmány és dokumentumgyüjtemény. Budapest, 1965.
} 
jogalkotó tevékenységet - mintegy „kis nemzetgyülésként” - az Ideiglenes Nemzetgyülés Politikai Bizottsága végezte. Huszonkét tagját a nemzetgyülési arányoknak megfelelően delegáltak a szervezetek: a Független Kisgazdapárt öt, az Magyar Kommunista Párt és a Szociáldemokrata Párt négy-négy, a Nemzeti Parasztpárt három, a Polgári Demokrata Párt kettő, a függetlenek öt tagot. Hozzájuk csatlakozott huszonharmadikként az Ideiglenes Nemzetgyülés Elnökségének képviselöje. A létszámánál fogva könnyebben és gyorsabban összehívható, kizárólag nemzetgyülési képviselőkből álló - Politikai Bizottság ellenőrizte a kormányt, a front nyugatra húzódásával intézkedett a nemzetgyülés kiegészítéséről és - 1945 májusa és szeptembere között - döntött az öt parlamenti bizottság (gazdasági, véderő, birtokpolitikai, alkotmányjogi, mentelmi) fölállításáról. ${ }^{328}$

Az Ideiglenes Nemzetgyülés Politikai Bizottsága 1945. március 12-én délután négy órakor tartott második ülésén tárgyalta a földreform ügyét. A kisgazda Balogh István jelezte: az előterjesztés szerint úgy tünik, hogy a földreform ügye „csak a bizottság kommunista tagjainak javaslata”, noha - mint emlékeztetett az államtitkár - a miniszterelnök is javasolta ugyanezt a kormány azon tagjainak, akik tagjai a Politikai

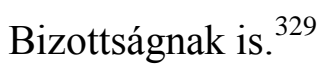

Révai József erre a Magyar Kommunista Párt nevében elmondta, hogy „nem akarja az elsőbbséget a kommunista párt részére elkönyvelni". ${ }^{330}$ Üdvözölte a miniszterelnök kérését, s kifejtette álláspontját, hogy a kérdést ne pusztán kormány-, illetve miniszterelnöki rendeletben, hanem törvényben szabályozzák, ezért javasolta az Ideiglenes Nemzetgyülés összehívását az 1945. március 20. és április 1. közötti időszakban. Erre reagálva a református püspök Révész Imre (pártonkívüli nemzetgyülési képviselő) és a katolikus pap Balogh István fölhívták a Politikai Bizottság figyelmét, hogy a Révai által említett periódus a keresztény húsvéti ünnepet megelőző nagyhétre esik. Révai ezt figyelembe vette és április első napjaira módosította a tervezett időpontot. Végül a Politikai Bizottság határozata azt javasolta az Ideiglenes Nemzetgyülés elnökségének, hogy 1945. április 1. és április 5. közé lehetőleg

\footnotetext{
${ }^{328}$ Miklós Péter: A koalíciós évek állama. 1944-1945. In: A magyar állam története. 1711-2006. Szerk. Szabó Pál Csaba. Szeged, 2010. 205-222.

329 Magyar Országos Levéltár. Ideiglenes Nemzetgyülés Politikai Bizottságának iratai. XVIII-5. (a továbbiakban: MOL XVIII-5.) Az 1945. március 12-i ülés jegyzökönyve. 9.

${ }^{330}$ MOL XVIII-5. Az 1945. március 12-i ülés jegyzőkönyve. 9.
} 
Budapestre hívja össze az Ideiglenes Nemzetgyűlést. ${ }^{331}$ (Erre azonban végül nem került sor.)

A Politikai Bizottság 1945. május 11-i harmadik ülésén Nagy Imre kommunista földművelésügyi miniszter javasolta, hogy a Politikai Bizottság hozzon létre egy albizottságot, amely ezeket az ügyeket vizsgálja, mivel ,sem a minisztérium, sem az országos földbirtokrendező tanács ebben a kérdésben a legjobb akarat mellett sem tud javaslatokat tenni a szóban lévő egyének politikai magatartásától, amelynek elbírálására, sem egyik, sem másik szerv nem hivatott és nem is képes". ${ }^{332}$ Balogh István - mint a téma előadója a bizottság részéről - ígéretet tett, hogy a létrehozandó albizottság a Politikai Bizottság következő ülésére előkészíti a beérkezett kérelmeket úgy, hogy „,azokat könnyű lesz elbírálni és könnyű lesz állást foglalni”. ${ }^{333}$

„Ellenállási érdemekre való hivatkozással - azt hiszem - minden nagybirtokos szeretne megtartani magának 300 holdat" - vélte a parasztpárti Kovács Imre. ${ }^{334}$ Ezért javasolta, hogy a Politikai Bizottság elé már csak azon személyek ügyei kerüljenek, akik bizonyíthatóan részt vettek az ellenállásban. A Politikai Bizottság végül döntött a földreformmal kapcsolatos kérelmek elbírálásának előkészítését végző albizottság létrehozásáról, amelynek tagjai a pártok delegáltjai. Az öttagú testület „a nemzetgyülés elnökének elnökletével és Balogh államtitkár úrnak, mint előadónak a bevonásával ezt az átrostálást elvégezné és megfelelő javaslatokkal lépne a politikai bizottság legközelebbi ülése elé", 335

Az Ideiglenes Nemzetgyülés Politikai Bizottsága 1945. június 1-jei negyedik ülésén a földbirtokreformmal kapcsolatos kérelmekkel foglalkozó albizottság már kész javaslatokkal állt elő. A kérelmek előadója Balogh István miniszterelnökségi államtitkár volt. Az alábbiakban néhány eset bemutatásán keresztül igyekszünk érzékeltetni a Politikai Bizottságnak a háromszáz holdas birtokmaximumot kérelmezőkhöz való viszonyulását.

Pokorny Miklós (1892-1946) kanonok, Győr-belvárosi apátplébános, győri káptalani helynök - amint Balogh István, az előadó fogalmazott - ,,a legutóbb tragikus körülmények között meghalt Apor Vilmos püspök érdemeire való tekintette kéri, hogy a

\footnotetext{
${ }^{331}$ MOL XVIII-5. Az 1945. március 12-i ülés jegyzőkönyve. 9.

${ }^{332}$ MOL XVIII-5. Az 1945. május 11-i ülés jegyzőkönyve. 30.

${ }^{333}$ MOL XVIII-5. Az 1945. május 11-i ülés jegyzőkönyve. 31.

${ }^{334}$ MOL XVIII-5. Az 1945. május 11-i ülés jegyzőkönyve. 32.

${ }^{335}$ MOL XVIII-5. Az 1945. május 11-i ülés jegyzőkönyve. 32.
} 
püspökség szanyi gazdaságából 300 kat[asztrális]. hold mentesíttessék az igénybevétel alól." 336 A kérelemben szerepelt, hogy Apor föllépett a nemzetiszocializmus és a fajelmélet ellen, s püspökként „fö feladatának tekintette e veszedelmes tanoknak az ifjúságtól való távoltartását”. ${ }^{337}$ Az albizottság azt javasolta a Politikai Bizottságnak, hogy az ügyet tekintse tárgytalannak, hiszen Apor Vilmos már nem él, így a győri egyházmegyei birtok már független az egykori püspök náciellenes tevékenységétől. A Politikai Bizottság így az ügyet nem tárgyalta.

Shvoy Lajos (1879-1968) székesfehérvári megyéspüspök szintén háromszáz katasztrális hold (Székesfehérvárott hét hold szőlő és öt hold gyümölcsös, Sárkeresztúron pedig kétszáznegyven hold szántó) föld fölbirtokreform alóli mentesítését kérte. Balogh páter ismertette, hogy Shvoyt a nyilas uralom alatt letartóztatták és rendőrhatósági őrizet alá helyezték, s hogy a főpap semmilyen módon nem volt hajlandó együttmüködni a nemzetiszocialistákkal. Az albizottság javaslatára a Politikai Bizottság helyt adott a székesfehérvári püspök kérelmének. ${ }^{338}$

Shvoy Lajos az 1960-as évek közepén írt önéletrajzában - utalva a földreformrendelet tizenötödik paragrafusára - a következőket írta: „Ez a kimagasló érdem $^{339}$ az volt, hogy Mindszenty - akkori veszprémi püspök - vezetésével egy memorandumot dolgoztunk ki az öcsém ${ }^{340}$ bevonásával, amelyben azt kértük, hogy a magyar hadsereg vonuljon vissza és védje a Dunántúlt és az ott összehajtott rengeteg állatot. A memorandumot magam vittem fel Szálasihoz, és leadtam sok nehézség után Szöllösi miniszterelnöknek ${ }^{341}$, aki elolvasván azt éktelen dühös lett."342

\footnotetext{
${ }^{336}$ MOL XVIII-5. Az 1945. június 1-jei ülés jegyzőkönyve. 26.

${ }^{337}$ MOL XVIII-5. Az 1945. június 1-jei ülés jegyzőkönyve. 27.

${ }^{338}$ MOL XVIII-5. Az 1945. június 1-jei ülés jegyzőkönyve. 28-27.

339 Vö. 600/1945. M.E. számú rendelet 15. paragrafus: „300 kat[asztrális]. holdig mentesül az igénybevétel alól annak az ingatlana, aki a nemzeti ellenállásban és a németellenes szabadságharcban kimagasló érdemeket szerzett."

340 Shvoy Kálmán (1881-1971) altábornagy, 1923-tól 1926-ig a Magyar Labdarúgó Szövetség elnöke, 1935 és 1939 között országgyülési képviselő. A koalíciós években a Független Kisgazdapárt szegedi szervezetében politizált (egy ideig a helyi elnökségnek is tagja volt).

${ }^{341}$ Helyesen: miniszterelnök-helyettesnek. Szöllősi Jenő (1893-1946) nyilas politikus. Makói patikus, 1939-től a város országgyülési képviselője. Szálasi Ferenc kormányában (1944. október-1945. március) tárca nélküli miniszter és miniszterelnök-helyettes.

${ }^{342}$ Shvoy Lajos: Önéletrajz. Szerk., bev., jegyz.: Mózessy Gergely. Székesfehérvár, 2002. 101.
} 
A külföldön tartózkodó Montenuovo Nándor herceg (1888-1951) nevében felesége nyújtott be kérelmet, hogy németbólyi birtoka mentesüljön a fölreform intézkedései alól. Mint az indoklásban szerepelt, Montenuovót a nyilas hatalomátvétel után a pécsi Mecsek Szállóban tartották őrizet alatt, később elengedték és kérték, hogy mint a felsőház tagja - vegyen részt a törvényhozás ülésén. Amikor ezt nem tette meg, letartóztatták és Sopronkőhidára hurcolták. Az albizottság úgy vélte - olvasható Balogh előterjesztésében -, hogy „ha bebizonyítást nyer, hogy ez megfelel a valóságnak, akkor sem üti meg azt a mértéket, amit kimagasló cselekménynek minősíthetünk". 343 A Politikai Bizottság elutasította a kérelmet. Az első világháborút végigharcoló - egykori huszártiszt - herceg hat évvel később márianosztrai fogolyként hunyt el.

Berczelly Jenő nyugalmazott igazságügyi államtitkár - akinek ezerötszáz holdas birtoka volt Bercel határában - arra hivatkozott, hogy gazdaságának készletét nem adta át a német haderőnek, ennek eredményeként aztán az teljes egészében a Vörös Hadsereg kezére kerülhetett. Az egykori államtitkár azt is előhozta, hogy ha földjeit fölosztotta volna felesége és három gyermeke között, akkor mindenki megtarthatott volna százszáz holdat, s így ötszáz hold maradhatott volna a család kezén, ezzel szemben a földreform után mindannyiuknak együtt legföljebb száz. Mivel az ellenálló tevékenységét nem tudta bizonyítani (vélhetően nem is fejtett ki ilyet), és érvelésének második része is abszurd volt, Beczelly kérését az albizottság javaslatára a Politikai Bizottság elutasította. ${ }^{344}$

Balogh István Mindszenty József veszprémi püspök kérelménél Schiberna Ferenc egykori Veszprém vármegyei nyilas főispánnak a főpapot rendőrhatósági őrizet alá vonó határozatából olvasott részleteket. ${ }^{345}$ Majd hozzátette: „Az albizottság e kérdésben nem tudott egyhangú álláspontot elfoglalni. Ezért azt a határozatot mondtuk ki, hogy nyitva hozzuk ide a kérdést és itt maga a politikai bizottság döntse el, hogy azok a cselekmények, amelyeket itt felolvastam ${ }^{346}$, amelyekkel a kormánybiztos

\footnotetext{
${ }^{343}$ MOL XVIII-5. Az 1945. június 1-jei ülés jegyzőkönyve. 29.

${ }^{344}$ MOL XVIII-5. Az 1945. június 1-jei ülés jegyzőkönyve. 61.

345 Vö. Balogh Margit: Mindszenty József veszprémi püspök nyilas fogságban. In: Újragondolt negyedszázad. Tanulmányok a Horthy-korszakról. Szerk. Miklós Péter. Szeged, 2010. 233-248.

346 Miszerint 1944. november 27-én Mindszenty a német katonai beszállásolást megakadályozta, „hatósági közeg elleni erőszakot követett el”, majd „tüntető felvonulás szervezésével a lakosság fellázítását kísérelte meg”. MOL XVIII-5. Az 1945. június 1-jei ülés jegyzőkönyve. 62.
} 
főispán ${ }^{347}$ őt vádolja, elegendők-e, ellenállásnak számítanak-e vagy sem.” ${ }^{\text {„34 }}$ A jegyzőkönyv szerint ekkor több „Igen!” fölkiáltás hangzott az ülésteremben.

Mindszenty bátor náciellenes tevékenységét elismerve az Ideiglenes Nemzetgyülés Politikai Bizottsága támogatta a püspök kérelmét. Rákosi Mátyás ekkor megkérdezte: „Nem lehetne-e kimondani, hogy ez az eset nem lehet precedens?”349 Tildy Zoltán ezt ellenezte, mivel: „két püspöki javadalmi földet hagytunk meg az ott szolgáló püspökök érdemeire való tekintettel. ${ }^{350}$ Nekem is van egy kis darabka földem és tisztelettel bejelentem, hogy lelkészi javadalmi földet hagyjanak meg számomra."351 Mindszenty egyébként emlékirataiban így fogalmazott a földreformról: „A földreformmal kihúzták az egyházi intézmények alól az anyagi alapot." 352

Dessewffy Gyula gróf (1909-2000) királytelki birtokából háromszáz hold mentesítését a szociáldemokrata Szakasits Árpád és kisgazda Tildy Zoltán kérelmezte. Azzal indokolták, hogy Dessewffy - aki ebben az időben a Független Kisgazdapárt sajtófönöke volt, majd nem sokkal később parlamenti képviselője lett - a Kis Újság címü lap (a kisgazdapárt országos terjesztésü újságja) engedélyét 1944. március 19-én a német megszállás napján „visszaadta azzal a megjegyzéssel, hogy Magyarország függetlensége megszünt és az elkövetkezendő szolgarezsimnek nem óhajt lapot szerkeszteni”. ${ }^{353} 1944-45$-ben politikai kiállása miatt mind a Gestapo, mind a nyilas államhatalom üldözte. A szintén kisgazda Balogh István által előterjesztett anyagot a bizottság támogatta. Ugyancsak mentesült Teleki Géza gróf (1911-1983) - az Ideiglenes Nemzeti Kormány vallás- és közoktatásügyi minisztere - ponyvádpusztai birtokából háromszáz hold. Kelemen Krizosztom (1884-1950) pannonhalmi bencés föapát kérését viszont elutasították. ${ }^{354}$

Az 1945. június 1-jei ülésen Erdei Ferenc, a Nemzeti Parasztpárt által jelölt kriptokommunista - belügyminiszter kijelentette: „Vannak olyan kérvények, amelyek

\footnotetext{
${ }^{347}$ Schiberna Ferenc Veszprém vármegyei nyilas főispán.

${ }^{348}$ MOL XVIII-5. Az 1945. június 1-jei ülés jegyzökönyve. 62.

${ }^{349}$ MOL XVIII-5. Az 1945. június 1-jei ülés jegyzökönyve. 62.

350 Shvoy Lajos székesfehérvári és Mindszenty József veszprémi püspökök esetében. Fontos hangsúlyozni, hogy mindkét esetben egyházmegyei földbirtokról van szó, nem pedig magántulajdonról!

${ }^{351}$ MOL XVIII-5. Az 1945. június 1-jei ülés jegyzőkönyve. 62. Felkiáltások: „Helyes!”; „Meg fogja kapni!”; „Ez jár!”

${ }^{352}$ Mindszenty József: Emlékirataim. Vaduz, 1988. (a továbbiakban: Mindszenty József, 1988) 71.

${ }^{353}$ MOL XVIII-5. Az 1945. június 1-jei ülés jegyzőkönyve. 63.

${ }^{354}$ MOL XVIII-5. Az 1945. június 1-jei ülés jegyzökönyve. 63-64.
} 
egyáltalán nem hivatkoznak politikai érdemekre [...] A gazdasági- és szakkérdések számunkra nem érdekesek." ${ }^{, 355}$ Erdei arra utalt, hogy több kérelemben a mintagazdaság jelleg és funkció szerepelt indokként a mentesítéshez. ${ }^{356}$ Balogh erre a következőket mondta: „Kérem, itt nagy dolgokról van szó és a látszatát is szeretném elkerülni annak, hogy talán könnyelműen bíráltunk el valamit és éppen a könnyelmüség miatt esett el valaki egy jogtól, amelyet a demokrácia is meg akar neki adni. Ezért a legaprólékosabban bíráltuk el e kérdéseket, természetesen mindig az igazság érdekében." ${ }^{357}$ Erdei határozottan megismételte „Akkor is csak a politikai érdemeket vizsgáljuk., 358

Zsedényi Béla, az Ideiglenes Nemzetgyülés és Politikai Bizottságának elnöke 1945. július 28-án 1323/1945. E. számmal levelet írt Nagy Imre földmüvelésügyi miniszternek, amelyben tájékoztatta, hogy a bizottság az 1945. július 21-ig „benyújtott mentesítési kérelmek közül 95 ügyet letárgyalt, abból 14 esetben a kérelemnek helyet adott, 11 esetben megállapította, hogy annak elbírálására nem illetékes és ezért úgy rendelkezett, hogy ezeket a kérelmeket Miniszter Úrhoz, illetőleg az Országos Földbirtokrendező Tanácshoz további eljárás céljából átteszi, 70 esetben pedig elutasította a kérelmet." 359

Balogh István már az 1930-as évektől sürgette a földbirtokreformot, valamint a szegényparaszti és mezőgazdasági cseléd réteg földhöz juttatását. Akkoriban a Szeged környéki tanyavilágban - ahol lelkészként szolgált - informális mezőgazdasági tanfolyamokat szervezett és létrehozta az ellenzéki Független Kisgazdapárt helyi csoportját.

Balogh 1944 végétől vezető kisgazda politikusként, miniszterelnökségi államtitkárként mind a saját, mind a pártja nevében kiállt a földreform szükségessége mellett. 1945 februárjában a kormány több tagjával Szegeden járt, hogy beszámoljanak addigi munkájukról a Szegedi Nemzeti Színházban tartott nagygyülésen. Ekkor elmondott beszédében Balogh többek között hangoztatta annak a fontosságát, hogy a föld azok kezébe kerüljön, akik megmüvelik, de - és ezzel csak a fönnálló helyzetet ismertette - nem adhatnak több földet, mint amennyi van. A helyi sajtó tudósítása

\footnotetext{
${ }^{355}$ MOL XVIII-5. Az 1945. június 1-jei ülés jegyzökönyve. 52.

${ }^{356}$ Vö. 600/1945. M.E. rendelet 16. paragrafusa.

${ }^{357}$ MOL XVIII-5. Az 1945. június 1-jei ülés jegyzökönyve. 52.

${ }^{358}$ MOL XVIII-5. Az 1945. június 1-jei ülés jegyzökönyve. 52.

${ }^{359}$ MOL XVIII-5. Az 1945. július 21-i ülés jegyzökönyve. Melléklet. 54-55.
} 
szerint az államtitkár szólt még a munka fontosságáról is, s kérte, hogy ne maradjon föld megmüveletlenül. Elmondta: tizenkét évig tanyán élt és látott már csodákat ott, ahol a munkabírás és a föld szeretete fütötte Szeged-alsótanya népét. A munkán kívül - fejezte be Balogh páter - még az Úristen segítsége és áldása szükséges ahhoz, hogy a föld kenyeret adjon. ${ }^{360}$

Az Ideiglenes Nemzetgyülés ülésszakai között jelentős feladatokat ellátó Ideiglenes Nemzetgyülés Politikai Bizottsága tagjaként Balogh István előadója volt a földreform alóli mentességet igénylők ügyeinek, valamint koordinálta az ezen ügyek előzetes vizsgálatára és véleményezésére létrehozott albizottság munkáját. Nagy Imréröl, mint az Ideiglenes Nemzeti Kormány földmüvelésügyi miniszteréröl így írt az 1960-as években: „Első nagy cselekedete volt a földreform. Ez normális menetünek indult. Az egyház is beleesett, de nem az egyház ellen irányult." ${ }^{\text {361 }}$

Shvoy Lajos székesfehérvári püspök 1946. április 15-én írt levelében azt panaszolta Balogh páternek, hogy noha az Ideiglenes Nemzetgyülés Politikai Bizottsága megítélte az egyházmegye számára a háromszáz kataszteri hold mentesítését a földreform céljaira való igénybevétel alól, azt nem érvényesítheti, mert a helyi földosztó bizottság belőle kétszáz holdat már szétosztott.

Shvoy Lajos leveléből: „A politikai bizottság a püspökök közül Mindszenty József hercegprímás úr volt veszprémi megyéspüspök úr részére és részemre mentesített a megváltás alól 300 hold fölingatlant. Értesülésem szerint a Hercegprímás Úr a mentesített föld birtokában is van. Nem látom tehát az indokot, miért éppen tőlem akarja az Országos Földbirtokrendező Tanács a megítélt 200 hold földet megtagadni." 362

Balogh a székesfehérvári püspöki birtok ügyében 1946. április 26-án írt Dobi István földművelésügyi miniszternek, aki az Országos Földbirtokrendező tanács illetékességére hívta föl a figyelmet és az ő döntésükre való várakozást javasolta. ${ }^{363}$ Így a páter közbenjárása ebben az ügyben nem járt sikerrel.

Ugyancsak 1946. április 15-én fordult Balogh államtitkárhoz Drahos János esztergomi érseki általános helynök is. Levelében kifejtette, hogy noha az esztergomi bazilika fönntartására, illetve a hercegprímási feladatkör ellátására való tekintettel több

\footnotetext{
${ }^{360}$ Délmagyarország, 1945. február 20.

361 BIV

${ }^{362}$ SZCSPL Hagyatékok. Balogh István iratai. (a továbbiakban: HBI) 107.

${ }^{363}$ SZCSPL HBI 111.
} 
föld is járna a főegyházmegyének, még a minimális száz kataszteri holdat sem utalták ki számukra. „Az igénylést mint káptalani helytartó a széküresedés alatt én nyújtottam be - írta Drahos. - Abban a meggyőződésben, hogy az érsek jogalanyisága mellett a hercegprímási méltóság és ügykör, a kapcsolatos költségek indokolttá teszik ennek külön jogalanyiságát, végül ilyennek ítéltem az ország első templomának, a bazilikának fenntartási terhét is és így háromszor 100 kat[aszteri]. hold földet igényeltem. Azóta folyton szorgalmazzák az ügyet új érsek és hercegprímás úr emberei is, de még az érseket kétségtelenül megillető 100 kat[aszteri]. hold sincsen kiutalva. Íme, így áll a gyakorlatba az ügy."364 Hiába írt Balogh páter ebben az ügyben is Dobinak, a földművelésügyi minisztertől a székesfehérvári esetre válaszoló levéllel megegyező tartalmú reakciót kapott. ${ }^{365}$

Természetesen az ügyek többségében a miniszterelnökségi államtitkár sikerrel lobbizott a kormánytagoknál és az állami szervek vezetőinél. Például a hajdúdorogi püspökség esetében, amiért is 1946. július 23-án Dudás Miklós görög katolikus püspök írt Baloghnak levelet, amelyben ,hálás köszönetet” mondott a görög katolikus egyházmegye fölbirtokreformmal kapcsolatos problémás ügyeinek képviseletéért és azok sikeres megoldásáért. ${ }^{366}$

\section{4. A katolikus egyházi érdekek képviselete}

1944-1945-ben több szegedi katolikus pap esett át igazoló bizottsági vizsgálaton, illetve került népbíróág elé. Hamvas püspök az ő szabadulások, vagy legalább körülményeik enyhítése miatt többször fordult Balogh Istvánhoz. Az államtitkári közbenjárások eredményesnek bizonyultak, s a szegedi lelkésze többsége hamar szabadult. Hamvas Endre 1945. november 27-én ezekért mondott köszönetet Baloghnak, akit egyben tájékoztatott arról is, hogy „Szegeden a letartóztatott papok ügyében lényegesen enyhült a helyzet", 367

\footnotetext{
${ }^{364}$ SZCSPL HBI 113.

${ }^{365}$ SZCSPL HBI 115.

${ }^{366}$ SZCSPL HBI 150.

${ }^{367}$ SZCSPL HBI 49.
} 
Balogh István számos esetben írt közbenjáró levelet Nagy Imre földmüvelésügyi miniszternek, illetve az Országos Földbirtokrendező Tanács vezetőségének. 1945 nyarán határozott hangú levélben kérte ez utóbbi testületet, hogy a földreform során még a látszatát is igyekezzenek elkerülni annak, hogy az a történelmi egyházak elleni intézkedés lenne.

Veres Péter, mint az Országos Földbirtokrendezö Tanács elnöke 1945. augusztus 3-án írt Balogh páternek az egyházi fölbirtokok tárgyában. Levelében kifejtette, hogy az egyházi birtokokkal kapcsolatos ügyeket ugyanúgy kezelik, mint a többi fölbirtokkal kapcsolatos vitás kérdést, illetve föllebbezést. Elismerte ugyanakkor Veres, hogy a földjeiktől megfosztott felekezeteknél ,a híveknek a jövőben fokozottabb mértékben kell egyházi adó, vagy természetbeni szolgáltatások formájában hozzájárulni az egyházfenntartási kiadásokhoz, mert a földmüvelő nép földhöz juttatása érdekében az egyházak földigényeit nem minden esetben lehet teljesen kielégíteni. És azt sem lehet kívánni, hogy más foglalkozású polgári rétegek számára a szegény parasztság tartsa el az egyházi intézményeket.",368

Klebelsberg Kuno vallás- és közoktatásügyi miniszter özvegyének az új hatalom 1945 nyarától nem folyósított nyugdíjat. Ezért Balogh páter 1945. október 19-én levélben fordult Oltványi Imre pénzügyminiszterhez, akitől a helyzet megoldását kérte. „Özv. gróf Klebelsberg Kunoné levéllel fordult hozzám - írta Balogh -, mely elmaradt illetményeinek folyósítását sürgeti. 1945. július óta egyáltalán nem kapott nyugdíjat és az Illetményhivatal a folyósítást, noha régen megígérte, egyáltalán nem teljesíti. Ez ügyben beadott kérelmének száma: V. K. Ö.2113. Kérem, Miniszter Urat, hogy özv. gróf Klebelsberg Kunoné kérelmét lehetőleg sürgősen kedvező elintézéshez juttatni és arról engem értesíteni szíveskedjék." ${ }^{369}$ Klebelsbergné azonban nemhogy nyugdíjat nem kapott a Rákosi-diktatúra idején, de ki is telepítették Budapestről. ${ }^{370}$ Majd az internálásból visszatérve Szegeden, a püspöki palotában - amelynek építését Klebelsberg olyannyira támogatta - talált menedéket, ahol Hamvas püspök nővérével együtt az első emelet Zrínyi utca felőli szobáit lakta 1964-ben bekövetkezett haláláig. ${ }^{371}$

\footnotetext{
${ }^{368}$ SZCSPL HBI 32.

${ }^{369}$ SZCSPL HBI 38.

${ }^{370}$ Vö. Klebelsberg Kunoné: Életutunk. S. a. r.: Máriaföldy Márton. Szeged, 1992. 85-105.

${ }^{371}$ Gyulay Endre kiérdemesült szeged-csanádi püspök (*Battonya, 1930. szeptember 17.) szóbeli közlése. 2010. október 6 .
} 
1945 nyár elején Balogh István és Varga Béla fölkereste Veszprémben Mindszenty Józsefet. Balogh páter ekkor arra kérte Mindszentyt, hogy keresse föl Vorosilovot, s mondjon köszöntet mind a marsallnak, mint Sztálinnak a szabadulásáért. Mindszenty ekkor kitért válasz elöl, Balogh azonban még később, egy budapesti találkozásukkor is forszírozta a dolgot, mire a későbbi hercegprímás határozottan nemet mondott. $^{372}$

1946. január 2-án Mindszenty József érdekes tiltakozó levelet írt Tildy Zoltán miniszterelnöknek. Úgy tudta ugyanis a hercegprímás, hogy a Vörös Hadsereg a Moson vármegyei Császárréten kétezer-négyszáz kataszteri hold földet szeretne tartósan bérbe venni, hogy ott települést hozzon létre, s oda ukrán családokat - akik közül kétszázan már meg is érkeztek Magyarországra - költöztessen.

Ez ellen a terv ellen tiltakozott Mindszenty: „Mint az ország hercegprímása a nemzet érdekeit tartva szem előtt e terv ellen, ha csakugyan fennáll, vagy csak szóba is jött, a leghatározottabban óvást emelek és tiltakozást jelentek be. Hangoztatjuk é joggal meg alappal, hogy az ide igazságtalanul átdobott magyar véreinket nem tudjuk csonka területünkön elhelyezni és eltartani, de ugyanakkor idegen nemzetbelieknek adnánk helyet. Ilyen eljárással magunk alatt vágnók a fát minden irányban." 373

Mindszenty levelére Tildy Zoltán megbízásából, az ő nevében Balogh páter írta meg a választ. A miniszterelnökség először Kovács Béla földmüvelésügyi államtitkárnál érdeklődött erről az állítólagos telepítési tervezetről, majd Tildy és Nagy Ferenc a Szövetséges Ellenőrző Bizottság tagjainál is rákérdezett az ügyre, ám mindkét helyről azt a választ kapták, hogy - mint Tildy lejegyezte Baloghnak - „semmi ilyen tény vagy terv nincs". ${ }^{374}$ Balogh ezeket összefoglalva fogalmazta meg a válaszlevelet a hercegprímásnak 1946. január 15-én.

Balogh István 1946. február 16-án - alig több mint két héttel a köztársaság kikiáltása és Tildy Zoltán köztársasági elnökké választása után - levelet írt Hamvas Endre csanádi püspöknek, amelynek arra kérte, tegye megfontolás tárgyává, illetve próbáljon meg hatással lenni Mindszentyre, hogy a magyar katolikus egyház - élén a hercegprímással és a felsőklérussal - fogadja el az új államformát, s tegyen gesztusokat a köztársaság vezetői és az új politikai berendezkedés reprezentánsai felé.

\footnotetext{
${ }^{372}$ Mindszenty József, 1988. 67-68.

${ }^{373}$ SZCSPL HBI 58.

${ }^{374}$ SZCSPL HBI 64.
} 
„Az egyház részéről a köztársaság és annak elnöke iránt bizonyos passzivitás érezhető. Az első három napban egyháziak és egyházközségek részéről érkeztek hozzám gratuláló táviratok. Azután látszat szerint - mint mondottam - mintegy titkos utasításra ezek teljesen megszüntek; egyetlen püspök sem üdvözölte.

Nem kívánom Nagyméltóságod felfogását, vagy álláspontját befolyásolni, mégis kérem, méltóztassék megfontolás tárgyává tenni, nem kellene-e mégis bizonyos közeledésnek jelt adni akár a papság, akár az egyházközségek útján. Egyébként is aggodalommal látom, hogy a viszony mindinkább romlik, holott most Őeminenciája ${ }^{375}$ hetek óta valóban a legteljesebb tartózkodást tanúsítja és a tüntetéseket az ő nevében olyanok provokálják, akik az antiszemitizmust szeretnék újra lángra lobbantani. Ez természetesen a nagyközönség előtt még nem áll tisztán, a munkáspártok sajtójának pedig nem áll érdekében a valóságot közölni.

Kívánatos volna megfontolás tárgyává tenni, nem volna-e alkalmas, ha Őeminenciája akár saját személyében, akár a püspöki kar nevében olyan nyilatkozatot adna, mely minden félreértést kizár, különösen a földreform és a legitimizmus tekintetében."376

Hamvas püspök erre 1946. február 21-én reagált. Levelében kijelentette, hogy mint az az egyház tanításából is következett - a monarchia híve volt, de köztársaság felé is illő tisztelettel és az állampolgároktól elvárható lojalitással lesz, s szót ejtett a szerinte szégyenletes Mindszenty-ellenes, illetve a bíboros melletti tüntetésekről is.

„A királyság híve voltam mostanáig - írta Hamvas Endre. - Ezt tudják rólam igen sokan. Vajjon nem joggal tarthattam-e attól, hogy nem hisznek érzelmeim őszinteségében és farizeusnak vagy szélkakasnak mondanak, ha most ennek ellenkezőjét juttatom kifejezésre? Vajjon én is úgy tegyek, mint néhai Balthazár református püspök ${ }^{377}$, aki rövid egymásutánban üdvözölte áradozva Károly királyt, Kun Bélát, a román királyt és Horthy Miklóst? Nekem, katolikus püspöknek ez etikai és pszichológiai lehetetlenség.

Tisztán ez volt az oka, hogy én nem üdvözöltem a köztársaságot és annak tiszteletreméltó elnökét, nem pedig valami ellenséges indulat vagy számító passzivitás. Államtitkár Úr tudja, hogy mi az Egyház tanítása az államformáról és az alattvalói

\footnotetext{
375 Öeminenciája = Mindszenty József.

${ }^{376}$ SZCSPL PHEI 500/1946.

377 Baltazár Dezső (1871-1936) 1911-től halálig a Debrecen székhelyủ Tiszántúli Református Egyházkerület püspöke.
} 
lojalitásról. ${ }^{378}$ Ehhez tartjuk magunkat és ez a köztársaságot csak segítheti. Semmiféle utasításról, mely az egyházközségeket elhallgattatta volna, nem tudok.

Ami végül a prímás személye ellen való tüntetéseket illeti, ezek a katolikus hívők tömegében mélységes ellenkezést támasztanak és nem alkalmas a bizalom felkeltésére a kormányzat iránt. A szegedi tüntetésen is táblákat vittek: »le Mindszentyvel« és kiabálták /igaz, hogy csak egy kis megszállott csoport/: »kötelet Mindszentynek! « ${ }^{379}$ - azonban magam láttam, hogy a felvonultatott munkások túlnyomó többsége a kényszeredettség unottságával vett részt a tüntetésben és talán nem csalódom, hogy szégyenlették." 380

1946. május 31-én Hamvas Endre - mint egyházi elöljárója - kánoni megintésben részesítette Balogh páter. Ennek indokai a következők voltak. A püspök szerint Balogh lakásán gyakran megfordultak nők - köztük színésznők is -, s ezekröl a sajtó is ír, ám Balogh soha nem tiltakozott az ilyen témájú cikkek ellen. Ezen kívül - így Hamvas - „hivatali müködésének olyan színezete van, mintha hivatalát egyéni anyagi célokra használná fel”, amivel „a papi állás tiszteletét rontja”. 381

Hamvas úgy tudta, hogy az államtitkár ,szinte mosolyogva nyilatkozott az egyházi javak elvételéröl”, valamint 1946 márciusában a Mindszenty és a Független Kisgazdapárt jobbszárnya elleni budapesti tüntetésekről - amelyben a hercegprímás jelképes koporsójával vonultak a tiltakozók - azt nyilatkozta: „komoly és érett, dicséretre méltó megmozdulás volt a munkáspártok részéről". 382

A föpap intése okaiként sorolta még a követezőket: Baloghot sokan korruptnak tartják, akinek „országárusító” tevékenységét maga Miklós Béla miniszterelnök is

\footnotetext{
${ }^{378}$ Aquinói Szent Tamás (1224-1274) - akinek modernizált tanítása (a neotomizmus) a tizenkilencedik század második felétől a második vatikáni zsinatig (1962-1965) az egyház hivatalos álláspontja volt szerint az ideális államforma - teológiai alapokon - a monarchia

379 1946. február 14-én Csongrád vármegye székhelyén, Hódmezővásárhelyen is tüntettek a baloldali pártok hívei azt skandálva, hogy „Le a reakcióval, le a fasizmussal, vesszen a reakciós hercegprímás!” (Vásárhely Népe, 1946. február 15.) De több mint egy hónappal később, a Baloldali Blokk megalakulásának idején is ezek voltak a vásárhelyi tüntetők jelszavai (a „Kisgazdapárt jobbfele, közéletből kifele!” mellett): „Munkát, kenyeret, Mindszentynek kötelet!” „Le a reakcióval, vesszen a reakciós sváb Mindszenty!” (Vásárhely Népe, 1946. március 12.)

${ }^{380}$ SZCSPL PHEI 500/1946.

381 Állambiztonsági Szolgálatok Történeti Levéltára. (a továbbiakban: ÁBTL) A Mindszenty-ügy vizsgálati dossziéja. 3.1.9. V - 700/44. (a továbbiakban: 3.1.9. V - 700/44.) 15.

382 ÁBTL 3.1.9. V-700/44. 15.
} 
bírálta, ám a páter ezt nem kérte ki magának, illetve nem utasította vissza; államtitkárként asszisztált a kormány erkölcsileg kifogásolható (például a házasság felbontási eljárásnak egyszerüsítése) intézkedéseihez; a püspöki kar 1945. októberi választási körlevele elleni politikai támadásokban szerepelt vállalt. Sőt, Hamvas még azt Balogh páter - mint egy ideig a sajtóügyekért is felelős kormánytag - számlájára írta, hogy ,a magyar katolikusoknak nincs napilapja”. ${ }^{383}$

A kánoni intés végén a csanádi püspök azt javasolta papjának, hogy Budapesten ne tartson fönn külön lakást, hanem „lakjék inkább valamely zárdában vagy egyházi intézményben”, valamint „hivatali állásában kerülje az anyagiak körül való vádak lehetőségét". ${ }^{384}$ A főpásztor már ekkor kilátásba helyezte, hogy amennyiben ezeken a páter nem változtat, egyházi felsőbbsége gondoskodni fog a föntebb leírt helyzet megszüntetéséröl. Ez később - Balogh egyházi szolgálatának fölfüggesztésével - meg is történt.

Hamvas a kánoni megintés - amelynek adására a püspök Mindszentytől kapta az utasítást - indokai között utalt Miklós Béla sértő bírálatára és vádaskodására. Ennek az alapja az volt, hogy Teleki Géza gróf, polgári demokrata politikus, az Ideiglenes Nemzeti Kormány egykori vallás- és közoktatásügyi minisztere 1945 decemberében családjával együtt három hetet töltött Grősz József vendégeként a kalocsai érseki palotában. Teleki azokban a napokban az egyik közös étkezés után - több tanú jelenlétében - a következő történetet mesélte el Grősznek.

„Ez év októberében - mondta Teleki Géza a miniszterelnök úrnak, Dálnoki Miklós Bélának dolgozószobájában voltam Balogh István min[iszterelnökségi]. államtitkár úrral együtt. Ekkor a miniszterelnök nekitámadt Balogh Istvánnak, mert egy körözvényt írt alá a miniszterelnök nevében a miniszterelnök tudta nélkül. A körözvényben béremelésről volt szó, amit így akartak keresztülvinni. Azután a min[iszter].elnök ezt mondta Balogh Istvánnak: »Tudod, mi vagy Te? Országárusító gazember?« - Balogh ezt szó nélkül tudomásul vette. A min[iszter].elnök folytatta: »Azt hiszed, én nem tudom, mi folyik itt mellettem a te szobádban? Nekem dokumentumaim vannak! «Balogh erre sem szólt egy szót sem." 385

\footnotetext{
${ }^{383}$ ÁBTL 3.1.9. V - 700/44. 16.

${ }^{384}$ ÁBTL 3.1.9. V - 700/44. 17.

${ }^{385}$ ÁBTL 3.1.9. V - 700/44. 51.
} 
Mindezekről a kalocsai érsek tájékoztatta Mindszentyt, s az ügyről jegyzőkönyvet is készítettek Esztergomban 1946. április 11-én, amelyet mind Grősz József, mind Gombos Károly kalocsai érseki irodaigazgató saját kezüleg aláírt.

1946 júliusának elején Rajk László belügyminiszter több mint kétszáz egyesületet oszlatott föl. Ezek között volt - Szviridov altábornagy kifejezett kérésére - a KALOT is. Az 1946. július 8-i pártközi értekezleten ez az ügy is szóba került. Az elnöklő Nagy Ferenc miniszterelnök mellett a szintén kisgazda Varga Bála házelnök és Balogh páter is hibás döntésként értékelte a KALOT föloszlatását. Attól tartottak ugyanis, hogy így a jogaikban korlátozott és sértett katolikus tömegek az állammal szembe még bizalmatlanabbá válnak, s inkább Mindszenty politikai törekvéseit fogják támogatni. Rákosi ekkor azzal vádolta meg Baloghot, hogy a nyilvánosság előtt - a Magyar Nemzet hasábjain - a katolikus egyház érdekeit képviseli az állam érdekeivel szemben. ${ }^{386}$

1946 júliusában a budapesti katolikus egyesületek küldöttsége kereste föl Balogh Istvánt hivatalában, $\mathrm{s}$ tiltakozott a civil szervezeteke korlátozó belügyminiszteri intézkedések ellen. Balogh megnyugtatta öket, hogy a hitbuzgalmi egyesületek a továbbiakban is szabadon müködhetnek, $\mathrm{s}$ csak a hatóságok által jóváhagyott alapszabály szerint működő csoportok tartoznak a belügyminiszter felügyelete alá. ${ }^{387}$

Ortutay Gyula vallás- és közoktatásügyi miniszter 1947 márciusában - mint a Független Kisgazdapárt javaslatát - a vallás- és lelkiismereti szabadságra hivatkozva fölvetette az iskolai hitoktatás fakultatívvá tételének szükségességét (az elképzelés persze a Magyar Kommunista Párttól származott, amelynek titokban Ortutay is tagja volt 1945 márciusától). Ez ellen óriási tiltakozó hullám indult meg, amelynek során tüntetések, politikai csatározások, sajtópolémiák útján próbált álláspontjának nyomatékot adni mindkét tábor.

A magyar katolikus püspöki kar nevében Mindszenty természetesen tiltakozott Ortutay javaslata ellen, amit a pártközi értekezlet - és annak résztvevőjeként Balogh - is elfogadott. Hamvas Endre 1947. március 17-én kelt levelében kért választ Baloghtól arra, hogy a fakultatív hitoktatás bevezetésének kérdésében a pártja, vagy az egyháza álláspontját képviseli-e. ${ }^{388}$

\footnotetext{
${ }^{386}$ Vö. PÉ, 2003. 258-261.

${ }^{387}$ Kis Újság, 1946. július 24.

${ }^{388}$ Haas György, 2010. 122.
} 
Balogh páter 1947. március 22-én válaszolt főpásztorának. Tájékoztatta Hamvast, hogy a pártközi értekezleten a parasztpárti Farkas Ferenc - persze megfelelő alap nélkül - állította, hogy a magyar katolikus egyház vezetése nem emel kifogást a fakultatív hitoktatás bevezetése ellen. Leírta továbbá, hogy Bánáss László veszprémi püspök az ügyben mind a miniszterelnökkel, mind a parlamenti pártok vezetőivel tárgyalásokat folytatott, amelyek során kiderült, hogy a kisgazdapárti politikusok egy része - élén Nagy Ferenccel, Varga Bélával és Balogh Istvánnal - a helyzet a katolikus egyház számára megnyugtató módon történő mielőbbi rendezése mellett van. Ugyanakkor Balogh kijelentette, hogy amennyiben a kormány olyan álláspontra helyezkedne, ami lelkiismeretével és papi hivatásával összeegyeztethetetlen, le fogja vonni a szükséges konzekvenciákat. ${ }^{389}$

${ }^{389}$ Vö. Haas György, 2010. 123-127. 


\section{A KÉKCÉDULÁS VÁLASZTÁSOKTÓL AZ INTERNÁLÁSIG}

\section{1. A Független Magyar Demokrata Párt elnöke}

Baloghnak a kisgazdapártot fölörlő, kommunista irányítású szalámipolitikában sajátos szerep jutott. Az 1947. március 1-jei pártközi értekezleten Balogh páter - mint az FKGP újdonsült fötitkára - kifejezte pártja elköteleződését a koalíció további fönntartása mellett. „A Független Kisgazdapárt abból a szempontból indul ki fogalmazott -, hogy a koalíciót a további előrehaladás egyedüli feltételének és útjának ismeri. Ezért a Kisgazdapárt a maga részéről mindent meg akar és meg fog tenni aziránt, hogy a koalíció megmaradjon és az együttmüködés a pártok között minél harmonikusabb legyen. Szükséges ezért, hogy a koalíciós pártok az eddigi metódustól eltérően a Kisgazdapártot a demokrácia szempontjából is egyenrangúnak fogadják el.” Kifejtette továbbá, a hogy a baloldali pártok részéről megfogalmazott bírálatokat szem előtt tartva igyekszik a párt belső életét, valamint politikai és kormányzati helyzetét újragondolni. ${ }^{390}$

Balogh fötitkárként jelentős szerepet vállalt a párton belüli további tisztogatásokban, azaz az FKGP jobbszárnyának folyamatos ellehetetlenítéséhez. Persze ebben egyrészt külső - a Baloldali Blokk részéről jövő - nyomásnak, másrészt belső - a kisgazdapártban lévő kriptokommunisták (például Ortutay Gyula vagy Dobi István) felöl jövő - pressziónak is engedelmeskedett. Ahogy az 1947. július 11-i pártközi értekezleten mondta: „Mindent vállalunk és mindent meg akarunk tenni a Baloldali Blokk kívánságán túlmenően is, nem a Baloldali Blokk kedvéért, hanem a saját tisztaságunk érdekében tesszük meg a nagy tisztogatásokat." ${ }^{391}$

Balogh István 1947. május végén Rákosival többször egyeztetett Nagy Ferenc miniszterelnök távozásáról. Jelen volt azon a kormányülésen, amelyen hazahívták a

\footnotetext{
${ }^{390}$ PÉ, 2003. 444-446.

${ }^{391}$ PÉ, 2003. 494.
} 
kormányfőt. Rákosi Mátyás visszaemlékezései szerint Balogh és ő beszélt telefonon Naggyal a lemondás részleteiről. Ott volt még Jékely László és Ortutay Gyula is. Viszont beszélni csak ketten beszéltek vele. ${ }^{392}$ Balogh Nagy Ferenc kérései közül kisfiának kijuttatása Svájcba, munkatársainak büntetlensége stb. - közül csak az elsőt garantálta. Nagy Ferenc - miután a gyermeket átadták neki Genfben - 1947. június 1jén lemondott. ${ }^{393}$

„Balogh István ezekben a napokban - írta ugyancsak Rákosi - igyekezett a kezemre járni. Nagy Ferenccel kölcsönösen nem állhatták egymást, de ami számára még fontosabb volt, azt remélte, hogy miután Kovács Béla és Nagy Ferenc eltüntek a politikai porondról, ő lesz a kisgazdapárt vezető alakja. Persze erről így nem beszélt velem - s én erre egyetlen szóval sem céloztam -, de láttam, hogy magatartásában ilyen tervei is közrejátszanak." 394

Nem sokkal később azonban - Dinnyés Lajos kormányának megalakulásakor Baloghnak távoznia kellett a miniszterelnöki hivatalból. Rákosi emlékei szerint „Dinnyés kinevezésével egy időben menesztettük Balogh Istvánt is, aki addig annyi jobboldali borsot tört az orrunk alá. Balogh addig ragaszkodott államtitkári állásához, hivatkozott arra, hogy bírja a kisgazdapárt bizalmát. Megmagyaráztam neki, hogy ez a változott politikai viszonyok között már nem elég, azt ilyen fontos poszt viselőjének a kommunista párt bizalmával is rendelkeznie kell, márpedig mi nem bízunk meg benne. Baloghnak volt magához való esze, s miután megértette, hogy ebben a kérdésben hajthatatlanok vagyunk, nehéz szívvel búcsút vett ettől a poszttól, ahol ahhoz képest, hogy elözőleg tanyai pap volt, időnként komoly politikai intrikákat tudott kifejteni. Utólag jó arcot csinált e fordulathoz, s én is megmondtam neki, hogy bizonyos érdemei fejében az eddiginél kisebb politikai müködése elé mi nem fogunk akadály gördíteni.",395

Balogh István 1947. július 3-án - mint a párt fötitkára - levelet írt Dobi Istvánnak, a kriptokommunista pártelnöknek. Ebben megromlott egészségére hivatkozva négyheti szabadságolását kérte. Ezt követően kilépett a pártból, s új politikai

\footnotetext{
392 Rákosi Mátyás, 1997. 378.

${ }^{393}$ Vö. Nagy Ferenc: Küzdelem a vasfüggöny mögött. 2. köt. Budapest, 1990. 150.

${ }^{394}$ Rákosi Mátyás, 1997. 379.

${ }^{395}$ Rákosi Mátyás, 1997. 382.
} 
formáció hozott létre, a Független Magyar Demokrata Pártot. Lépéséröl előre tájékoztatta Rákosi Mátyást, aki nem ellenezte, sőt: támogatásáról biztosította. ${ }^{396}$

A Magyar Nemzet 1947 júniusának elején közölte, hogy „Balogh Istvánnak már két hónap elött szigorú orvosi utasításra meg kellett volna szakítani közéleti munkáját és orvosi kezelésnek kellett volna alávetnie magát. Az a fontos megbízatás azonban, amelyet a Kisgazdapárt bizalma folytán vállalt, nem tette lehetővé, hogy akár napokra is megszakítsa munkáját. A két fontos poszton végzett megfeszített munka annyira megviselte egészségi állapotát, most már visszavonhatatlanul abba kell hagyni közéleti tevékenységét, ezért hosszabb szakorvosi gyógykezelésre az egyik fővárosi szanatóriumba vonul."397

A lap megkérdezte a Korányi András professzort is a páter egészségi állapotáról, aki a következő tájékoztatást adta: „Legfőbb ideje, hogy makacs paciensem végre rászánja magát a szakorvosi kezelésre, aminek szükségére az utóbbi hónapokban több ízben figyelmeztettem. Mindössze annyi eredménye volt intelmeimnek, hogy két ízben rövid szanatóriumi kezelésnek vetette alá magát. Sajnos még a legszigorúbb elöírásaimnak sem tehetett eleget, pedig a természet ellen a rendkívüli munkabírása sem veheti fel tartósan a küzdelmet." 398

Balogh a nyilvánosság előtt jó egy hónappal később tünt föl ismét. Ekkor nyilatkozta lapjának, hogy távolléte kapcsán számos pletyka keringett: „az egyik híresztelés szerint az Andrássy út 60. alá kerültem, egy másik fantáziadúsabb hír eddig arról szólt, hogy parasztok Ausztriába síboltak, meglehetősen romantikus körülmények között: gyümölcsös kocsin, kofának maszkírozva. Volt olyan hír is, hogy eltűntem." ${ }^{399}$ Természetesen a politikai változásokról - távozásáról a miniszterelnökségi államtitkárságból, illetve a kisgazdapárt főtitkári székéből - is beszélt. „Kimaradásom a kormányból egészen természetes volt - fogalmazott a páter -, a kisgazdapárti főtitkári székből történt távozásom pedig az azóta megváltozott politikai helyzettel van szoros összefüggésben."

\footnotetext{
${ }^{396}$ Izsák Lajos: Polgári ellenzéki pártok Magyarországon. 1944-1949. Budapest, 1983. (a továbbiakban: Izsák Lajos, 1983) 161.

${ }^{397}$ Magyar Nemzet, 1947. június 4.

${ }^{398}$ Magyar Nemzet, 1947. június 4.

${ }^{399}$ Magyar Nemzet, 1947. július 20.

${ }^{400}$ Magyar Nemzet, 1947. július 20.
} 
Kovács Imre Levél Balogh Istvánhoz címü cikkével indokolta, hogy miért csatlakozik a Független Magyar Demokrata Párthoz. Írásában leszögezte, hogy Magyarországnak nincs más választása, mint a Szovjetunióval való szoros külpolitikai szövetség, s hogy a magyarság különböző társadalmi rétegeinek mind a politika, mind a gazdaság terén össze kell fogniuk és együtt kell müködniük az ország újjáépítése érdekében. Ugyanakkor kifejezte elkötelezettségét a demokratikus állami berendezkedés mellett, amely szerinte „mégiscsak ideálisabb és megfelelőbb, min a fasiszta és totalitárius". 401

A Balogh-párthoz való csatlakozását a következőképpen indokolta az egykori parasztpárti politikus. „A demokráciát nem lehet egy osztály számára kisajátítani, a demokráciában elfér minden osztály, elfér benne a parasztság, a munkásság, a polgárág és az értelmiség, hiszem: hogy a Független Magyar Demokrata Párt, illetve a független magyarok pártja összegyüjti azokat a valóban független magyarokat, akik minden befolyás, presszió, terror ellenére és alól függetleníteni tudják magukat, hogy meggyőződésüknek megfelelö politikát csináljanak. Csak így tarthatjuk meg, független magyarok, Magyarországot függetlennek."402

Kovács Imre emlékirataiban a következőképpen indokolta az FMDP-hez való csatlakozását. „Három lehetőségem volt; Barankoviccsal indulok, aki szívesen látott volna, de református lévén, nem akartam felfokozott vallási hullámmal bejutni a parlamentbe. Pfeiffer Zoltán szintén számított rám, de az ajánlásokkal kapcsolatos hercehurca elriasztott. Maradt Balogh páter pártja, a független demokrata párt, amely engedélyezett volt; nem kellett jelentkeznem, az atya hívott egy reggel, hogy csatlakozzak hozzájuk. Elfogadtam azzal a kikötéssel, hogy a velem együtt belépőkkel mi független parasztpártként szerepelünk."403

Ugyanitt jellemezte Balogh páter politikai karakterét is. „Ha egy magyar politikusról el lehet mondani, hogy »political animal«, született politikus, akkor a páter tényleg az volt. Sok mindent beszéltek róla, korruptnak tartották, mesés képgyüjteménye volt, gyönyörü lakása, villája; elég könnyelműen élt, szeretett jól enni, inni, szerette a jó társaságot, a privát szórakozást, találkákat. Ez mind igaz (és ki ne szeretné), de politikailag megbízható volt, csak a magyarság, az ország érdekeit nézte. Engedett a kommunistáknak, ha kellett, de hihetetlen éberséggel és eszességgel követte

\footnotetext{
${ }^{401}$ Magyar Nemzet, 1947. augusztus 14.

402 Magyar Nemzet, 1947. augusztus 14.

${ }^{403}$ Kovács Imre, 1990. 320.
} 
a fejleményeket, minden rezdülésre felfigyelt, kereste a kiutat a válságokból, igyekezett menteni a menthetőt. A gyorsan változó politikai konstellációkban próbálta a polgári, nem kommunista erőket átcsoportosítani, azonos érdekűeket összehozni; spekulált, kalkulált és taktikázott a túlerővel szemben. Helyét a történelemben talán nem lehet egy Martinuzzi mellett kijelölni, de kétségtelenül György barát ikertestvére volt.”,404

A kisgazda Kis Újság a választási esélyeket latolgató cikkében még helytelenül Független Nemzeti Demokrata Pártnak nevezi Balogh szervezetét ${ }^{405}$, míg néhány nappal később két külön organizációként kezeli a Független Magyar Demokrata Pártot és a „Balogh-féle pártot”. ${ }^{406} \mathrm{Az}$ FKGP sajtója egyébként végig követte a kisgazdapárt „utódpártjainak” - a Pfeiffer Zoltán és a Balogh István vezette csoportosulásoknak - a választási készülődését. Tudósított arról is, hogy Balogh a választáson való induláshoz „a püspöki kartól megkapta az engedélyt és ennek az engedélynek az alapján most már biztosra vehető mind pártjának, mind az ő személyének részvétele az új választásokon." ${ }^{407}$

Dobi István államminiszter, az FKGP elnöke 1947. július 27-én a párt kisbéri kenyérünnepén és nagygyülésén beszélt a párt széteséséről és politikai térvesztéséről is - természetesen ezeket a tendenciákat párton belüli ellenfelei nyakába varrva. „A pártvezetésben erőre kapott egy helytelen irányzat, amiről azt mondhatnám, hogy bent ülünk a kormányban és a magunk ellenzéke lettünk. Hiba volt, mert minél jobban belemélyedtünk ebbe, annál kevesebbet bíztak bennünk a többiek és éppen azért, mert nem bíztak - amin mostmár nehéz is volna csodálkozni -, nemhogy arányosították volna a közigazgatást, a rendészetet, a gazdasági kulcspozíciókat, de inkább igyekeztek minél szükebb területre szorítani a Kisgazda Párt befolyását. És ez különböző dolgok közrejátszásával sikerült is nekik."408

Az FMDP 1947 júliusában bontott zászlót. Első nyilatkozatban Balogh páter kijelentette: „Hangsúlyoznom kell, hogy az új párt nem tagja a koalíciónak, de ez nem jelenti, hogy harcot hirdet a koalíció ellen. Ellenkezőleg, az új párt a koalíciónak konstruktív ellenzéke kíván lenni, kritikát gyakorol. De nem az ellenségeskedés

\footnotetext{
${ }^{404}$ Kovács Imre, 1990. 320-321.

${ }^{405}$ Kis Újság, 1947. július 27.

${ }^{406}$ Kis Újság, 1947. augusztus 1.

${ }^{407}$ Kis Újság, 1947. július 27.

${ }^{408}$ Kis Újság, 1947. július 29.
} 
kedvéért, hanem az építés szolgálatában."409 Az FMDP polgári pártként értelmezte magát, különbséget tett azonban „polgár” és „demokratikus polgár” között. Utóbbiak képviseletét vállalta föl.

A pártban jelentős szerephez jutott a Magyar Nemzet vezető publicistája, Parragi György és a Nemzeti Parasztpárt egykori főtitkára, majd alelnöke, Kovács Imre. Dénes István, a Magyar Földmüves és Munkáspárt volt vezetője augusztusban csatlakozott Balogh páterhez. Ekkor próbálkozott a Kossuth Párt újjászervezésével P. Ábrahám Dezső, aki végül szintén az FMDP-ben kötött ki.

Az FMDP 1947. augusztus 1-jén közreadott programjában a párt elkötelezte magát a polgári szabadságjogok biztosítása és a magántulajdon védelme mellett. A párt követelte az Apostoli Szentszékkel való diplomáciai kapcsolatok rendezését. Ezt a követelést egyébként a magát világnézeti, de nem felekezeti pártként meghatározó Demokrata Néppárt főtitkára, Barankovics István is megfogalmazta a párt győri kampánynyitó gyülésén. ${ }^{410}$

Balogh nyilatkozatban ítélte el a szélsőjobboldali erőket és állt ki a polgári demokrácia értékei mellett. „Mi ellenzékiek akarunk maradni - jelentette ki -, de építő formában... Abból, hogy mi konstruktív ellenzék vagyunk, a demokráciának csak haszna lehet. Nagyon tévednek, akik azt hiszik, hogy ennek a pártnak bármi köze is lehet a reakcióhoz. Ne higgye senki, hogy azok, akik a kisgazdapárt szélsőjobboldalán állnak és kifelé áll a rúdjuk, itt menedéket találnak. Figyelmeztetek mindenkit, aki tőlem jobbra áll, az kockázatos politikába megy bele, ami katasztrófát jelenthet azok számára, akik követik, de az ország számára is."411

A Független Magyar Demokrata Párt az 1945-ös Független Kisgazdapárt értékeinek letéteményeseként állította be magát. Sulyok Dezső - még másfél évvel korábban - Mivégre vagyunk a földön? címü, az A Holnap, a Magyar Szabadság Párt lapja első számában közölt cikkében is hasonlókat fogalmazott meg, hiszen saját szervezetéről is azt állította: az 1945-ös kisgazdapárt utódja. Sulyok szerint az MKP „egy nagyon kisszámú, de nagy akarású és öncélú politikát folytató csoport”, amely már 1945 novemberétől arra törekszik, hogy az FKGP-n belül megosztást és ellenségeskedést szítson, ezzel pedig a többségből kisebbséget, a kisebbségből pedig

\footnotetext{
${ }^{409}$ Balogh Sándor - Izsák Lajos: Pártok és pártprogramok Magyarországon. 1944-1948. Budapest, 1977. (a továbbiakban: Balogh Sándor - Izsák Lajos, 1977.) 93.

${ }^{410}$ Hazánk, 1947. augusztus 17.

${ }^{411}$ Izsák Lajos, 1983. 163.
} 
többséget csináljon. A pártelnök kifejtette, hogy politikájuk alapja - akárcsak Balogh pártjáé - ,a keresztény erkölcs, a nemzeti gondolat, a tiszta demokrácia és a szociális kiegyenlítődés szolgálata." 412

Az FMDP keresztény és polgári értékrendet vallott magáénak, noha a kormányt és a baloldali pártokat soha nem bírálta olyan keményen, mint a Pfeiffer Zoltán vezette Magyar Függetlenségi Párt és a Barankovics István nevével fémjelzett Demokrata Néppárt. A polgári ellenzék politikai erői Baloghot és híveit „műellenzékiséggel” vádolták - nem minden alap nélkül. A Somogy megyei választókhoz intézett levelében a pártvezetés a következőket írta: „A Független Magyar Demokrata Párt politikája a Kisgazdapárt 1945-ös politikája. A Balogh-párt az igazi Kisgazdapárt. A Kisgazdapártból éppen a legharcosabb embereket kényszerítették kilépésre. Jelszavunk: Isten, haza, család. Célunk: Munka, kenyér, biztonság." $" 413$

Az FMDP kivette részét a választási kampányból. Lapja, a Magyar Nemzet csaknem másfél hónapig kizárólag a kampányeseményekről számolt be, valamint a választási polémiáknak biztosított terepet.

A párt újságja a Szociáldemokrata Pártot bírálta, míg a röpcédulákon és szórólapokon a Nemzeti Parasztpárt és a Független Kisgazdapárt politikája ellen foglaltak állást. A párt vezetői 1947 nyarán közel ötszáz politikai gyülést tartottak, szerte az országban. Az FMDP - egyedül az ellenzéki pártok közül - valamennyi választókerületben listát tudott állítani. A legtöbb lajstrom élén - a mandátum biztosítása miatt - maga Balogh István pártelnök állt, ellenben a bizonytalan országos listát nem ő vezette. A párt jelöltjei között találjuk Sz. Szabó Pál volt parasztpárti népjóléti államtitkárt, Molnár Józsefet, a parasztpárt egykori budapesti főtitkárát, Bartha Lászlót, a Nemzeti Parasztpárt volt Szabolcs megyei elnökét. A párt jó esélyekkel indult a választásokon, hiszen jelöltjei tapasztalt, ismert politikusok voltak, akik a sajtón és a választási beszédeken keresztül gyorsan népszerüsíteni tudták az FMDP-t.

Meg kell említeni Parragi György augusztus 28-i rádióbeszédét, amelyben kifejtette, hogy a Balogh-párt is ellenzéki erő, de nem ellensége a népi demokráciának, a haladásnak. „Nyíltan megmondjuk, hogy nem vagyunk marxisták, de becsüljük a munkáspártok erőfeszítéseit az ország újjáépítése körül. Programunk a szabad emberi életforma biztosítása. Mi támogatjuk a hároméves tervet, de ugyanakkor ügyelni fogunk

\footnotetext{
${ }^{412}$ A Holnap, 1946. március 15.

${ }^{413}$ Izsák Lajos, 1983. 190.
} 
arra, hogy a terv megvalósítása ne kerüljön összeütközésbe az emberi szabadságjogokkal és ne bénítsa meg a szabad vállalkozás szellemét."414

1947 augusztusában - a kánonjogi elöírásoknak megfelelően - Balogh páter a választásokon való indulásra engedélyt kért nemcsak az személye kapcsán illetékes ordináriustól - Hamvas Endre csanádi püspöktől -, de minden püspöktől és érsektől, akinek az egyházmegyéje területén jelöltként föllépett.

S mivel - mint már említettem - Balogh nemcsak a Független Magyar Demokrata Párt országos lajstromát vezette, de valamennyi választókerületben az ő neve szerepelt a lista élén, így az összes magyarországi katolikus föpásztortól engedélyt kellett kérnie. A többség mindezt csak formalitásnak tekintette és szükszavú levélben engedélyezte a páternek az indulást egyházmegyéje területén. Virág Ferenc pécsi püspök ugyanakkor a hercegprímás hozzájárulásától tette függővé a dolgot, vagyis az ő engedélyét akkor kellett érvényesnek tekintetni, ha Mindszenty is hasonló tartalmú rendelkezést ad ki az esztergomi érsekség területére.

Pétery József váci püspök 1947. augusztus 19-i levelében adta hozzájárulását ahhoz, hogy a páter egyházmegyéje területén képviselőjelöltséget vállaljon. Ám hozzátette: „Minthogy a Püspöki Kar a választásoktól távol tartja magát, meg kell említenem, hogy ez az engedély nem jelenti Pártelnök Úr programjának helyeslését."415

Az 1947. augusztus 31-i választáson a Független Magyar Demokrata Párt a szavazatok 5,2\%-át szerezte meg, ezzel 18 parlamenti mandátumhoz jutott. A párt PestPilis-Solt-Kiskun (10,1\%), Hajdú-Bihar $(10,0 \%)$ és Jász-Nagykun-Szolnok $(8,7 \%)$ kerületben volt a legerősebb, Vas $(0,6 \%)$, Baranya-Tolna $(0,9 \%)$, Zala $(1,1 \%)$ és Csongrád (1,6\%) kerületben azonban gyöngén szerepelt. A többi választókerületben a szavazatok 5-7\%-át tudta megszerezni. ${ }^{416}$

1947 szeptember első napjaiban Balogh páter tárgyalásokat kezdeményezett az FMDP és az FKGP között. Ennek eredményeként a vezetők szeptember 5-én jegyzőkönyvet írtak alá a két párt egyesüléséről, amely azonban csak fúzió tényét rögzítette, konkrét szervezeti, személyi, vagy politikai kérdéseket nem érintett. Erről az FMDP szeptember 7-én közleményt adott ki. „A választások utáni napokban a Független Kisgazda Párt és a Független Magyar Demokrata Párt vezetőségi tagjai

\footnotetext{
${ }^{414}$ Izsák Lajos, 1983. 192.

${ }^{415}$ SZCSPL HBI 263.

${ }^{416}$ Lásd bővebben: Szerencsés Károly: Predesztinált választások. 1947. In: A magyar parlament. 19441949. Szerk. Hubai László és Tombor László. Budapest, 1991. 105-142.
} 
tárgyalásokat kezdtek abból a célból, hogy a két párt közötti együttmüködést megbeszéljék. A megbeszélések során a két párt vezetősége között elvi megállapodás jött létre, amelyben kijelentik, hogy a magyar nép, főleg a parasztság érdekeit pártérdekek fölé kell helyezni, ezért kifejezték készségüket, hogy a két párt között a legbensőségesebb kapcsolatot teremtik meg."

A két párt egyesülésének szándéka nagy föltünést keltett a politikai életben. Az elvi döntés azonban - a baloldali pártok határozott tiltakozása miatt - nem realizálódhatott.

A Nemzeti Parasztpárt vezetősége egyértelműen leszögezte: „Balogh nem térhet vissza a koalícióba”. 1947 szeptembere után az FMDP képviselőcsoportjával és parlamenti szereplésével volt elfoglalva. Nem szervezett alapszervezet, nem toborzott párttagokat, s egyre ritkábban fordult közvéleményhez. A párt lojális volt a kormányhoz. Ez elkülönítette a többi polgári ellenzéki párttól, s az elszíntelenődésének és a politikai térvesztésének is ez volt az oka. A képviselők egy része - köztük Balogh István - csatlakozott a népfrontpolitikához, s 1949-ben már a Magyar Függetlenségi Népfront egységes listájáról jutott mandátumhoz. ${ }^{418}$

Az FMDP kormány melletti elkötelezettségére jó példa, hogy P. Ábrahám Dezső 1947 őszén, a Dinnyés-kormány programja kapcsán így fogalmazott: „Mi nem akarunk a kákán is görcsöt keresni. Mi ellenzéki párt vagyunk, fenntartjuk magunknak a kritika jogát, ami természetesen joga minden ellenzéknek, sőt a napokban volt szerencsém a kommunista párt egy igen tiszteletre méltó vezetőjével beszélni, aki a beszélgetés alakalmával szinte felhívta és feljogosította az ellenzéket arra, hogy még irányító tevékenységet is gyakoroljunk a kormányzati programban. Ennek is szívesen eleget teszünk ama nagy cél érdekében, hogy ezt az országot a mai válságos és kétséges helyzetéből mielőbb ki tudjuk emelni."

Az MKP Politikai Bizottsága 1947. szeptember 1-jén értékelte a választási eredményeket. A testület Nemzeti Parasztpárt eredményét üdvözölte, a szociáldemokratáknál és kisgazdáknál pedig a nem túl fényes választási szereplés után a balszárny gyöngülésétől tartott. A DNP-ről megállapította, hogy „,a nem politizáló és az egyházi vezetés menők pártja” - holott ez a párt vezetésére egyáltalán nem volt igaz -, az MFP pedig ,a magyar fasizmus, a reakció, a demokrácia elszánt ellenségeinek

\footnotetext{
${ }^{417}$ Balogh Sándor - Izsák Lajos, 1977. 121.

${ }^{418}$ Nehéz esztendők krónikája. Szerk. Balogh Sándor. Gondolat Kiadó, Budapest, 1986. 49-50.

${ }^{419}$ Balogh Sándor - Izsák Lajos, 1977. 123.
} 
gyülekező helye". ${ }^{420}$ Külön örül Peyer és a polgári radikálisok kudarcának, ugyanakkor az FMDP viszonylagos sikerét - bekerülését a törvényhozásba - nem kommentálta a kommunista párt Politikai Bizottsága, amely egy ilyen tartalmú sajtónyilatkozatra kéri föl Rákosi Mátyás fötitkárt.

A koalíciós - pontosabban a választás szövetségben tömörült - pártok 1947 őszén petícióval fordultak az újonnan fölállított választási bírósághoz, amelyben azzal vádolták meg a Magyar Függetlenségi Párt vezetését, hogy nem eredeti aláírásokkal adta le az ajánlási íveket, így - mivel nem volt elegendő ajánlója - nem is indulhatott volna a választásokon. Ezzel párhuzamosan az ügyben az Országos Nemzeti Bizottság amely a politikai szervezetek választásokon való indulásáról döntött - is vizsgálatba kezdett. A Magyar Függetlenségi Párt a helyzet egyértelművé tételére új választás kiírását követelte. $^{421}$

Az Országos Nemzeti Bizottság 1947. november 19-én kimondta, hogy a Magyar Függetlenségi Párt indulását engedélyező határozatát - mivel az álláspontja szerint megtévesztésen alapult - megsemmisíti. Másnap a választási bíróság egyhangúlag hozott döntésével - amelyet az FMDP delegáltja is megszavazott megsemmisítette a párt mandátumait. Ezzel a kommunista párt megszabadult negyvenkilenc ellenzéki képviselőtől, semmibe véve hatszázötvenezer magyar választópolgár akaratát. Rajk László belügyminiszter november 20-án 547.995/1947. számú rendeletével föloszlatta a pártot. ${ }^{422}$

Az MKP Politikai Bizottságának a választásokat követő első ülésén már előkerült az MFP föloszlatásának ügye - igaz, akkor még csak fenyegetésként. Mint a testület 1947. szeptember 1-jei ülésének jegyzőkönyvében olvashatjuk: „Meg kell akadályozni, hogy a Kisgazdapárt jobbszárnya csatlakozzék Pfeifferékhez. Ezt a Kisgazdapárt baloldalának erősítésével és azzal a fenyegetéssel kell tenni, hogy a Pfeiffer pártot fel fogják oszlatni." ${ }^{423}$

Az 1947-es választások előkészületeinek idején és az azt követő rövid periódusban Balogh páter - pontosabban a Független Magyar Demokrata Párt - ismét megjelentette a Szegedi Napló címü újságot. A lap példányait a Szent Gellért Nyomdában készítették, ám Baloghék nem sokkal a választások után már szüneteltették

\footnotetext{
${ }^{420}$ PIL 274. 3/104. ö. e. 2-3.

${ }^{421}$ Ellenzék, 1947. október 4.

${ }^{422}$ Szerencsés Károly: Petíciós per. 1947. Valóság, 47 (2004). 12. sz. 43-49.

${ }^{423}$ PIL 274. f. 3/104. ö. e. 3.
} 
megjelentetését, ráadásul még a korábbi nyomdaköltségek egy részével is tartoztak. Ezért Vigyázó Rezső, a nyomda vezetője több szegedi vezető egyházi személynél köztük magánál a püspöknél - is járt arra kérve őket, bírják rá Baloghot a fizetésre.

Halász Pál apátkanonok, szeged-móravárosi plébánosnak - aki egyike volt a nyomdaszámla miatt a pátert figyelmeztetőknek - 1947. október 14-én írt Balogh István. Ebben egyrészt a számla mielőbbi kiegyenlítését ígérte, másrészt tájékoztatta paptársát arról, hogy a Szegedi Napló újbóli megjelentetése ismét napirenden van, mert - mint írta - tárgyalások folynak a Barankovics-párttal arra nézve, hogy ők támogatnak bennünket Szegeden, mi viszont őket támogatjuk egy Dunántúlon megindítandó lapjuknál."

Persze a tervből nem lett semmi. Barankovics és Balogh pártja ahogy más kérdésekben sem, úgy a közös sajtótermék kiadásának ügyében sem müködött együtt. Az adósságot azonban az FMDP továbbra sem rendezte, ezért Vigyázó Rezső Hamvas Endréhez fordult. 1948. február 16-án kelt levelében közölte föpásztorral, hogy nyomdája fizetésképtelen, ráadásul a papírhiány miatt nem tudja szerződéses munkáit sem teljesíteni, így nagy szüksége lenne a pénzre. Mivel azonban szerinte „Balogh államtitkár úr vagy egyáltalán nem akar fizetni, vagy csak megfelelő nyomás esetén”,424, arra kéri a püspököt, próbáljon meg hatni papjára.

Vigyázó Rezső leírta azokat a - más szinte tragikomikus helyzeteket teremtő kísérleteket is, hogyan próbált személyese kapcsolatba lépni Baloghgal. „Előbb a parlamentben kerestem, ahol bár tudomást szerzett arról, hogy személyesen keresem azzal tért ki a találkozás elől, hogy pártközi értekezlete van. Bár meg voltam győződve arról, hogy nem volt pártközi értekezlet és ez csak egy kifogás volt, hogy ne kelljen velem tárgyalnia, újra felhívtam a pártban lévő irodájában, ahol a titkár abbeli kérdésemre, hogy az államtitkár úrral szeretnék beszélni, azt a választ adta, hogy azonnal jelenteni fogja a szobájában tartózkodó képviselő úrnak, hogy beszélni óhajtok vele. Néhány perc múlva visszajött a titkár azzal, hogy bár korábban szobájában tartózkodott a képviselő úr, de az ő tudta nélkül időközben eltávozott onnan. Meg vagyok győződve arról, hogy ezen üzenet nem felelt meg a valóságnak, mert ahogy a helyszínt ismerem, onnan a titkár tudta nélkül nem távozhatott el, márpedig a titkár nekem úgy jelezte, hogy átadja a telefont a képviselő úrnak, mint aki tudja, hogy a képviselő úr a helyiségben tartózkodik. Ennek dacára is leadtam egy oly értelmü

\footnotetext{
${ }^{424}$ SZCSPL PHEI 488/1948.
} 
üzenetet az államtitkár úrnak, hogy a megadott telefonszámra leadandó üzenete esetén bármikor másnap is rendelkezésre állok, mint elöre látható volt, erre sem jelentkezett." $" 425$

Balogh páter 1948. február 17-én válaszolt a püspöknek, aki március11-i levelében már köszönetet mondott Baloghnak az ügy lezárásáért, hiszen - Vigyázó Rezső Hamvasnak adott tájékoztatása szerint - a nyomdaszámla ügye rendeződött.

Balogh István kapcsolata a csanádi egyházmegyével nem szakadt meg, hiszen titkára 1947. október 27-én huszonnyolc könyvet küldött a szegedi papnevelö szemináriumnak. A könyvek - magyar, latin és német nyelvü teológiai, liturgikus, hitbuzgalmi, illetve témájukban Szegedhez kapcsolódó kiadványok - ,az államtitkár úr könyvtárából valók” voltak. ${ }^{426}$ A köteteket Sopsich János prelátus, püspöki irodaigazgató 1947-én november 5-én levélben köszönte meg.

Rákosi Mátyás 1948. július 28-án tájékoztatta a Magyar Dolgozók Pártja Központi Vezetőségét Tildy Zoltán lemondásáról, valamint annak okáról (tudniillik, hogy veje - Csornoky Viktor kairói követ - az államvédelmi szervek koncepciós eljárásnak vádpontjai alapján valutaüzér, kém és hazaáruló). Az MDP vezető testülete Rákosi Mátyás előterjesztésére - a elkövetkező napokban döntött az új köztársasági elnök személyéről. Így Tildy 1948. július 31-i lemondásakor már tudni lehetett, hogy utódja Szakasits Árpád, az MDP elnöke lesz.

Nagy Imre, az országgyülés elnöke 1948. augusztus 1-jén délelőtt fél tízkor pártközi értekezletet tartott dolgozószobájában. A pártközi értekezlet először is tudomásul vette Tildy Zoltán lemondását, majd elfogadta Nagy Imre azon előterjesztését, hogy az új elnököt a legnagyobb kormánypárt, az MDP jelöli, amelynek személyi javaslatát a koalíciós pártok már meg is tárgyalták és el is fogadták.

Balogh István hozzászólásában a következőket mondta. „A Független Magyar Demokrata Párt elismeri a Magyar Dolgozók Pártjának azt a jogát, hogy a köztársaság elnöki tisztségére a maga soraiból állít jelöltet. Szavazás esetén pártja a Magyar Dolgozók Pártjának, mostmár a koalíciós pártoknak a jelöltjét támogatja szavazatával. Magáért a jelölésért azonban a felelősséget a Magyar Dolgozók Pártjának kell viselnie." $^{, 427}$

\footnotetext{
${ }^{425}$ SZCSPL PHEI 488/1948.

${ }^{426}$ SZCSPL PHEI 2795/1947.

${ }^{427}$ SZCSPL HBI 324.
} 
Az 1948. augusztus 1-jei pártközi értekezlet végén Rákosi azt javasolta, hogy a köztársasági elnök-jelölő íveket az ellenzéki pártok képviselői is írják alá. Két nappal később a magyar törvényhozás Szakasits Árpádot köztársasági elnökké választotta.

\section{2. A suspensio}

Balogh páter kapcsolata a magyar katolikus egyház fejével - mint már láthattuk - nem volt problémamentes. Balogh ugyanis szükebb, illetve tágabb körben - olykor a püspöki kar tagjainak is, például a vele jó kapcsolatban lévő Bánáss László veszprémi püspöknek, vagy Hamvas Endre csanádi püspöknek ${ }^{428}$ - többször és határozottan bírálta a bíborost. Úgy vélte ugyanis, hogy Mindszenty nyíltan vállalt és gesztusokkal is kifejezett intranzigens konzervatív és legitimista meggyőződése nemcsak neki, de az egész magyar katolicizmus számára nehézségeket okozhat.

Balogh politikai tevékenységét egyébként egyházi elöljárói - így még a Horthykorszakban Glattfelder Gyula, később Hamvas Endre csanádi püspök, illetve maga a hercegprímás - mindig is gyanakvással és bizalmatlansággal figyelték. Ennek ellenére az alsópapság és bizonyos szerzetesrendek - így a ferencesek és a piaristák, illetve a női rendek vezetői - kifejezetten jó kapcsolatot tartottak fönn vele a koalíciós években. Ennek egyszerü oka volt: a kiépülő diktatúra egyházellenes politikájának első áldozatai közülük kerültek ki, s közbejárásért, ügyük elintézéséért számos esetben fordultak a miniszterelnöki hivatalt vezető páterhez.

1948 nyarára - az egyre keményedő Mindszenty-ellenes politikai támadások két éve és az egyházi iskolák államosítása után - a hercegprímás úgy döntött, egyházi fenyíték - papi tevékenységének fölfüggesztése - kilátásba helyezésével eltiltja a politikai és közéleti tevékenységtöl Baloghot. Erről a pátert közvetlen ordináriusa, Hamvas Endre tájékoztatta 1948. június 25-én szóban, majd június 30-án írásban kérve, hogy ne szerepeljen politikai tömegrendezvényeken, ne nyilatkozzon a sajtónak, s a befolyása alatt lévő médiumokkal is szakítsa meg a közvetlen kapcsolatot. ${ }^{429}$

\footnotetext{
${ }^{428} \mathrm{BIV}$

${ }^{429}$ Haas György, 2010. 138-150.
} 
Balogh István ennek hatására megritkította politikai szerepléseit és kis időre visszavonult a nyilvánosságtól. Parlamenti mandátumáról és pártelnöki tisztségéről azonban nem mondott le, s ezek hiányában a csanádi püspök 1948. augusztus 17-én kimondta a suspensiot.

Balogh, amint erröl értesült, levelet írt főpásztorának, amelyben kifejtette, hogy 1948 júliusa óta a sajtóval való kapcsolatait fölszámolta, s azóta politikai jellegü rendezvényeken sem vett részt. Leírta továbbá, hogy a Független Magyar Demokrata Párt napi ügyvitelében sem vesz részt és hogy augusztus eleje óta szabadságon van, tehát - véli - nem szegült ellen a püspöki utasításnak.

Mint Balogh írta: „Augusztus 4-én szabadságra mentem, amiről a sajtó is megemlékezett. A párt vezetését távollétem idejére Parragi György vette át, a képviselőcsoportot, amint azt az azóta kiadott kommünikék is igazolják, P. Ábrahám Dezső vezeti. Semmiféle nyilvános politikai tevékenységet tehát nem fejtettem és nem fejtek ki, mert mindennél fontosabbnak tartom, hogy Ordináriusommal való viszonyom továbbra is rendezett maradjon., ${ }^{430}$

Hamvas Endre erre reagálva közölte Balogh páterrel, hogy „a politikai szereplés megszüntetése alatt a képviselői mandátumról való lemondás is értendő." ${ }^{431}$ Hozzátéve: „Szívesen várom vissza az egyházmegyébe is, ha szolgálatot vállalni kíván. Meg vagyok győződve, hogy itt még sok jót tehet Egyházáért, hazánkért, míg politikai pályán ennek lehetőségét nem látom. Felhívom arra is figyelmét, hogy e nehéz időkben Egyházunkat mily mértékben dicsőíti és erősíti tiszteletreméltó fegyelme." ${ }^{432}$

Balogh 1948. augusztusi fölfüggesztésére - a nyilvános papi müködésétől való eltiltásra - és az azzal kapcsolatos egyházi elöljárójával kialakult polémiájára később a következőképpen emlékezett. „Felfüggesztésem is tipikus Mindszenty-eljárás. Soha semmiféle formában nem hallgattak meg. Mindszenty azt hitte, hogy sérthetetlen. Nemsokára jön az atombomba, de az csak az itteni kommunistákat fogja eltalálni. Abban a gondolatkörben mozgott, amelynek szemlélete uralta egyéniségét, mielőtt veszprémi püspök lett. Amikor például Zalaegerszegen elmozdította a protestáns

\footnotetext{
430 ÁBTL Balogh István objektum dossziéja. 3.1.5. O - 10973. (a továbbiakban: 3.1.5. O - 10973) $142 / 24$.

${ }^{431}$ ÁBTL 3.1.5. O - 10973. 142/26.

${ }^{432}$ ÁBTL 3.1.5. O - 10973. 142/26.
} 
alispánt. ${ }^{433}$ Akkor ez nagy feltünést keltett. Sokan a katolikus kiállás mintáját látták az ilyen ténykedésben. Ma elviselhetetlen lenne az ilyen viselkedés. 1946-ban semmit sem értett meg abból, hogy hiába hangoztatja zászlósúri címét ${ }^{434}$, ez senkire nem hat. ${ } 435$

Miután valamennyi országos politikai hírlap közölte Balogh István fölfüggesztését, a páter a Magyar Nemzetben 1948 őszén ötrészes cikksorozatot közölt, amelyben bizonyítani próbálta annak indokolatlanságát, valamint kifejtette saját egyházpolitikai nézeteit. ${ }^{436}$ A sorozatot Reálpolitika az egyház és az állam viszonyában címmel önálló kötetben is megjelentette.

Cikkeiben Balogh ironikus és érezhetően sértődött hangnemben azt írta, hogy a fölfüggesztés miatt nem egyházi elöljáróit hibáztatja, hanem saját magát vádolja. Valójában azonban érdemeit sorolta: a Délmagyarországnak, mint demokratikus szellemiségü lapnak a megindítását; a Magyar Nemzeti Függetlenségi Front szegedi létrehozását; az Ideigenes Nemzetgyülés politikai bizottságának előadójaként a veszprémi és a székesfehérvári püspöki birtokoknak a szétosztás alóli mentesítésében való szerepvállalását; a kormány előtti kiállását Mindszenty József érseki kinevezésekor stb. Ez utóbbiról az alábbiakat írta.

„1945 márciusában, tehát még a háború befejezése előtt az ellenőrző bizottság távozásra szólította fel a még Budapesten tartózkodó és a Szálasi-kormánynál akkreditál idegen követségeket. Így Angelo Rotta pápai nunciust is. Intervenciómra, melyet később Miklós Béla miniszterelnök is személyesen támogatott sikerült - sajnos, csak néhány hétre - a pápai nuncius elutazásának idejét kitolni.

Azóta nincs a Vatikánnak közvetlen összeköttetése a magyar kormánynak. Ez az oka például, hogy az esztergomi érseki szék betöltésénél a magyar kormány kívánságai nem voltak figyelembe vehetők. Az ideiglenes nemzeti kormány Mindszenty József akkor veszprémi püspöknek esztergomi érsekké, tehát Magyarország hercegprímásává

\footnotetext{
433 A zalaegerszegi református főispán Teleki Béla gróf (1896-1969) volt. Vö. Balogh Margit: Mindszenty József. Budapest, 2002. 34.

434 Vö. Balogh Margit: Mindszenty József prímás-érsek és az államforma kérdése 1945-1946-ban. Magyar Egyháztörténeti Vázlatok, 22. (2010) 3-4. sz. 111-126.

${ }^{435}$ Haas György, 2010. 140-141.

436 A cikksorozatra az Új Ember is reagált (1948. november 14.), s fölhívta olvasói figyelmét arra, hogy Balogh páter „,egyházával szemben engedetlen”, ezért „nem alkalmas egyházpolitikai kérdések érdembeli megvitatására és orvoslására”. Idézi: Szeghalmi Elemér: Keresztény küzdelmek és megtorpanások. Az Új Ember 1945-1956 között. Budapest, 2000. 62.
} 
történt kinevetése ellen állást kívánt foglalni. ${ }^{437}$ Vádolom magam azzal, hogy sikerült nekem a minisztertanácsban Mindszenty József személye iránt bizalmat kelteni és egy kultúrharc lehetőségét akkor még csírájában elfojtani." "438

Balogh a katolikus álláspontnak a társadalmi nyilvánosság előtti megjelenítését elösegítő müködését is ismertette. Leírta, hogy a sajtóügyekért is felelős miniszterelnökségi államtitkárként már Debrecenben - a kormány ott tartózkodása idején - lapengedélyt adott a csanádi egyházmegye Hitvallás címü hitbuzgalmi kiadványának $^{439}$, később pedig a Vigilia, a Szív és az Új Ember című katolikus újságoknak.

Balogh szerint a „demokratikus állam” és azzal folytatandó párbeszéd elutasítása veszélyezteti a katolikus szellemü oktatás és papnevelés ügyét, valamint csorbíthatja a katolikus hívek vallásuk szabad gyakorlásához való jogát. Mint megfogalmazta: „A magyar katolicizmus tehát zsákutcába jutott. Nem ült le a tárgyalóasztalhoz, amikor az új tankönyvekről volt szó és a non possumus ${ }^{440}$ álláspontjára helyezkedett az iskolák államosításával kapcsolatban felmerült kérdésekben.

Azóta már meg is jelentek a tankönyvek anélkül, hogy az egyház befolyással lehetett volna azok szerkesztésére és szeptember elseje óta folyik a tanítás az össze magyar iskolában, azokban a katolikus iskolákban is, amelyeket az állam - amint a reformátusok és evangélikusok iskoláival is tette - a katolikus egyház kezén hagyott volna. A különböző felekezetek képviselői és a kormány képviseletében Ortutay Gyula már aláírták azóta a szerződéseket, melyek részint biztosítják a felekezeteknek a vallás szabad gyakorlatával, a hitoktatással, a papneveléssel kapcsolatos jogait, valamint az

\footnotetext{
${ }^{437}$ Az Ideiglenes Nemzeti Kormány 1945. május 25-i ülésén hat egyházi személy merült föl a kabinet javaslataként a Serédi Jusztinián halálával megürült esztergomi érseki szék betöltésére: Bánáss László debreceni prépost, nemzetgyülési képviselő, Márton Áron gyulafehérvári püspök, Grősz József kalocsai érsek, Czapik Gyula egri érsek, Mindszenty József veszprémi püspök, valamint Kelemen Krizosztom pannonhalmi föapát. Végül a kormány Bánáss Lászlót, Márton Áront és Kelemen Krizosztomot ajánlotta az Apostoli Szentszéknek. XII. Pius pápa azonban Mindszentyt nevezte ki, s döntését Miklós Béla kormánya 1945. szeptember 17-i ülésén tudomásul is vette. Vö. Dálnoki Miklós Béla kormányának (Ideiglenes Nemzeti Kormány) minisztertanácsi jegyzökönyvei. 1944. december 23. - 1945. november 15. Szerk., bev., jegyz.: Szűcs László. Budapest, 1997. A. köt. 30. és B. köt. 207.

${ }^{438}$ Balogh István: Reálpolitika az egyház és az állam viszonyában. Budapest, 1948. (a továbbiakban: Balogh István, 1948) 7.

${ }^{439}$ Vö. Pál József: A Hitvallás története. Szegedi Könyvtári Mühely, 26-28 (1987-89). 1-4. sz. 80-115.

${ }^{440}$ Non possomus! = Nem tehetjük! (latin)
} 
államnak a velük szemben vállalt kötelezettségeit. A katolikus egyháznak sem jogai, sem az államnak vele szemben esetleges kötelezettségei még nem voltak megegyezés tárgyai, így azok a levegőben lógnak, minden pillanatban lehetséges változásnak kitéve.

Érezzük mindannyian, hogy ez az állapot veszedelmes, ezért tarthatatlan. A zsákutcából ki kell jutnunk, mégpedig sürgősen, sőt ha kell - sohasem elvi - áldozatok árán is." $" 441$

Az egyházi fenyítékbe Balogh István nem törődött bele, ezért az ellen fellebbezést nyújtott be az Apostoli Szentszék illetékes szervéhez, a Szent Officiumhoz (Sacra Congregatio Sancti Officii), a mai Hittani Kongregáció (Congregatio de Doctrina Fidei) elődjéhez.

Balogh fellebbezését 1950. június 7-én vonta vissza. Addigra már a Rákosidiktatúra kiépült, Mindszenty Józsefet letartóztatták, elítélték és bebörtönözték - ezzel példátlanul brutális módon eltávolították a közéletből -, s közelinek tünt a kommunista állam és a magyar katolikus egyház közötti megállapodás megkötése. Erről tájékoztatta Hamvas Endrét is, akit - miközben rábízta az erről szóló dokumentum Rómába való közvetítését -, arra kért, revideálja a fölfüggesztéséről szóló rendelkezést, hogy legalább lehetősége legyen szentmise bemutatására.

„Püspök úr előtt, mint Ordináriusom elött - írta Balogh páter -, fel kell tárnom azt is, hogy amikor a Hercegprímás úr a politikai szerepléstől való visszavonulásra felszólított, könnyen engedelmeskedhettem volna, ha csak a magam egyéni szempontjait mérlegelem, de tisztában voltam azzal a bonyodalommal, amit egy politikai párt feloszlatásával a rendelkezés közvetve eredményezett volna. Ez ugyanis a magyar belpolitikába való olyan beavatkozásnak tünt volna fel, amely súlyos visszahatást váltott volna ki. Fellebbezésem ezeket a bonyodalmakat minden bizonnyal elhárította.

Amikor Kegyelmes Urat fellebbezésem visszavonó iratának továbbítására felkérem, szeretném megkérni, hogy felfüggesztésemet tartalmazó rendelkezését revízió alá venni szíveskedjék és jószándékom, valamint készségem figyelembe vételével módosítani méltóztassék annyira, hogy a misézés tekintetében némi enyhülés következnék be." ${ }^{442}$

\footnotetext{
${ }^{441}$ Balogh István, 1948. 22.

${ }^{442}$ ÁBTL 3.1.5. O - 10973. 142/46.
} 
Hamvas Endre püspök csak egy esztendővel később, 1951. június 25-én oldotta fel a suspensiot, mivel - indoklása szerint - a fölfüggesztést kiváltó okok megszüntek. Ez így is volt, hiszen Balogh 1951. június 8-án - külső nyomásra, hiszen addigra már túl volt egy rövid államvédelmi őrizeten - lemondott parlamenti mandátumáról és visszavonult a közélettől.

\section{3. Az állam és egyház közötti megegyezés sürgetése, a politikai karrier vége}

1949 tavaszán az Isteni Szeretet Leányai rákospalotai közössége fordult Balogh Istvánhoz. Ottani elemi iskolájukat ugyanis államosították, s a nővérek az általuk lakott Kossuth utcai 41. szám alatti ház átadására is fölszólítást kaptak Horváth Károlytól, a Vallás- és Közoktatásügyi Minisztérium osztálytanácsosától. Az ügyben Balogh páter fölháborodottan írt Ortutaynak 1949. április 23-án.

„A szóban forgó épület nem tekinthető tanítói illetménylakásnak. Valamikor plébánia volt, később pedig, mikor a plébánia másik épületben nyert elhelyezést, ide költöztek a nővérek, akik mellékesen tanítással is foglalkoztak. Ez tehát nem tekinthető illetménylakásnak, mert akkor is ott laknának, ha nem tanítottak volna, és ha egy ügyosztály így értelmezi az ide vonatkozó rendelkezéseket, akkor az összes tanítással foglalkozó szerzeteseknek el kellene hagyniok rendházaikat, mert hiszen valahol lakniok kellet úgyis, mint apácáknak, úgyis mint tanítónőknek. Mindenütt, ahol komolyan vették a rendelkezést és nem vittek indulatot annak végrehajtásába, mint úgy látszik, Rákospalotán, korrektül jártak el.

Nagyon nehéz az én helyzetem, amikor az egyházi körök és hívek bizalmát és jóindulatát meg akarom nyerni, akkor számtalan esetbe ilyen politikai szarkatestvéreknek önkényeskedésével kellett találkoznom és minisztereket, mint most Téged is az igazság és jogrend érdekében zaklatnom. Ne vedd rossz néven kitörésemet, de úgy érzem, régi barátságunk címén egymással szemben ezt megengedhetjük."443

${ }^{443}$ SZCSPL HBI 421. 
Balogh 1949. június 3-án örömmel jelentette az egykori parasztpárti Donáth Ferencnek - aki akkor Magyar Dolgozók Pártja Központi Vezetőségének tagja, az Országos Földbirtokrendező Tanács elnökhelyettese volt -, hogy tudomására jutott: vidéken számos falusi katolikus pap agitál a szövetkezetesítés mellett. Június 7-én kelt válaszában Donáth nem osztozott Balogh örömében, mivel az MDP vezetésében az az álláspont alakult ki, hogy „ez ilyen formában nem célravezető. A falusi papságnak a szövetkezetes szervezésében való aktív részvétele elkerülhetetlenül oda vezetne, hogy a falusi reakció e szervezkedés mögé állana, ami másrészt azt jelentené, hogy a falu demokrata elemei viszont távol maradnának. Megjegyzem, természetesen változatlanul helyesnek és kívánatosnak tartjuk, hogy a falvak papjai a nép demokrácia és ezen belül a szövetkezeti kérdéshez, prédikációikban, pozitívan foglaljanak állást."

Balogh Istvánt 1949 májusában értesítették arról, hogy a Közületeket Elhelyező Bizottság a budapesti rózsadombi Krisztus Király Lelkészég „összes helyiségeit igénybe kívánja venni” az iparügyi minisztérium megbízásából.

Emiatt a páter 1949. május 31-én írt Kossa István iparügyi miniszternek: „Meg vagy győződve róla, hogy erről sem Magad, sem bármilyen politikai tényező kellő információt nem szerzett, mielőtt ez a rendelet kiment volna. Nemcsak arról van szó, hogy egy müködő lelkészséget akar megszüntetni rendelet, hanem egy kápolnát is igénybe akar venni világi célokra. Ez olyan precedens volna, amely éles ellentétben állana azzal a hangulattal, mely a püspöki karnak a választásokkal kapcsolatban kiadott körlevele óta, illetve Rákosi Mátyásnak Celldömölkön elmondott beszéde óta örvendetesen kialakulóban van. Nagyon kérlek, légy szíves az ügyet sürgősen megvizsgáltatni és a rendelkezést felfüggeszteni." 445

Kossa István egy héttel később válaszolt Baloghnak - igaz, a „Kedves Barátom!” megszólítású levelét, „Balogh István úrnak, a Polgári Demokrata Párt elnökének” címezte - amelyben így közölte, hogy az ügyet leállította. „Hozzám intézett legutóbbi leveledben foglaltak ügyében - amint azt már közben tapasztaltad közbeléptem és az egész ügyet leállítottam. Ki kívánom hangsúlyozni, hogy az ügyről előzetes tudomásom nem volt.",446

\footnotetext{
${ }^{444}$ SZCSPL HBI 471.

${ }^{445}$ SZCSPL HBI 469.

${ }^{446}$ SZCSPL HBI 469.
} 
1949. május 27-én Balogh Rákosi Mátyásnak - aki akkor a Magyar Függetlenségi Népfront elnöke és miniszterelnök-helyettes volt - írt, amelyben az alábbiakat fogalmazta meg.

„A püspöki karnak a május 15-i választásokkal kapcsolatban kiadott körlevele, illetőleg a celldömölki beszédedben arra adott válaszod egy kibontakozási lehetőség reményét keltette a legszélesebb körökben.”447 Ezekre alapozva - írta Balogh megmozdult a katolikus közvélemény és mind az alsópapság, mind a hívek köréböl sokan keresik föl a politikai és egyházi vezetöket - köztük öt magát is -, és sürgetik az állam és az egyház közötti mielőbbi megegyezést.

Balogh javasolta Rákosinak egy hattagú a kormány és a püspöki kar három három képviselőjéből álló bizottság fölállítását, amely kidolgozna egy olyan megállapodást, ami minden olyan témát fölölel, amelyet a magyar katolikus püspöki kar az Apostoli Szentszék engedélye vagy fölhatalmazása alapján tárgyalhat. Természetesen a „tárgyalások előkészítésének munkáját” Balogh magára vállalta volna.

„E bizottság - írta Rákosinak - két hét alatt elvégezhetné feladatát és napokon belül összeülhetne maga a kormány a püspöki karral. A megegyezés a kormány és a magyar katolikus egyház között olyan légkört teremtene, amely alkalmas lehetne arra, hogy a kormány a Mindszenty-kérdést likvidálhassa. Ha ez is megtörtént, semmi állná útját annak, hogy egy végleges megállapodást köthetne egyház és állam olyan kérdések tekintetében, amelyekre vonatkozó döntés a Vatikánt illeti."

Balogh páter mind Kossának, mind Rákosinak írt levelében hivatkozott a Magyar Dolgozók Pártja főtitkárának celldömölki beszédére. Rákosi Mátyás a Magyar Függetlenségi Népfront 1949. május 8-i Celldömölkön tartott választási nagygyülésén elmondott beszéde záró egységének első gondolatai a következők voltak.

„Összefoglalva: mi a béke katonái vagyunk és folytatni akarjuk azt a politikát, amely sokat szenvedett népünk számára biztosítja a teremtő békét. Május 15-én a magyar dolgozó nép ebben a kérdésben is állást foglal és állásfoglalása számunkra nem kétséges. A munkások és parasztok azokat fogják támogatni, akik a béke frontján küzdenek.

Befejezésül vessünk egy tekintetet magára a Magyar Függetlenségi Népfrontra. Ez a Népfront öt politikai pártnak és a hatalmas demokratikus tömegszervezeteknek a

\footnotetext{
${ }^{447}$ SZCSPL HBI 468.

${ }^{448}$ SZCSPL HBI 468.
} 
szövetsége. Élén áll és vezeti a Magyar Dolgozók Pártja. Ez a Párt a szövetséges Független Kisgazdapárttal, Nemzeti Parasztpárttal, a Balogh-párttal és radikálisokkal együtt az 1947-es választásokon az összes szavazatok 68 százalékát kapta.

A demokrácia azóta hatalmasan megnövekedett. Ennek egyik jele éppen az, hogy a Balogh-párt, amely két évvel ezelőtt még ellenzéki volt, jó munkánk és helyes utunk felismeréseképpen belépett a kormánypártok közé. Mindenki tudja saját tapasztalatából, hogy a Barankovics-pártnak sok tízezer szavazója, aki két évvel ezelőtt szemben állt velünk, vagy kételkedett utunk helyességében és ezért nem ránk szavazott, ma már megváltoztatta magatartását és átjött a demokrácia oldalára.

Legjobban mutatja ezt a hangulatváltozást a magyar egyházak magatartása. A protestáns egyházak tudvalevőleg felhívták híveiket, hogy a választáson szavazzanak a Népfrontra. És két nappal ezelött a magyar római katolikus egyház püspökei is hasonló szellemben nyilatkoztak.

Üdvözöljük a római katolikus püspöki kar állásfoglalását, mint az első komoly pozitív lépést abban az irányban, hogy egészségesen megoldjuk a demokrácia és az egyház viszonyát. Most már csak az kell, hogy ezt az első lépést újabbak kövessék, hogy ne álljanak meg félúton, hanem menjenek tovább. Ezt várja tőlük az egész magyar demokrácia és benne a katolikus dolgozók is."449

A Rákositól idézett beszédrészlet egyik nagy tanulsága, hogy Balogh István Független Magyar Demokrata Pártját kvázi a koalícióhoz - az 1947-es választási szövetség pártjai közé - sorolja, sőt ki is mondja, hogy a páter által vezetett szervezet noha erre hivatalosan soha nem került sor - „belépett a kormánypártok közé”. A másik kiemelendő elem, hogy Rákosi - Mindszenty és az általa képviselt sajátos konzervativizmus ${ }^{450}$ politikai térből való kiszorítása után - sürgette a pártállam és a katolikus egyház közötti formális megegyezés létrejöttét is. Balogh ez utóbbira reagált föntebb idézett levelében.

\footnotetext{
449 Rákosi Mátyás: Május 15-én egy emberként a Népfront mellé! A Népfront választási gyülésén, Celldömölkön 1949. május 8-án mondott beszéd. In: Uő: A békéért és a szocializmus építéséért. Budapest, 1951. 24-25.

${ }^{450}$ Vö. Bauquet, Nicolas: A Mindszentyzmus. In: A magyar jobboldali hagyomány. 1900-1948. Szerk. Romsics Ignác. Budapest, 2009. 534-555.
} 
Az 1948 vége és 1950 nyara között a katolikus püspökök és a kormány között folyó tárgyalásokon - noha nagyon szeretett volna - Balogh nem volt jelen. ${ }^{451} \mathrm{~A}$ háttérből viszont bábáskodott a megállapodás létrejöttén: több egyházi vezetőt bíztatott a tárgyalásokon való részvételre, illetve azok mielőbbi sikeres lezárására. Így például Grősz József kalocsai érseket, Hamvas Endre csanádi püspököt ${ }^{452}$, vagy Endrédy Vendel zirci ciszterci apátot.

Endrédy 1949. május 3-án magához invitálta Balogh páter, amikor is több mint kétórás megbeszélést folytattak. A zirci apát elmondta, hogy „a hercegprímás úr édesanyjának fiánál tett látogatásáról ${ }^{453}$, mely február végén történt $\mathrm{s}$ amelynek lefolyásáról pontos információja volt, alkalmi futár útján Rómába jelentést tett. A jelentés nagy megnyugvást keltett." ${ }^{, 454}$

A megbeszélés során Endrédy tájékoztatta Baloghot, hogy a püspöki kar számos tagja hajlandóságot mutat az állammal való tárgyalások folytatására, illetve megállapodás esetleges megkötésére. „Ami a püspöki kar állásfoglalását illeti a mostani választásokkal kapcsolatban, úgy tudja, már több püspök utasítást adott a lelkészkedő papságnak, hogy bár aktív politikai tevékenységet nem fejthetnek ki, a Népfrontot támogassák, a Népfront ellen még bizalmas körben is tilos bármilyen állásfoglalás, a szavazásban való részvételt, mint állampolgári kötelességet ugyancsak előírják. ${ }^{455}$ Vélemény szerint a hívek túlnyomó többségben követni fogják papjaik példáját" ${ }^{\text {"45 }}$ jegyezte föl Balogh.

Balogh István 1945 elejétől megbízható szövetségese és barátja volt Kunszery Gyula (1906-1973), aki elöbb a miniszterelnökségen volt sajtóreferens, majd a páter lapjainál - Magyar Nemzet, Mai Nap, Szabad Száj - dolgozott szerkesztőként, illetve

\footnotetext{
451 Az állam és egyház közötti 1950. augusztus 30-i megállapodást megelőző tárgyalásokról: Gergely Jenő: Az 1950-es egyezmény és a szerzetesrendek feloszlatása Magyarországon. Dokumentumok. Budapest, 1990. 23-329.

${ }^{452}$ SZCSPL PHEI 80/1949.

${ }^{453}$ Mindszenty József édesanyja Kovács Borbála volt.

454 SZCSPL HBI 423.

455 Hogy ezt az alsópapság aztán mennyire elfogadta, arra példa Tóth Péter tiszaszigeti plébános följegyzése 1949-ből: „Május 15-én az ország népe képviselőket választott. Megújult az országgyülés, a törvényhozás testülete. A nép döntött sorsuk felöl. A »Népfront« nálunk is a szavazatok 98 százalékát kapta. Mindenesetre meglepő eredmény itt, ahol az ellenzék közismerten erős, mondhatnám hajlíthatatlan. Az idők jele!” A tiszaszigeti plébánia Historia domusa. 1. köt. (1918-1976).

${ }^{456}$ SZCSPL HBI 423.
} 
újságíróként. A publicisztika mellett költőként (kötetéről még Radnóti Miklós írt méltatást a Nyugat 1938. évi kilencedik számában) és irodalomtörténészként is alkotó Kunszery 1945-ben a Magyar Radikális Párthoz csatlakozott, annak volt delegáltja a Budapesti Nemzeti Bizottságban. 1947-ben azonban átlépett az újonnan alakult Baloghpártba és annak lett országgyülési képviselője. 1949. március 8-án lemondott mandátumáról, majd különbözö iskolákban dolgozott adminisztrátorként, írásait pedig kizárólag a katolikus lapok közölték.

A katolikus elkötelezettségét vállaló és hangoztató, ugyanakkor a kormányt és a politikus szatirikus versikékben bíráló Kunszery lemondását egyezség előzte meg. Balogh az kérte Ortutaytól, hogy Kunszery lemondása után kerüljön ismét a Vallás- és Közoktatásügyi Minisztériumba (ahol korábban tanártovábbképző tanfolyamok szervezője, illetve előadója volt). Mivel azonban a lemondása után két hónappal sem kapott állást a minisztériumban, Balogh írásban emlékeztette Ortutay Gyulát megállapodásukra. ${ }^{457}$

Ortutay 1949. május 18-i - „Kedves Pista Bátyám!” megszólítással induló válaszában a nyugdíjazást ajánlotta föl. „Kunszery ügyét megvizsgáltattam és tekintettel személyes pártfogásodra, végelbánás, illetőleg rendelkezései állományba való helyezés helyett nyugdíjazását rendeltem el. Ez a maximum, amit érdekében tehettünk, ezt is csak azért, mert támadásai miatt nem akarom, hogy úgy tünnék fel, mintha bosszút állnék rajta, viszont politikai magatartása lehetetlenné teszi újból való beosztását. Ezért a számára lehetséges legkedvezőbb módot, a nyugdíjazást engedélyeztem."458

1949. június 3-án Balogh ismét Ortutayhoz fordult. „Engedd meg, - írta Balogh - hogy szíves figyelmedbe ajánljam dr. Rogács Ferenc pécsi segédpüspök úrnak fizetési ügyét. A püspök úr ma is mint a szombathelyi egyházmegye nagyprépostja kap tiszteletdíjat, elvonva szombathelyi egyházmegyétől, amely mert számára, mint pécsi püspök számára fizetés kiutalva nincs. Azt hiszem, az ügy annyira jelentéktelen, hiszen csak 150-200 forinttal haladhatja meg a segédpüspöki fizetés a nagyprépostét, hogy a kérdés elintézése bizonyára nem fog nehézségbe ütközni. Rogács püspök úr személyében és magatartásában olyan, aki a kormánynak erre a csekély baráti gesztusára bizonyára érdemes." ${ }^{459}$

\footnotetext{
${ }^{457}$ SZCSPL HBI 444.

458 SZCSPL HBI 452.

${ }^{459}$ SZCSPL HBI 472.
} 
Ortutay Gyula vallás- és közoktatásügyi miniszter 1949. június 14-én írt válaszában a következőket fogalmazta meg: „Dr. Ragács Ferenc pécsi segédpüspök fizetésével kapcsolatos leveledre válaszolva értesítelek, hogy a segédpüspöki fizetést elvi okokból nem folyósíthatjuk. Dr. Rogács Ferencet ugyanis utódlási joggal a Vatikán nevezte ki, anélkül, hogy ehhez a kormány hozzájárulását kérte volna. Fizetése folyósítása tehát a Vatikán eljárásának elismerését jelentené és nem kívánatos precedenst szolgáltatna." ${ }^{460}$

Rogács Ferencet (1880-1961) XII. Pius pápa 1948. május 20-án nevezte ki címzetes sebasteni püspökké és utódlási joggal segédpüspökké a pécsi egyházmegyébe, amelynek vezetését Virág Ferenc (1869-1958) halála után 1958 márciusában át is vette.

Balogh István a ferences renddel különösen jó kapcsolatban volt az 1940-es évektől egészen haláláig. A ferencesek 1948 és 1951 között, papi szolgálatának egyházi fölfüggesztése idején is szeretettel fogadták, s élete végén is gyakran keresett náluk menedéket és megnyugvást. Nem véletlen, hogy végrendelete néhány passzusának végrehajtását is Szent Ferenc rendjének magyarországi tartományfőnökére bízta, ahogy az sem, hogy a lelki üdvéért bemutatandó szentmisék elvégzésére is őket kérte föl.

Éppen emiatt a - vélhetően spirituális gyökerekkel rendelkező - szoros kapcsolat miatt többször közvetítette a ferencesek - például Király Anaklét 1947 és 1957 közötti provinciális, vagy Gábris Grácián - ügyeit Ortutay felé. 1949. május 26-án azonban a kultuszminiszter elutasította Balogh közbenjáró kérelmét a következő indoklással: „Tájékoztatásodraözlöm, hogy a ferencrendi szerzeteseknek hozzám beadott kérvényét aláírójával kapcsolatban az I. ü[gy]. o[sztály]. a következőket közli: »P[áter]. Gábris Grácián szentferencrendi /Bp. II. Mártírok útja 23./ plébános többoldalról beszerzett bizalmas értesüléseim szerint a legvadabb fasiszta, aki saját kijelentései szerint, pap létére a közeljövőben remélt rendszerváltozás után sajátkezűleg akarja a kommunistákat akasztani. - A múlt héten jelentette ki nagyobb papi társaságban, hogy Révai ott van, ahová való: a bolondokházában. « Nem hinném, hogy ezután alapja lenne bármiféle támogatásodnak."461

Balogh a hozzá segítségért fordulók érdekében továbbra is folytatta közbenjáró tevékenységét. 1949 októberében a rendőrség által őrizetbe vett és eljárás alá vont Kasza Sándor ügyében fordult a belügyminisztériumhoz. Levelére Zöld Sándor belügyi

\footnotetext{
${ }^{460}$ SZCSPL HBI 485.

${ }^{461}$ SZCSPL HBI 460.
} 
államtitkár - ugyan „Kedves Barátom!” megszólítással - határozott hangnemben válaszolt 1949. október 31-én.

„Kasza Sándor ügyében szerveink a vizsgálatot lefolytatták. Az adatok alapján megállapítottuk, hogy a Kasza elleni eljárás minden részében indokolt s leveled állításai nem fedik a valóságot, s így felehető, hogy félrevezettek, de Te Kádár miniszter úrnak megígérted, hogy csak erősen megalapozott kéréssel fordulsz hozzá. Kasza Sándor ügye nem ilyen. A hasonló természetű beadványai erősen megnehezítik azt, hogy ügyeid iránt a kellő bizalom kialakulhasson., ${ }^{462}$

A „Szívélyes barátsággal köszönt: Zöld Sándor” befejező formulával záruló levél rámutat arra, hogy Balogh még a politikai pluralizmus fölszámolása után is - mint országgyülési képviselő és mint az elnöki tanács tagja - rendelkezett bizonyos politikai befolyással és kapcsolatrendszerrel. Természetesen érdekérvényesítő képessége már messze nem volt olyan nagy, mint államtitkár korában. A hivatalos politikai funkciói mellett korábbi - 1944 novembere óta gyarapodó - ismeretségei, személyes, emberi - és számos esetben kifejezetten baráti - kapcsolatai s segítették abban, hogy segítségére legyen a hozzá fordulóknak.

Az elnöki tanács 1949. november 14-i ülésén Olt Károly ismertette a mütárgyak bejelentési kötelezettségéről szóló törvényerejü rendelet javaslatát. Az ülésen résztvevő Balogh István hozzászólásáról - amelyért Ortutay Gyula vallás- és közoktatási miniszter még aznap köszönetet mondott - feljegyzés is készült.

„Helyesnek tartom - fogalmazott a páter -, hogy ezen a téren a kormány rendet teremteni próbál. Bár a javaslat nem tökéletes, mégis lépést jelent a rend felé. Ezért a javaslatot elfogadom. van azonban két észrevételem. Az egyik az, hogy a javaslat nem tesz említést egyházi múzeumokról. Ez bizonyára azt jelenti, hogy az egyházi múzeumok eddigi jellegét nem akarja megszüntetni, és annak anyaga továbbra is zavartalanul az egyház tulajdonában marad.

A másik észrevételem inkább kérés jellegü, a 12. §-ra vonatkozik. Ez a paragrafus megengedi, hogy rokonok bizonyos határon belül egymásnak ajándékozhassanak mütárgyakat. Ezt a jogot kérem az egyház javára is. Magam is eddig több mütárgyat ajándékoztam egyházi intézményeknek. Ha alkalmam és módom lesz,

${ }^{462}$ SZCSPL HBI 614. 
ezt a jövőben is szívesen megtenném és megteszik bizonyára majd mások is, ne legyen ennek akadálya, hanem az egyházat illesse meg a közeli rokon joga.”463

A jogszabályt elfogadta a Népköztársaság Elnöki Tanácsa, s az két nappal később - november 16-án - mint a múzeumokról és müemlékekről szóló 1949. évi 13. számú törvényerejü rendelet került kihirdetésre és lépett hatályba. Ez - az egyházi gyüjtemények és a magántulajdonban lévő mügyüjtemények kivételével - minden múzeumot államosított és központi irányítás alá szervezett, ugyanakkor elrendelte a magángyüjtemények nyilvántartásba vételét is.

1950. január 6-án déli tizenkét órakor Balogh István látogatást tett Farkas Mihály honvédelmi miniszternél, a Magyar Dolgozók Pártja főtitkár-helyettesénél. Balogh páter beszélt a Rajk-per belpolitikai következményeiről, valamint az állam és az egyházak közötti viszony kapcsán az ország politikai megosztottságáról.

„A Rajk-per tanulságait belpolitikai viszonylatban még nem vontuk le - mondta Balogh. - Nem történt egyéb, mint hogy néhány kommunistát kiszürtek, vagy leváltottak, holott a tanulság az, hogy nem az a fontos mindenekelött, hogy valaki kommunista legyen, hanem, hogy a magyar-szovjet barátság tekintetében legyen megbízható. Még mindig túlságos nyomás nyilvánul meg annak érdekében, hogy az emberek a kommunista pártba lépjenek. Állást kapni enélkül szinte lehetetlen. Ezért a helyzetért a polgári társadalom, a parasztság közvetve a Szovjetuniót teszi felelőssé és ezért irányában elhidegülés mutatkozik. Ez nem érdeke annak a szellemnek, melyre feltétlenül szükség van a szovjet-magyar barátság kimélyítése érdekében.

Másodszor: a Kominform határozatait ${ }^{464}$, amelyeket Budapesten Kádár János belügyminiszter ismertetett és fordított át a magyar viszonyokra és amelyekre a parlamentben én adtam választ, nálunk semmibe sem veszik, sőt sokszor úgy néz ki, hogy pont ellenkező magatartás nyilvánul meg. Tudom, hogy ez súlyos kijelentés, de állításomat könnyen bizonyíthatom. A Kominform a béke megörzése jegyében különös figyelmet fordít a katolikus hívek vallásos érdekeire és érzékenységére. Politikai felfogásra, pártállásra való tekintet nélkül kíván mindenkit a békefrontba tömöríteni. Ezzel szemben nálunk katolikus intézmények tervszerü szétzüllesztése folyik. A kormány a legkisebb gesztust sem tette az egyház felé, holott azóta a püspöki kar

\footnotetext{
${ }^{463}$ SZCSPL HBI 638.

${ }^{464}$ A Kommunista és Munkáspártok Tájékoztató Irodája (Kominform) 1948. június 28-án hozott határozatában az agrárszektor szövetkezetesítési folyamatának fölgyorsítása mellett (amelynek kapcsán bírálta Titót és a jugoszláv politikát is) a történelmi egyházakkal való mielőbbi megegyezést is sürgette.
} 
minden ellentétel nélkül engedélyt adott a papságnak az alkotmányra való eskü letételére. A politikai pártok tekintetében nem történt több annál, hogy az országgyülés elnöke ${ }^{465}$ Sztálin születésnapja alkalmával mondott beszédében azokról is említést tett. Ennek a magatartásnak a Kominform szándékával szemben természetesen az az az eredménye, hogy a magyar nép nem egységes még a béke és a háború kérdésének megítélésében sem." ${ }^{466}$

Saját érdekeltségeiről - és ezek kapcsán sérelmeiről - is szólt a páter. Így, hogy államosították több lapját: a Magyar Nemzetet, a katolikus olvasóknak szánt Magyar Vasárnap címü hetilapot és szatirikus Szabad Szájat, amelyben Balogh visszaemlékezései szerint Rákosi Mátyást saját kérésére soha nem lehetett karikírozni. ${ }^{467} \mathrm{Az}$ államosítás ténye ellen nem volt kifogása, azt viszont elpanaszolta Farkas Mihálynak, hogy egykori munkatársának - és pártja volt országgyülési képviselöjének - Parragi Györgynek szerkesztőként alig van ráhatása a Magyar Nemzetben megjelenő cikkekre, sőt gyakran az ő írásait is átírva közlik. ${ }^{468}$

Farkas Mihály a Rajk-perrel és az egyházpolitikával kapcsolatos észrevételekre nem reagált, viszont az államosítás lefolyásáról és a közvélemény azzal kapcsolatos hangulatáról érdeklődött. Balogh elmondta, hogy az államosítás módjával elégedetlenek a legtöbben, mivel a tényét már elfogadták.

„Magát az államosítást már várták az érdekeltek - fogalmazott Balogh páter -, így az valami nagy recenzust nem váltott ki, annál inkább a mód, ahogyan sok helyen az államosítást végrehajtották, éjszaka, kíméletlenül, egészen kis embereket is államosítva, ahol a mühely együtt volt a lakással, még a lakásból is kidobták őket. Itt van nálam, éppen most kaptam az egri érsek ${ }^{469}$ levelét és fellebbezését. Az ő téglagyárát államosították és ezzel kapcsolatban még az érseki iroda írógépét is elvitték. Képzelheted, hogy ez az egész városban, sőt az egyházmegyében is milyen felháborodást váltott ki." ${ }^{470}$

\footnotetext{
465 Drahos Lajos 1949. augusztus 23. és 1951. május 18. között volt a Magyar Népköztársaság Országgyülésének elnöke. 1949. december 21-én Sztálin hetvenedik születésnapján mintegy tizenöt perces méltató beszédet mondott róla a magyar országgyülésben.

${ }^{466}$ SZCSPL HBI 674.

${ }^{467}$ BIV

468 SZCSPL HBI 674

${ }^{469}$ Czapik Gyula (1887-1956) 1939 és 1943 között veszprémi püspök, 1943-tól haláláig egri érsek.

${ }^{470}$ SZCSPL HBI 674
} 
Farkas Mihály erre válaszul ezeket elszigetelt jelenségeknek nevezte, hozzátette: „2000 államosítást figyelembe véve, mert most ennyiröl van szó, lehettek olyan végrehajtó szervek is, amelyek túlkapásokkal, ostoba kegyetlenkedéssel jártak el, ezeket azonban minden esetben korrigáljuk. Az érsek úr kérvényét átveszem és természetesen ott is a legnagyobb körültekintéssel fogunk eljárni”- mondta Farkas Mihály. ${ }^{471}$

Balogh István politikai aktivitása és az egyházi vezetőkkel való kapcsolatrendszere az egyházi fenyíték és a sztálini mintájú diktatúra bevezetése ellenére is megmaradt. Nemcsak a budapesti ferencesekkel és Sík Sándor piarista tartományfönökkel tartotta szorosan a kapcsolatot, de Czapik Gyula egri érsekkel is. 1950. március 1-jén például - derül ki Györffy Tibor államvédelmi főhadnagy egy héttel későbbi jelentéséből - Czapik meglátogatta Baloghot a Független Magyar Demokrata Párt székházában, ahol több mint fél órán keresztül egyeztettek. Az volt ugyanis a tervük, hogy a Balogh-pártból egy kifejezetten keresztény elkötelezettségü, de az egyházakhoz hivatalosan nem kötődő szervezetet hozzanak létre. ${ }^{472}$ Betöltendő az egy évvel korábban föloszlott Demokrata Néppárt általa magyar politikai életben hagyott ürt.

Harmat Frigyes államvédelmi hadnagy 1950. június 13-án jelentette, hogy Balogh rendszeresen egyeztet Sík Sándor piarista és Csávossy Elemér jezsuita tartományfönökkel, valamint Endrédy Vendel ciszterci zirci apáttal, s az állam és a katolikus egyház közötti megállapodás szükségességét és sürgősségét bizonygatja nekik. ${ }^{473}$ Ugyancsak ebben a jelentésben olvashatjuk, hogy „Pressl József volt munkáslelkész f. hó 5-én elmondta, hogy Balogh Istvánnal való tárgyalásakor Balogh kijelentette, hogy amennyiben lengyel mintára lehetséges volna a megegyezés, akkor meg kell tenni mindent. De itt a baj a kommunisták részéről, hogy már az első hallgatólagos megállapodást sem tartották be. Balogh célzott arra, hogy ígéretet kapott, hogy az esetleges megállapodás létrejöttéig a sajtó az alsópapságot nem támadja, és ennek ellenére nap mint nap támadást intéznek az alsópapság egyes tagjai ellen is.

\footnotetext{
${ }^{471}$ SZCSPL HBI 674.

472 ÁBTL 3.1.5. O - 10973. 119.

473 Az állam és egyház közötti 1950. augusztus 30-i megállapodást megelőző tárgyalásokról: Gergely Jenő: Az 1950-es egyezmény és a szerzetesrendek feloszlatása Magyarországon. Dokumentumok. Budapest, 1990. 23-329.
} 
Beszélgetés közben kijelentette: ezt az állam tudatosan teszi, mert nem akar megegyezni." 474

Pressl „,volt munkáslelkész” 1946 októberében még mint Páter Pressl Bernardin $\mathrm{O}[\mathrm{rdo}] \mathrm{M}[$ ariavitae], a Fehérváry Tamás - eredeti nevén Csernohorszky Gyula - püspök vezette Máriavita Ókatolikus Magyar Nemzeti Egyház ${ }^{475}$ püspöki irodaigazgatója írt levelet „elvtársi üdvözlettel” Justus Pálnak, a Szociáldemokrata Párt agitációs és propaganda osztálya vezetőjének. Ebben felekezetük lapja, a Nemzeti Egyház havonta egyszeri megjelentetéséhez kéri a párt anyagi támogatását.

A kérelmet végül elutasították a szociáldemokraták, de a levél érdekes utat járt be a pártközpontban. Horváth Zoltán a párt főtitkárságának irodavezetője 1946. október 29-i glosszájában költséges és kevés politikai haszonnal járó vállalkozásnak tartaná a lap támogatását, s „,ha már ilyesmit csinálunk - írta -, jobb lenne a szabad egyházakkal kezdeni (Michnay), mert azoknak vannak tömegeik”. Justus november 7-én írta rá, hogy egyetért Horváthtal. Bán Antal iparügyi miniszter négy nappal később lejegyzett véleménye szerint a máriaviták segítése „egyszerüen azt jelentené, hogy a kat[olikus]. egyház ellen megkezdtük a gyakorlati kultúrharcot”. Schiffer Pál, a párt főtitkárságának munkatársa úgy vélte, a levelet meg sem kell válaszolni. ${ }^{476}$

A máriavita ókatolikus mozgalomnak ugyan túl sok híve nem volt az 1940-es évek második felében Magyarországon, politikai támogatása viszont igen. A kommunisták öket akarták fölhasználni a katolikus egyház ellen, hiszen öltözetük, liturgiájuk, hittanításaik jelentős része jobbára megegyezett a katolikusokéval. Sőt, egy független nemzeti katolikus egyház alapjaiként is tekinthettek rájuk. ${ }^{477}$

Érdekes, hogy ugyanebben az időben Balogh pátert is kapacitálták egy Rómától független magyar katolikus egyház megszervezésére. ${ }^{478}$ (Ilyen jellegű próbálkozásuk

\footnotetext{
474 ÁBTL 3.1.5. O - 10973. 126.

475 Vö. Miklós Péter: Máriavita ókatolikus püspöki pásztorlevél 1945-ből. Magyar Egyháztörténeti Vázlatok, 22 (2010). 1-2. sz. 159-168.

${ }^{476}$ PIL 283. f. 10/213. ö. e.

477 Lásd bővebben: Balogh Margit: Elvetélt fordulatok az egyházpolitikában. Kísérletek a nemzeti katolikus egyház megteremtésére Magyarországon. In: Évkönyv. 1992. Szerk. Bak János. Budapest, 1992. 227-241.

478 Barlay Ö. Szabolcs (*Kassa, 1919. október 31.) katolikus pap, egykori ciszterci szerzetes szóbeli közlése. 2009. szeptember 24.
} 
volt a csehszlovák kommunistáknak a kérészéletű Csehszlovák Katolikus Akció létrehozása. ${ }^{479}$ )

Balogh páter azonban mindezt a nyilvánosság előtt nemcsak cáfolta, de kifejezetten és határozottan tagadta. 1949. március 15-én a Magyar Függetlenségi Népfront alakuló nagygyülésén a budapesti Sportcsarnokban így beszélt erről:

„A rémhírterjesztők forrásai, úgy látszik, kiapadtak, mert ezen a téren kevesebb bosszantás éri az embereket. Most a reakció új fegyvert használ és rágalom hadjáratot indít a demokrácia ellen. Gonosz híresztelés járja be a békés dolgozók hajlékát, nem kerülve ki a vidéki plébániák küszöbét sem. Azt mondják, hogy a demokrácia új nemzeti egyház alapítását tervezi. E rágalom gonoszságánál csak ostobasága nagyobb. Mégis ez ünnepélyes alkalommal is vissza kell utasítani, mert nemcsak egyszerü hívek, hanem papok, sőt föpapok is hitelt adnak e propagandának. Sem a kormány, sem annak egyetlen szerve nem foglalkozott ilyen gondolattal. Magam nem lehetnék tagja a Népfrontnak, ha erről meggyőződést nem szereztünk volna.

Ellenkezőleg, örömmel látjuk a Magyar Függetlenségi Népfront programnyilatkozatának 8. pontjában foglalt »nyitott kapu« gondolatát, mely nyitva hagyja az egyház és állam megegyezése előtt az ajtót. Mi, a Magyar Függetlenségi Népfront keretén belül is teljes egyetértésben és harmóniában az elnökség szándékaival, különösen arra akarunk vigyázni továbbra is, hogy a belföldi reakció, valamint az imperialisták macchiavellista propagandája ezt a kaput ne csaphassa be. A magyar népet e tekintetben nem fogja megtéveszteni semmiféle »Amerika hangja«. Az elmúlt hetek vásári lármájából, mely New Yorktól Madridon át Ankaráig meg nem állt, ma már mindenki látja, hogy annak egyetlen célja a háborús uszítás volt. A kultúrvilág nem türheti, hogy a magyar nép legszentebb vallásos érzelmeivel ilyen lelkiismeretlenül visszaéljenek." 480

1950. augusztus 1-jén került sor a magyar katolikus papok első országos békeértekezletére, amelyen Balogh páter, Horváth Richárd és Darvas József vallás- és közoktatásügyi miniszter szólalt föl. ${ }^{481}$ Balogh Az eddigi egyházi politikával szakítani kell címmel tartott előadást, amelyben meg nem nevezve ugyan, de bírálta Mindszenty

\footnotetext{
${ }^{479}$ Vö. Hal'ko, Jozef: A csehszlovák szakadár Katolikus Akció. Kommunista kísérlet a katolikus egyház nemzeti egyházzá formálására Csehszlovákiában. Esztergom-Piliscsaba, 2004.

${ }^{480}$ Magyar Nemzet, 1949. március 17.

${ }^{481}$ A békegyülésen elhangzott beszédek értékelése: Gergely Jenő, 1989. 134-137.
} 
József tevékenységét, valamint üdvözölte az állam és a katolikus egyház közötti tárgyalásokat

„Az eddigi hivatalos egyházi politika életveszélyesnek bizonyult - fogalmazott Balogh, majd így folytatta: - Ezzel szakítani kell.

Ez az, amit a püspöki kar kétségtelenül belátott, amikor most végre odaült a tárgyalóasztalhoz. Belátta ezt a magyar katolikus papság is, amikor a tárgyalások sikere érdekében a mozgalmat megindította.

Nem lehet, hogy mi katolikus papok tétlenül nézzük ezt és legfeljebb kezünket tördeljük a pusztulás láttán. Hamis és túlságosan olcsó álláspont lenne. Hamis, mert a felelősséget, amennyire az minket terhel, magunknak kell viselnünk, és nem háríthatjuk át semmiféle hatóságra vagy személyre." 482

Balogh István a papi békemozgalmat a mielőbbi megállapodás letéteményeseként nevezte meg, s a megjelenteket a béke, a népi demokrácia, az ötéves terv és a Magyar Függetlenségi Népfront nyílt és határozott támogatására buzdította. ${ }^{483}$

A magyar katolikus püspöki kar 1950. november 7-i ülésén tárgyalta az állam azon ajánlatát, hogy a felfüggesztett, illetve egyházi fenyítékkel sújtott békepapok helyzetének kánoni rendezéséért cserében internált, illetve őrizetben lévő papokat bocsátanak szabadon.

A föpapok az ajánlatot elfogadták, Balogh páter esetében azonban nem érezték illetékesnek magukat, hiszen ö - vélték a püspökök - az elnöki tanácsi tagság elfogadásával kvázi miniszteri rangú tisztséget vállalt, ehhez viszont az Apostoli Szentszék engedélye kellett volna, amit Balogh - szabálytalanul - nem kért. Így ügye a magyar püspökök szerint a Vatikán illetékességi körébe tartozott. ${ }^{484}$

Balogh István politikai karrierje 1951 nyarán ért véget.

1951. június 5-én rövid vizsgálati fogságba került, ám néhány óra múlva szabadult. Három nappal később országgyülési képviselői mandátumáról, 1951.

\footnotetext{
${ }^{482}$ Balogh István: Az eddigi egyházi politikával szakítani kell. In: Katolikus papok a békéért. A katolikus papok 1950. augusztus 1-i országos értekezletén elhangzott beszédek és elfogadott határozatok. Budapest, 1950. 20.

${ }^{483}$ A papi békemozgalom létrejöttének politikai következményeiröl: Gergely Jenő: A katolikus egyház Magyarországon. 1944-1971. Budapest, 1985. 123-146. és Pál József: Békepapok. Katolikus békepapok Magyarországon. 1950-1989. Budapest, 1995. 9-112.

484 A Magyar Katolikus Püspöki Kar tanácskozásai 1949-1965 között. Borovi József gyűjtésének felhasználásával összeáll. Balogh Margit. (a továbbiakban: MKPKT, 2008) 1. köt. Budapest-Szeged, 2008. 300-301.
} 
december 14-én a Népköztársaság Elnöki Tanácsban betöltött tagságáról mondott le. Időközben a lakásán fölhalmozott mükincsgyüjteménye - benne festmények, szobrok, szőnyegek, bútorok, csillárok - nagy részét lefoglalták és beszállították a Szépmüvészeti Múzeumba.

Balogh ekkor ismét fölvette a kapcsolatot Hamvas Endre csanádi püspökkel, s az engedélyét és támogatását kérte a csanádi egyházmegyébe való visszatéréshez. A püspök - miután Balogh kijelentette: szakít a politika világával - a szőregi, illetve az apátfalvi plébániára való kinevezést vetette föl. ${ }^{485} \mathrm{Az}$ ügy még a püspöki kar 1951. június 15-i értekezletén is előkerült, ahol Hamvas megerősítette a föpapoknak, hogy „Balogh teljesítette a feltételeket: lemondott tanácselnökségi tagságáról képviselőségről - békepapok mozgalmáról. ${ }^{486}$ Plébániát kér."487

Egy 1951. június 7-én kelt államvédelmi jelentés szerint - nem túlságosan hízelgő módon - „Balogh Istvánról a papi Békebizottságban úgy vélekedtek, hogy előállításának oka nyilván gazdasági természetü. Olyan vélemények is voltak, hogy lelepleződött kétkulacsos politikája és ő volt az, aki a Papi Békebizottságról adatokat szolgáltatott a püspököknek. Neki tulajdonították, hogy több bizalmas adat került ki a bizottság munkájából és többen bizalmatlanok személyével kapcsolatban." ${ }^{488}$

S hogy Balogh páter politikai pályafutásának 1951 júniusára elérkezett a vége, azt az imént idézett dokumentum is megerősíti, amely szerint „Balogh István személyével sem az egyház, sem a polgári politikusok körében említésre méltóan nem foglalkoznak". 489

Ennek ellenére az Államvédelmi Hatóság felügyelet alatt tartotta, s elhatározta a fővárosból való eltávolítását. Előbb a Budapesttől negyven kilométerre fekvő Pest megyei Bold községbe akarták internálni, végül Kemencét jelölték ki számára tartózkodási helyül. Hivatalosan lelkipásztori szolgálatot látott el a faluban. ${ }^{490}$

\footnotetext{
${ }^{485}$ Haas György, 2010. 172.

${ }^{486}$ Balogh István országgyülési mandátumáról 1951. június 8-án mondott le, az elnöki tanácsnak azonban még 1951. december 14-ig tagja volt.

${ }^{487}$ MKPKT, 2008. 1. köt. 352-353.

488 ÁBTL 3.1.5. O - 10973. 72.

489 ÁBTL 3.1.5. O - 10973. 72.

490 Vö. Izsák Lajos hozzászólása Gergely Jenő előadásához. In: Gergely Jenő: A katolikus egyház Magyarországon 1944 után. Budapest, 1991. 29-30.
} 
Budapestre csak három évvel később, Nagy Imre első miniszterelnöksége és az „új szakasz” politikájának meghirdetése után térhetett vissza. 


\section{EPILÓGUS}

Balogh István 1954 nyarán térhetett vissza Kemencéről Budapestre. A fővárosban a lakásán Nagy Imre miniszterelnök személyesen kereste föl, s elvitte neki Egy évtized. Válogatott beszédek és írások (1954) címü kétkötetes munkájának dedikált példányait. ${ }^{491}$ Balogh páter hivatalosan 1954 és 1957 között a budapesti Thököly úti, egykori domonkos rendi Rózsafüzér Királynéja templom templomigazgatója volt.

Korábbi kisgazda képviselőtársa, Ortutay Gyula 1954. augusztus 31-i naplóbejegyzésében írta, hogy „Balogh páter feltünt Pesten: itt lesz plébános, s Oltványi ${ }^{492}$ véletlenül találkozott is vele a Pilvaxban: a vén szélhámos ismét jókedvű és sejtelmesen kacsintgat. ${ }^{493}$ Ugyanő két hónappal később, a Hazafias Népfront kétnapos kongresszusa után, 1954. október 26-án a következőket jegyezte föl: „Ott ült a párt két szárnya, s a pártonkívüli pártok képviselői, még Balogh páter terjedelmes mosolya is kivirított, Dinnyés is oda-odadöcögött a büféasztalhoz egy feketét meginni, egy virsliért." 494

Balogh az 1956-os forradalomban és szabadságharcban nem vett részt, viszont annak bukása után fölajánlotta szolgálatait az új politikai vezetésnek, ám a Kádár János vezette kormány visszautasította. Formális szerepet vitt a papi békemozgalomban, tényleges politikai tevékenységet azonban nem folytatott.

1957-es nyugdíjba vonulása után 1962-től halálig a pesti Váci utcai Szent Mihály templom (volt angolkisasszonyok temploma) templomigazgatója volt. Ezekben

\footnotetext{
${ }^{491}$ BIV

492 Oltványi Imre (1893-1963) művészettörténész, kisgazda politikus, 1945 júniusa és decembere között pénzügyminiszter, utána 1946 júliusáig a Pénzintézeti Központ elnöke, később berni nagykövet, majd a Szépmüvészeti Múzeum főigazgatója.

493 Ortutay Gyula: Napló. 1. köt. 1938-1954. Szerk. Markó László. Budapest, 2009. 533.

${ }^{494}$ Uo. 541.
} 
az években Paskai László - akkor fiatalabb paptársa - megkérdezte tőle, hogy miért nem írja meg az emlékiratait. „Mert élni akarok” - hangzott a válasz. ${ }^{495}$

Balogh Istvánnak Hamvas Endre csanádi püspök 1962-ben a Szent Miklósról nevezett pordánymonostori címzetes apáti méltóságot adományozta. A magyar egyházi szokásjog alapján a címzetes apát akkoriban még olyan föpapi jelvényekkel - például infula, pásztorbot, mellkereszt, kesztyü - mutathatott be szentmisét, mint a püspök. Ezeken túl a liturgián kívül is viselhetett gyürüt és drágakő nélküli mellkeresztet, valamint lila cingulust a rubinszínü gombokkal díszített fekete reverendához. Balogh páter a kortárs egyháziak szerint nagy örömmel mondott misét az elöbb említett főpapi öltözetben és jelvényekkel, hangsúlyozva apáti méltóságát. ${ }^{496}$

1971 nyarán készítette el végrendeletét. Ebben tekintetét „,az Örökkévalóság felé irányítva" fogalmazta meg akaratát. Örökösei Bajdik Andrásné Papp Magdolna (aki édesanyját ápolta), Vadovits Teréz (aki a házvezetésben segítette) és unokahúga, Berkes Illésné Balogh Viola voltak. A számára a betegek kenete szentségét kiszolgáltató papnak egy Szent Ferenc-ereklyét, az őt eltemető lelkésznek pedig egy antik Szüz Mária-képet szánt. A ferencesekre hagyott egy takarékbetétkönyvet, amely ezer csendes szentmise stóladíját fedezte, $\mathrm{s}$ amelyek bemutatását a halálát követően a lehető leghamarabb kívánta. Az egyházi temetés legegyszerübb formáját kérte. ${ }^{497}$

Balogh István 1976. július 20-án hunyt el Budapesten (a halotti anyakönyvi bejegyzés szerint szívizomelhalásban). ${ }^{498}$ A farkasréti temető 19/1. parcellájában (1. sor 119.) helyezték örök nyugalomra.

\footnotetext{
495 Paskai László (*Szeged, 1927. május 8.) bíboros, kiérdemesült prímás, esztergomi érsek szóbeli közlése. 2011. április 12.

496 Barlay Ö. Szabolcs (*Kassa, 1919. október 31.) katolikus pap, egykori ciszterci szerzetes szóbeli közlése. 2009. szeptember 24.

${ }^{497}$ A végrendelet szövegét közli: Haas György, 2010. 181-183.

${ }^{498}$ BFL XXXIII. 1. a. 42. köt. Budapest, II. ker. 1976. Halotti anyakönyv [856-1700]. 1006.
} 


\section{VII. ÖSSZEGZÉS}

Dolgozatomban különböző forrástípusok - központi kormányzati iratok, egyházi levéltári dokumentumok, visszaemlékezések, korabeli sajtótermékek - alapján igyekeztem bemutatni Balogh István politikai pályáját. Miközben természetesen az életrajzi kereteket és adatokat is ismertettem, munkám fókuszában 1944 decembere és 1951 decembere közötti politikai tevékenysége és 1944 vége és 1947 májusa közötti kormányzati szerepvállalása, illetve ezek előzményeként szegedi évei álltak.

Szegedi lelkészi és várospolitikai munkásságának ismertetése mutatja, hogy Balogh páter már a Horthy-korszakban aktív közéleti szereplő volt, akinek politikai ambíciói igen hamar megmutatkoztak. Ennek megfelelöen minden eszközzel be szeretett volna kerülni a városi törvényhatósági bizottságba, illetve különböző helyi terjesztésü lapok - Szegedi Hirlap és Tanyai Újság - kiadásával saját tevékenységét és politikai nézeteit osztotta meg a közvéleménnyel. Ezzel nemcsak a társadalmi nyilvánosság számára akart információkat biztosítani, de meghatározó és véleményformáló várospolitikai tényezővé is szeretett volna válni. Ezen törekvésében pedig nem válogatott a szövetségesekben: segítségét és lapját az 1930-as évek közepén éppúgy fölajánlotta a kormánypártnak, mint az ellenzéki Független Kisgazdapártnak.

Szegeden - még belvárosi segédlelkészként - kapcsolatba került a két világháború közötti politikai rendszer hivatalos ideológiája, a keresztény nemzeti gondolat megalapozóival: Bangha Béla jezsuita páterrel és az akadémikus Szekfü Gyula történészprofesszorral. 1929-ben doktori címet szerzett a szegedi egyetem, amely egyaránt mutatja a doktorátussal járó társadalmi presztízs iránti igényét, illetve tudományos ambícióit. Aligha véletlen, hogy doktori értekezésének szövegezésekor írt levelet Szekfünek, amelyben az őt Szegeden ért támadásokról tájékoztatta.

Balogh István disszertációjában tizenhatodik század eleji velencei követjelentéseket adott közre magyarul, amelyeket jegyzetekkel és bevezető tanulmánnyal látott el. A Velenczei diplomaták Magyarországról. 1500-1526 címü munka időtállónak bizonyult, hiszen a korszakkal foglalkozó kutatók napjainkban is elismeréssel hivatkoznak rá. 
Balogh páter az 1930-as-1940-es években Szeged-Alsóközpont - a mai Mórahalom város - plébánosa volt. A Duna-Tisza-közi Homokhátság tanyavilága lelkészeként egészen más kihívásokkal találkozott, mint a szegedi belvárosban. A levéltárakban fönnmaradt iratok tanúsága szerint itt is - mint később szintén, életútja bármely állomásán - legjobb tudása és lehetőségeinek maximális kihasználásával dolgozott. Ebben a közösség szolgálatának eszménye mellett személyes érdekei is szerepet játszottak. Lelkipásztori problémákat - a fiatal jezsuita atyák lelkipásztori ellátásba való bevonásától a tanyavilágban fölbukkanó kisegyházak kérdéséig akkoriban éppúgy igyekezett megoldani, mint szerepet vállalni a parlamenti választások helyi kampányában, de a szociális igazságtalanságok fölszámolására a polgármesterrel vagy a föispánnal is hajlandó volt vitába szállni a nyilvánosság előtt.

1944 novemberében szinte véletlenül vált az országos politika szereplőjévé. Amikor Szegeden - mint a szovjet megszállás alá került első magyar nagyvárosban megindult a politikai élet újjászervezése, ő képviselte a Független Kisgazdapártot a pártközi tárgyalásokon, s egykori lapját, a Délmagyarországot is a formálódó kormánykoalíció szolgálatába állította. Jó időben volt tehát jó helyen, s 1944 decembere és 1945 áprilisa között nemcsak a kisgazdapárt helyi szervezetének, de a Szegedi Nemzeti Bizottságnak és a Magyar Nemzeti Függetlenségi Frontnak is elnöke volt.

1944 decemberében elöbb az Ideiglenes Nemzetgyülés képviselőjévé választották, majd az Ideiglenes Nemzet Kormány miniszterelnöke, dálnoki Miklós Béla mellett vezette a miniszterelnöki hivatalt. Ezt a posztot később Tildy Zoltán és Nagy Ferenc kabinetjében is betöltötte. A kortársak szerint a kormányban - a talán Nagy Ferenc kivételével nem túl erőskezű miniszterelnökök mellett - jelentős befolyásra tett szert, s az államigazgatásban is pozícionálta saját híveit (például Bojta Bélát, a Népbíróságok Országos Tanácsának elnökét, vagy Pálffy György szegedi föispánt).

Balogh István államtitkárként számos fontos területért felelt. Hozzá tartoztak 1944 végétől 1945 áprilisáig a sajtóügyek és a papírellátás kérdései, amelyek révén a pártvezetők gyakran fordultak hozzá lapengedélyekért, illetve a pártorgánumok számára megfelelő mennyiségü nyomdai papírért. Persze ekkoriban nem feledkezett meg saját újságjainak - Magyar Nemzet, Mai Nap - papírellátásról sem. Ezek a lapok - az 1950es államosításig -végig rendelkezésére álltak. Egyetlen volt a koalíciós évek politikusai közül, akinek nem pártérdekeket, hanem saját érdekeit szolgáló hírlapjai voltak. 
A koalíciós évek legelején érdekeltségi körébe tartozott még a szegedi megjelenésű Délmagyarország is, amelynek 1944 novembere és 1945 áprilisa között szerkesztőbizottsági tagja is volt, s amelynek hasábjain - államtitkári kinevezése előtt több politikai tárgyú írása (például a Magyar Nemzeti Függetlenségi Front alapelveiről vagy a békekötés föltételeiről és körülményeiről) is megjelent.

Balogh páter 1944 végétöl 1949 májusáig tagja volt a törvényhozás politikai bizottságának. 1945-ben ő terjesztette elő a testületnek - mint annak titkára - a fölbirtokreform végrehajtásával kapcsolatos azon igényeket, amelyekben a földtulajdonosok politikai (például németellenes és antifasiszta tevékenység) érdemeikre hivatkozva kérték birtokuk megtartását, illetve azok mentesítését a fölbirtokreform végrehajtása során való fölhasználás alól. Ebben a minőségében volt szerepe a veszprémi és a székesfehérvári püspöki uradalom mentesítésének engedélyezésében is.

A miniszterelnöki hivatalt vezető államtitkárként természetesen közbenjárt a katolikus egyház érdekében is a kormánytagoknál: internált, vagy népbírósági eljárásban meghurcolt egyházi személyek ügyét éppúgy képviselte, mint ahogy politikai tanácsokkal segítette a főpapokat. 1944 végétől kezdve igyekezett közvetíteni az újonnan szerveződő állam és a katolikus egyház között. Emiatt voltak konfliktusai is egyházi elöljáróival, hiszen a katolikus felsőklérus nem nézte jó szemmel, hogy sürgeti előbb a köztársasági államforma egyházi részről való üdvözlését, később az állam és egyház közötti mielőbbi megegyezést. 1948 nyarára a Balogh páter és a katolikus egyház vezetése közötti konfliktus odáig fajult, hogy püspöke fölfüggesztette papi szolgálatának gyakorlásában.

Balogh István 1947 májusában távozott a miniszterelnökségi államtitkári székből. Három hónappal később pedig szakított a Független Kisgazdapárttal is amelynek 1947 elejétől országos fötitkára volt - és új önálló politikai formációt hozott létre, a Független Magyar Demokrata Pártot, amelyet a korabeli köznyelv egyszerüen Balogh Pártnak hívott (ez még a szervezet hivatalos fejléces papírjain is megjelent).

A párt heterogén politikai csoport volt, hiszen frakciójában helyet kapott a szegedi ellenforradalmi kormány volt miniszterelnöke P. Ábrahám Dezső éppúgy, mint a Nemzeti Parasztpárt egykori főtitkára, Kovács Imre (aki a képviselőcsoporton belül a néhány hívéből álló független parasztpártiak csoportját vezette). Az 1947. augusztusi országgyülési választásokon alig több mint ötszázalékos eredményt elérő, s így a törvényhozásba tizennyolc képviselőt juttató Független Magyar Demokrata Párt 
frakcióját azonban elsősorban Balogh régi politikai szövetségesei - például Parragi György, Kunszery Gyula, Hegedüs Gyula - alkották.

Balogh pártja keresztény alapokon álló polgári pártként - az 1945-ös Független Kisgazdapárt által képviselt értékek letéteményesként - határozta meg magát. Programjában demokratikus elveket vallott, s sürgette az Apostoli Szentszékkel való diplomáciai kapcsolatok rendezését. Ezek a hangzatos jelszavak ugyan a polgári ellenzéki pártok sorába utalták a Független Magyar Demokrata Pártot, amely azonban 1947 őszétől már - nyíltan vállaltan - „mérsékelt ellenzéki”, illetve „lojális ellenszéki” szerepet játszott. Így Balogh Istvánt és képviselőtársait hamar a kormány támogatói közé sorolta a közvélemény, noha maga Rákosi Mátyás volt az, aki többször hangoztatta, hogy Baloghnak és pártjának nincs helye a koalícióban.

Balogh és szervezte 1949-ban csatlakozott a Magyar Függetlenségi Népfronthoz. A páter ismét országgyülési mandátumhoz jutott, de tagja lett a kollektív államföi testületnek, a Népköztársaság Elnöki Tanácsának is. 1950-ben szerepet vállalt a békepapi mozgalom megszervezésében. Politikai pályája 1951 júniusában ért véget, amikor rövid vizsgálati fogság után kitelepítették Budapestről és Kemencére költöztették, ahol formailag helyettes plébánosként szolgált. 1951 júniusában parlamenti képviselői megbízásáról, 1951 decemberében elnöki tanácsi tagságáról mondott le.

Balogh páter alakja a köztudatban a kommunista állammal elvtelenül együttmüködő lelkész jelképévé vált, míg mások - s ő maga is így vélekedett saját magáról - úgy gondolják, politikai pályáján a (kiépülő) kommunista rendszer és a katolikus egyház elvei és elvárásai között próbált egyensúlyozni - több-kevesebb sikerrel.

Tevékenyégét egykori politikustársai is eltérően ítélik meg.

Horváth János - aki 1945 novemberétől 1947. januári letartóztatásáig kisgazda nemzetgyülési képviselő volt - szerint Balogh nem szerette sem a szovjet megszállókat, sem az egypártrendszer kiépítésére törekvő kommunistákat, de az elsők között látta be, hogy a magyar politikusoknak - ha pozíciójukat meg akarják tartani - nincs más választása, mint a velük való együttmüködés.

Úgy vélte ugyanis - emlékszik vissza Horváth János -, hogy politikai posztokról jobban lehet képviselni a keresztény egyházak érdekeit és a polgári politika értékeit. 
Horváth szerint Balogh keresztény és nemzeti elkötelezettségü volt, ám reálpolitikusként alkalmazkodott a körülötte kialakuló helyzethez. ${ }^{499}$

Merőben másként látta Kovács K. Zoltán - 1947 szeptemberétől 1949. februári emigrálásig a Demokrata Néppárt országgyülési képviselője -, aki fiatal parlamenti képviselőként kifejezetten tartott Balogh pátertől. Az ellenzéki pártok képviselői ugyanis úgy tartották, hogy aki vele barátkozik, vagy szövetkezik, az könnyen bajba kerülhet, s úgy tudták, igazából nem élvezi sem a baloldali, sem az ellenzéki pártok bizalmát, pártját pedig csak az érdekszövetség tartja össze.

Kovács K. Zoltán opportunista, a hatalomért mindenre képes politikusként emlékezett Baloghra, akit ezen tulajdonsága alapján Ortutay Gyulához, illetve Dobi Istvánhoz hasonlított. ${ }^{500}$

Balogh páter érdekes és megkerülhetetlen alakja huszadik századi történelmünknek. Értekezésemben egyházi és politikai pályájának - életének az 1920-as évek végétől 1951-ig tartó periódusa - áttekintésével igyekeztem a róla alkotott - mint láttuk, meglehetősen sematikus - képet árnyalni.

Tény, hogy okos, ravasz és jó helyzetértékelő képességgel megáldott politikus volt, aki a Horthy-korszak kormánypártjával, a koalíciós évek eltérő ideológiai alapállású politikai erőivel és az államszocializmus rendszerének alakítóival is jó kapcsolatot tudott kialakítani. A magyar katolikus egyház vezetése ugyanakkor nem nézte jó szemmel papja állandó simulását az éppen aktuális hatalmi tényezőkhöz, s ezért alapvetően nem támogatta politikai tevékenyégét.

Balogh köré már életében legendárium szövődött. Sokan tudtak pártalanul gazdag gyüjteményéről, amelyben értékes bútorok, szőnyegek, órák mellett szobrok és festmények is helyet kaptak: többek között olyan magyar klasszikusok, mint Mednyánszky László, idősebb Markó Károly, Benczúr Gyula és Rippl-Rónai József alkotásai. Emellett a budapesti művészvilágban is ismert volt. Házába bejáratos volt Csók István, Szőnyi István, Kisfaludi Stróbl Zsigmond, Márai Sándor, Tamási Áron és Zilahy Lajos is. ${ }^{501}$

\footnotetext{
${ }^{499}$ Horváth János (*Cece, 1921. november 7.) szóbeli közlése. 2007. augusztus 28.

${ }^{500}$ Kovács K. Zoltán (Magyaróvár, 1924. március 27. - 2008. március 6.) szóbeli közlése. 2007. április 21.

${ }^{501}$ Korányi András, 1995. 325-327.
} 
Doktori értekezésemben Balogh István életrajzához és politikai pályaívéhez közöltem adatokat, amelyek alapján talán könnyebben megérthetjük és értékelhetjük Balogh páter - meglehetősen ellentmondásos - politikai szerepvállalását. 


\section{FELHASZNÁLT FORRÁSOK, IRODALOM}

\section{Források}

Magyar Országos Levéltár

XVIII-5 Ideiglenes Nemzetgyülés Politikai Bizottságának iratai

XIX-A-1-j Miniszterelnökség iratai. Általános iratok (1944-1945)

Állambiztonsági Szolgálatok Történeti Levéltára

3.1.5. O-10973 Dr. Balogh István objektum dossziéja

3.1.9. V-700/44 A Mindszenty-ügy vizsgálati dossziéja

Politikatörténeti és Szakszervezeti Levéltár

274. fond A Magyar Kommunista Párt iratai (1944-1948)

283. fond A Szociáldemokrata Párt iratai (1944-1948)

Országos Széchényi Könyvtár Kézirattára

Fond 7 Magyar Szemle Társaság iratai

Fond 191 Korcsmáros Nándor iratai

Csongrád Megyei Levéltár

IV. B. 1402. a. Szeged város törvényhatósági bizottságának jegyzőkönyvei

VIII. 2. Ferenc József Tudományegyetem Bölcsészettudományi Kar iratai

X. 58. Dugonics Társaság iratai

Bács-Kiskun Megyei Önkormányzat Levéltára

XI. 7. Az Első Kecskeméti Hírlapkiadó és Nyomda Rt. iratai

1. doboz 11. tétel (levelezés, 1930-1948)

XVII. 46. A Kecskeméti Nemzeti Bizottság iratai 
Budapest Főváros Levéltára

XXXIII. 1. a. Állami anyakönyvi másodpéldányok levéltári gyüjteménye.

42. köt. Budapest, II. ker. 1976. Halotti anyakönyvek [856-1700].

Szeged-Csanádi Püspöki Levéltár

I. 1. a. Püspöki hivatal iratai. Egyházigazgatási iratok

IV. 8. Hagyatékok. Balogh István iratai

Magyar Egyháztörténeti Enciklopédia Munkaközösség

Balogh István visszaemlékezése

[Borovi József hagyatékából]

\section{Sajtó}

A Holnap

Délmagyarország

Ellenzék

Hazánk

Kis Újság

Magyar Nemzet

Népszava

Szabad Nép

Szegedi Napló

Szegedi Kis Újság

Vásárhely Népe

Világosság 


\section{Parlamenti naplók}

Az 1944. december 21-re Debrecenbe összegyült, majd később Budapestre összehívott Ideiglenes Nemzetgyülés naplója, 1944-1945. Budapest, 1946.

Az 1945. évi november 29-re összehívott Nemzetgyülés naplója. 1945-1947. 1-8. köt. Budapest, 1946-1952.

Az 1947. évi szeptember 16-re összehívott Országgyülés naplója. 1947-1949. 1-5. köt. Budapest, 1948-1949.

Az 1949. évi június hó 8-ra összehívott Országgyülés naplója. 1949-1953. 1-2. köt. Budapest, 1950-1959.

\section{Publikált források}

A Magyar Katolikus Püspöki Kar tanácskozásai 1949-1965 között. Borovi József gyüjtésének felhasználásával összeáll. Balogh Margit. 1-2. köt. BudapestSzeged, 2008.

A Magyar Kommunista Párt és a Szociáldemokrata Párt határozatai. 1944-1948. Szerk. Rákosi Sándor, Szabó Bálint. Budapest, 1979.

A magyarországi Szövetséges Ellenőrző Bizottság jegyzőkönyvei. 1945-1947. Szerk. Feitl István. Budapest, 2003.

Dálnoki Miklós Béla kormányának (Ideiglenes Nemzeti Kormány) minisztertanácsi jegyzőkönyvei. 1944. december 23. - 1945. november 15. A-B. köt. Szerk., bev., jegyz.: Szűcs László. Budapest, 1997.

Nagy Ferenc első kormányának minisztertanácsi jegyzőkönyvei. 1946. február 5. 1946. november 15. A-B. köt. Szerk., bev., jegyz.: Szűcs László. Budapest, 2005.

Nagy Ferenc második és harmadik kormányának minisztertanácsi jegyzőkönyvei. 1946. november 22. - 1947. május 31. A-B. köt. Szerk., bev., jegyz.: Szűcs László, G. Vass István. Budapest, 2008.

Pártközi értekezletek. Politikai érdekegyeztetés, politikai konfrontáció. 1944-1948. S. a. r., jegyz.: Horváth Julianna, Szabó Éva, Szűcs László, Zalai Katalin. Budapest, 2003. 
Schematismus venerabilis cleri dioecesis Csanádiensis pro anno Domini [1898 - 1947]

Tildy Zoltán kormányának minisztertanácsi jegyzőkönyvei. 1945. november 15. - 1946. február 4. Szerk., bev., jegyz.: G. Vass István. Budapest, 2005.

\section{Balogh István munkái}

Balogh István: Velenczei diplomaták Magyarországról. 1500-1526. Forrástanulmány. Szeged, 1929.

Balogh István: Reálpolitika az egyház és az állam viszonyában. Balogh István öt cikke. Budapest, 1948.

Balogh István: Az eddigi egyházi politikával szakítani kell. In: Katolikus papok a békéért. A katolikus papok 1950. augusztus 1-i országos értekezletén elhangzott beszédek és elfogadott határozatok. Budapest, 1950. 16-23.

Balogh István [visszaemlékezése]. Társadalmi Szemle, 30 (1970). 3. sz. 43-45.

\section{Emlékiratok, naplók}

Berey Géza: Hitler-allee. Budapest, 1979.

Kállai Gyula: A magyar függetlenségi mozgalom története. 1936-1945. Budapest, 1978.

Klebelsberg Kunoné: Életutunk. S. a. r.: Máriaföldy Márton. Szeged, 1992.

Korányi András: Emléktöredékek. Budapest, 1995.

Kovács Imre: Magyarország megszállása. Budapest, 1990.

Mindszenty József: Emlékirataim. Vaduz, 1988.

Nagy Ferenc: Küzdelem a vasfüggöny mögött. 1-2. köt. Budapest, 1990.

Ortutay Gyula: Napló. 1. köt. 1938-1954. Szerk. Markó László. Budapest, 2009.

Rákosi Mátyás: Visszaemlékezések. 1940-1956. 1. köt. S. a. r., jegyz.: Baráth Magdolna, Feitl István, Gyarmati György, Palasik Mária, Sipos Levente, Szücs László, T. Varga György. Budapest, 1997.

Shvoy Kálmán titkos naplója és emlékiratai. 1918-1945. S. a. r., bev., jegyz.: Perneki Mihály. Budapest, 1983.

Shvoy Lajos: Önéletrajz. Szerk., bev., jegyz.: Mózessy Gergely. Székesfehérvár, 2002. 
Sulyok Dezső: Két éjszaka nappal nélkül. Ford. K. Vladár Edit. Budapest, 2004.

Vas Zoltán: Viszontagságos életem. Budapest, 1980.

Vas Zoltán: Akkori önmagunkról. Budapest, 1982.

\section{Szakirodalom, feldolgozások}

20. századi magyar történelem. Szerk. Pölöskei Ferenc - Gergely Jenő - Izsák Lajos. Budapest, 1997.

Az 1949. szeptember 16-ra összehívott országgyülés almanachja. 1947. szeptember 16. - 1949. április 12. Főszerk. M. Kiss József, Vida István. Budapest, 2005.

A magyar parlament. 1944-1949. Szerk. Hubai László, Tombor László. Budapest, 1991.

Balázs György: Balogh István. In: Politikuspályák. Szerk. Sánta Ilona. Budapest, 1984. $233-243$.

Balogh Margit: Elvetélt fordulatok az egyházpolitikában. Kísérletek a nemzeti katolikus egyház megteremtésére Magyarországon. In: Évkönyv. 1992. Szerk. Bak János. Budapest, 1992. 227-241.

Balogh Margit - Gergely Jenő: Egyházak az újkori Magyarországon. 1790-1992. Budapest, 1996.

Balogh Margit: Mindszenty József. Budapest, 2002.

Balogh Margit: Mindszenty József veszprémi püspök nyilas fogságban. In: Újragondolt negyedszázad. Tanulmányok a Horthy-korszakról. Szerk. Miklós Péter. Szeged, 2010. 233-248.

Balogh Margit: Mindszenty József prímás-érsek és az államforma kérdése 1945-1946ban. Magyar Egyháztörténeti Vázlatok, 22. (2010) 3-4. sz. 111-126.

Balogh Sándor - Izsák Lajos: Pártok és pártprogramok Magyarországon. 1944-1948. Budapest, 1977.

Balogh Sándor: Parlamenti és pártharcok Magyarországon. 1945-1947. Budapest, 1975.

Balogh Sándor: Választások Magyarországon. 1945. A fővárosi törvényhatósági és a nemzetgyülési választások. Budapest, 1984.

Bánfi Szilvia: Tragikus nyomdász sorsok, megsemmisült nyomdák. Magyar Könyvszemle, 121 (2005). 4. sz. 449-463. 
Bauquet, Nicolas: A Mindszentyzmus. In: A magyar jobboldali hagyomány. 19001948. Szerk. Romsics Ignác. Budapest, 2009. 534-555.

Berend T. Iván: A szocialista gazdaság története Magyarországon. 1945-1968. Budapest, 1976.

Berényi Sándor: A magyar népi demokratikus állam közigazgatása. 1944-1945. Budapest, 1987.

Bölöny József: Magyarország kormányai. 1848-1992. Budapest, 1992.

Csanád egyházmegye jubileumi évkönyve. 1980. [Szerk. Szilas József.] Szeged, 1980.

Csizmadia Andor: A nemzeti bizottságok állami tevékenysége. 1944-1949. Budapest, 1968.

Csukovits Enikő: Források, müfajok, lehetőségek: a középkori Magyarország-kép elemei. Korall, 10 (2009). 38. sz. 5-29.

Dancs József: Dobi István. In: Politikuspályák. Szerk. Sánta Ilona. Budapest, 1984. 100-112. 233-243.

Donáth Ferenc: Demokratikus földreform Magyarországon. 1945-1947. Budapest, 1969.

Erdő Péter: Plébánia és egyházközség a háború előtti Magyarországon. Magyar Egyháztörténeti Vázlatok, (1997). 3-4. sz. 91-97.

Erős Vilmos - Gyimesi Pálma: Ifjabb Révész Imre levelei Szekfü Gyulához (19291937). Lymbus, 2009. Főszerk. Ujváry Gábor. Budapest, 2009. 233-258.

Farkas Csaba: A szovjet megszállástól a fordulat évéig. In: Szeged története. 5. köt. 1945-1919. Szerk. Blazovich László. Szeged, 2010. 87-110.

Fazekas Csaba: Kisegyházak és szektakérdés a Horthy-korszakban. Budapest, 1996.

Feitl István - Palasik Mária: Magyar köztársaság. 1946. In: Demokratikus köztársaságok Magyarországon. Szerk. Feitl István, Gellériné Lázár Mára, Kende János. Budapest, 2007. 73-129.

Föglein Gizella: Államforma és államfői jogkör Magyarországon. 1944-1949 Budapest, 1993.

Föglein Gizella: Az államfő intézménye Magyarországon a második világháború után. Budapest, 1994.

Föglein Gizella: Az államfői intézmény és a az Ideiglenes Nemzetgyülés. In: Az Ideiglenes Nemzetgyülés és az Ideiglenes Nemzeti Kormány. 1944-1945. Szerk. Feitl István. Budapest, 1995. 137-150. 
Földesi Margit - Szerencsés Károly: Halványkék választás. Magyarország - 1947.

Budapest, 2001.

Földesi Margit - Szerencsés Károly: A megbélyegzés hatalma. Pfeiffer Zoltán. 19001981. Budapest, 2003.

G. Tóth Ilona: Szeged-Alsótanyától Mórahalomig. In: Mórahalom. A település földje és népe. Szerk. Juhász Antal. Mórahalom, 1992. 103-135.

Gantner Péter: Egy elfelejtett államfő. Zsedényi Béla életpályája. Budapest, 2008.

Gergely Jenő: A katolikus egyház Magyarországon. 1944-1971. Budapest, 1985.

Gergely Jenő: Katolikus egyház, magyar társadalom. 1890-1950. Budapest, 1989.

Gergely Jenő: Az 1950-es egyezmény és a szerzetesrendek feloszlatása Magyarországon. Dokumentumok. Budapest, 1990.

Gergely Jenő: A katolikus egyház Magyarországon 1944 után. Budapest, 1991.

Giczi Zsolt: Szeged katolicizmusa az 1930-as években. Szeged, 1990-91. 12-13. sz. $20-27$.

Giczi Zsolt: Az 1938-as Szent István jubileumi év Szegeden. In: Tanulmányok Csongrád megye történetéből. 24. köt. Szerk. Blazovich László. Szeged, 1997. $67-160$.

Gyarmati György: A parlamentarizmus korlátai és annak következményei az Ideiglenes Nemzetgyülés tevékenységére. In: Az Ideiglenes Nemzetgyülés és az Ideiglenes Nemzeti Kormány. 1944-1945. Szerk. Feitl István. Budapest, 1995. 152-170.

Gyurgyák János: Ezzé lett magyar hazátok... A magyar nemzeteszme és nacionalizmus története. Budapest, 2007.

Haas György: Diktatúrák árnyékában. Tildy Zoltán élete. Budapest, 2000.

Haas György: Balogh páter. A huszadik század Fráter Györgye. Szeged, 2010.

Habermann Gusztáv: Személy adattár a szegedi polgárcsaládok történetéhez. Szeged, 1992.

Hal'ko, Jozef: A csehszlovák szakadár Katolikus Akció. Kommunista kísérlet a katolikus egyház nemzeti egyházzá formálására Csehszlovákiában. EsztergomPiliscsaba, 2004.

Horváth Etelka - Modok Balázs: A kiskunhalasi nyomdászat, sajtó és könyvkiadás történetéről. In: Kiskunhalas története. 3. köt. Szerkesztette Ö. Kovács József, Szakál Aurél. Kiskunhalas, 2005. 419-420.

Högye Mihály: Hogyan mondott le Nagy Ferenc. In: Nagy Ferenc miniszterelnök. Szerk. Csicsery-Rónay István. Budapest, 1995. 90-100. 
Ignácz Károly: Az 1945. évi választások Budapesten. In: Tiltott történelmünk 19451947. Szerk. Horváth János. Budapest, 2006. 44-55.

Izsák Lajos: Polgári ellenzéki pártok Magyarországon. 1944-1949. Budapest, 1982.

Izsák Lajos: A Keresztény Demokrata Néppárt és a Demokrata Néppárt. Budapest, 1985.

Izsák Lajos: A koalíció évei Magyarországon. 1944-1948. Budapest, 1986.

Izsák Lajos: Rendszerváltástól rendszerváltásig. 1944-1990. Budapest, 1998.

Kádár Zsuzsanna: Az SZDP beolvasztása. In: Fordulat a világban és Magyarországon.

Szerk. Feitl István, Izsák Lajos, Székely Gábor. Budapest, 2000. 271-280.

Kanyó Ferenc: A Független Kisgazdapárt újjászerveződése Csongrád megye területén 1944-45-ben. In: A Móra Ferenc Múzeum Évkönyve, 1972-73. 1. köt. Szeged, 1973. 295-310.

Kiss Mária Rita: Bangha Béla sajtókoncepciója politológiai szempontból. In: Állam és egyház a polgári átalakulás korában Magyarországon. 1848-1918. Szerk. Sarnyai Csaba Máté. Budapest, 2000.146-156.

Kisházi-Kovács László: A városi kegyuraság Szegeden. 1917-1948. Budapest-Szeged, 2001.

Klettner Csilla: Balogh István páter politikai pályája. In: Korrajz, 2002. A XX. Század Intézet Évkönyve. Budapest, 2004. 96-127.

Korom Mihály: A népi bizottságok és a közigazgatás Magyarországon. 1944-1945. Budapest, 1984.

Korom Mihály: Magyarország Ideiglenes Nemzeti Kormánya és a fegyverszünet. Budapest, 1992.

Korom Mihály: Az Ideiglenes Nemzetgyülés és az Ideiglenes Nemzeti Kormány létrejöttének hazai és nemzetközi körülményei. In: Az Ideiglenes Nemzetgyülés és az Ideiglenes Nemzeti Kormány. 1944-1945. Szerk. Feitl István. Budapest, 1995. 29-50.

Kovács Tamás: Egy elfelejtett földreformtervezet 1945-ből. Archivnet. XX. századi

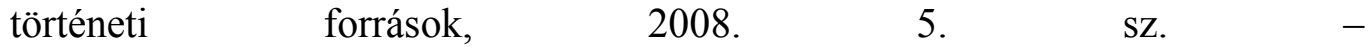
http://www.archivnet.hu/pp_hir_nyomtat.php?hir_id=132 (A letöltés időpontja: 2011. november 19.)

Lotz Antal: Glattfelder Gyula, az egyházfő és tudós. Vigilia, 48 (1983). 2. sz. 142-143.

Lukács Tibor: A magyar népbírósági jog és a népbíróságok. 1945-1950. Budapest, 1979. 
M. Kiss József - Szabó Róbert: Balogh István. In: Az 1949. szeptember 16-ra összehívott országgyülés almanachja. 1947. szeptember 16. - 1949. április 12. Főszerk. M. Kiss József, Vida István. Budapest, 2005. 30-31.

M. Somlyai Magda: Szabadulás és magvetés. Az 1945-ös földreform történetéböl. Budapest, 1961.

M. Somlyai Magda: Földreform. 1945. Tanulmány és dokumentumgyüjtemény. Budapest, 1965.

M. Somlyai Magda: Dinnyés Lajos. In: Politikuspályák. Szerk. Sánta Ilona. Budapest, 1984. 257-266.

Miklós Péter: Város, egyház, társadalom. Tanulmányok a szegedi katolicizmus történetéről. Szeged, 2004.

Miklós Péter: Balogh páter, a szeged-alsóközponti plébános (1933-1946). Magyar Egyháztörténeti Vázlatok, 16 (2004). 3-4. sz. 125-154.

Miklós Péter A páter és a hírlap. Balogh István politikai pályájának kezdetei és a Délmagyarország. In: A Móra Ferenc Múzeum Évkönyve. Történeti Tanulmányok - Studia Historica. 10. kötet. Szerk. Zombori István. Szeged, 2007. 167-192.

Miklós Péter Balogh István és a sajtóügyek (1944-1945). Belvedere Meridionale, 21 (2009). 3-4. sz. 53-60.

Miklós Péter: A Kecskeméti Lapok a koalíciós években (1944-1949). In: A Móra Ferenc Múzeum Évkönyve. Történeti Tanulmányok - Studia Historica. 13. kötet. Szerk. Zombori István. Szeged, 2010. 377-388.

Miklós Péter: A koalíciós évek állama. 1944-1945. In: A magyar állam története. 17112006. Szerk. Szabó Pál Csaba. Szeged, 2010. 205-222.

Miklós Péter: Máriavita ókatolikus püspöki pásztorlevél 1945-ből. Magyar Egyháztörténeti Vázlatok, 22 (2010). 1-2. sz. 159-168.

Miklós Péter: A szegedi bölcsészkar Radnóti Miklós diákéveiben. Tanulmányok Radnótiról, kortársairól és a szegedi egyetemről. Szeged, 2011.

Miklós Péter: Balogh István és a földreform. Acta Universitatis Scientarium Szegediensis. Acta Historica. Tomus CXXXIII. Szerk. Marjanucz László. Szeged, 2011. 51-60.

Molnár Antal - Szabó Ferenc SJ: Bangha Béla SJ emlékezete. Budapest, 2010.

Nehéz esztendők krónikája. 1949-1953. Szerk. Balogh Sándor. Budapest, 1986. 
Pál József: A Hitvallás története. Szegedi Könyvtári Mühely, 26-28 (1987-89). 1-4. sz. $80-115$

Pál József: Békepapok. Katolikus békepapok Magyarországon. 1950-1989. Budapest, 1995.

Palasik Mária: A jogállamiság megteremtésének kísérlete és kudarca Magyarországon. 1944-1949. Budapest, 2000.

Palasik Mária: Kovács Béla. 1908-1959. Budapest, 2002.

Papp Gyula: Az igazoló eljárások és a háborús bünök megtorlása 1945 után Magyarországon. Aetas, 24 (2009) 2. sz. 162-179.

Pelle János: Balogh páter, a koalíció „szürke eminenciása” Valóság, 54 (2011). 4. sz. 92-96.

Péter László: A szerette város. Írások Szegedről. Budapest, 1986.

Péter László: A Város cselédje. Válogatott írások. Szeged, 2006.

Pintér István - Szabó Bálint: A népfrontmozgalom Magyarországon. Történeti áttekintés. Budapest, 1978.

Rákosi Mátyás: A békéért és a szocializmus építéséért. Budapest, 1951.

Rákosi Sándor: Az MKP és az MDP szervezeti felépítése. 1944-1956. Budapest, 1968.

Romsics Ignác: Magyarország története a XX. században. Budapest, 2000.

Romsics Ignác: Az 1947-es párizsi békeszerződés. Budapest, 2006.

Ruszoly József: Három borsodi örökhagyó. Palóczy László, Szemere Bertalan, Zsedényi Béla. Miskolc, 1992.

Ruszoly József: A Város és polgára. Szeged, 1999.

Szakács Sándor: Nagy Ferenc. In: Nagy Ferenc miniszterelnök. Szerk. Csicsery-Rónay. Budapest, 1995. 35-43.

Szeghalmi Elemér: Keresztény küzdelmek és megtorpanások. Az Új Ember 1945-1956 között. Budapest, 2000.

Szerencsés Károly: Predesztinált választások. 1947. In: A magyar parlament. 19441949. Szerk. Hubai László és Tombor László. Gulliver Kiadó, Budapest, 1991. $105-142$.

Szerencsés Károly: Petíciós per. 1947. Valóság, 47 (2004). 12. sz. 43-49.

Szerencsés Károly: A nemzeti demokráciáért. Sulyok Dezső. Pápa, 1997.

Tamasi Mihály: A szegedi gazdapolitikus, Nagyiván János. 1893-1961. Szeged, 2009.

Tóth István: A Nemzeti Parasztpárt története. 1944-1948. Budapest, 1972. 
Urbán Marianna: Balogh István politikája és publicisztikája 1944-1946-ban. Szeged, 2006. Szakdolgozat. (Kézirat, SZTE BTK.) Témavezető: Miklós Péter.

Vida István: A Független Kisgazdapárt politikája. 1944-1947. Akadémiai Kiadó, Budapest, 1976.

Vida István: Koalíció és pártharcok. Budapest, 1986.

Vida István - Vörös Vince: A Független Kisgazdapárt képviselői. 1944-1949. Budapest, 1991.

Z. Karvalics László: A malacvilágosság ideje... Félszázéves sajtótanulságok nyomában. A sajtószabadság korlátai. 1944-1948 In: A hír értékei. Szerk. Csermely Ákos, Sükösd Mihály. Budapest, 2001. 105-118.

Adatközlök (oral history interjúk)

Barlay Ö. Szabolcs (*Kassa, 1919. október 31.) katolikus pap, egykori ciszterci szerzetes.

2009. szeptember 24 .

Gyulay Endre (*Battonya, 1930. szeptember 17.) kiérdemesült szeged-csanádi püspök. 2010. október 6.

Horváth János (*Cece, 1921. november 7.) közgazdász, politikus. 1945 novemberétől 1947. januári letartóztatásáig kisgazda nemzetgyülési képviselö.

2007. augusztus 28

Kovács K. Zoltán (Magyaróvár, 1924. március 27. - 2008. március 6.) agrárszakértő, politikus. 1947 szeptemberétől 1949. februári emigrálásig a Demokrata Néppárt országgyülési képviselője. 2007. április 21.

Paskai László (*Szeged, 1927. május 8.) bíboros, kiérdemesült prímás, esztergombudapesti érsek.

2011. április 12 . 


\section{FÜGGELÉK}

\section{BALOGH ISTVÁN PARLAMENTI BESZÉDEIBŐL (DOKUMENTUMKÖZLÉS)}

Balogh István 1944 és 1947 között a parlamentben csak ritkán szólalt föl. Általában csak technikai, illetve ügyrendi kérdések kapcsán beszélt (például válaszadás a kormányfő nevében egy interpellációra, vagy egy politikai bizottsági határozat ismertetése).

Balogh páter itt közölt parlamenti fölszólalásai az 1947 utáni időszakból valók. Korábban álláspontját a kormányüléseken, a pártközi értekezleteken, illetve a sajtó nyilvánossága előtt fejtette ki. Az államtitkári székből való távozása után politikai müködésének hangsúlyosabb terepe lett - továbbra is aktív publicisztikai tevékenysége mellett - a törvényhozás.

Az első beszéd 1947. október 28-án hangzott el, amikor még a Magyar Függetlenségi Párt politikusai - Pfeiffer Zoltán és képviselőtársai - is ott ültek az ülésteremben. Balogh - „lojális ellenzéki” beszédmódban fogalmazott - fölszólalása bekiabálásokra sarkallta az ellenzéki képviselőket. Ekkor még formálisan szabadon nyilváníthattak véleményt a képviselők.

A dokumentumközlésben olvasható további három beszéd már a pártállami struktúra kiépülése utáni időkből való. Látszik rajtuk, hogy tartalmukat előre egyeztették, s az országgyülési naplót olvasva az is egyértelművé válik, hogy a fölszólalások tartalmában nincs különbség (mind üdvözli a kormány döntéseit), inkább csak a megközelítésben vannak eltérések (így például egy-egy törvényjavaslat esetében különböző társadalmi rétegek reprezentánsai - munkás, szövetkezeti fölműves, értelmiségi stb. - kaptak szót, Balogh páter ilyenkor a polgári politikus, illetve a keresztény lelkész karaktert töltött be). A törvényhozás müködése 1949 őszétől szinte jelképessé vált, hiszen az érdemi jogalkotás szerepkörét a Népköztársaság Elnöki Tanácsa vette át, s a parlament üléstermében érdemi politikai munka nem folyt.

Balogh páter parlamenti beszédeit értelmező és magyarázó jegyzetekkel láttam el. 


\section{1.}

\section{A kormány rendeletalkotásra való felhatalmazásáról Balogh István felszólalása az országgyülés 12. ülésén 1947. október 28-án kedden ${ }^{502}$}

Balogh István (md) ${ }^{503}$ : T[isztelt]. Országgyülés! (Halljuk! Halljuk!) A Független Magyar Demokrata Párt, mind a pénzügyi, mind az általános kormány felhatalmazásokat azok természeténél fogva politikai kérdésnek tekinti, tehát ellenzéki álláspontjánál fogva feltétel nélkül meg nem szavazhatja. Annak a felelösségnek tudatában azonban, amely az országgyülés minden pártjai külön-külön is terheli a Független Magyar Demokrata Pártnak az az elhatározása és álláspontja, amit az országgyülés színe elött kifejezésre juttatni szerencsém van, hogy csak olyan feltétel mellett szavazza meg a felhatalmazást, ha intézményes biztosítékot kap arra, hogy a kormányzásban az országgyülés alkotmányos befolyása érvényre jut. ${ }^{504}$

Pártunk a választási kampány megindulása óta állandóan azt hirdette - és ez az állás-pontja változatlan ma is - hogy konstruktív ellenzék kíván lenni, olyan ellenzéke tehát a kormánynak, amely nem a mindenáron való ellenzékieskedés céljából gördít a kormányzás elé akadályokat, hanem igyekszik azt a lehetőséghez képest befolyásolni és irányítani.

Amint azt pártunk szónoka már a bizottságban kifejezésre juttatta, hajlandók vagyunk a felhatalmazást megszavazni abban az esetben, ha a kormány olyankor, amikor a parlament bármely oknál fogva együtt nem lehet, annak pótlására az országgyülés politikai bizottságát veszi igénybe. Semmiképpen nem tudom osztani

\footnotetext{
${ }^{502}$ Az 1947. évi szeptember 16-re összehívott Országgyülés naplója. 1947-1949. 1. köt. Budapest, 1948. 1947. szeptember 16. - 1949. november 24. 543-557.

503 A szövegben előforduló pártok nevének rövidítései: dn - Demokrata Néppárt, f - Magyar Függetlenségi Párt, kg - Független Kisgazdapárt, kp - Magyar Kommunista Párt, md - Független Magyar Demokrata Párt, szd - Szociáldemokrata Párt.

${ }^{504}$ Az 1947. évi XXVI. törvény meghosszabbította 1948 áprilisának végéig kormány felhatalmazását rendeletek alkotására, amelyeket azonban a törvényhozás politikai bizottságának is - igaz, utólag - jóvá kellett hagynia.
} 
Kállai Gyula ${ }^{505}$ képviselőtársamnak azt az álláspontját, amely szerint ő a parlamenti bizottságokat vagy albizottságokat jelentőségükben leértékeli. Tudniillik a parlamenti bizottságokat, albizottságokat maga az országgyülés küldi ki a saját maga képviseletére, tehát ugyanazon milliók nevében és megbízásából, amely milliók akarata hozta létre magát az országgyülést is. Ezzel lényegében nem mondok újat, csak elfogadom, magamévá teszem Barankovics István ${ }^{506}$ t[isztelt]. képviselötársam véleményét, aki október 7-én elhangzott beszédében a következőket mondotta: „Ha pedig a kormány valaminő okból mégis szükségét látná a felhatalmazás meghosszabbításának, akkor azt kérjük, méltóztassanak fontolóra venni, hogy a törvényhozás szerepét legalább annyira kellene méltányolni, mint amennyiben az elmúlt rendszerek tették, amelyek az úgynevezett 36-os bizottságon keresztül biztosították a törvényhozás hatalmának részleges érvényesülését, illetőleg a törvényhozás ellenőri szerepét a rendeleti kormányzás terén."

Valóban, az elmúlt rendszerek 33-as bizottságot, illetőleg később 36-os, majd 42-es bizottságot alakítottak, amely bizottságok olyankor, amikor a parlament összehívása vagy együtt tartása nehézségekbe ütközött, pótolták, helyettesítették, amennyire lehetséges volt, magát a parlamentet. ${ }^{507}$

Nekünk most talán külön bizottságot nem is kellene létesítenünk, mert hiszen megvan a politikai bizottság, amely éppen 36 tagú és a politikai bizottságban az ellenzék, bár arányánál némileg kisebb mértékben, mégis képviselve van, tehát a kormány rendeleti úton való kormányzása ezáltal megszünik, és mégis valamilyen formában a parlamentáris elv is érvényre jut.

T[isztelt]. Országgyülés! Ha valamely képviselő, különösen az ellenzék padsoraiban csak azokra az adatokra támaszkodhat, amelyeket az előadó úr ismertetni szíves volt, az ellenzékiségben csak megszilárdulhat és fokozottabb mértékben érzi, hogy itt nem csak kontrollra ellenőrzésre, hanem a lehetőséghez képest - és ezt ne vegye tőlem rossznéven Barankovics István t[isztelt]. képviselőtársam - fékre is

\footnotetext{
${ }^{505}$ Kállai Gyula (1910-1996) kommunista politikus 1965 és 1967 között miniszterelnök, 1957-től 1989-ig a Hazafias Népfront Országos Tanácsának elnöke.

${ }^{506}$ Barankovics István (1906-1974) kereszténydemokrata politikus, az 1947-es választásokon a - Magyar Kommunista Párt mögött - második legtöbb szavazatot megszerző Demokrata Néppárt főtitkára. 1949 februárjában emigrált.

${ }^{507}$ A parlament politikai bizottsága a törvényhozás ülései között volt a politikai egyezetés és döntéshozás fóruma.
} 
szükség van. Ö nem vállalja a fék szerepét. Ez kissé hálátlan és persze népszerütlen is. De ő azt mondja, hogy (olvassa): „A fékezés taktikáját negatívnak tartjuk és nem tekintjük célravezetőnek. Ahogyan az autót - folytatja Barankovics - a hosszú meredek út után nem fékezéssel vezetjük le, hanem úgy, hogy a motort az első sebességre kapcsoljuk, mert máskülönben a fékek az állandó fékezésben kigyulladnak és elégnek, akként kell majd nekünk is a negatív fékezés helyett motorként bekapcsolódnunk a természetes folyamatba".

Hát itt, az országgyülésben arra kérem igen t[isztelt]. képviselőtársamat, Barankovics Istvánt, engedje meg felhívnom szíves figyelmét két körülményre. Az egyik az, hogy az ellenzéknek a motorhoz vajmi kevés köze van, ahhoz alig tud hozzáférkőzni. A motort vezetni és irányítani a soför feladata. E pillanatban, akármilyen legyen a véleménye Barankovics képviselőtársamnak, a sofőrt mégiscsak Dinnyés Lajosnak $^{508}$ hívják (Derültség. - Pfeiffer Zoltán (f) ${ }^{509}$ : Kék taxi vagy szürke taxi? Egy hang a magyar demokratavárton: Kék taxi!) Vannak, akik talán a zöld taxi után vágyódnak. (Derültség a kormánypártokon. - Pfeiffer Zoltán (f) gúnyosan: Igen, sőt a zöld autó és a rabomobil után is nagyon vágyódnak az emberek!) A másik az, hogy azért a kormány a motort mégsem mindig a lejtőn viszi, hanem van útszakasz, ahol egyenes úton, sőt néha felfelé is viszi és ilyenkor a féknek alkalma van egy kicsit pihenni is és így csökken az a veszély, hogy a fék begyulladjon. (Derültség.)

Nem is egészen reménytelen az ellenzék számára a fék szerepe, mert legyen szabad itt emlékezetébe idéznem Révai József ${ }^{510}$ igen t[isztelt]. képviselőtársamnak egy cikkét, (Zsedényi Béla (f) ${ }^{511}$ : Ő nem szereti a féket!) amelyet augusztus 10-én írt. (Pfeiffer Zoltán (f): Ö eléggé féktelen! - Élénk derültség) Hát abban a szövegben, amelyet én felolvasok, pontosan az ellenkezője nyilvánul meg (Pfeiffer Zoltán (f): Nagy ritkaság!), de ezt is észre kell venni. (Pfeiffer Zoltán (f): Azért könnyü mást

\footnotetext{
508 Dinnyés Lajos (1901-1961) kisgazda politikus, 1947. május 31. és 1948. december 10. között miniszterelnök. Kormányfősége alatt következett be a „fordulat”, azaz a kommunista párt, illetve a Rákosi-csoport hatalomátvétele.

509 Pfeiffer Zoltán (1900-1981) a Független Kisgazdapárt jobbszárnyának emblematikus alakja, majd 1947 márciusától a Magyar Függetlenségi Párt elnöke. 1947 novemberében emigrált.

510 Révai József (1898-1959) kommunista kultúrpolitikus és ideológus, 1947 októberében a Magyar Kommunista Párt parlamenti frakcióvezetője, a külügyi bizottság elnöke.

511 Zsedényi Béla (1894-1955) jogászprofesszor, 1944 decembere és 1945 novembere között az Ideiglenes Nemzetgyülés elnöke. 1947-ben rövid ideig a Magyar Függetlenségi Párt országgyülési képviselője. 1950-ben koncepciós perben életfogytiglanra ítélték, a börtönben halt meg.
} 
tenni!) Tehát augusztus 10-én ezt írta (olvassa): „Mi nem vagyunk mindenáron radikálisok, nem akarunk árkon-bokron át rohanni elöre, azt sem ambicionáljuk, hogy minden kérdésben okvetlenül a mi álláspontunk legyen a legbaloldalibb; tudunk mi megfontoltak, sőt fontolva haladók is lenni; tudunk mi fékezni is, várni is”. Igaz, hogy Révai t[isztelt]. képviselőtársam a választások előtt írta, de gondolom, hogy ezt most is állja. (Derültség. - Révai József (kp): Állja!)

Az előadó úr az államháztartás 1946/47. évi képét erős optimizmussal színezte ki. Úgy tüntette fel, mintha a 3,8 milliárdos bevételben csak 360 millió kölcsön volna benne, tehát mintha a rendkívüli bevételekből csak ennyit kellene az összbevételeknél levonni, holott a 3,8 milliárdban a 380 millió kölcsönön kívül még 414 millió rendkívüli, tehát nem ismétlődő bevétel is szerepel, nevezetesen 245 millió felértékelési nyereség, 83 millió pénzverési nyereség és az amerikai kölcsönből való 44 millió. Ez mind benne foglaltatik. Ha ezeket mind levonjuk a 3,8 milliárdból, úgy, amint az előadó úr azt helyesen megtette a 360 milliós kölcsön tekintetében, akkor a valóságos kép a következő:

Az összes közigazgatási bevétel 3837 millió, a nem ismétlődő rendkívüli bevételek 774 millió, a valódi közigazgatási bevétel tehát 3040 millió. Ezzel szemben a közigazgatási kiadások 3661 millió, vagyis a közigazgatási deficit összesen 600 millió. Ehhez az üzemek deficitje 109 millió, tehát összesen 700 millió a 360 millióval szemben. A beruházások - mindig a Gazdasági Statisztikai Tájékoztatóra hivatkozom, amelynek felelős szerkesztője Vas Zoltán ${ }^{512}$, a Gazdagsági Főtanács főtitkára - a közigazgatási vonalon 121 milliót, az üzemeknél pedig 162 milliót, vagyis összesen 283 milliót tesznek ki. Az előadó úr tehát teljesen tévesen tünteti fel a dolgot úgy, mintha a beruházások fedeznék a deficitet, holott a deficit még ezeknek a beruházásoknak a levonása után is több mint 400 milliót tesz ki. Egyébként is nem lehet az összes beruházási kiadásokat vagyonszaporulatnak minősíteni, mert hiszen a mi számviteli rendszerünkben értékcsökkenési leírás nem történik és így - mondom - nem lehet minden egyes beruházást az állam vagyoni szaporulatának feltüntetni.

Az előadó úr ennél a pontnál hivatkozik arra, hogy a Számszék ${ }^{513}$ jelenítése az ő értesülése szerint ezeket az adatokat pontosan fogja fedezni. Mi azonban még nem ismerjük a Számszék jelentését, tehát azt még figyelembe nem vehetjük. Nagyon

\footnotetext{
${ }^{512}$ Vas Zoltán (1903-1983) kommunista gazdaságpolitikus, 1947-ben a Gazdasági Főtanács főtitkára. 1956 után történelmi ismeretterjesztö könyveket írt, illetve emlékiratain dolgozott.

${ }^{513}$ Számszék = Legfőbb Állami Számvevőszék.
} 
örülünk, hogy a miniszterelnök úr ebben a pillanatban az 1944-es zárszámadásokat terjesztette elö, mert ez azt jelenti, hogy következnek az 1945-ösek és az 1946-osak és végül is az országgyülés számára készülő kimutatások is majd idekerülnek elénk, s akkor tudunk majd részletesen és pontosan hozzászólni a kérdéshez. Már ideje volna a félévenként szokásos jelentéseket benyújtani.

Azokhoz a számokhoz, amelyekét az előadó úr augusztusra és szeptemberre vonatkozólag itt előadott, szintén nem tudunk hozzászólni érdemben, mégpedig azért, mert az előadó úr nem hivatkozik arra, hogy honnan veszi számadatait, tehát csak arra vagyunk utalva, hogy az általa ismert, de meg nem nevezett forrásokból vette és amíg mi is meg nem nézhetjük ezeket, addig álláspontunkat nem fejezhetjük ki, sem pro, sem kontra nem nyilatkozhatunk. Itt van például - ugyancsak a Gazdasági Statisztikai Tájékoztató írja - hogy a MÁSZ ${ }^{514}$ támogatására ennyi meg ennyi, a NIK ${ }^{515}$ támogatására ennyi meg ennyi. Nem tudjuk, hogy ebben a támogatásban tulajdonképpen mi foglaltatik, vajon ez csak a meglevő deficit-e, vagy pedig azon túlmenőleg is valami, amit e pillanatban még nem tudhatunk. Ismétlem, itt akkor tudunk majd nyilatkozni és állást foglalni, ha majd látjuk a számadásokat vagy legalább megtudjuk, hogy az előadó úr honnan vette a magáét és akkor azokat ellenőrizhetjük.

Nagyon örülök az előadó úr ama álláspontjának, hogy hátrányosnak tartja az előadó úr a tőkeképződés körüli nehézségeket és - úgy látom - itt valami bizalmi légkört akar teremteni, hogy az a tőke jobban képződjék. Már most megkérdezhetem, történt-e valami intézkedés atekintetben, hogy a Révai József képviselőtársam által csavargónak nevezett 200 millió forint beletorkolljék a gazdasági életbe. (P. Ábrahám Dezső (md) ${ }^{516}$ : Nem hiszem, hogy olyan nagyon torkoskodnék itt a tőke!) Tényleg szükséges, hogy a kormány mindent megtegyen abban az irányban, hogy a tőke bizalommal legyen, meg ne rettenjen, hogy a tőkét el ne riasszuk, mert a tőke visszavonulásának arányában fog emelkedni az a baj és veszedelem amely a kormányprogramból is kitűnik: a munkanélküliség. De amennyire helyeselni tudom, hogy a kormányprogram két pontban: a 11. és 12. pontban is foglalkozik a

\footnotetext{
${ }^{514}$ MÁSZ = Magyar Állami Szénbányák Rt.

${ }^{515}$ NIK = Nehézipari Központ

516 Pattantyús Ábrahám Dezső (1875-1973) ügyvéd, politikus. 1919-ben a szegedi ellenforradalmi kormány miniszterelnöke, majd Huszár Károly kabinetjében belügyi államtitkár. 1946-ban a Magyar Szabadság Párt, egy évvel később a Független Magyar Demokrata Párt szervezésében vett részt. Élete végéig többször állt rendőrhatósági örizet, illetve megfigyelés alatt.
} 
munkanélküliség kérdésével és akar ezek szerint mindent megtenni, hogy ezt a veszedelmet csökkentse, ugyanúgy rá kell mutatnom arra, hogy csupán rendörségi intézkedésekkel megjavítani a helyzetet aligha lesz lehetséges. (Taps a magyar demokratapárton.)

Rá kell itt mutatnom arra is, hogy még politikai okokból sem tanácsos olyan intézkedéseket tenni most, amelyeknek gazdasági eredménye és kihatása a munkanélküliséget növelik, amelyek tehát ha nem is ebben a pillanatban, de egy-két hónap múlva politikai veszedelmet hoznak, azoknak a csíráit rejtik magukban. (Úgy van! Úgy van! a magyar demokratapárton.) Nekünk tehát most kell megvizsgálnunk minden rendelkezést, azokat is, amelyeket kiadni politikai okokból szükségesnek tartunk, nem fognak-e úgy visszahatni, hogy a gazdasági problémák növelésével, speciel a munkanélküliség növelésével majd később fognak nagyobb mérvű politikai gondokat okozni. (Úgy van! Úgy van! a magyar demokratapárton.)

Már az anyagnak ilyetén tárgyalása is azt mutatja, hogy a felhatalmazási vitában túl sok politikum is foglaltatik és maga az egész komplexus bizony túl sok politikai problémát vet fel. Nem mondhatom például pénzügyi jellegünek azt a tárgyalást, amely immár fél-végrehajtása tárgyában. (Pfeiffer Zoltán (f): Van egy szitakötő pénzügyminiszterünk, aki folyton repül! - Dulin Jenő (kg) ${ }^{517}$ : Mit csináljon?) E pillanatban még nem tudjuk, hogy az ott létesítendő megállapodások milyen mértékben fogják érinteni anyagi helyzetünket. Meggyőződésem, hogy az a bizalmi légkör, amelyet a kormány Moszkva felé nagyon helyesen kialakítani igyekszik kedvezően befolyásolja az ott folyó tárgyalások menetét. A folyamatban levő tárgyalás volumenének felső határa azonban oly nagy, hogy a legkedvezőbb eredmény is, amelyre bizalommal számíthatunk, komolyan fogja befolyásolni pénzügyi helyzetünket.

Pénzügyi helyzetünk megszilárdításainak célja a kormányt a költségvetéssel kapcsolatban olyan rendelkezések kiadására is készteti, amelyek nem pénzügyi, hanem politikai vonatkozásúak. Erre már az előbb is utaltam. A kormány programjának végrehajtásához szükséges gazdasági feltételek megteremtése szintén igényel olyan intézkedéseket, amelyeknek politikai jellege és kihatásai is vannak. Azt mondja a miniszterelnök úr éppen ezzel kapcsolatban, hogy „a hibák, amik vannak, minden téren kiküszöbölendők. Ehhez azonban a bizalmi légkört is helyre kell állítani, valamint a

\footnotetext{
${ }^{517}$ Dulin Jenő (1889-1959) kisgazda, majd kommunista politikus. 1947-ben az igazságügyi minisztérium politikai államtitkára, a kormány rendeletalkotásra való fölhatalmazására vonatkozó törvény előkészítője.
} 
munkafegyelmet minden vonalon.” (Úgy van! Úgy van! az ellenzéken.) Igen, a bizalmi légkör. Van valami mérges anyag a magyar politikai közéletben, a gazdasági életben is, amit ki kell küszöbölni. Ezt megtenni nem az ellenzék kötelessége, hanem a kormányé. Az ellenzék legfeljebb azt teheti meg, hogy segít megteremteni azokat az előfeltételeket, amelyek a kormánynak elvárt intézkedéseit könnyebbé tehetik. Mondjuk tehát: együttes küzdelem minden olyan jelenség ellen, amely az ország demokratikus, békés fejlődését akadályozza.

Pártomnak ezt a szándékát Maár Gyula ${ }^{518}$ igen t[isztelt]. képviselőtársam talán olyannak fogja minősíteni, hogy újra alkalmazhatja hasonlatát arról az ellenzékröl, amely jégveréskor az eresz alá húzódik, míg ők, a valódi ellenzék, bátran viselik a jégverés megpróbáltatásait. Mi azonban vállaljuk ezt a megkülönböztetést, amint vállaltuk az egész választási kampány alatt a szélsőjobboldal felől állandóan „műellenzékinek” minősített ellenzéki álláspontot. Vállaljuk a „hatóságilag engedélyezett ellenzék" epitetonját ${ }^{519}$ is, udvariasságból olyan hatóságok felé, amelyeknek a logika iránt kevés az érzékük. (Derültség a magyar demokratapárton.)

A népszerüségért valóban nem tettünk és nem teszünk egyetlen lépést sem, amellyel akadályoznók az ország sorsának további fejlődését, különösen pedig az újjáépítés tempóját. Mi is tudtunk volna a választási harc hevében légvárakat festeni hallgatóink elé (Pfeiffer Zoltán (f): Ki festett! - Vásáry József (f) ${ }^{520}$ : Ezt mondja meg!) mi is tudtunk volna hiú, soha meg nem valósítható reményeket kelteni. (Vásáry József (f): Ki csinálta ezt! Tessék már konkrétan megmondani! - Az elnök csenget.) Úgy látszik, a lelkiismeret már jelentkezik. (Derültség. - Vásáry József (f): Tessék konkrétumot mondani, ne tessék nyálazni!) Bennünket azonban visszatartott az a súlyos felelősség, amellyel nemcsak választóinknak, hanem az egész országnak tartozunk. Mi tisztában voltunk és vagyunk a beszéd, a szó akusztikájával és rezonanciájával. M tudjuk, milyen hatása van az egyszerü lélekben annak, hogy a kormányt vagy a koalíciót kortescélokból túlságosan vagy éppen indokolatlanul támadjuk. Akkor mi is hozzájárultunk volna ahhoz, hogy a választók egy része a ratifikálás hallatára nyugat felé fordul és onnan már talán egy fehér ló körvonalait is megjelenni látja. (Derültség. -

\footnotetext{
${ }^{518}$ Maár Gyula (1894-1970) kisgazda, majd függetlenségi párti politikus. 1949-ben emigrált.

${ }^{519}$ Epitetonát $=$ jelzőjét

${ }^{520}$ Vásáry József (1890-1975) kisgazda politikus, 1946-ban földművelésügyi minisztériumi államtitkár. 1946-ban kizárták Független Kisgazdapártból, akkor a Magyar Szabadság Párthoz, majd annak föloszlatása után a Magyar Függetlenségi Párthoz csatlakozott.
} 
Pfeiffer Zoltán (f): Azt eléggé szolgálta a képviselő úr a Tanyai Újságban! ${ }^{521}$ A fehér ló misztikumát elég jól szolgálta! ${ }^{522}$ )

A mi pártunk nem vállalta ezt, nem vállalkozott erre. (Pfeiffer Zoltán (f): Hála Istennek, a tanyai nép sem! - Az elnök csenget.) Nemcsak azért, mert tudjuk, hogy a múlt többé vissza nem tér... (Pfeiffer Zoltán (f): Dehogynem: itt van Balogh István! Derültség.) Hát igen t[isztelt]. képviselőtársaim ön előtt bizonyára a jövő áll, én már a múlté vagyok, (Pfeiffer Zoltán (f): Nem!) mert én már abban a korban is vagyok. (Pfeiffer Zoltán (f): Nem, hanem egy új képlet van: koalícióban fék - ellenzékben ék! - Derültség.) Erre még büszke lehetek és mi szeretnénk magunkat kellő távolságban tartani attól az ellenzéktől, amely mindenáron ellenzék. (Vásáry József (f): A mi programunkat magáévá tette a kormány! Tessék elolvasni! - Gúnyos derültség a kormánypártok oldalán.) Ez ténykérdés és ez a derültség nem azt jelenti, hogy igazat adnak a közbeszóló képviselő úrnak. (Szenner József (f) ${ }^{523}$ : Hiába kéredzkedett be a koalícióba, elutasították!) Én soha nem kéredzkedtem. Ha én kéredzkedtem volna, nem tudom, hol ülnék, itt-e vagy másutt. Efelöl tessék nyugodtnak lenni. (Pfeiffer Zoltán (f): Erről Dinnyés Lajos tudna egyet-mást mondani!) Dinnyés Lajos miniszterelnök, úr nem tud mást mondani, mint amit én mondok, mert az az igazság, (Pfeiffer Zoltán (f): A képviselő úr sohasem mondott valótlant?) és nem hiszem, hogy ő másít mondana, mint ami az igazság. (Pfeiffer Zoltán (f): Képviselőtársam sohasem állított valótlant?) Sohasem. Ezt tanulja meg tőlem.

Vállaljuk a Pfeiffer-párt szónokának kifejezését, hogy mi az eresz alá húzódunk akkor, amikor ők a jégverést állják. (Pfeiffer Zoltán (f): Eresz alatt fészkel a fékecske! - Derültség.) De kérdezem: csak magáért az ellenzékieskedésért, csak magáért a jégverésért, okos ember kimegy-e oda a jégre? (Derültség a szociáldemokrata párt soraiban.) Higgye el a Pfeiffer-párt minden egyes tagja, hogy ha az ország érdekében való volna, akkor nemcsak ez a kis párt, amely ebben a kis szektorban itt meghúzza magát, hanem én azt hiszem, ennek a parlamentnek többi pártja is, nemcsak a

\footnotetext{
${ }^{521} \mathrm{Az}$ 1930-as évek közepén Balogh páter az általa alapított és szerkesztett Tanyai Újságról azt hangoztatta, hogy keresztény nemzeti szellemiségü.

${ }^{522}$ Utalás Balogh Istvánnak a két világháború közötti kormánypárti - a fehér lóval jelképezett Horthyrendszert támogató - magatartására. Balogh 1937 tavaszán szeretett volna belépni a kormánypárt (akkori nevén Nemzeti Egység Pártja) szegedi szervezetébe, ám ezt akkor a helyi politikai szereplők ellenezték. ${ }^{523}$ Szenner József (1875-1948) kisgazda, majd függetlenségi párti parlamenti képviselő.
} 
jégverésnek, hanem a mennydörgésnek lés a villámlásnak is nekimenne. (Egy hang a függetlenségi pártról: Ejha!) Bizony! (Derültség a függetlenségi párton.)

Nem hagyhatom szó nélkül azt a támadást, amely a Pfeiffer-párt részéről, illetőleg Vándor Ferenc ${ }^{524}$ képviselőtársam részéről éppen tegnap is ért bennünket. Mert ők minden alkalmat felhasználnak erre és ennek én igen örülök. Tegnap a választási bíróság egy petíciót tárgyalt. (Egy hang a függetlenségi pártról: Nagyon érdekes volt!) A petícióban - képviselőtársaim talán nem ismerik - mi azt állítjuk, hogy az országos lajstromnál történt valami számtani müveleti tévedés - érdekes - a belügyminisztériumban a Pfeiffer-párt javára. (Pfeiffer Zoltán (f): Ilyen sem fordult elő már hónapok óta!) Mégis, mi azt állítjuk, hogy ott tévedés történt vagy az összeadásnál vagy a szorzásnál vagy az osztásnál. (Rudas László (kp) ${ }^{525}$ : Talán a kivonásban!) Ök ezt tagadják. Mit tehet egy alkotmányos érzületű párt? Odaviszi a bíróság elé: ténykérdés, tessék megállapítani, nekünk van-e igazunk, akik ezt mondjuk, vagy nekik-e akik amazt mondják?

Erre azt mondja Vándor Ferenc képviselö úr, hogy a mi ellenzékiségünk abban nyilvánul meg, hogy mi mindjárt az első pillanatban egy másik ellenzéki pártot majdnem testvérpártot mondott - (Derültség a kommunista- és a szociáldemokrata párt soraiban.) - hátba támadunk. (Zaj a függetlenségi párton. - Az elnök csenget.) Miért támadtuk volna hátba? Mi a nyilvánosság előtt, (Zaj.) sőt a bíróság előtt akarjuk a magunk igazát megvédeni. Hol van itt a hátbatámadás? Hol van itt a politikum, amire szintén alkalmat keresett magának Vándor Ferenc képviselötársam - ha már ilyen izgatott Pfeiffer igen t[isztelt]. képviselő társam... (Pfeiffer Zoltán (f): Én olyan nyugodt vagyok! Annyira, megszoktam már ezt!) Nem látszik. (Derültség. - Pfeiffer Zoltán (f): Dehogynem! Sőt még jókedvű is vagyok!) Az megint más! Az izgalom a jókedvüséggel összefér. (Derültség. - Kováts László (dn) ${ }^{526}$ : Szeressétek egymást!)

\footnotetext{
524 Rudas László (1885-1950) kommunista politikus, filozófus, a marxizmus-leninizmus egyik magyarországi rendszerezője. Később a közgazdaságtudományi egyetem megszervezője és rektora, akadémikus.

525 Vándor Ferenc (1906-1988) eredetileg függetlenségi párti, majd kisgazda politikus. 1947-ben a Magyar Függetlenségi Párt országgyülési képviselője. 1947 novemberében emigrált.

526 Kováts László (1913-2000) 1945-től kisgazda, 1947-ben Pfeiffer-párti parlamenti képviselő. A Rákosi-diktatúra idején és 1956 után - a forradalomban való részvétele miatt - politikai okokból bebörtönözték. 1990 és 1994 a Független Kisgazdapárt, majd az Egyesült Kisgazdapárt országgyülési képviselöje.
} 
Tehát, ha már így áll a dolog, akkor hadd mondjam el a következőt. Nem én mondom - a kisgazdapártinak különösen módjában lesz ellenőrizni annak igazát, amit mondok, mert a szegedi főispán ${ }^{527}$ a kisgazdapárt tagja - őtőle származik az az információm, hogy a választások alatt nem a Pfeiffer-párt képviselőjelöltjei, - ezt nem mondom, mert ő sem mondta - hanem agitátorai - ő is így mondta - (Pfeiffer Zoltán (f): Olyan is volt?) olyan agitációval mentek ki a tanyavilágba... (Révai József (kp): Fasisztával! Nevezze nevén a gyereket! - Pfeiffer Zoltán (f): Adja át Révainak a szót, ő ezt jobban tudja előadni! ${ }^{528}$ - Derültség.)

Én a magam igazát, annak védelmét senkire sem bízom, én azt magam vállalom. Nekem nem kellenek segédcsapatok. (Pfeiffer Zoltán (f): Dehogynem!) Tehát azt mondja a szegedi föispán, hogy, ott az agitátorok - hangsúlyozom nem a képviselőjelöltek (Vásáry József (f): Szép elismerés!) - olyan agitációt fejtettek ki, hogy ha ők bekerülnek, akkor itt 24 órán belül egy távollévő nagyhatalom katonasága fogja megszállni az országot. (Pfeiffer Zoltán (f): Miért nem tette meg a büntető feljelentést? Én ha tudtam volna, a büntető feljelentést megtettem volna! $-Z a j .-A z$ elnök csenget. - Farkas Mihály (kp) ${ }^{529}$ : A központjukban adták ki ezt az utasítást, ügyvéd úr! - Pfeiffer Zoltán (f): Ugyan kérem! Hogy lehet ilyet mondani! - Farkas Mihály (kp): Most is ebben a szellemben dolgoznak! - Pfeiffer Zoltán (f): A szerencsi prédikátor megszólalt! - Derültség az ellenzéken.)

EInök: Pfeiffer képviselő urat rendreutasítom! Kérem, tartózkodjék a provokáló közbeszólásoktól! (Farkas Mihály (kp): Fasiszta propagandát csinálnak! Amerikai fegyverekkel akarják megváltoztatni Magyarország belpolitikai helyzetét! Hazaárulók! - Nagy zaj és ellentmondások a függetlenségi párton. - Az elnök csenget. - Pfeiffer Zoltán (f): Ne beszéljen ilyen bolondságot! - Zaj a kommunista párton. - Farkas Mihály (kp): Hazaáruló! - Pfeiffer Zoltán (f) helyéröl felugorva: a padot verve kiáltja: Rendreutasítani! - Az elnök csenget. - Nagy zaj és felkiáltások a függetlenségi párton: Rendre! Rendreutasitani! - Közbeszólás ugyanonnan: Hogy lehet ilyent mondani! - Egy hang a kommunista pártból: Így igaz! - Pfeiffer Zoltán (f ): Elnök úr, tessék

\footnotetext{
${ }^{527}$ Pálffy György (1904-1970) szegedi föispán.

528 Pfeiffer arra utalhat, hogy a vállaltan „lojális ellenzéki” Balogh pártja politikai álláspontja kialakításakor a háttérben egyeztet a kommunista vezetőkkel.

${ }^{529}$ Farkas Mihály (1904-1965) moszkovita kommunista politikus, a Rákosi-diktatúra idején honvédelmi miniszter, valamint - Rákosi, Gerő és Révai mellett - a szükebb pártvezetés tagja. 1947-ben az országgyülés mentelmi bizottságának elnöke.
} 
rendreutasítani, ha azt állította, hogy hazaáruló! - Farkas Mihály (kp): Hazaáruló! Mégegyszer! - Pfeiffer Zoltán (f): Szemtelen, csirkefogó, pimasz! - Folytonos nagy zaj. - Szőnyi Tibor (kp) ${ }^{530}$ a függetlenségi párt felé: Menjenek ki a parlamentből! Pfeiffer Zoltán (f): Nem maguk küldtek be! A magyar nép küldött be, bennünket és nem önök! - Az elnök többször csenget. - Révai József (kp): Szálasit is megválasztották annak idején! - Pfeiffer Zoltán (f): De kicsoda? - Felkiáltások a kommunista párton: A fasiszták! Ugyanazok! - Pfeiffer Zoltán (f): Nézzék meg, hogy hol vannak, a fasiszta ajánlók! ${ }^{531}-$ Az elnök csenget.) Csendet kérek! (Szőnyi Tibor (kp): Aki külföldi utasításra politizál, az igenis hazaáruló! ${ }^{532}$ - Zaj a függetlenségi párton. - Vásáry József (f): Szerencsétlen, kinek van köze a külföldhöz? - Szőnyi Tibor (kp): Maguknak!) Csendet kérek! A szó Balogh István képviselő urat illeti!

Balogh István (md): Arról van szó tehát, hogy amikor ilyen agitációt fejtenek ki az ö agitátoraik, ugyanakkor a parlament minden pártja - úgy hiszem - ennek az országnak a szabadságáért és függetlenségéért küzd. Nem tudom tehát megérteni, miért kellett tegnap Vándor Ferenc képviselötársamnak ilyen támadást intéznie egy tárgyilagos bírói testület előtt ez ellen a párt ellen, amikor politikumról ott szó sem volt. Azt hiszem, ők is ilyen szempontból akarják magukat distanciázni.

T[isztelt]. Országgyülés! A ratifikálás ismételten szóba került a vita folyamán, majdnem minden szónok talált szavakat erről az egész nemzet életére szinte sorsdöntő tényről való megemlékezésre. Én sem tudok ellenállni annak, - éppúgy, mint Erdei Ferenc $^{533}$ képviselőtársam sem tudott ellenállni, - hogy vissza ne emlékezzem demokratikus újjáéledésünk kezdetére, az 1944. év végére és 1945. elejére, a debreceni napokra. Visszaemlékszem arra, hogyan alakult meg az ideiglenes nemzeti kormány, hogyan léptek hivatalba a miniszterek és az államtitkárok, az utóbbiak nem negyvenen és ötvenen, hanem csak tízen: visszaemlékszem arra, hogyan indultunk el hárman ${ }^{534}$

\footnotetext{
${ }^{530}$ Szőnyi Tibor (1903-1949) kommunista politikus, orvos, később a Rajk-per másodrendű vádlottja.

531 Pfeiffer Zoltán arra céloz, hogy a nyilas párt egykori tagjai - mondhatni tömegesen - léptek be a kommunista pártba, s hogy a kommunisták az egykori nyilas dominanciájú választókerületekben nagyon jó eredményeket értek el.

${ }^{532}$ A kommunisták vádolják hazaárulással Pfeiffert, miközben éppen ők azok, akik a megszálló szovjetek utasításait hajtják végre.

${ }^{533}$ Erdei Ferenc (1910-1971) jogász, szociológus, (kriptokommunista) parasztpárti, később kommunista politikus. A Kádár-rendszerben akadémikus, a Magyar Tudományos Akadémia főtitkára.

534 Balogh István mellett Vörös János (1891-1968) és Faragho Gábor (1890-1953) írta alá a fegyverszüneti egyezményt Moszkvában 1945. január 20-án.
} 
Moszkvába a fegyverszüneti egyezmény aláírására, amikor olyan szegények voltunk, hogy a kormány pecsétjét is Moszkvában kellett megcsináltatni.

Ha eszembe jut, hogy mit éreztünk, amikor a nagyhatalmak képviselőinek aláírásával újra visszanyertük nemzeti létünk első feltételeit és ha meggondoljuk, hogy azóta eljutottunk odáig, hogy a fegyverszüneti egyezményből békeszerződés lett, sőt már odáig is, hogy ezt a szerződést a nagyhatalmak ratifikálták, akkor meg kell állapítanunk, hogy az elmúlt nem egészen három év alatt a nemzet a demokratikus fejlődés útján olyan előrehaladást tett, amely nemcsak minden várakozást, hanem minden képzeletet is felülmúlt.

A háborús múlttal való végleges leszámolás, a földreform, az 1945-ös választás, az új államforma, a pénz stabilizációja, diplomáciai és kereskedelmi kapcsolataink kiépítése, elszántságunknak és áldozatkészségünknek olyan heroikus eredményei, amelyek azt igazolják, hogy Debrecenben megtaláltuk a helyes utat, amelyre a nemzetet rá kellett vinni, azt az utat, amelyröl sem külpolitikai tekintetben, sem belpolitikai kérdésekben letérnünk nem szabad.

Ilyen eredmények mellett olyan zökkenök, mint amilyen egyetlen egyszer, május végén előfordult, feleslegesek. Örülök, hogy a demokrata néppárt, amely a maga világnézeti jellegével, szinte szándéka ellenére is könnyen külpolitikai disszonanciát támaszthatott volna, maga követeli a kormánytól, hogy - és ezt idézem Barankovics István képviselőtársam október 7-i beszédéből - (olvassa): „A külpolitikai, kérdésekből minden világnézeti és, minden érzelmi elfogultságot kapcsoljon ki a kormány”. Ha ezt követelésként állítja a kormányzat elé, bizonyára maga is elvként vallja.

De ha már a világnézeti kérdést felvetette, nem hallgathatom el az aggodalmamat - úgy is mint törvényhozó, úgy is mint pap, - amiatt, hogy mint világnézeti párt is szükségesnek látta, külön egyénileg vállalni az egyház képviseletét a magyar parlamentben. (Eckhardt Sándor (dn): Sohasem vállaltuk az egyház képviseletét! Nem vagyunk az egyház képviselői!) Nem hivatkozom arra, hogy ez éppen akkor történt, amikor a francia választás példája szerint ez a legkevésbé időszerü, nem hivatkozom arra, hogy a legilletékesebb testület, a magyar püspöki kar sem tartotta időszerünek egy világnézeti párt jelentkezését, csak hivatkozom arra a korrekt nyilatkozatra, amelyet Barankovics István t[isztelt]. képviselőtársam maga tett itt a parlamentben, amikor a látszatok ellen védekezett. Kár, hogy ezt a látszatot már a választási kampány elején is nem ilyen határozottsággal minősítette tévedésnek. (Felkiáltások a néppárt soraiban: Többször megtette!) Kérem, ő személyében megtette. 
(Felkiáltások a parasztpárt- és a kommunista párt soraiban: Hol? Hol! - Keresztes Sándor (dn) $)^{535}$ : A „Hazánk”-ban és győri beszédében! ${ }^{536}-Z a j .-A z$ elnök csenget.) Én magam láttam olyan körlevelet... (Parragi György (md): De mást mondottak az agitátorok! $\left.{ }^{537}-Z a j.\right)$

Elnök: Csendet kérek! (Közbeszólások a néppárt soraiban.)

Balogh István (md): Kérem, t. képviselőtársam szem elől téveszti, hogy a kettős kereszt Magyarországon ma is benne, van a címerben és nem politikai jelvény és nem vallásos jelvény. (Egy hang a néppárt soraiban: Annál inkább nem kell kihasználni!) Ehhez tehát jogunk volt (Parragi György (md): Mit mondottak az agitátorok? - Pfeiffer Zoltán $(f)$ : Csak kettős kereszt és a halom, ott van a pártelnök...) Csodálom, hogy olyan ingerültséggel fogadják ezt az egészen tárgyilagos közlésemet. (Egy hang a néppárt soraiban: Valótlanság!) Ez nem valótlanság, ezt visszautasítom, mert a saját füleim hallatára egy magát kisgazdapártinak maszkírozott titkár, - nem kisgazdapárti az illető, de a kisgazdapárt színeiben agitált - olyan tiszta, desztillált nyilas frazeológiával dolgozott az önök pártja számára, hogy önöknek bizony ezt akkor... (Taps a kommunistapárt soraiban. - Egy hang a néppárt soraiból: Talán kisgazdapárti ruha volt rajta! - Zaj. - Az elnök csenget.). Ismétlem és folytatom. (Gáspár Mihály (dn) ${ }^{538}$ : Szomorú, hogy egy magyar pap így beszél!)

Elnök: A képviselő urat rendreutasítom.

Balogh István (md): Kikérem magamnak ezeket az ostoba megjegyzéseket. (Csépe Jenő (dn) ${ }^{539}$ : Pedig egy magyar gazda mondta!) Kikérem magamnak egyszer s mindenkorra! (Zaj. - Az elnök csenget.) Tessék elolvasni majd a naplót, mennyire voltam tárgyilagos vagy szubjektív. (Vásáry József (f): Amikor bennünket nyálazott, szépen tárgyilagos volt! - Pfeiffer Zoltán (f): Denunciáló ${ }^{540}$ magatartást vállalt itt a

\footnotetext{
535 Keresztes Sándor (*1919) újságíró 1947 szeptembere és 1948 júliusa között a Demokrata Néppárt országgyülési képviselője. 1989-1990-ben a Kereszténydemokrata Néppárt elnöke, 1990 és 1994 között a Magyar Köztársaságnak az Apostoli Szentszék és a Szuverén Máltai Lovagrend mellé akkreditált nagykövete.

${ }^{536}$ Vö. Hazánk, 1947. augusztus 17.

537 Parragi György (1902-1963) újságíró, 1947-ben a Független Magyar Demokrata Párt alelnöke. A Magyar Nemzet munkatársa, később a Magyar Vasárnap, illetve a Hétfői Hírek főszerkesztője.

538 Gáspár Mihály (1883-1961) gazdálkodó, 1947 és 1949 között országgyülési képviselő (Demokrata Néppárt).

${ }^{539}$ Csépe Jenő (1900-1966) 1947-től 1949-ig a Demokrata Néppárt parlamenti képviselője.

${ }^{540}$ Denunciáló $=$ feljelentő, beáruló
} 
képviselő úr, jobb tudomása ellenére!) Meg kell mondanom, szerény véleményem szerint mégis van ennek a pártnak hivatása és ez az: megkeresni és megtalálni a kibontakozás útját abban az irányban, hogy az egyház és a demokrácia viszonya minél zavartalanabb legyen és egymást támogatva és segítve együttesen szolgálják népünk boldogabb jövőjét...

A franciaországi választásokat kommentálva, azokhoz minden párt sajtója hozzászólt. Méltóztassanak megengedni, hogy némely szempontra én is kitérjek. Ma divatos szó a polarizáció. Tévednek azok, akik azt hiszik, hogy a polarizáció alapja vagy választóvize a világnézet. A most folyó polarizáció kikristályosodási pontjai lehetnek gazdaságiak, lehetnek nagyhatalmiak, lehetnek szociálisak, de semmi esetre sem világnézetiek. Ezért téves az a megítélés, amely a franciaországi „katolikus” párt más pártokba való felszívódásainak okát az egyház gyengülésében látja. Az egyház a maga kétezer éves tapasztalatával soha sem szeretett egyetlen politikai pártba zsugorodni. A legkevésbé volna erre oka Franciaországban, ahol éppen úgy katolikus az a nem tudom - nem ismerem a végleges eredményt - 40 százalék degaulleista vagy az a 30 százalék kommunista vagy az a 20 százalék szociáldemokrata. Miért bízná az egyház a maga érdekeinek képviseletét ott is egy pártra, amikor ezt minden más párt is szívesen vállalja, de legalább is - sérteni nem akarja?

Már ez a körülmény is bizonyítja, hogy a polarizálódás alapja nem a világnézeti különbség. Csak így és nem a külön világnézeti párttal való operálás útján valósulhat meg Barankovics István reménye, amelyhez magam is csatlakozom és vele egyetértek: hogy valamikor majd találkozik a kereszténység, a demokrácia és a szociális gondolat. De ha így elkülönülve jár az egyik vagy a másik, akkor lesz demokrácia kereszténység nélkül és szocializmus demokrácia nélkül. Rajtunk is múlik valami, hogy ez ilyen vagy olyan irányban fog-e fejlődni.

Nemrégen olvastam olyan programot is, hogy: ma a demokráciáért, holnap a szocializmusért. Ahogyan ezért sem lelkesedik mindenki, amazért sem lelkesedhetik mindenki, joga van választani. Mi, azonban azon vagyunk és arra törekszünk, hogy a különböző pártokon belül is valamikor találkozzék ez a hármas egység.

Ismétlem, nem ismerem a pontos számokat, hiszen még nem is érkeztek meg, nem tudom, hogy Párizsban, illetőleg Franciaországban a választás eredményéhez képest milyen mértékben tört elöre a kommunista párt, vagy a szocialista párt és egymáshoz való viszonyuk nagyságra nézve százalékban hogy' aránylik. Érdekes azonban rámutatni és megfigyelni azt a szempontot, hogy ott Párizsban, ahol tehát 
Moszkva expanzív ereje kevésbé érvényesülhet, mint - mondjuk - Varsóban vagy Belgrádban vagy Bukarestben vagy éppen Budapesten is, a kommunista párt szintén, ennyire előretört. És ha igaz az, hogy ma, a XX. század, közepén inkább, mint valaha régen azelőtt, a népek és nemzetek fejlődése nem történik elkülönülten, nem történik anélkül hogy a szomszéd, vagy más népek fejlődése ráhatással ne legyen a többire: el lehetünk készülve, hogy esetileg a most összeült parlamentben is rövidesen valamely aritmetikai változás fog bekövetkezni. (Mozgás. - Rudas László (kp): Kinek a javára? - Derültség.) Visszatérve a miniszterelnök úr beszédére, csatlakozom ahhoz az állásponthoz, hogy a munkafegyelmet meg kell szilárdítani. Téves volna azonban azt hinni, hogy a munka-fegyelmet talán csak és kizárólag az ipari munkásságnál kellene megszilárdítani. (Egy hang a néppárton: A partementben is!) Igenis, meg kell nézni a mezőgazdasági munkaterületeket is, különösen azokon a helyeken, ahol faj települések vannak, és itt ne csak a munkafegyelmet ellenőrizzék, hanem a takarékosságot is, mert igen szomorú jelentések futnak be ilyen helyekről. Nem árt azonban betekinteni a hivatali szobákba sem. Itt nemcsak arra gondolok, hogy a tisztviselők megtartják-e a munkaidőt, hanem különösen arra, hogy milyen bánásmódban részesülnek a felek, akiknek az a végzetük, hogy valamely hatóságnál dolguk van. (Egy hang a néppárton. Tragédia! - Parragi György (md): Ez a szellem nem változott!) Nem mindenki fasiszta, nem mindenki reakciós és síber, aki a hatóságokra rászorul, de mindenki magyar állampolgár, aki a hivatalok fenntartásához hozzájárul és jogában áll azok közremüködését igénybe venni. (Úgy van! Úgy van! - az ellenzéken. - Parragi György (md): Úgy rettegnek a felek, mint azelött!)

Határozott zavart lehet észrevenni a közellátási kérdések megítélésében. A rendezésre irányuló törekvésben egyetértek én is, amiről itt több képviselőtársam is szólt, félek azonban, hogy nehéz lesz a kérdést megoldani akkor, ha például Erdei Ferenc is feltételezi, hogy minden hivatalban jelen van a szakértelem. Nincs jelen! A tapasztalat azt mutatja, mert különben nem tudom elképzelni, mi az oka annak, hogy a kormány ma, október végén még nem lát tisztán a tekintetben, hogyan is állunk a kenyérmagvakkal, hogyan állunk a gabonával, a különböző közszükségleti cikkekkel és az őszi munkákkal. (Mozgás. - Közbeszólás, a néppárton: Fogalma sincs!) A miniszterelnök úr is roppant érdekesen fogalmaz, - bizonyára nem kerülte el képviselőtársaim figyelmét sem - amikor azt mondja, hogy ,a most keletkezett kenyérgabona-hiány". A most, októberben! A kenyérgabona-hiány semmi esetre sem keletkezhetett októberben. Ha volt, megvolt már júliusban vagy augusztusban, mondjuk 
röviden, a választások előtt. (Úgy van! - az ellenzéken.) Akkor a különböző pártok nem a terméseredmény arányában, hanem a rájuk eső voksok arányában ígérték a fejadagot. ${ }^{541}$ (Mozgás. - Egy hang a néppárton: A több kenyér ígérete! - Közbeszólás ugyanott: Több szavazat, több kenyér!) Természetesen a pártok meg lehetnek elégedve a vokssal, de azok nem lehetnek megelégedve a fejadaggal. (Mozgás és derültség az ellenzéken.)

De tovább megyek és azt kérdezem, hogy ha nincs elegendő gabona, akkor miért volt a választás előtt, vagy ha van elegendő gabona, miért nincs a választás után. Attól tartok, hogy ebben a pillanatban senki sincs, aki erre határozott választ merne adni. Hiszen méltóztatnak emlékezni, Révai József képviselő úr is azt mondotta, hogy pánikot nem szabad kelteni, de viszont szépíteni sem szabad. Amikor tehát ilyen lehetőségek vannak, amelyek szerint azt kell komolyan feltételezni,, hogy az illető szépít, és vannak adatok, amelyek mellett fel lehet tételezni, hogy ha nyilvánosságra hozzuk őket, akkor pánik tör ki, ez mindenesetre igazolja azt a feltevésemet, hogy a szakértelem hiánya még itt is, ott is meglehet; mert más okot igazán nem tudnék feltételezni, amely mellett indokoltnak látszanék, hogy bizonytalanságban tartsuk - mondjuk - választóinkat.

Általános megnyugvást kelt a kormányprogramnak az a része, amely a MÁSZ és a NIK deficitjének határidőre való megszüntetését írja elő. Amikor annakidején ezt követeltük és sürgősnek tartottuk, azt mondották, hogy ez a reakció hangja. Most már örülünk neki, inkább később, mint soha - rájövünk arra is, hogy ennek sürgetése nem a reakciónak, hanem a demokráciának van az érdekében. (Úgy van! - a néppárton.) Örülünk, hogy a kormány végre erre az álláspontra helyezkedett és szívesen támogatjuk ebben a kérdésben.

A kormányprogram ötödik pontja a minisztériumok és államtitkárok számának csökkentését is elhatározta. A miniszterek számát valóban csökkentették, de a minisztériumok természetesen most is megvannak, csak éppen más vezetés alatt. Ami pedig az államtitkárok számának csökkentését illeti, (Egy hang a kisgazdapárton: Az is megvan!) ez majdnem a komikum határát súrolja és még most, a legutóbbi kommüniké után is hajlandó vagyok - és azt hiszem, nem minden ok nélkül - javaslatot tenni, hogy a kormány sürgősen dolgozzon ki egyéves tervet az államtitkárok számának

\footnotetext{
${ }^{541}$ A Magyar Kommunista Párt Központi Vezetőségének ülésén Rákosi arra kérte Szobek Andrást (18941986), a közellátásügyi minisztérium államtitkárát, hogy a választások előtti héten ,augusztus 31-ig minden jegyre $1 / 2 \mathrm{~kg}$ lisztet adjon”. PIL 274 f. 3/102. ö. e. 2.
} 
csökkentésére, (Derültség az ellenzéken. - Pfeiffer Zoltán (f): Hároméves tervet!) mert gyorsabban ez, úgy látszik, nem fog menni. (Zsedényi Béla (f): A fele is elég!)

Hasonlóképpen csak helyeselni tudjuk a külföldi - mint a program mondja „kéjutazások” megszüntetését, mert nem lehet egészen normális dolognak minősíteni azt, hogy miniszterek és államtitkárok az év jelentékeny, részét külföldön töltik. (Bencsik Gyula (kg) államtitkár ${ }^{542}$ : Tanulmányúton vannak miniszteri tanácsosok!) Ennek két következménye van. Az egyik az, hogy bebizonyítja azt, hogy hatáskörük kielégítő betöltésére az a segédtitkár is elegendő, aki most távollétükben betölti a helyüket, (Derültség az ellenzéken.) a másik következmény pedig az, hogy ez rendkívül sokba kerül nekünk. Például csak egy miniszter és egy államtitkár, akik folytatólagosan kint vannak már nem tudom mióta, eddig 45000 dollárjába került az államnak. (Mozgás. - Pfeiffer Zoltán (f): És a hadifoglyok 20 forintot kapnak! Húsz forintot nyomnak a markukba! Erre tessék felelni! - Mónus Illésné (szd) ${ }^{543}$ : Nem szórakozásból vannak kint!) Ezenfelül van a rendes fizetésük és ami még külön is jár nekik.

Helyeslem, hogy a kormány a külföldre szökők vagyonát elkobozza és a hároméves terv népjóléti beruházásaira fordítja. Ezzel kapcsolatban azonban azt kell kérnem, hogy minden egyes elkobzási esetet lehetőleg hozzanak nyilvánosságra. (Közbeszólás a néppárton: Babanyecz!) Remélem, hogy a kormány, amikor szökevényekről beszól, nemcsak azokra gondol, akik politikai okokból távoztak az országból, hanem azokra is, akik azért szöknek ki az országból, hogy vagyonukat megmentsék. Az egyik konzulátuson az elmúlt napok egyikén 160-an kértek vízumot. Egy nap alatt 160-an! Keletre egy sem, mind nyugatra! (Mozgás a néppárt soraiban.) Ez kétségtelen bizonyíték amellett, hogy nem sporadikus jelenségről van szó, hanem ez már pszichózis, illetőleg betegség, bizonyos társadalmi vagy gazdasági rétegekben. (Közbeszólás a néppárton: Üldözési mánia!) Csak olyanok teszik ezt, akik ezt az országot telephelynek, meggazdagodási területnek és nem hazájuknak tekintik. Itt maradnak, amíg nyugodtan lehet vagyont gyüjteni, kíméletlenül, kegyetlenül és embertársaik iránt minden érzés nélkül, de mihelyt ez a lehetőség csökken, vagy éppen

\footnotetext{
${ }^{542}$ Bencsik Gyula (1898-1986) kisgazda politikus, 1946 márciusa és 1948 decembere között az építés- és közmunkaügyi minisztérium államtitkára.

${ }^{543}$ Mónus Illésné Koronya Jolán (1890-1960) szociáldemokrata - később kommunista - politikus. 19481949-ben az országgyülés háznagya.
} 
kockázattal jár, nyugodtabb éghajlat alá sietnek, ahol biztonságban folytathatják önző tevékenységüket.

Hol vannak ezek a szökevények attól az ipari munkástól, aki az ostrom után éhezve, rongyosan odasietett a munkahelyére és maga hozta rendbe a gépeket és a gyárat, hogy mindennapi kenyerének megkeresési lehetőségét újra megteremthesse, (Úgy van! Úgy van!) vagy attól a tisztviselőtől, kisiparostól, kiskereskedőtől, aki tudja, mit jelent számára ez az ország, amelyen kívül a nagyvilágon nincsen számára hely? (Úgy van! Úgy van! - a magyar demokratapárton.) De különösen hol vannak ezek a magyar paraszttól, (Úgy van! Úgy van! - a kisgazdapárton és az ellenzéken.) aki még akkor is, amikor nem a saját földjét müvelte, úgy idegyökerezett ebbe a földbe, hogy a legnagyobb viharok is a tölgyet könnyebben tépték ki, mint a legkisebbet, a leggyengébbet közülük.

Mekkora tanulság volt számomra is látni mindazt, ami 1944 októberében történt: menekültek a katonák, a hatóságok, a gazdagok, a földbirtokosok is, de ottmaradt helyén a kisember, akivel szemben pedig sokszor oly mostoha volt ez a haza, és ott maradt, mint bástya, a paraszt. (Ternay István (md) ${ }^{544}$ : Fütyültek a golyók és szántott!) Hozzáteszem, ottmaradt lelkipásztorával, mert a pap ottmarad híveivel. (Egy hang a szociáldemokrata párt, soraiban: Már ahol!)

A parasztság lelke összenőtt a talajjal, annak sajátosságaival, növény- és állatvilágával: a parasztság az a gyökérzet, amely mélyen belenyúl a földbe, gyökérzet, amely a talajt termőfölddé formálja. Ez a gyökérzet keményen, szenvedélyesen, makacsul belekapaszkodik ebbe a földbe, ezért a parasztságnak mindenki másnál sokkal erősebb érzése a szülőföld, a saját földjén megvetett otthon, a családhoz való ragaszkodás. $\mathrm{S}$ mert mindene a föld, minden más osztálynál erősebb, sóvárgóbb a ragaszkodása vagy a vágyakozása a saját tulajdonú föld után. Ez magyarázza meg a parasztság konzervatívabb hajlandóságát is. A paraszt inkább megőrzi népi hagyományait, ragaszkodóbb templomához, iskolájához s aki ahhoz nyúlni merészel, azt ellenségének érzi.

Mostoha volt a parasztság sorsa az évszázadok folyamán. Ezért müveltsége nehezen bontakozhatott ki. Emberi jogi és nemzeti jelentősége szerinti öntudata lassabban fejlődhetett. Felszabadulásának voltak stációi 1836-ban, 1848-ban, de a

\footnotetext{
${ }^{544}$ Ternay István (1894-1987) 1945-től a Független Kisgazdapárt, 1946-tól a Magyar Szabadság Párt, 1947-től a Független Magyar Demokrata Pártparlamenti képviselője. 1948 augusztusában emigrált.
} 
végleges jobbágyfelszabadulást számukra csak a demokrácia hozta meg 1945-ben, a mostani földreformmal.

S most, amikor a svábok kitelepítése folyamatban $\operatorname{van}^{545}$, nem hallgathatom el, hogy a régi, magyar jobbágyság, tehát a parasztság óriási többsége elnyomottabb volt az idegenfajú parasztság egy jó részénél is, így a letelepített svábok kedvezményekben részesültek, maguk választhatták ki a legjobb helyeket a folyók és nagy forgalmú utak mentén, városok közelében. Szorgalmuk és szerencséjük szerint müvelhették és növelhették birtokukat, szabadon költözhettek oda, ahová akartak. Ugyanakkor a magyar jobbágyok uraik vagyontárgyai voltak, nekik dolgoztak, földet nem szerezhettek, uruk birtokának rögéhez voltak kötve. Amikor bekövetkezett az 1848-i nagy jobbágyfelszabadulás, a svábok a legjobb földeken már elhelyezkedtek. Vagyonosak voltak, az önálló gazdálkodás tapasztalataival, gyakorlatával rendelkeztek, óriási előnyben voltak tehát a frissen felszabadult szegény, gyakorlatlan, eladdig jogtalan magyar jobbágysággal szemben.

Ezt az óriási hátrányt száz esztendő alatt sem tudta behozni a jobbágyszármazású magyar paraszti tömeg. Ezért volt általában a különben szorgalmas svábság jobb módú a magyarnál, holott a magyar paraszt értelmessége, szorgalma, sokoldalúsága és különösen igénytelensége a svábokkal szemben minden összehasonlítást, kibírt.

A magyar birtokos parasztságban történelmi okok következményeként nem fejlődhetett ki osztályöntudat és az osztályharcra való hajlandóság. Az osztályharc érzése csupán a földtelen parasztságban vert gyökeret, amire elnyomottsága és sanyarú osztályhelyzete kényszerítette. Tapasztalati tény azonban, hogy ha ez a réteg saját tulajdonú földhöz jut, akkor ő maga is konzervatív hajlandóságú lesz s ez az érzés, ez az ösztön, ez a hajlandóság megvan az újgazdákban is és meg fog erősödni abban a pillanatban, amikor teljes mértékben jogilag is. tényleg is tulajdonosai lesznek a nekik juttatott földnek.

A kiegyezést követő évtizedekben a parasztság, amely az 1848-as eszméknek a legrendíthetetlenebb híve volt, még akkor sem vette programjába a saját osztályérdekeit. Ez a nép volt az igazi „populus Kossuthianus”,546, részben hálából, mert 1848-ban

\footnotetext{
${ }^{545}$ A magyarországi németek kitelepítése a Szövetséges Ellenőrző Bizottság kérésére a 12.330/1945. ME rendelet szabályai alapján történt 1946 és 1948 között, amikor is körülbelül 180000 magyarországi németet kényszerítettek szülőföldjük elhagyására.

${ }^{546}$ Populus Kossuthianus $=$ Kossuth népe, kossuthi nép
} 
felszabadult, részben mert a nemzeti függetlenség vágya az akkor már három évszázados német elnyomatás miatt legmélyebben a parasztság lelkében vert gyökeret. (Parragi György (md): Ez igaz!) Csak a múlt század vége felé törtek ki az elnyomott és borzalmas helyzetben lévő földtelen parasztok agrárszocialista lázongásai, amiket a Mezőfiek, az Achimok és a Szántó Kovácsok szerveztek meg. ${ }^{547}$ Ami azóta történt, az már beletorkollik a napi politikába.

Az új parlamentben a kommunista párt a magyar ipari munkásság és parasztság legnagyobb pártjának nevezte magát. A szociáldemokrata párt hasonlóképpen nagyszámú paraszti voksokra hivatkozik. A nemzeti parasztpárt kizárólag és a független kisgazdapart túlnyomólag ugyancsak a parasztságra támaszkodik. Ha ez így van, ahogyan mondom, - márpedig ellenvetés alig volna elképzelhető - akkor ez az összeállítás garanciáját jelenti annak, ami a nemzet biztos és nyugodt fejlödésének nélkülözhetetlen feltétele, hogy a parasztság rovására semmiféle más osztályérdek nem fog érvényesülni. Ez annál könnyebb, mert az ipari munkásság családfája éppen úgy, mint a középosztályé, az első, de legfeljebb a második fokon már a parasztsághoz ér. A magyar társadalmi osztályok csak testvérek lehetnek, amelyek sorsukat csak együtt biztosíthatják és javíthatják meg. (P. Ábrahám Dezső (md): Azok is faluról jöttek be Pestre!)

Kossuth Lajos állapította meg, hogy a paraszt tartotta fenn magyarnak ezt az országot, s Magyarország nyomban megszünik, ha megrendül parasztsága. (Úgy van! Úgy van!)

Az 1945-ös földreform ezt az országfenntartó parasztságot erősítette meg és tette a demokratikus köztársaság legszilárdabb bázisává. Kell, hogy minden költségvetés és minden felhatalmazás ezt a szempontot figyelembe vegye.

Ismétlem, ellenzéki álláspontomnál fogva a felhatalmazást feltétel nélkül meg nem szavazhatom. Amennyiben a Ház határozatának meghozatala előtt a kormány részéről olyan nyilatkozat hangzanék el, amely a pártunk által feltételként megjelölt politikai bizottság beiktatásait tartalmazná, magam és pártom ezt az álláspontunkat a

\footnotetext{
${ }^{547}$ Agrárszocialista, a nagybirtokrendszer fölszámolását sürgető politikusok. Mezőfi Vilmos (1870-1947) a Magyarországi Újjászervezett Szociáldemokrata Párt vezetője, Áchim L. András (1871-1911) a Magyarországi Független Szocialista Parasztpárt alapítója volt. Szántó Kovács János (1852-1908) hódmezővásárhelyi tevékenysége nagy hatással volt az 1890-es évek délkelet-magyarországi (viharsarki) agrárszocialista mozgalmaira.
} 
szavazásnál korrigálni fogjuk. (Helyeslés és taps a magyar demokratapárton. - Révai József (kp): Benne van a javaslatban!)

2.

\section{A magyar-csehszlovák barátsági szerződésről \\ Balogh István felszólalása \\ az országgyülés 5. ülésén 1949. június 15-én kedden ${ }^{548}$}

T[isztelt]. Országgyülés! A tárgyalás alatt lévő törvényjavaslatot, amely a csehszlovák-magyar barátsági, együttmüködési és kölcsönös segélynyújtási szerződést tartalmazza örömmel üdvözlöm. Ha egy-két szóval kellene kifejeznem véleményemet, azt mondatnám: debuisset pridem, azaz már régen szükséges lett volna ez a szerződés. Nemcsak a legutóbbi évtizedeket és azok megpróbáltatásait viselte volna könnyebben a két szomszédos ország népe, de az évszázadok viharai sem rendítették volna meg annyiszor és annyira országainkat, ha őszinte bizalommal, testvérként ellhettünk volna egymás mellett.

Igen! Ha - amint azt Andics Erzsébet ${ }^{549}$ előadó képviselőnő egészen lenyűgöző modorban és részletesem adta elö - nem lett volna Habsburg-érdek, a Monarchia népeit négy évszázadon át egymás ellen kijátszani! ${ }^{550}$ Helyesen mondja a törvényjavaslat

\footnotetext{
${ }^{548}$ Az 1949. évi június hó 8-ra összehívott Országgyülés naplója. 1. köt. Budapest, 1950. 1949. június 8. 1949. december 22. 87-90.

${ }^{549}$ Andics Erzsébet (1902-1986) kommunista politikus, történészprofesszor, akadémikus.

${ }^{550}$ Vö. Andics Erzsébet felszólalása az országgyülés 5. ülésén 1949. június 15-én kedden. Az 1949. évi június hó 8-ra összehívott Országgyülés naplója. 1. köt. Budapest, 1950. 1949. június 8. - 1949. december 22. 67-72. Balogh páter utalása a következő részre vonatkozik: „Annak ellenére, hogy a közös sors, a közös történelmi helyzet egymásra utalt bennünket, annak ellenére, hogy évszázadokon keresztül közös ellenség ellen kellett harcolnunk, évszázadokon keresztül közös elnyomónk volt - a német Habsburgdinasztia -, annak ellenére, hogy mindkét nép harcolt is szabadságáért és - ha a csehszlovák népi köztársaság alkotmányában büszkén szögezi le, hogy a huszita forradalom tüzte zászlajára először Európában a gondolat szabadságának és a népuralomnak az eszméjét -, úgy mi is elmondhatjuk, hogy a magyar nép is, harcolva az idegen elnyomás ellen, a szabadságküzdelmek ragyogó fejezeteit írta be nemcsak a magyar, hanem nem egyszer az európai történelembe is, - mondom annak ellenére, hogy
} 
indokolása is: a két nép azért nem értette meg egymást, mert az uralkodó osztályok szándékosan szították és élesztették az ellentéteket. Az uralkodó osztályok és hozzátehetjük - az uralkodóház!

T[isztelt]. Ház! A gimnázium nyolc osztályát a Pozsony megyei Nagyszombatban végeztem ${ }^{551}$, és így tapasztalatból mondhatom, hogy mint mindenütt széles e világon, ott is testvérként élt egymás mellett a két verejtékező, dolgozó nép. A középiskolai ifjúság körében is csak elvétve támadtak pillanatnyi ellentétek, pedig az akkori tankönyvek alkalmasak voltak arra, hogy az ifjúságot, túlzott sovinizmusra nevelve, gyülöletet hintsenek a különböző nemzetiségü ifjak között. Akkor talán nem éreztük, de most már tisztán látjuk, hogy bünös kezek, idegen érdekek, számunkra életveszélyes érdekék szolgálatában szították a túlzott sovinizmus és nacionalizmus tüzét.

Ellenségekké kellett tenni a Duna völgyében lakó népeket, hogy a Drang nach Osten $^{552}$ megvalósulhasson. A fasiszta Németország egyenkint győzhette le a keleteurópai népeket, mert a halálos veszedelem fel nem ismerésével nem a közös ellenség ellen, a német támadás kivédésére készültek, hanem apró gyülölködésekben merültek ki és ostoba kárörömmel nézve a szomszéd pusztulását, végül elgyengülve, egyenkint estek bele saját végzetükbe.

Hála Istennek, ez a szerencsétlen korszak végleg lezárult. Ezer éve élünk egymás mellett szeretetlenségben, vetélkedésben; próbáljunk most már testvéri békességben, barátságban élni, bizalommal egymás mellett, egymást megbecsülve, egymást támogatva saját népeink biztonsága és békés fejlődése ércekében.

közös volt a sorsunk, hogy közös volt az ellenségünk, hogy közösek voltak szabadságtörekvéseink és hogy nem egyszer közös fellépéssel eredményékeit is értünk el - gondoljunk csak Bethlen Gábor politikájára, II. Rákóczi Ferenc mozgalmára -, az utolsó száz év folyamán a szerencsétlen, vak nemzeti torzsalkodással, amelyet idegen elnyomóink és belső reakció, uralkodó osztályaink tervszerüen szítottak, sikerült nem egy nagy küzdelmünket végzetes módom elgáncsolni. Gondoljunk 1848/49-re, amikor a magyar és a szomszédos népek szabadságtörekvéseit is Habsburg-dinasztiának azzal sikerült elbuktatnia, hogy egymás ellen uszította ezeket a szabadságra törekvő, jobb sorsért küzdő népeket. Gondoljunk arra, hogy 1867 után a szörnyüséges, fonák, esztelen, ellentmondásokkal teli Osztrák-Magyar Monarchiának az volt az alapja, hogy a Habsburg-dinasztiának sikerült az itt lakó népeket - nem utolsó sorban a magyarokat, szlovákokat és cseheket - egymás ellen uszítania, egymással őket sakkban tartania. (68-69.) ${ }^{551}$ Balogh István 1904 és 1912 között tanult a nagyszombati érseki líceumban.

${ }^{552}$ Drang nach Osten = törekvés Kelet felé. A német keleti kolonizációs politika jelszava az újkorban. 
Némelyek még ma is abban az illúzióban ringatják magukat, hogy a hitlerizmus négy éve végleg halott, a pángermán veszedelem pedig sok évtizedre, talán mindörökre megszünt. Rá kell mutatnunk arra a súlyos tévedésre, amelyet ez az illúzió jelent. Ebben az önámításban él mindenekelőtt a nyugati, különösen az amerikai közvélemény egy része. Ennek a közvéleménynek veszélyérzetét, a második világháború alatt a német imperializmus világhatalmi, törekvéseiről, a náci rendszer embertelenségeiről szerzett szomorú és iszonyú tapasztalatait szándékosan, céltudatosan halványították el, vagy altatták el teljes egészében azok az imperialista, háborús uszító körök, amelyek most újra fel akarják fegyverezni a német militarizmust. Ezek segédkezet nyújtanak a német sovinizmus veszedelmes és Európát már többi ízben lángba borított tüzének felszításához.

Ezek az új háborúra készülő körök a feltámasztott német militarizmust akarják szövetségesül megnyerni és Kelet-Európa ellen faltörő kosul felhasználni. Napról-napra olvasunk Nyugat-Németországról származó nyugtalanító híreket, amelyek új fegyveres alakulatok felállításáról, az ifjúsági Werwolf-mozgalom ${ }^{553}$ terjesztéséről, hírhedt nácivezérek rehabilitálásáról, háborús bünös, kegyetlenkedő tábornokok, SSparancsnokok szabadlábra helyezéséről és reaktiválásáról számolnak be. Ez természetesen veszedelmes játék a tűzzel, egy olyan tüzzel, amelynek nemrég már martaléka lett egész Európa, s amelynek üszkös gerendáit, romjait máig sem lehetett teljesen eltüntetni.

Gyakorlati tapasztalat, t[isztelt]. Ház, hogy aki egyszer tüzkárosult volt, akinek legdrágább értékeit, sőt hozzátartozóit is elégette már egyszer a tűz, az érthetőleg erősen vigyáz a tűzrendészeti elővigyázatossági intézkedésekre, azokat maga betartja és másokkal is igyekezik betartatni; azonnal észreveszi azt is, ha valahol még nem sikerült ártalmatlanná tenni a tűzfészket, és ha tüzveszély forog fenn, magától értetődik, hogy azok a szomszédok, akiknek egyszer már leégett a házuk, összefognak az új közös veszély elhárítása érdekében.

A múlt évi varsói külügyminiszteri konferencia hívta fel teljes nyomatékkal a világ közvéleményének, az országuk sorsát irányító államférfiaknak figyelmét is arra, hogy Európában ismét tüzveszély van, megjelölte ugyanakkor a veszély elhárításának, az ellene való védekezésnek eszközeit és módszereit is. A varsói külügyminiszteri

\footnotetext{
${ }^{553}$ Werwolf-mozgalom = náci ellenállási mozgalom, amely a szövetségesek által megszállt területeken gerilla, illetve terrorista módszereket alkalmazott.
} 
konferencia határozatai konkrét javaslatokat tartalmaztak a német kérdés megoldására, a pángermán veszély, a kelet-európai államokat fenyegető új német nacionalista és militarista expanzió, a német fasizmus újjáéledésének megakadályozására.

T[isztelt]. Ház! A tárgyalás alatt álló törvényjavaslat logikus következménye mind a Németországban veszedelmes arányokban jelentkező tüzveszély konstatálásának, mind a varsói külügyminiszteri konferencia határozatainak. Ugyanaz a nemzeti aggodalom, ugyanaz a politikai elörelátás, ugyanaz az elszánt akarat, az új német Drang nach Ostennel való szembefordulás hozta létre ezt a szerződést, mint a varsói külügyminiszteri konferencia határozatait. De nemcsak az azonos külpolitikai érdek tette szükségessé az előttünk fekvő szerződés megkötését, hanem a magyar és a csehszlovák népnek mélyröl feltörő azonos kívánsága és legfőbb óhaja, vagyis a béke megőrzésének és egy új háborús veszély csökkentésének elszánt akarata is.

Erről a szerződésről tiszta lelkiismerettel mondhatjuk, hogy a szó szoros értelmében véve békeokmány, a békének legfontosabb nemzetközi dokumentuma, nemcsak abban az értelemben, hogy a két szomszéd nép viszályait szünteti meg és testvéri együttélést teremt köztük, hanem békeokmány abban az értelemben is, hogy az általános európai- és így a világ-békét is szolgálja, egy vakmerő, új német agresszió elriasztásához járul hozzá és így szervesen illeszkedik bele a Szovjetunió vezetése alatt álló hatalmas világbéke-offenzíva stratégiájába.

A szerződésnek e békés jellegét egyébként szövege is hangsúlyozza. Az egyezmény II. cikkének második bekezdése szó szerint ezeket tartalmazza (olvassa): „E célból a Magas Szerződő felek részt vesznek minden olyan nemzetközi akcióban, amely a béke és a nemzetközi biztonság megörzésére és megvédésére irályul, és hathatósan hozzájárulnak e cél megvalósításához az Egyesült Nemzetek Alapokmánya elveinek megfelelően.”!

A nagy nemzetközi béke vonatkozásaitól eltekintve a lelki megbékélésnek is hathatós eszköze ez a szerződés. Ennek a szerződésnek a szelleme kétségtelenül kihat majd a két szerződő fél politikai, társadalmi és gazdasági életének minden terére, tehát a Magyarországon élő szlovák és a Csehszlovákiában élő magyar népcsoportok kulturális, gazdasági és társadalmi életére is.

A szerződés bevezetése - mint mondottam - történelmi igazságot tartalmaz, amidőn rámutat arra, hogy a múltban részben saját uralkodó osztályaink, részben pedig 
a német imperializmus „divide et impera ${ }^{554}$ " elve - mint Horváth Márton ${ }^{555}$ képviselőtársam is rámutatott erre - akadályozta meg a két nép jó szomszédi viszonyainak kialakulását. ${ }^{556}$ De ugyanígy a lelki megbékélésnek is útját állta mind a két országban a reakciós sovinizmus. Ennek a reakciós sovinizmusnak káros határai alól szabadította fel a csehszlovákiai magyar népcsoportot az 1948-as februári fordulat, amely megsemmisítette a csehszlovák soviniszta reakciót és diadalra juttatta a népi demokrácia erőit. Ezek az erők odaát is, nálunk is nemcsak a két nép politikai kibékülését teremtették meg, de egyben a lelki megbékélés feltételeit is, amelyek között legelső helyen szerepel ez e történelmi nevezetességü szerződés.

Az elöadottak alapján leszögezhetem felfogásomat, amely szerint a szerződés hathatósan támogatja a nagy nemzetközi békefront törekvéseit, csökkenti egy új német agresszió lehetőségét, megteremti a jószomszédi viszonyt a két egymásra utalt Dunavölgyi nép között és biztosítja a két országban élő magyar, illetve szlovák népcsoport kulturális és gazdasági fejlődését. Éppen ezért a törvényjavaslatot, mint a nemzetközi béke és a belső megbékélés fontos tényezőjét, örömmel elfogadom. (Nagy taps.)

\footnotetext{
${ }^{554}$ Divide et impera = Oszd meg és uralkodj!

555 Horváth Márton (1906-1987) újságíró, kommunista politikus, 1945 és 1950 között a Szabad Nép felelős szerkesztője.

556 Vö. Horváth Márton felszólalása az országgyülés 5. ülésén 1949. június 15-én kedden. Az 1949. évi június hó 8-ra összehívott Országgyülés naplója. 1. köt. Budapest, 1950. 1949. június 8. - 1949. december
} 22. 72-80. - Amire Balogh utal: „A történelem kétségtelenül arra tanít, hogy addig, amíg Magyarországon nem a magyar nép volt uralmon, amíg Csehszlovákiában nem a cseh és szlovák nép volt uralmon, addig kétségtelenül az volt az, alapelv, hogy ezeket a népeket egymás ellen ugrassák. Ez volt a helyzet a Habsburgok uralma alatt. Tudjuk jól, hogy a Habsburgok politikájának vezérlő szempontja az »oszd meg és uralkodjál« volt. Talán egyetlen területen sem sikerült ezt olyan messzemenően keresztülvinniük, mint éppen a cseh és a magyar viszonylatot illetően. A monarchiában a cseheket engedték egy bizonyos iparosodáshoz jutni, ugyanakkor megfosztották őket az állami függetlenség látszatától is. Magyarországnak az osztrák-magyar monarchiában volt egy bizonyos látszat-, részleges állami függetlensége a monarchia keretén belül, ugyanakkor az ipari, a gazdasági fejlődést minden erővel fékezték, korlátozták. Ezért egymás ellen szították, uszították a cseheket és a magyarokat, a szlovákokat és a magyarokat. Tudjuk jól, hogy egy ilyen évszázados »nevelésnek« hallatlan kihatásai vannak magát a népet illetően is. Ugyanezt a politikát, ugyanezt az ellenségeskedést folytatta kétségtelenül Horthy Magyarországa és Benes Csehszlovákiája is. Nem kétséges, hogy Horthy Magyarországa és az akkori kisantant környező államai közül a legerősebb ellentét talián éppen Csehszlovákia és Magyarország között volt." (73-74.) 
3.

\section{Magyarország alkotmányáról}

\section{Balogh István felszólalása}

az országgyülés 10. ülésén 1949. augusztus 17-én szerdán 557

BALOGH ISTVÁN: T[isztelt]. Országgyülés! Nem minden elfogódottság nélkül szólalok fel az előttünk fekvő törvényjavaslat tárgyalásánál. Érzem a történelmi idők szárnycsattogását, érzem a fordulópontot a magyar sors küzdelmeinek útján.

Ugyanaz az érzés fog el, mint amit átéltem 1945. január 20-án, amikor Moszkvában, mint a kormánydelegáció egyik tagja, aláírtam a fegyverszüneti egyezményt, mely új életlehetőséget nyitott meg népünk számára. Ugyanazt érzem, amit két hónappal később éltem át azon a minisztertanácson, amelyen megvalósult a földreform, összezúzva a leghatalmasabb, megdönthetetlennek látszó akadályát annak, hogy a dolgozó magyar nép élvezhesse felemelkedését, jogaiban, kultúrájában, a civilizáció eredményeinek élvezetében való előrehaladását. Ugyanaz az elfogódottság vesz rajtam erőt, amelyet mindannyian éreztünk e teremben 1946. február 1-jén, amikor a demokrácia útján tett elörehaladásunkban szakítottunk a régmúlt századok szellemének megfelelő államformával és kikiáltottuk a köztársaságot.

Most - fordulópontján a nemzet fejlödésének - újra történelmi lépést teszünk.

T[isztelt]. Ház! Akik a Magyar Népköztársaság Alkotmányáról szóló törvényjavaslat tárgyalásánál csak a paragrafusokat vizsgálják, azokat egyenkint boncolgatják, értelmezik vagy magyarázzák, éppúgy nem fogják megérteni magát a törvényjavaslatot, mint ahogyan helytelenül járnak el azok, akik az elmúlt világháborút nem végső eredményeiben vizsgálva, hanem egy-egy csata, ütközet magyarázgatásával szeretnék elbírálni. Akik a gátszakadást, a medrükből kitörő vad hullámok rombolását paragrafusokkal vagy siránkozással akarják megállítani, azok éppúgy tévednek és tehetetlenek maradnak, mint akik a társadalmi ellentéteket és igazságtalanságokat,

${ }^{557}$ Az 1949. évi június hó 8-ra összehívott Országgyülés naplója. 1. köt. Budapest, 1950. 1949. június 8. 1949. december 22. 197-204. 
osztályok elnyomását vagy kizsákmányolását szép szóval vagy intelmekkel óhajtják megszüntetni.

Tény, hogy vannak a törvényjavaslatnak a megszokottaktól eltérő paragrafusai, melyek a konzervatív, a lassú fejlődést szerető elmékben meglepetést váltanak ki, de akik a törvényjavaslatot az évszázadok perspektívájába helyezik, akik ismerik az emberiség fejlődésének szakaszait, a jogfosztásoknak, az elnyomatásoknak és társadalmi osztályok felemelkedésének korszakait, azok nemcsak megértik, hanem örömmel is üdvözlik a javaslatot, mert a dolgozó magyar nép életének régen várt fordulópontját, jobb jövőjének zálogát látják benne.

„Nincs haladás változás nélkül. Nincs alakulás simulás, alkalmazkodás nélkül” mondta Prohászka Ottokár püspök és ugyancsak ő mondja már 1897-ben: „A törzsszervezet emberei harcoltak Szent István rendi alkotmánya ellen. A rendek tusakodtak a demokrácia ellen és a modern demokrácia nyárspolgári része szintén prüszköl minden szociális alakulás ellen. Csakhogy sem az idők kerekét, sem a fejlődés menetét megakasztani nem lehet, az 1000-ik évben éppoly kevéssé, mint 1790-ben, 1848-ban, és biztos indukció alapján állíthatjuk, hogy 2000-ben sem”.

T[isztelt]. Ház! Nem kellett 2000-ig várni. A várakozás idejét fél évszázaddal megrövidítette az a lökés, amelyet 31 évvel ezelőtt adott az emberiség haladásának az orosz forradalom, megteremtve a leghatalmasabb szocialista államot, a Szovjetuniót.

Amikor ipari munkásság még nem volt, a népet a paraszt jelentette. Mi volt századokon át a magyar nép sorsa és élete? A választ nem én adom, hanem Grünwald Béla $^{558}$ „A régi Magyarország” című könyvében: „A paraszt nem részesült jogvédelemben. A parasztnak - írja - nincs közjogi és még magánjogi személyisége sem. A paraszt nem az államnak volt alávetve, hanem a kiváltságos osztályoknak. Az állam a rendekért van, minden az államban a kiváltságos osztályok miatt van. A paraszt fizeti a katonai adót, ő fizeti a nemesség követeinek napidíjait, ő viseli a katonai beszállásolás, az élőfogatok, a közmunka terhét.”

Természetesen a nemesség ezt az alkotmányt védte. Védte saját kiváltságait és megakasztott minden reformot, minden újítást, amely a népen segített volna. És most szóljon újra Prohászka: „Az uralkodó osztály biztosítja magának a törvényhozást, magához ragadja a kormányzatot, iparkodik gazdaságilag kizsákmányolni az elnyomott

\footnotetext{
558 Grünwald Béla (1839-1891) politikus, történész, akadémikus. A régi Magyarország című könyve 1888-ban jelent meg.
} 
osztályokat. Ezért a földbirtokot magának tartja fenn. A többi osztályt birtokszerzésre fel nem jogosítja, a Jogokból egyáltalán kizárja és az állami élet terheit mind reájuk hárítja."

Ha a magyar múltnak ezt a hiteles képét látjuk, magunk előtt, akkor megértjük a forradalmak jogosultságát és tudjuk értékelni, mit jelentett számunkra és az egész emberiség számára az orosz forradalom. Mind e tények ismeretében kérdezem: lehet-e, hogy az, aki az igazság és erkölcs alapján áll, ne fogadja szívesen az előttünk fekvő törvényjavaslatot, mely minden ember számára egyenlőséget hirdeti?! És e jogokat kizárólag a munka, a közösség szolgálatának ellenében adja! Nincsenek többé főurak és főnemesek, nincsenek karok és rendek és nincsenek pénzes iparmágnások. Nincsenek elnyomottak, jogtalanok, de van nemzet! És ez a nemzet most már nem két- vagy háromszázezret számlál, hanem 8-9 milliót, mert teljes jogú tagja minden dolgozó! A magyarság egyetlen gesztussal megszünik vézna, száradó, vérszegény törzs lenni és lesz izmos, életerős, fejlődő tölgy, amely a jövő századokban minden szélnek és viharnak bizton ellenállhat!

T[isztelt]. Ház! Beszédem további részében a törvényjavaslat gondolatmenetét kívánom követni. Bevezető részében a javaslat törvény útján a magyar alkotmányba viszi be és abban örökíti meg a Szovjetunió érdemeit. Helyeslem a hála megnyilatkozásának e formáját, mert egyedülállóak azok az érdemek és áldozatok, amelyeket a Szovjetunió évszázados elnyomatásunk megszüntetése érdekében hozott. De ha csak, a hála érzete kötne bennünket a Szovjetunióhoz, azt nem tartanám elegendőnek. Sokkal több az, ami bennünket a Szovjetunióhoz füz. Mindenekelőtt elismerjük érdemeit, amelyeket az emberiség haladása tekintetében szerzett, megállapítjuk, hogy az ő segítségével részben utolértük, részben elhagytak fejlődésükben a nyugati államokat. Meg kell mondanunk, hogy létérdeket jelentenek számunkra a Szovjetunióval való gazdasági, kereskedelmi és kulturális kapcsolataink. És mindezeken túl, ha mi - ezer esztendeje másokért vérző magyarok - végre a békére vágyunk, csak egy irányba nézhetünk bizalommal ahol meg akarják, meg tudják és meg fogják védeni a békét: a Szovjetunió felé.

„A Magyar Népköztársaság a munkások és dolgozó parasztok állama” - mondja a törvényjavaslat. Tehát nem tesz különbséget fizikai és szellemi munkások között, megszünteti és ledönti a dolgozók közötti válaszfalat, eltörli a kasztrendszert. Az értelmiség különállását felszámolja. Hogy a munkások alatt a szellemi dolgozókat is érti, az nem lehet kétséges, ha figyelmet szentelünk annak az ünnepélyes deklarációnak, 
amelyet a Magyar Függetlenségi Népfront adott ki és amelyben ezt mondja: „A Magyar Függetlenségi Népfront a magyar munkásosztály, a népért dolgozó értelmiség, a dolgozó kisemberek harci és építő szövetsége a leghaladottabb, a legtudatosabb és legkövetkezetesebb társadalmi osztály: a munkásosztály vezetésével."

Ha tehát volnának, akik úgy érzik, hogy a törvény öket név szerint nem említi és így a munkások és parasztok egységéböl, tehát a jogokból is kimaradtak, tévednék. Szeretném ezt a félreértést eloszlatni és szeretném az új alkotmány iránt a szellemi dolgozók körében is azt a bizalmat kelteni, amely a fizikai dolgozókat máris eltölti.

A törvényjavaslat szövegén, kívül és illusztris előadónk beszédének az értelmiségre vonatkozó szövegén kívül idézek néhány nyilatkozatot, amelyet a kormány és parlament illetékes tényezői mondottak az elmúlt idők folyamán.

Éppen Rákosi Mátyás május 14-i beszédében külön kiemelte, hogy a Népfront jelöltjeinek száma 949, ebből haladó értelmiségi 197. Április 19-i beszédében pedig ezt mondja: „Nincs hazánkban egyetlen ember, - legyen kisiparos, kiskereskedo, vagy értelmiségi - aki nem találja meg elhelyezkedését a népi demokrácián belül.”

Gerő Ernő április 13-án ezt mondja: „Nemcsak új pedagógusokra lesz szükségünk, hanem az egyéb magas képzettségü szakembereik további tíz- és tízezreire: mérnökökre, orvosokra, közgazdászokra, könyvelőkre, statisztikusokra, öt év alatt nem kevesebb, mint százezer új magas képzettségü szakemberre lesz szüksége az országnak."

Losonczy Géza július 17-én ezt mondja: „A mi értelmiségünk, tudósaink, íróink, müvészeink arra kapnak buzdítást a népi demokratikus magyar államtól, hogy a dolgozók életét minél szebbé, tartalmasabbá tegyék".

Idézem Kiss Károly cikkét a Szabad Nép augusztus 4-i számából: „Fokozott gondot kell fordítanunk kádermunkánkban a pártonkívüli tehetséges, becsületes, vezetőképes emberekre is. Nekünk az eddiginél sokkal több gazdasági vezetőre, mérnökre, tudósra van szükségünk. Támogatnunk kell és támogatni is fogjuk a pártonkívüli és más párthoz tartozó, a nép ügyéhez hủ szakértelmiséget, hogy képzettségének megfelelö helyen alkothasson".

Úgy gondolom, hogy a törvényjavaslat szövegén túl csak a nyilatkozatok minden érdekelttel megnyugtathatnak, és a javaslat iránt bizalommal töltenek el.

A Magyar Népköztársaságban minden hatalom a dolgozó népé - mondja a javaslat Mekkora utat kellett megtennünk, amíg elérkeztünk ehhez az egyszerü mondathoz I. Ferdinándnak 1548. évi dekrétumától, amelynek 14. cikkelye minden 
alattvalónak a királyi felség iránti engedelmességet teszi kötelezővé! De megtettük ezt az utat, az emberiség fejlődésének nagy szakaszát és nagyon jól tudjuk, hogy a fejlődés útján nem lehet megállni, még kevésbé visszafordulni.

Amint a termelő eszközök magántulajdonban is lehetnék, - folytatja a javaslat úgy a Magyar Népköztársaság elismeri és biztosítja a dolgozó parasztok jogát a földhöz. A munkával szerzett tulajdont az alkotmány elismeri és védi. Megvolt ez már Werbőczy Tri-partitumában is, de milyen másként hangzott: „Minden báró úr, mágnás és nemes a maga munkája, szolgálatai és érdemei által bármiképpen szerzett vagy nyert összes dolgok, fekvő jószágok és birtokjogok felett az atyjával vagy testvéreivel történt osztály előtt mindig szabadon rendelkezhet."

A Népköztársaság alkotmánya mindenkinek munkával szerzett tulajdonát védi, de ugyanakkor kimondja, hogy a magántulajdon és a magánkezdeményezés a köz érdekeit nem sértheti. A későbbi törvényes intézkedések kétségtelenné fogják tenni, melyek azok az esetek, amikor a magántulajdon és a magánkezdeményezés a köz érdekeit sérti. A javaslat. ugyancsak a köz érdekeinek sérelme nélkül biztosítja az öröklési jogot, tehát minden magyar állampolgár becsületes úton szerzett tulajdona a javaslat értelmében és annak szellemében biztosítva van.

Külön kell kiemelnem a javaslatnak azt a részét, amely a munka szabadságának alkotmányos biztosítéka. Minden munkaképes állampolgárnak joga, kötelessége és becsületbeli ügye is, hogy képességei szerint dolgozzék. Amikor az alkotmány ezt a jogot és kötelességet ilyen pregnánsan juttatja kifejezésre, ezzel egyben kötelezettséget is vállal, hogy munkaképes polgárainak munka iránti kötelességük teljesítését minden hatalmával lehetővé teszi és módot nyújt arra, hogy minden munkaképes polgár a maga tisztességes foglalkozása és hivatása keretén belül képességei szerint dolgozzék, boldoguljon és érvényesüljön. Ez a szakasz minden dolgozó ember számára valóban megnyitja a munka és az érvényesülés szabad útját. Amíg a múltban épen azok éltek legnehezebben, akik csak munkájukból éltek és azoknak volt könnyü életük, akik helyett mások dolgoztak, most az életnívó mértéke nem a tőke vagy a spekuláció, még kevésbé a kizsákmányolás, hanem egyedül a végzett fizikai vagy szellemi munka.

A szólás-, sajtó- és gyülekezési szabadság, az egyesülési jog és a vallás szabad gyakorlásának joga, annak alkotmányos biztosítása, különbség nélkül az egész magyar nép évszázados kívánsága. A magyarság legjobbjai harcoltak ezekért a jogokért, amelyeket hosszú időn át lehetett elnyomni, az értük megindult harcokat leverni - mint 1711-ben vagy 1849-ben -, de az emberek lelkéből kiölni nem lehetett soha! 
Ugyancsak alappillére a demokráciának a személyes szabadság és sérthetetlenség biztosítása, a levéltitok és magánlakás tiszteletben tartása. Mindezeket a törvényjavaslat biztosítja.

T[isztelt]. Ház! Méltóztassék megengedni, hogy a javaslat 54. §-ával külön foglalkozzam. E szerint a Magyar Népköztársaság biztosítja a polgárok lelkiismereti szabadságát és a vallás szabad gyakorlásának jogát. A lelkiismereti szabadság biztosítása érdekében a Magyar Népköztársaság az egyházat különválasztja az államtól.

Alig van a törvényjavaslatnak pontja, amely iránt nagyobb volna az érdeklődés, mint az ebben a paragrafusban foglalt elhatározás, az egyház és az állam elválasztása iránt. Ezt a fokozott érdeklődést, mely mindenfelől megnyilvánul, könnyen meg lehet érteni, hiszen közel ezeréves közösséget szüntet meg. Nemzeti életünkben, különösen az első századokban, az egyház és az állam szinte intézményesen összeforrt. Sok olyan feladatot vállalt az egyház, különösen a nép érdekében, amelyet az állam azóta fokozatosan magának ismer el és levesz az egyház válláról. Természetes tehát, hogy az állami élet fejlődésével ezek a kapcsolatok meglazultak, átalakultak, s az egyház és az állam viszonya közeledik a felé az állapot felé, amikor az egyház a teljes szabadság birtokában szolgálja híveinek a lelki üdvösségét és támogatja az államot azáltal, hogy híveit állampolgári kötelezettségeik lelkiismeretes teljesítésére buzdítja, ugyanakkor az állam nemcsak nem emel gátat az egyháznak hivatása teljesítésében, hanem azt a maga részéről elősegíti, sőt támogatja.

Amikor az előttünk fekvő törvényjavaslat az egyház és az állam elválasztását tüzi napirendre, nem elsőnek veti fel a problémát. Ez a kérdés épen olyan régi, mint maga a kereszténység. Amikor a farizeusok megkérdezték a Megváltótól: szabad-e adózni, tulajdonképpen ehhez a kérdéshez nyúltak hozzá. Ezt kívánta rendezni a válasz is, amikor így hangzott: „Adjátok meg a császárnak, ami a császáré, és Istennek, ami az Istené.” Vagyis az embernek vannak kötelességei hazája iránt és vannak kötelességei Isten iránt, mindkét irányú kötelességet teljesíteni kell. Amikor pedig a lázadás vádjával terhelten Pilátus kérdésére az Úr Jézus azt mondotta: „Az én országom nem e világból való!” - kétségtelenné tette, hogy nem lehet a kettő között sem versengés, sem ellentét. $\mathrm{Az}$ elmúlt kétezer év mégis éppen az ellenkezőjét bizonyítja. Hiszen az egyes birodalmak, országok története éppúgy, mint az egyháztörténelem, küzdelmek és kompromisszumok, megegyezések sorozata. Összeütközés kétségtelenül csak akkor keletkezhetett, ha az egyik vagy másik fél idegen területre tévedt, vagy a másikat jogaiban korlátozni akarta. 
Vannak modern országok, amelyekben mindkét fél szigorúan őrködik azon, hogy kettőjük között semmiféle közösség ne legyen - barátságban, békességben megvannak. Az Amerikai Egyesült Államok már kezdeti alkotmányukat így építették fel. De vannak országok, ahol az egyház és az állam elválasztását erős egyházellenes tevékenység, sőt harc előzte meg. Így volt ez Franciaországban, ahol évtizedes szellemi küzdelem előzte meg a törvényt. Éppen a francia példa miatt az egyház az elválasztás tényét ellenséges gesztusnak k minősítheti maga ellen.

Elhiheti a t[isztelt]. Ház, hogy rendkívül súlyos lelkiismereti kérdést kell eldöntenem nemcsak a magam szempontjából, hanem a Ház katolikus tagjai szempontjából, sőt annak a sokmillió katolikus választópolgárnak szempontjából is, akik szavazatukkal a Népfrontot támogatták, és képviseletükben ezt a parlamentet megválasztottak.

Őszintén és nyíltan meg kell mondanom: csak azért tudom megszavazni ezt a törvényjavaslatot, annak 54. §-át, mert kétségtelenül meg vagyok győződve arról, hogy az egyház e törvény életbelépése révén nem rosszabb, hanem jobb, biztonságosabb helyzetbe kerül, melyben hivatását az eddiginél nyugodtabban, szabadabban tudja betölteni. Ismétlem Rákosi Mátyásnak, mint előadónak erről a kérdésről szóló, imént elhangzott szavait: „Demokráciánk, amint ezt gyakran hangsúlyoztuk, a múltban csakúgy, mint a jövőben szívesen kötne kölcsönös megegyezésen és engedékenysége alapuló szerződést. Az egyház érdekei tehát nincsenek veszélyeztetve és jogai érvényesíthetők."

Mivel Rákosi Mátyás nemcsak egy parlamenti párt, hanem a többségi párt vezére, elnöke a Magyar Függetlenségi Népfrontnak, de nemzetközi értelemben is komoly tekintély, akinek nyilatkozata engem is, a parlament többi katolikus tagját is és az egész keresztény magyar közvéleményt is megnyugtatni alkalmas, szavait megnyugvással veszem tudomásul.

Ezévi költségvetésünk tárgyalása alkalmával elmondott beszédemben részletesen ismertettem azokat a jogokat, amelyeket az egyház magának vindikál és a feltételeket, amelyeken belül hivatásait zavartalanul teljesítheti. Kérem a t[isztelt]. Házat és a t[isztelt]. kormányt, hogy amikor az egyház és az állam elválasztásának körülményeit akár külön törvény útján, akár más formában megállapítja az ott felsoroltakat figyelembe venni szíveskedjék.

T[isztelt]. Ház! Mi, magyar katolikus képviselők, az egyház és az állam közeledésének és barátságos találkozásának ügyét szolgáljuk, mert ezt hazánknak is, 
egyházunknak is érdekében állónak tartjuk. XIII. Leó pápa 1894-ben kiadott enciklikájának következő tételét szeretnők megvalósulva látni: „Mindannyiszor, amikor arról volt szó. hogy rendezni kell azokat a kérdéseket, amelyek különböző címeken és indokokból a két hatalmat, az egyházat és az államot érdeklik, a közérdek kívánja és követeli, hogy köztük megegyezés jöjjön létre.” Ennek a közérdeknek kívánunk mi szerény szolgái és szószólói lenni.

T[isztelt]. Ház! Az elmúlt világháború vihara elsodorta a régi alkotmány tényezőit, az országgyülést, a kormányt, az államföt. A jogfolytonosság de facto megszünt. A nemzet életereje, vitalitása új életet fakasztott. Megmozdult a nép minden jog és alkotmány ősforrása, és 1944. december 17-én ideiglenes nemzetgyülést választott. Ez kormányt alakított és létrehozta mindazokat a szerveket, amelyek a nemzet szuverenitását reprezentálják. Új úton indult el a magyar élet. Egy évezred küzdelmei után egyetlenes akaratnyilvánítással megszüntette a régi alkotmány és feudális társadalmi rend utolsó bástyáit. A dolgozó magyar nép, amelynek ez az ország nem hazája, csak keserves, véres-verítékes munkahelye és temetője volt, végre hazát kapott. Hazáját újjáépítette és most már a sajátjában lakva, életnívóját akarja emelni, emberhez méltó testi és lelki jólétben, nyugodt munkáiban és békében. Új alkotmányunk, a törvényjavaslat az eddigi eredményeket és jövő törekvéseinket foglalja magában, ezért Örömmel elfogadom. (Élénk taps.)

\section{4.}

\section{Az első ötéves tervről}

\section{Balogh István felszólalása}

az országgyülés 5. ülésén 1949. december 9-én pénteken ${ }^{559}$

T[isztelt]. Országgyülés! A tárgyalás alatt álló törvényjavaslatnak, a Magyar Népköztársaság első ötéves tervének elfogadására ez a parlament már akkor kapott mandátumot, amikor május 15-én a választók milliói a Népfront képviselőjelöltjeire

\footnotetext{
${ }^{559}$ Az 1949. évi június hó 8-ra összehívott Országgyülés naplója. 1. köt. Budapest, 1950. 1949. június 8. 1949. december 22. 325-332.
} 
adták szavazatukat. Kétségtelen, hogy a választók előtt meghirdetett programban a békéért való kiállás mellett az ötéves terv volt az, amely a mostani országgyülés megválasztását oly impozánssá tette. Most, hogy a törvényjavaslat benyújtásával ennek részletei is nyilvánosságra kerültek, mindannyian megállapíthatjuk, hogy maga az ötéves terv is a béke szolgálatának hatalmas eszköze, a magyar dolgozó nép békés szándékának demonstrációja.

T[isztelt]. Ház! A világ két frontra szakadt. Az egyiken a béke erői küzdenek az emberiség tartós békéjéért, a másik oldalon pedig a pusztítás erői dolgoznak egy harmadik világháború kirobbantásán. Hogy mit jelent a béke és mit jelent a háború, azt kevés nép tapasztalhatta annyira saját nemzeti katasztrófáin, mint éppen a magyar nép. Amikor az emberiség egyik része olyan méretű fegyverkezést folytat, amely a háborús szándék kétségtelen jele, akkor mi magyarok, a békefront szerény, de öntudatos és elszánt tagjai, íme, ötéves népgazdasági tervet készítünk. Mi magyarok, a békeszerető milliók és egyes háborút sürgető csoportok közötti harcban nemcsak földrajzi helyzetünk miatt állunk a béke frontján, hanem különösen a közelmúlt történelmünk tanulságai és el nem felejthető benyomásai következtében is. Láttuk, hogy mit kellett áldoznunk a háború molochjának ${ }^{560} \mathrm{~s}$ láttuk és látjuk nap-nap után, miképp tudunk élni a béke áldásaival, miképp tudjuk felemelni népünk életszínvonalát, építeni, fejleszteni népi demokráciánkat, békés, alkotó munka segítségével. Ezért kell továbbra is megállnunk helyünket nemzeti egzisztenciánk érdekében a világpolitika békefrontján, abban a táborban, amelynek kétségtelen győzelmét a Szovjetunió hatalma és ereje biztosítja. (Nagy taps.)

T[isztelt]. Ház! Ennek a helytállásnak legfontosabb építőeszköze, védőfegyvere az ötéves terv megvalósítása. Az ötéves terv igazi nagy történelmi jelentőségét nemzetünk jelene és jövője szempontjaiból csak azáltal tudjuk megfelelő megvilágításba helyezni, hogy a háború és béke erőinek, azok világraszóló küzdelmének perspektívájában mutatjuk meg, hogy a mi ötéves tervünk nemcsak hazánk dolgozó népe anyagi és szellemi életszínvonalának hatalmas arányú megnövekedését, technikai előrehaladását, iparunk, mezőgazdaságunk, kultúránk soha nem látott fejlődését jelenti, hanem egyben a nemzetközi békefrontnak, a tartós békéért folytatott küzdelmében egyik komoly eszközét is. E terv minden legkisebb alkotórésze a magyarság jobb sorsát hivatott szolgálni. Magasabb életszintet, kényelmesebb,

\footnotetext{
${ }^{560}$ Moloch $=$ az ókori közel-keleti tradícióban a háború és a pusztítás istene.
} 
könnyebb munkát, egészségesebb életkörülményeket, több kultúrát akarunk adni és elérni, tehát mindazt, ami a békés életet szebbé, jobbá, örömteljesebbé teszi.

A magyar nép történelmében, gazdasági, kulturális és szociális életében még nem alkottak olyan átfogó tervet, mely ennyire a legszélesebb és mélyből felfelé törő néprétegek felemelését célozta volna, mint az elöttünk lévő törvényjavaslat. Ami a múltban gazdasági téren történt a nép érdekében, azt mindig az uralkodó osztályok önzése determinálta. Ami kulturális téren történt, az legfeljebb arra irányult, hogy az írni-olvasni tudás statisztikáját javítsa a népek összehasonlító grafikonjában. Szociális téren pedig a dolgozók nem kaptak többet néhány olajcseppnél, amely arra volt jó, hogy az állam politikai gépezete ne nyikorogjon, vagy valamelyik berozsdásodott szelepe robbanást ne okozzon.

Népi köztársaságunk első ötéves terve nemcsak szólam, nemcsak politikai programnyilakozat, hanem valósággá válik a céltól, hogy ,a legfőbb érték az ember!” A bünös háborúkban meggyötört, elvérzett és kifosztott országban is végre ,érték lett az ember". A terv gigantikus méretei lehetővé teszik az ipari munkásság mellett is a falu és benne a dolgozó parasztság szociális helyzetének nagymértékben való megjavítását és különösen figyelmet érdemel az a tétel, amit Vas Zoltán miniszter úr mondott, hogy a terv végrehajtása folyamán 480.000 új munkást és alkalmazottat kell munkába állítani. ${ }^{561}$ Ebben a hazában tehát senki nem lehet munkanélküli - sem fizikai, sem szellemi téren.

T[isztelt]. Ház! Amíg a háború elnémítja a múzsákat, a pusztítás szolgálatába állítja a tudományt, béklyóba veri a szellemet, addig az értelmiség számára korlátlan érvényesülési lehetőséget nyit meg az ötéves terv. Mint ahogy Gerő miniszter úr ${ }^{562}$ a

\footnotetext{
561 Vas Zoltán - nem sokkal Balogh fölszólalása előtt a következőket mondta: „A mezőgazdasági termelés anyagigényessége is megnő. Ez azt jelenti, hogy az intenzívebb gazdálkodást jelentő állattenyésztés fokozása során a mezőgazdaság az általa termelt alapanyagok jelentős részét tovább feldolgozza. A gépesítés és a tervszerüsítés eredményeként a mezőgazdaságban jelentős munkaerők, szabadulnak fel, akik kenyérhez jutnak az iparban. Fontos ez azért, mert az ötéves terv során az iparban 480.000 új munkást és alkalmazottat kell munkába állítani. Az új munkaerők munkába állítása az általános fejlődésnek csak egyik oldala. A másik: a termelékenység fokozása. A népgazdaság technikai színvonalának emelése ugyanis döntő módon kihat a munka termelékenységének alakulására.” Az 1949. évi június hó 8-ra összehívott Országgyülés naplója. 1. köt. Budapest, 1950. 1949. június 8. - 1949. december 22. 274

562 Gerő Ernő (1898-1980) kommunista politikus, a Rákosi Mátyás egyik legfontosabb politikai szövetségese. 1949 decemberében államminiszter, a Népgazdasági Tanács elnöke.
} 
még előttünk álló tudományos feladatokat felsorolta ${ }^{563}$, úgy tudósok, írók, művészek előtt nem volt még annyira nyitva a pálya, nem volt még annyira biztosítva a megbecsülés, mint most. Amíg a háború elkerülhetetlen következménye emberi életek legyilkolása, addig az ötéves terv központi gondolataként hirdeti az emberi értéket. Amíg a háborúban lerombolják a középületeket és a lakóházakat, az iskolákat és a kórházakat, addig ötéves tervünk a meglévőket felújítja és melléjük újakat épít; lesznek új tudományos intézeteink, gimnáziumaink, falusi és tanyai iskoláink, sporttelepeink, kultúrházaink. Amíg a háború elnépteleníti az ország egyes vidékeit, addig az ötéves terv az ország elhagyott részein gyárak létesítésével gazdasági virágzást, elhagyott helyek beépítését vonja maga után. Amíg a háború elszakítja egymástól a családtagokat, addig az ötéves terv a munkanélküliség teljes kikapcsolásával családok alapítását teszi lehetővé. Amíg a háborúban az elégtelen táplálkozás miatt is elpusztulnak a csecsemők, addig az ötéves terv új szülőotthonokat épít, üdülésre viszi a gyermekek százezreit.

Igen t[isztelt]. Ház! Eszek a nagy alternatívák, amelyek nemzetünk előtt állanak, amikor választani kell a háború és a béke frontja között. Az ötéves terv a maga hatalmas koncepciójával, imponáló, tudományosan kidolgozott nagyvonalúságával világosan megmutatja, mit várhatunk a békétől és milyen lehetőségeket valósíthattunk meg, ha a legszorosabb együttmüködésben maradunk a béke erőivel, amelyek a Szovjetunió körül koncentrálódnak.

Az ötéves terv minden rideg számsora ellenére is forró vallomása a magyar dolgozó népnek a béke gondolata mellett. Ugyanakkor megnyilatkozása a humanizmusnak, az emberszeretetnek, mert hiszen minden részletében a dolgozó magyar embert szolgálja. Azt karolja fel a bölcsőtől kezdve, a munkás életen keresztül, egészen a gondtalan öregségig. Ebben a két nagy gondolatban: a béke melletti aktív

\footnotetext{
${ }^{563}$ Balogh páter Gerő Ernő következő gondolataira utalt: „E nagy feladatok megvalósítására jelentékeny beruházásokat kell eszközölnünk tudományos intézeteink helyreállítására, fejlesztésére és új intézetek létesítésére. Ezért ötéves népgazdasági tervünk ilyen beruházásokra kereken 200 millió forintot irányoz elő. Ebben az összegben természetesein nincsenek benne a tudományos intézetek fenntartására és müködésük biztosítására szükséges kiadások, amelyeik nemi az ötéves népgazdasági tervben, hanem a rendes állami költségvetésben szerepelnek. A tervidőszakban új nagy korszerü fizikai intézetet építünk egész sor más új tudományos kutatóintézet mellett. Az újjászervezett Magyar Tudományom Akadémiának meg kell adnunk minden szükséges támogatást, hogy megfelelhessen feladatainak, s hogy mindenekelőtt az ország termelő erőinek fejlesztését szolgáló tervszerü természettudományos és müszaki tudományos kutatás központjává váljék.” Az 1949. évi június hó 8-ra összehívott Országgyülés naplója. 1. köt. Budapest, 1950. 1949. június 8. - 1949. december 22. 279.
} 
kiállásban és a humanizmus megvalósításában láthatja mindenki, aki idealista világnézetet vall, a két legmeggyőzőbb érvet az ötéves terv helyeslésére és támogatására. Ennél a gondolatnál, t[isztelt]. Ház, fel kell hívnom a figyelmet arra, amit Kádár János belügyminiszter úr $^{564}$ keddi beszédében a békefront kiépítésével kapcsolatban mondott. Sajnálom, hogy ismételnem kell, amit Nagy Dániel ${ }^{565}$ képviselőtársam az imént mondott, de én más szempontból kívánom ugyanazt az idézetet, megvizsgálni. „Egy táborba hívjuk a béke védelme érdekében mindazokat, mondotta a belügyminiszter úr - akik a tartós béke hívei. Egyesíteniük kell eröiket a cél érdekében mindazoknak, akik politikai nézetükre, felfogásukra, nemükre, korukra való tekintet nélkül a háborús bujtogatók ellen a béke megvédésének az oldalán állnak. A béke megvédése kérdésében - folytatja - szövetségesünk minden becsületes ember, legyen az bármilyen pártállású vagy pártonkívüli. Az erök tömörítésének feladata a béke védelme érdekében vonatkozik a legkülönbözöbb társadalmi egyesületeikre és az egyházra is."

T[isztelt]. Ház! Ehhez a félre nem érthető egyenes és határozott beszédhez a magam részéröl a következőket füzöm hozzá. A magyar nép amióta a Vörös Hadsereg felszabadította óriási változáson ment át. Az ipari munkásság tudását, munkáját és verítékét nem másokért. hanem a nemzetnek, saját maga jobb jövőjének áldozza. A paraszt végre a maga földjét müveli, és az ipari munkásság mellett részt kapott az államhatalom gyakorlásában. Az értelmiség rövid kábulat után rájött arra, hogy legszebb hivatása a dolgozó népet szolgálni. A kereskedők és iparosok gyakorlati tudásukat, tapasztalataikat fokozatosan ugyancsak a közösség érdekeinek szolgálatába állítják. Vannak még közöttük különbségek, melyek munkájukból, hivatásukból, közvetlen céljaikból, törekvéseikből önként adódnak, de az egész nemzet egyetemes érdekeinek szolgálatában valamennyien egyek. Így vannak magyarok és magyarok között ideológiai különbségek, melyek a különböző pártállásban is megnyilatkozhatnak, a béke kérdésében, azonban mindannyian egyek.

A belügyminiszter úrnak még egy mondatát szeretném kiemelni (olvassa): „Nincs az az egyházi személy, - mondotta - aki a béke védelmének kérdésében nyugodt lelkiismerettel oda ne állhatna a magyar nép elé ebben az igazságos küzdelemben.”

\footnotetext{
${ }^{564}$ Kádár János (1912-1989) 1948 augusztusa és 1950 júniusa között volt belügyminiszter.

565 Nagy Dániel (1910-1982) kisgazda, majd kommunista politikus. 1949 és 1963 között a Népköztársaság Elnöki Tanácsának elnökhelyettese.
} 
T[isztelt]. Ház! Nem lehet kétség a tekintetben, hogy a papság a béke kérdésében milyen álláspontot foglal el. Rákosi Mátyás már ez év május 31-én a választásokon szerzett tapasztalatai alapján ezt mondotta (olvassa): „Megnyilatkozott a demokrácia győzelme a lelkészkedő papság magatartásában, amely követve a dolgozó nép állásfoglalását és saját meggyőződését, csatlakozott a népi demokráciához.”

Ha ez a megállapítás helyes és igaz volt a májusi választás után, akkor bizonnyal fokozottan helyes és igaz ma, amikor a béketábor állandóan növekszik és ahhoz a papság zöme nemcsak a népi demokráciákban, hanem a nyugati országokban is meggyőződéssel csatlakozik. Ennek igazolásául fogadja el a t[isztelt]. Ház Boulier abbénak $^{566}$ a párizsi békekonferencián az ott megjelent papság nevében felolvasott deklarációjának következő szavait (olvassa): „A világ hívő keresztényeit több oldalról szorítják háborúba szovjetellenes keresztes hadjárat ürügye alatt. Jézus Krisztus nevében hívjuk fel őket: gondolják meg, hogy egy ilyen háború súlyos bün lenne Isten és az emberiség ellen, olyan bün, amelyet keresztény lelkiismeret nem vállalhat."

Ha tehát a miniszter úr ${ }^{567}$ most azt mondja - és ez bizonnyal nemcsak egyéni véleménye, hiszen a Tájékoztató Iroda ${ }^{568}$ határozataira, hivatkozik, - hogy magyar emberek, legyenek bár különböző pártokhoz tartozók, legyen bár közöttük politikai vagy gazdasági vagy kulturális kérdésekben véleménykülönbség, legyeinek bár egyházukhoz ragaszkodó, vallásos életet élő emberek, de legyenek a legnagyobb kérdés tekintetében, a háború és béke kérdésének elbírálásaiban a békefront támogatói, mert ebben a kérdésben szövetségesünk minden tisztességes vallásos meggyőződésű ember is, akkor nyugodtan állítom: a magyarság minden tagja egy emberként hüséggel vállalja ezt a szövetséget.

És ha a miniszter úr külön kiemelte a vallásos meggyőződésű embereket, akkor szavait kiegészítve azt kell mondanom, hogy már maga a vallásos meggyőződés kellene, hogy mindenkit a békefront katonájává avasson. Nem is lehet vallásos ember sem egyházi, sem világi - ha ugyanakkor a békének is nem hirdetője, megvalósítója és szolgája. A legjobb meggyőződéssel állítom, hogy a béke megvédésének kérdésében annyira egységes a nemzet, amilyen semmiféle kérdésben nem volt tíz évszázadon keresztül.

\footnotetext{
${ }^{566}$ Boulier, Jean (1894-1980) francia katolikus pap, a kereszténység és a marxizmus közötti párbeszéd szorgalmazója.

${ }^{567}$ Kádár János belügyminiszter.

568 Tájékoztató Iroda = Kommunista és Munkáspártok Tájékoztató Irodája (Kominform).
} 
T[isztelt]. Ház! Ha az idő előrehaladottságai ellenére röviden mégis részletekbe bocsátkozhatom az ötéves terv tárgyalásánál, a magam részéről különösen kiemelendőnek tartom azt, ami a népoktatás céljait szolgálja. A terv 1200 új tanterem létesítését irányozza elő, főleg új kéttantermes iskolákban és az iskolákat rádióval, a fizikai és kémiai oktatáshoz nélkülözhetetlen laboratóriumi felszereléssel is ellátja. A tanyaközpontokban mintegy ezer tanítói lakás is épül. Az egészen kis iskolák 10-14 éves tanulói, akik általános oktatásban ott nem részesülhetnek, tanuló otthonokban nyernek elhelyezést és ezzel biztosítjuk számukra a teljes nyolcosztályos, iskola elvégzését. Javaslom, hogy amint most is meg van engedve, a jövőben is addig, amíg a vallásos dolgozó nép saját erejéből alkalmas helyiségeket állítani nem tud, a tantermek - a dolgozók kérésére - istentiszteleti célokra is használhatók legyenek.

Harminc új gimnáziummal bővül a középiskolai hálózat. Az eddig elhanyagolt ipari és bányavidékeken az ideiglenes elhelyezésű gimnáziumok részére új korszerü, nagy befogadóképességű gimnáziumokat létesítenek. Úgy tudom és helyeslem is, hogy a közgazdasági egyetem részére a fővámpalotát ${ }^{569}$ alakítja át és hozza helyre az ötéves terv. A legtöbb középiskola mellé új kollégiumok épülnek. Gondoskodunk az ötéves terv folyamán szükségessé váló 12.000 új pedagógus kiképzéséről is.

Nem kívánom ezeket a számokat mégegyszer felolvasni, bár nagyon szeretném hangoztatni mindenfelé, éppen azok felé a rétegek felé, amelyek talán még öt év után is bizonyos bizalmatlansággal és félénkséggel vannak a demokrácia fejlődése iránt, hogy bizalommal és hűséggel közeledjenek, de Gerő miniszter úr is, Vas miniszter úr is annyira kiemelte ezeket a számokat és lehetőségeket, hogy ezek után a magam részéről már feleslegesnek tartom. Ugyanígy feleslegesnek tartóm felsorolni azt, ami az egészségügyi szervezeteik munkaerő-kiegészítése tekintetében történik. Itt 40.000 főről van szó, akik közül 5000 orvos.

A terv messzemenően gondoskodik a müvészetek felvirágoztatásáról is. A művészeti oktatás fejlesztésére az öt év alatt 70 millió forintot fordít. Új épületibe költözik a színművészeti és az iparművészeti főiskola, a zene- és képzőmüvészeti főiskolát pedig kibővítik.

Engedje mag a t[isztelt]. Ház, hogy ennél a pontnál ugyancsak a kultuszminiszter úrhoz egy kérdést intézzek. Az új múemlékvédelmi jogszabállyal

\footnotetext{
569 Az Ybl Miklós tervezte fóvámpalota a második világháború alatt súlyosan károsodott. 1948-ban kezdték meg újjáépítését. A közgazdaságtudományi egyetem 1950-ben költözött falai közé. Ma a Budapesti Corvinus Egyetem központi épülete (Budapest, IX. Fővám tér 8.)
} 
központosított múzeumi organizáció nem nélkülözheti tovább azt a kutatómunkát, amely minden jelentősebb gyüjtemény mellett megszervezett laboratóriumban folyik. E munkának az a célja, hogy a mütárgyra vonatkozóan, amely nemcsak kép vagy szobor, hanem egy bútor vagy egy régiség is lehet - a természettudomány lehetöségeinek felhasználásával tegyen megállapításokat és egészítse ki azt a munkát, amely kizárólag, státuskritikai alapon folyik. Csak a laboratóriumi munkával válik lehetővé teljes bizonyossággal például a hamisítások kimutatása, a mütárgyak korának meghatározása, a szerzők eredetiségének kimutatása. Ma, amikor a magyar kormány végre - nagyon helyesen - nagy gondolt fordít erre a területre, ezt a kis gesztust el nem hagyhatja. Múzeumaink anyaga a világ jelentősebb gyüjteményei között is kitűnő helyen szerepel. Nem volna helyes, ha elmaradnánk gyüjteményeink anyagának kezelésével és kritikai feldolgozásával Ha az ötéves tervben nem is, de a költségvetésben bizonyára alkalmat talál a kultuszminiszter úr arra, hogy javaslatomat megfontolás tárgyává tegye. Hozzáteszem: nem nagy összegröl van szó, de ezzel óriási értékeket menthetünk meg a köz javára.

T[isztelt]. Ház! A terv szociális vonatkozásairól is legyen szabad néhány szót szólnom, hiszen ezen a téren is annyi a tennivalónk, és talán nem is tudja elbírálni ennek a tervnek ezen a téren való jelentőségét az, aki nem élt éveken keresztül azok között az emberek között, akik alig éltek emberi sorban.

Az egészségügy és a szociálpolitika ötéves tervének elsőrendủ célkitüzése, hogy különösen az ipari munkásság és a dolgozó parasztság egészségvédelmét, illetőleg betegellátását, valamint szociális ellátását szolgáló intézmények számát növelje, a meglevő intézmények színvonalát emelje és a legkorszerűbb felszereléssel lássa el. E téren a két legjelentősebb intézmény: a kórház és a rendelőintézet. A rendelőintézetek, amelyek a szakorvosi ellátást biztosítják, a dolgozók legszélesebb rétegeit érintik. Az országban levő rendelőintézetek jelenleg naponta 65-70.000-es betegforgalmat bonyolítanak le. A jól kiépített rendelőintézeti hálózat ezenkívül a kórházakat is jelentős mértékben tehermentesíti.

A kórházak minőségi fejlesztésének, amint ez közismert, két összetevője van. Az egyik: a beruházási rész, a kórházaknak korszerü laboratóriumokkal, gépekkel, műszerekkel való felszerelése. A kórházi keret 30\%-kal szolgálja ezt a célt. A minőségi fejlesztés másik összetevője az, hogy a kórházakban elegendő számú és jól képzett szakszemélyzet álljon a betegek rendelkezésére. 
Itt sem kívánóik részletekbe menni. Érdekes adat azonban, hogy a minőségi fejlesztésnek jelentős gazdasági kihatásai vannak, mert ha az egy betegre eső átlagos kórházi ápolási időtartamot csak egy nappal is csökkentem, férőhely, szempontjából ez annyit jelent, mintha 2500 új kórházi ágy létesült volna. Érdemes tehát erre is gondot fordítani.

Örömmel halljuk, hogy a falu általános egészségvédelmének kiépítése érdekében az orvosi rendelöik tekintetében milyen tervek vannak; örömmel halljuk, hogy 60\%-kal emelik az eddigi létszámot, hogy 526 orvosi gépkocsi beszerzése van előirányozva, ez éppen azokon a helyeken fontos, amelyekről az előttem szólott igen t[isztelt] képviselőtársam ${ }^{570}$ beszélt. E helyeken az orvos eddig sokszor bizony fizikailag volt képtelen a beteget megközelíteni, mert például ott, ahol én voltam, az én plébániám területén ${ }^{571}$, amely 30.000 kat. holdon terült el, 11.000 hívőre bizony csak három orvos jutott. Tessék elképzelni, hogy azok az orvosok, akiknek nem volt fuvarjuk, kocsijuk, még lovas kocsijuk sem, bizony nem mindig rosszindulatból voltak képtelenek a betegeket ellátni; sőt a legritkább esetben rosszindulatból.

Az ötéves terv építési része különösen arról az oldaláról érdekes, hogy 180.000 új lakást épít. A vidéki városok ezzel valóban új arcot fognak kapni és végre eltünnek azok a nyomortanyák, azok a területek, amelyek majdnem minden városnak a végéhez oda voltak ragasztva, szégyenére a huszadik századnak, de elsősorban azoknak, akiknek lelkiismeretlenségétől függött, hogy ezek a nyomortanyák és ezek a területek ilyen

570 Gém Ferenc (1912-1992) - korábbi nemzeti parasztpárti - kommunista politikus a vidéki Magyarország egészségügyi ellátásának javulása kapcsán fogalmazta meg a következőket. „De ezt a célt szolgálja közvetve az a hét és fél milliárd forint is, amelyet ötéves tervünk a közlekedésre irányoz elő, mert megszünteti azt az áldatlan állapotot, amelyben dolgozó parasztságunk évszázadokon keresztül kínlódott, hogy távol a várostól tanyán, falvakban, út és közlekedés hiányában, a szegénység és nincstelenség kínjában, orvos és gyógyszer nélkül fetrengett különböző betegségekben, sokszor egész családjával. De az is nagyon sokszor megtörtént, hogy míg a férfi odavolt valahol dolgozni és kenyeret keresni, a gyermek beteg lett és az asszony keservesen sírt, mert hiába ment el az orvoshoz, azok rendszerint ismerték és azt kérdezték tőle. van-e pénze, és ha nem volt, nem mentek ki, vagy ha mégis az orvos olyan jólelkü volt és megvizsgálta a beteget, akkor meg orvosság nem volt, mert a patikusok nem igen adtak hitelbe. Nem is beszélek arról, hogy a parasztasszonyok ezrei és tízezrei orvos és szülésznő nélkül, szülték gyermekeiket, aminek nagyon sok esetiben az lett a következménye, hogy meghaltak gyermekestül együtt.” Az 1949. évi június hó 8-ra összehívott Országgyülés naplója. 1. köt. Budapest, 1950. 1949. június 8. - 1949. december 22. 322-323.

571 Szeged-Alsóközpont (a mai Mórahalom), ahol Balogh páter 1933 márciusa és 1946 márciusa ténylegesen 1944 decembere - között volt plébános. 
állapotban maradtak. Mondom, végre el fognak tünni ezek a nyomortanyák, és így a dolgozók mindnyájan emberhez méltó egészséges lakáshoz jutnak.

Nagymértékben segítünk a falu ivóvízellátásán azzal, hogy - mint hallottuk - az ötéves terv 2000 egészséges ivóvizü, mélyfúrású kutat létesít.

T[isztelt]. Ház! Békés szándékaink öszinteségét mi sem bizonyítja jobban, mint az, hogy míg az ötéves tervben bőven jut paragrafus és pénz ipari, mezőgazdasági, kulturális, népjóléti és sok egyéb célra, addig háborúról, fegyverkezésről csak annyit mondunk, hogy honvédelmünk, véderőnk kifejlesztését a békeszerződés rendelkezései szerint tartja feladatának az ötéves terv. Honvédségünkre is csak azért van szükség, mert csak így tudjuk betölteni szerepünket a Szovjetunióval, a baráti népi demokráciákkal együtt a béke védelmében, a lelkiismeretlen háborús törekvésekkel szemben.

Magamévá teszem M. Szuszlovnak ${ }^{572}$ a béke lehetőségéről vallott felfogását, amelyet a Tartós békéért, népi demokráciáért ${ }^{573}$ címü lap december 3-iki száma hozott. „Mélységes tévedés volna - írja - ha azt hinnők, hogy lehetetlenség elkerülni a háborút.” E véleményét többek között a következőképpen támasztja alá: „A szovjet kormány külpolitikája és kölcsönös viszonya a kapitalista államokkal, abból indul ki, hogy lehetséges a szocialista és kapitalista rendszerek egymás melletti fennállása és lehetséges köztük a békés együttmüködés is. Sztálin - folytatja Szuszlov - már 1934ben egészen pontosan és határozottan a következő szavakkal fogalmazta meg ezt a politikát: »Külpolitikánk világos. E külpolitika: a béke megőrzésének és a kereskedelmi kapcsolatok fejlesztésének politikája valamennyi országgal. A Szovjetuniónak esze ágában sincs, hogy akárkit is fenyegessen, még kevésbé, hogy bárkit is megtámadjon. Mi a béke mellett vagyunk és a békéért harcolunk. De nem fékünk a fenyegetésektől és készek vagyunk rá, hogy a háborús uszítók csapására csapással feleljünk.«"

A magam részéről hiszem, hogy az emberiség sorsának intézői, akik szemben állnak a sok százmillió embert magában foglaló békefronttal, amelynek élén Sztálin generalisszimusz áll, még a végső pillanatban is elhárítják maguktól azt a felelősséget, amelyet elsősorban számukra jelentene egy újabb háború, és meg fogják találni azokat a súlyos, de mindvégig békés érveket, amelyek alkalmasak arra, hogy megmentsék az emberiséget olyan háborútól, amely Európa pusztulása lenne.

\footnotetext{
${ }^{572}$ Szuszlov, Mihail Andrejevics (1902-1982) a Szovjetunió Kommunista Pártja Politikai Bizottságának tagja, a szovjet rendszer egyik vezető ideológusa, 1949 és 1951 között a Pravda főszerkesztője.

573 Tartós békéért, nép demokráciáért $=$ a Kominform lapja.
} 
T[isztelt]. Országgyülés! Miután a béke felett való őrködés tekintetében mindannyian, az országgyúlés tagjai és a választók milliói egyek vagyunk, és miután az ötéves terv dolgozó magyar népünk anyagi és kulturális fejlödését szolgálja, s az életszínvonal komoly mértékben, való emelésére alkalmas, mindenekfelett pedig a békéért való küzdelmünknek hatalmas eszköze: a törvényjavaslatot elfogadom. (Taps.) 


\section{KÉPEK, DOKUMENTUMOK}

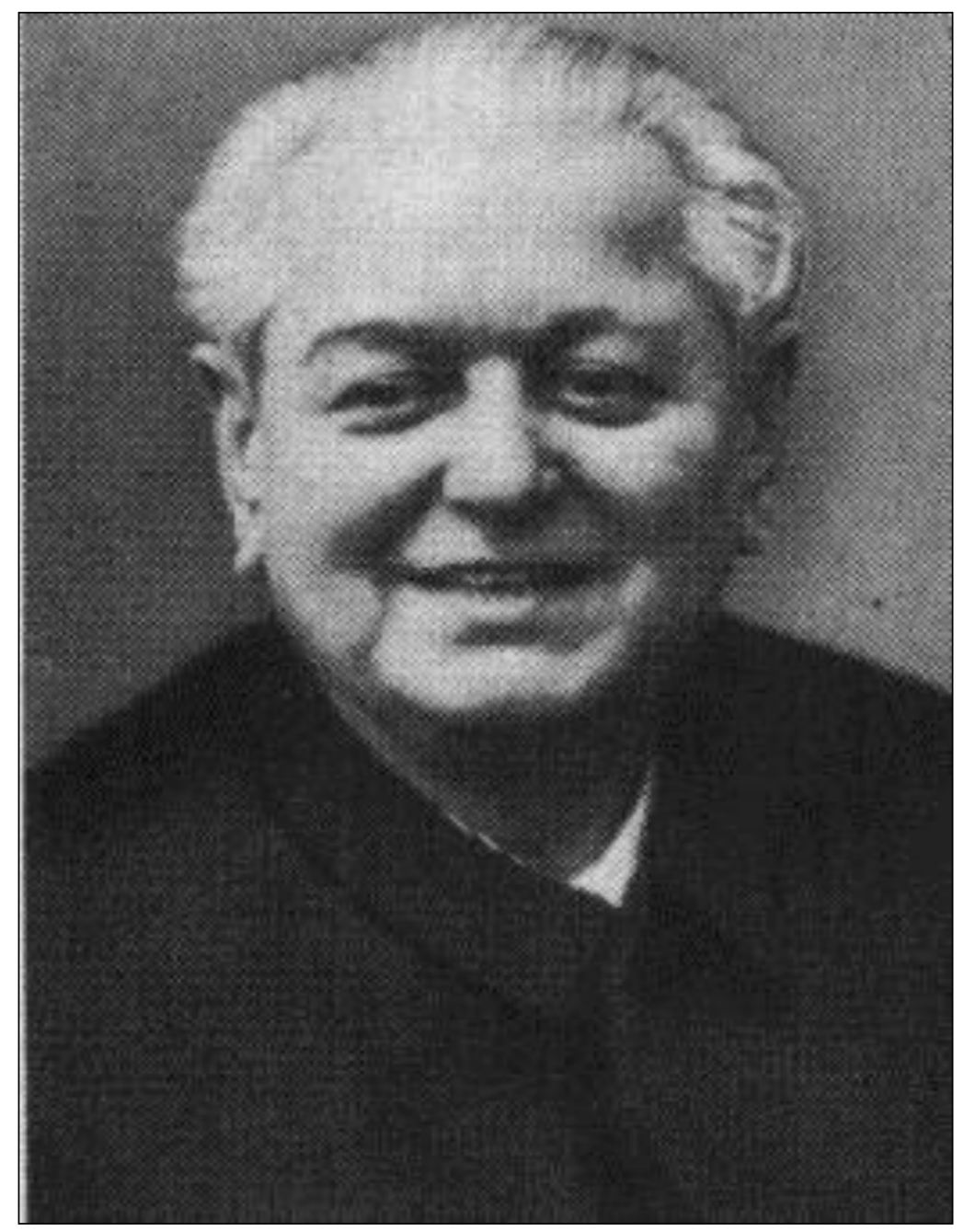

1. Dr. Balogh István római katolikus pap, államtitkár, parlamenti képviselö, pártelnök.

(Stájerlak, 1894. március 30. - Budapest, 1976. július 20.) 


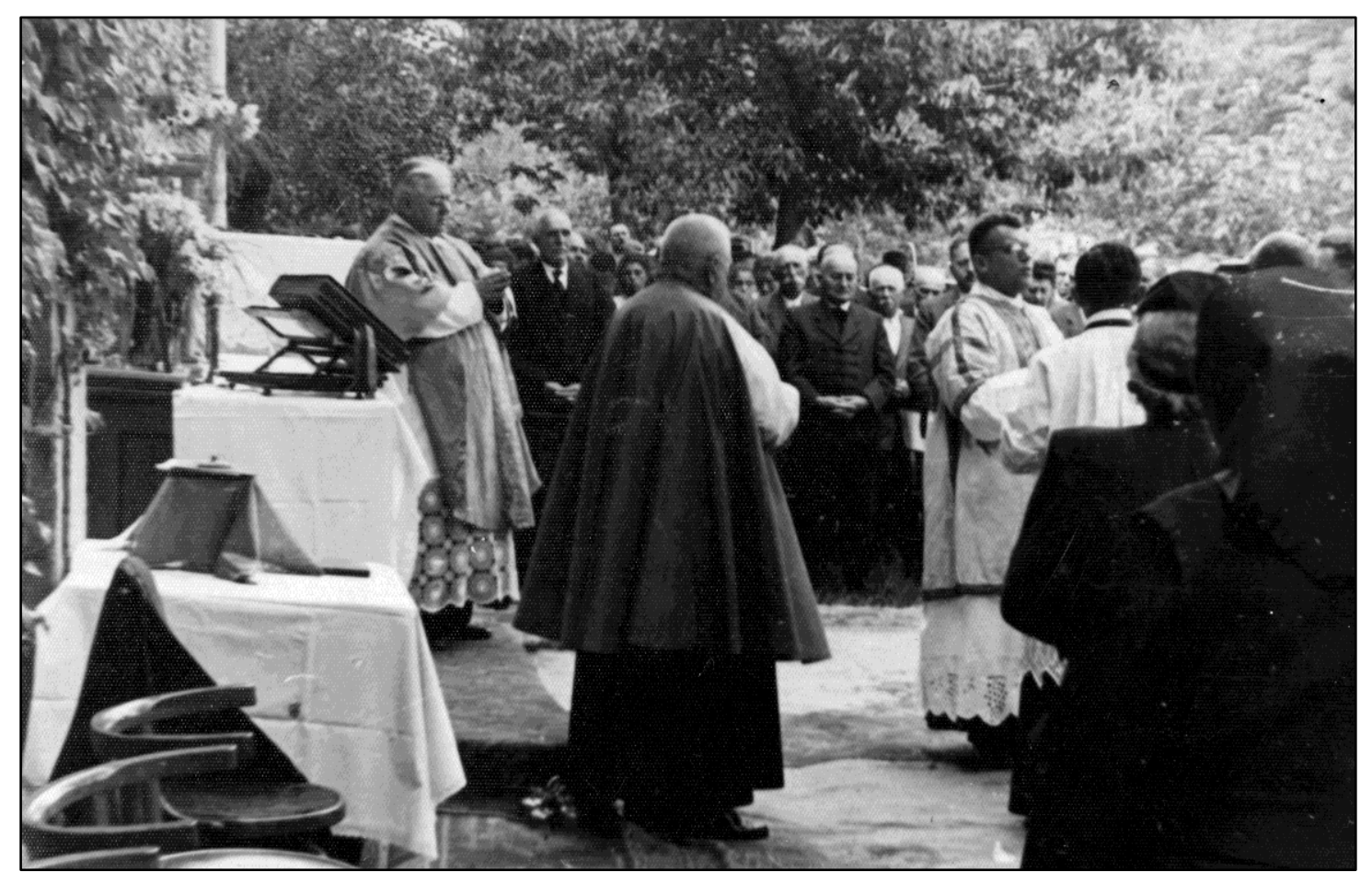

2. Balogh páter szentmisét mutat be Szeged-Alsóközponton.

Az 1930-as évek második fele.

(Móra Ferenc Múzeum. Történeti Fényképtár.)

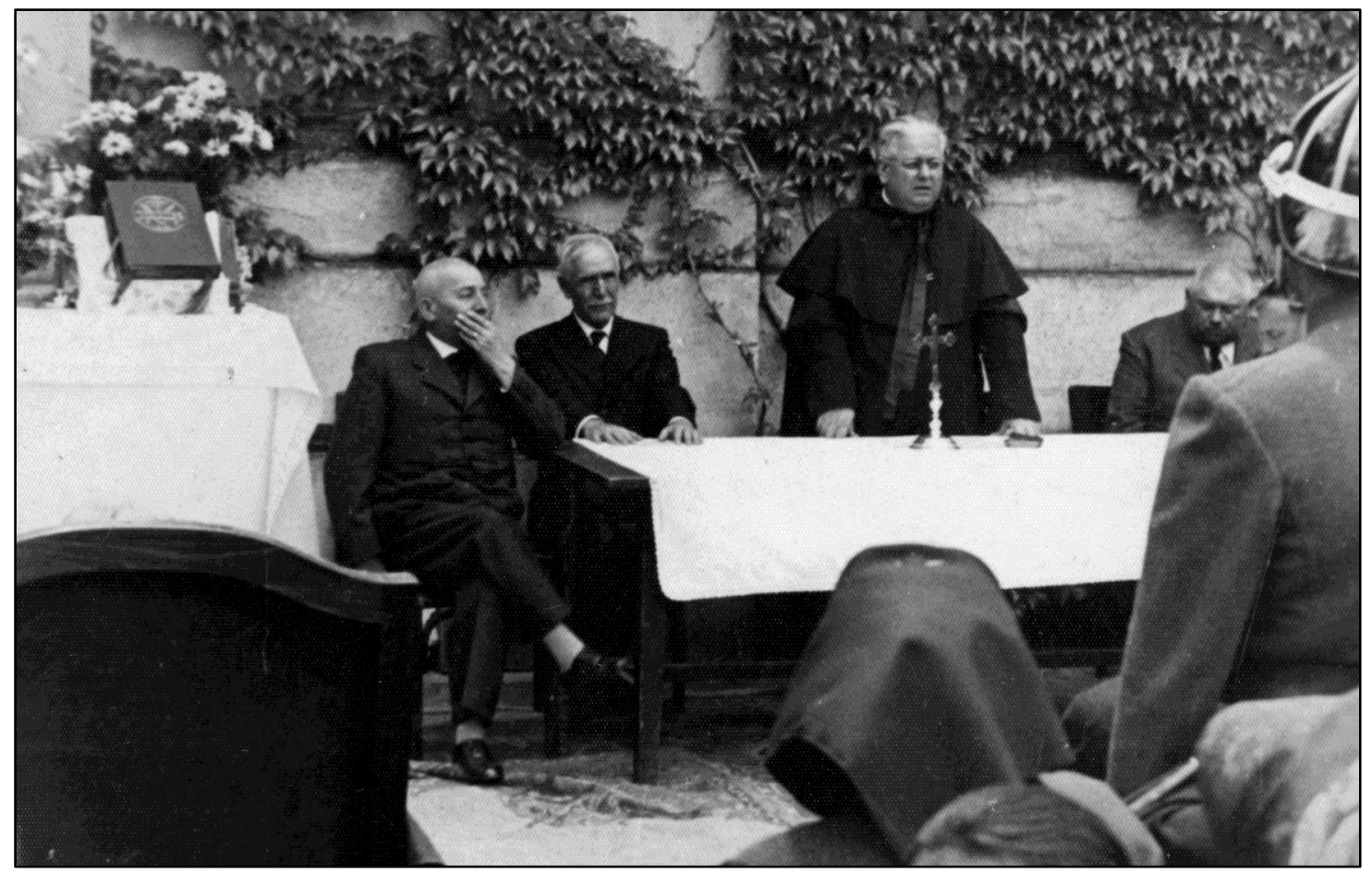

3. Balogh István beszédet mond Szeged-Alsóközponton.

Az 1930-as évek második fele.

(Móra Ferenc Múzeum. Történeti Fényképtár.) 


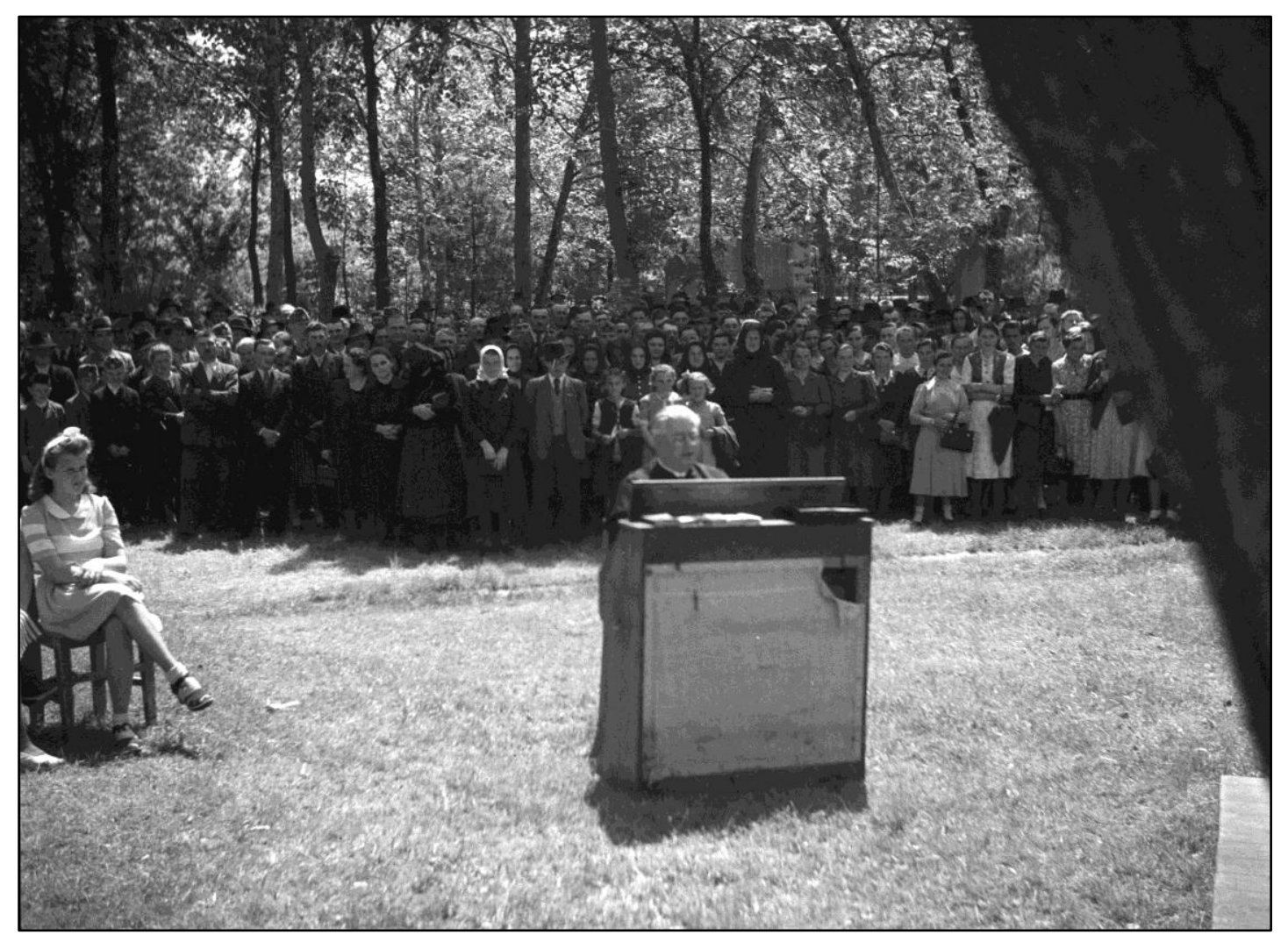

4. Balogh István énekvizsgán vesz részt Szeged-Alsóközponton.

Az 1930-as évek második fele.

(Móra Ferenc Múzeum. Történeti Fényképtár.)

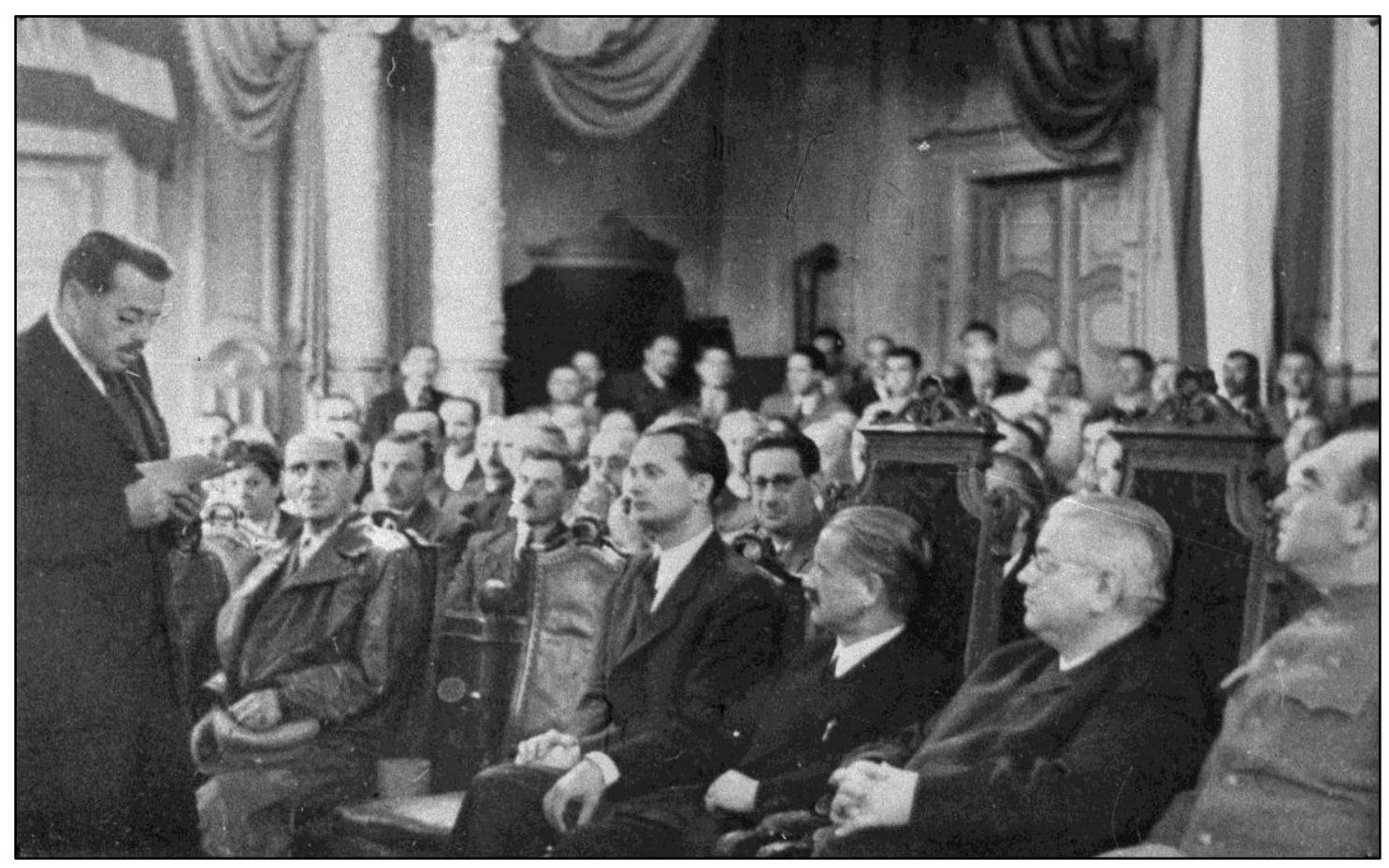

5. Kisgazda politikusok a szegedi városházán 1945-ben.

Az első sorban Balogh mellett Tildy Zoltán és Ortutay Gyula. Szirmai István beszél. (Móra Ferenc Múzeum. Történeti Fényképtár.) 


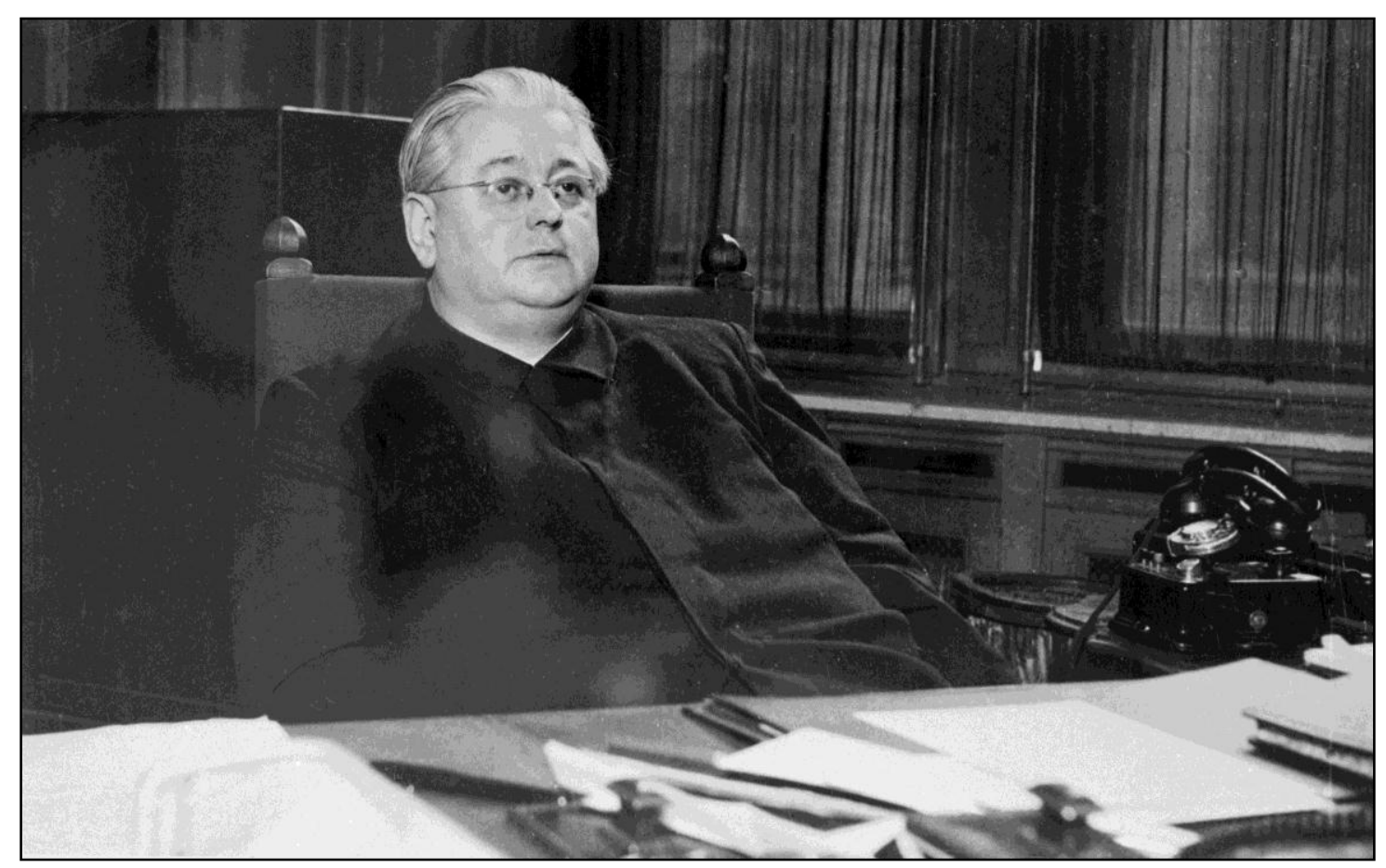

6. Balogh István parlamenti dolgozószobájában 1945 őszén.

(Móra Ferenc Múzeum. Történeti Fényképtár.)

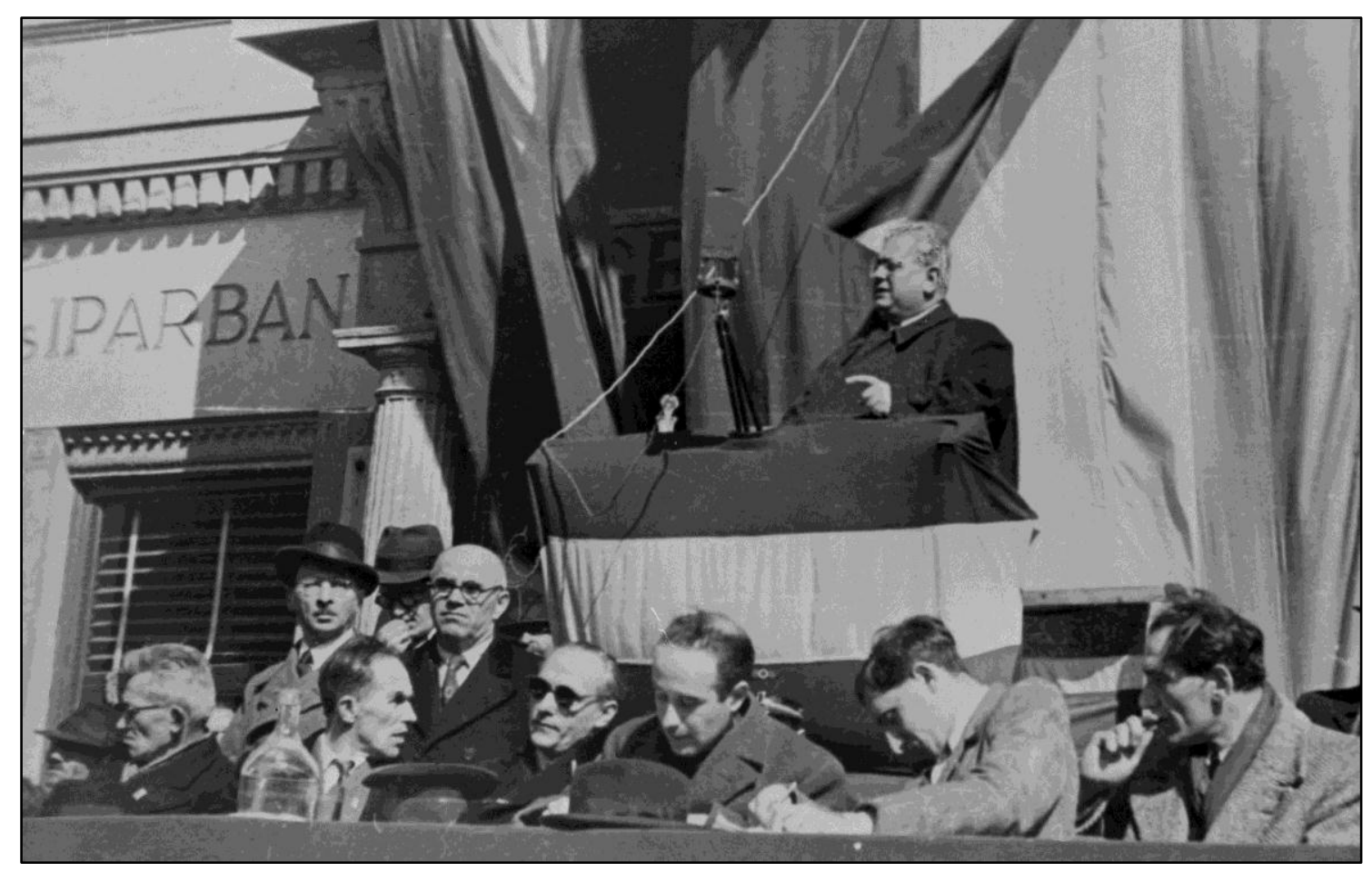

7. Balogh páter ünnep beszédet mond a szegedi Klauzál téren. 1946. március 15. (Móra Ferenc Múzeum. Történeti Fényképtár.) 


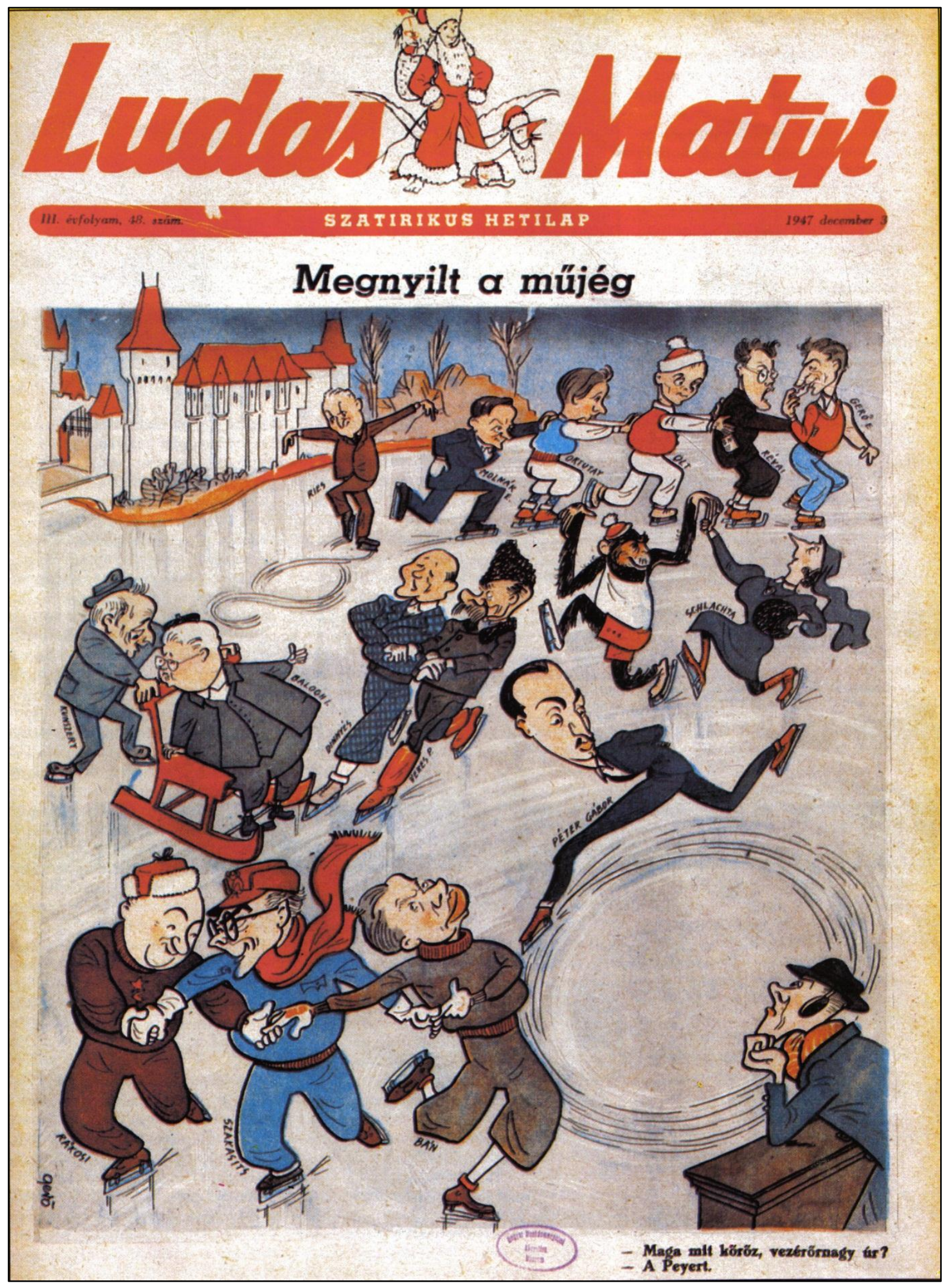

8. Politikai karikatúra 1947 végéről.

Balogh pátert Kunszery Gyula tolja, Péter Gábor Peyer Istvánt körözi, Rákosi Mátyás, Szakasits Árpád és Bán Antal pedig kéz a kézben járnak.

(Ludas Matyi, 1947. december 3.) 


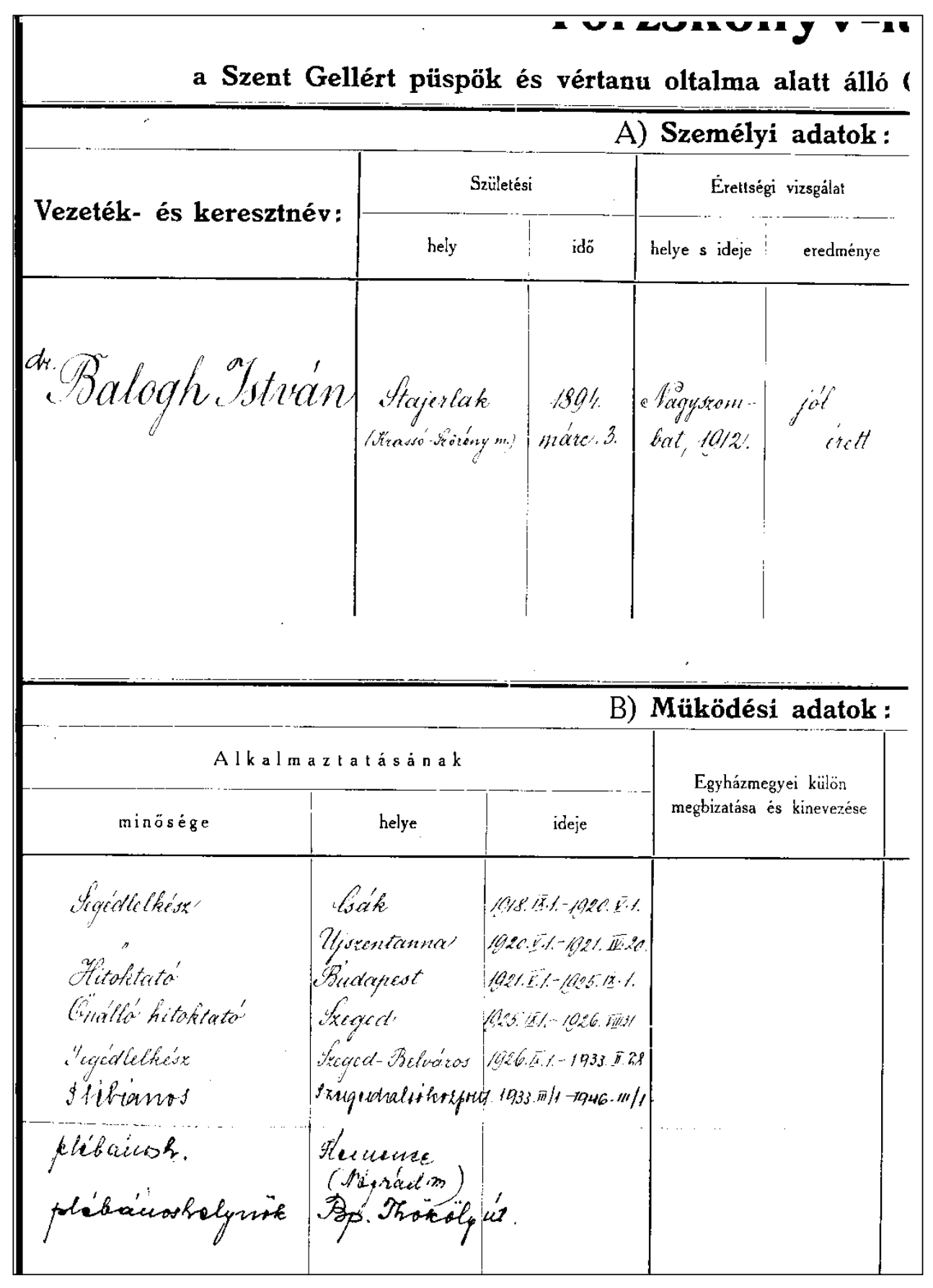

9. Balogh István egyházmegyei törzskönyvi lapja.

(SZCSPL Csanád egyházmegye papságának törzskönyvlapjai, 62. sz.) 


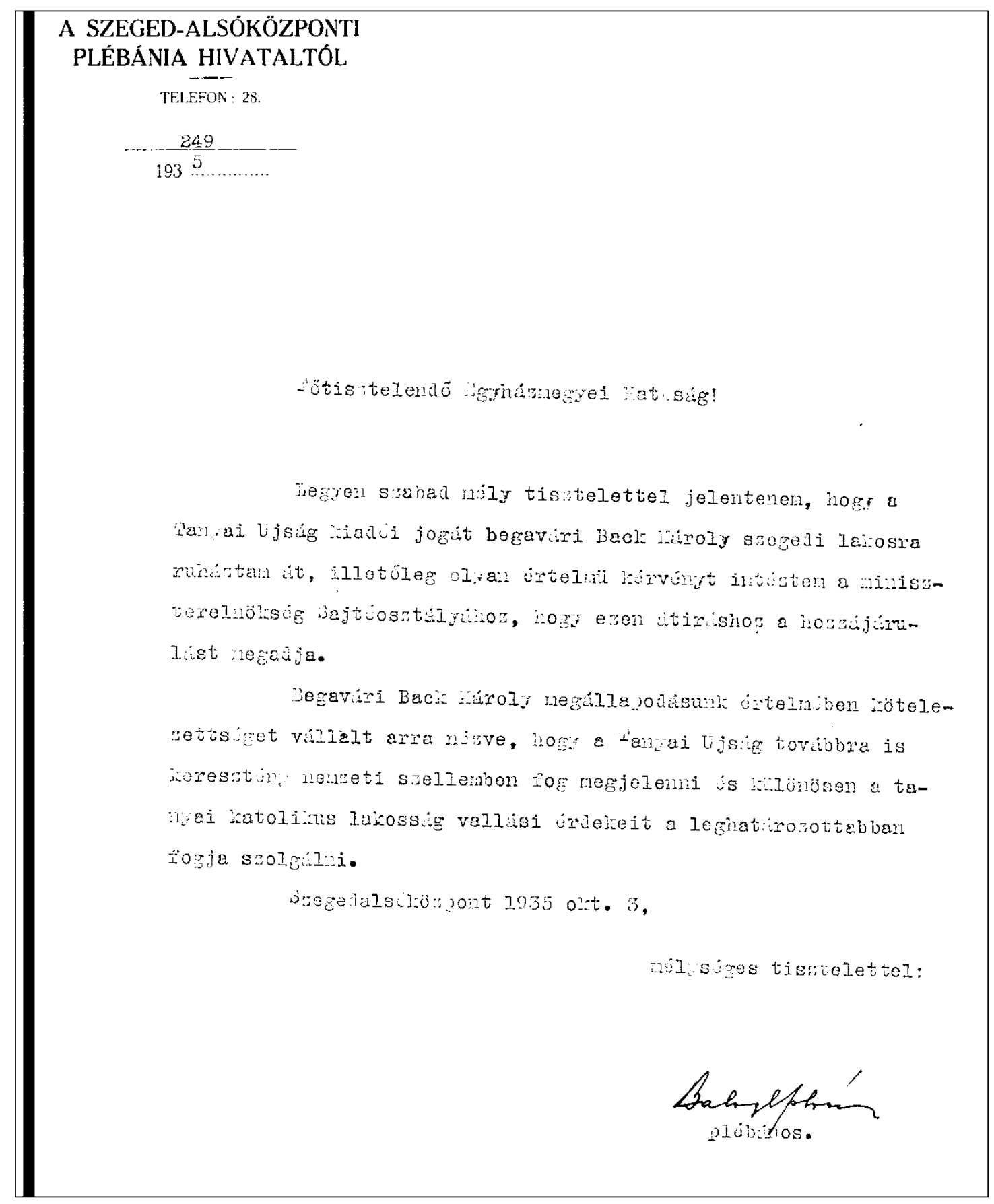

10. Balogh páter levele az egyházmegyei hatóságnak a Tanyai Újság kiadói jogának átadásáról. 1935. október 3.

(SZCSPL PHEI 2774/1935.) 


\section{Kedves Brlogh!}

A városi föszámvevő ur nagyon panaszkodott egy dignitariusnak, hogy a Délmagyarország őt személyében támadta mert üzlet1 els zámoĺás 1 ügyben kötelességszerüen a város álláspontját képv1selte. Azt akartam a jo embernek üzenn1, hogy $11 \mathrm{y}$ mucsa1 1zléstelenséget nem kell trag 1kusan venn 1, mert ha az ország tele van ujságirókkal akik nem tudnak ujságot 1rn1, hát mért ne legyen ép a Délmagyarországnál. De akkor jött a refrén: Balogh! A pap! 乌 ennél meg kell állnom.

Kifejtettem önnek már 1 smételten, mily tapintatot tételez fel pap1 jellege az ujságszerkesztéssel kapcsolatban tekintettel a mi jốndulatu közéleti tényezôink érzékenységére is. Ha ennek dacára ezt a müvelete t nem tudja lebonyolitan 1 kötekedő személyeskedés nélkül, akkor nem marad más hátra mint az a választás, hogy vagy megszüntet minden kapcsolatot a sajtóval vagy nyugdi jazását kér1 s ezt a döntést kibuvót kizáró módon fognám féleértés ujabb felmerülése esetén provokálni.

Fõpásztor1 áldással:

Gyula s.k.

püs pök

Szeged, 1940.febr.10.

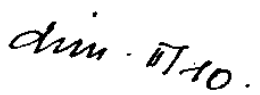

11. Glattfelder Gyula csanádi püspök levele Baloghnak, amelyben újságírói tevékenységének befejezésre szólítja föl. 1940. február 10.

(SZCSPL PHEI 506/1940.) 


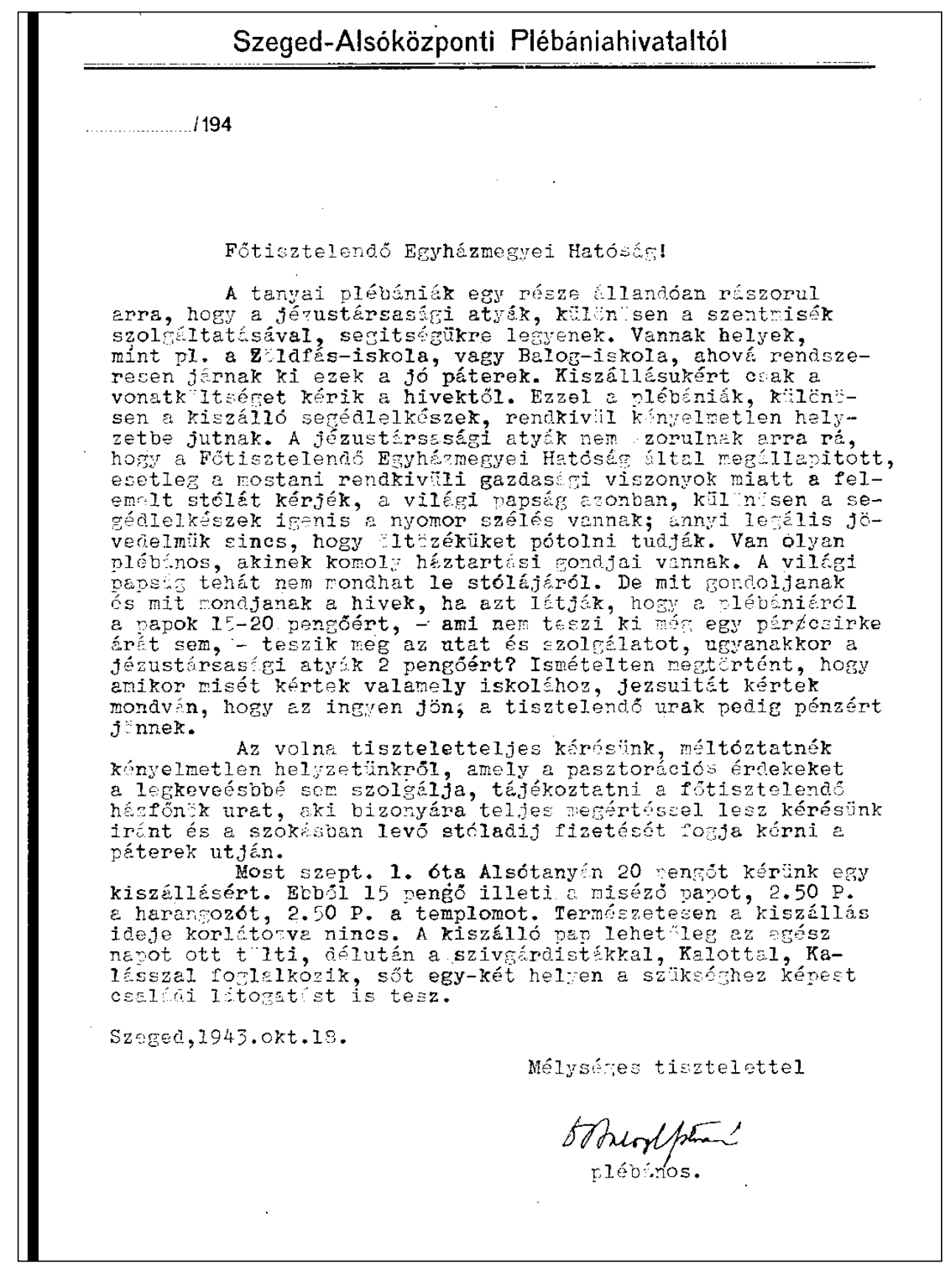

12. Balogh István plébános jelentése az egyházmegyei hatóságnak a jezsuita szerzetesek lelkipásztori kisegítő tevékenységéről. 1943. október 18.

(SZCSPL PHEI 2680/1943.) 
MINISZTERELNÖKSÉG

POLITIKAI ÁLLAMTITKÁR

\section{FOTISZTELENDÓ EGYHAZMEGYEI HATÓSAG !}

Kézhezvettem az értesitést, mely szerint az érvényben lévo Canonok értelmében szabadságom meg nem hoszszabbitható és folytatólagos távoilétem miatt a Szegedalsóközponti plébánia megürültnek tekintendó.

A Canonok rendelkezéseit illỏ tisztelettel tudomásulveszem és hiveim iránt mindenkor érzett szeretetem miatt sajnálattal bár és kizárólag más, ugyancsak fontos szolgálati érdekból plébániámról ezennel lemondok.

Oszintén kivénom, hogy az a bensôséges víszony, amelyben eddig a csanádi egyházmegyével voltam, s amely Istenben boldogult Gyula püspök emléke miatt is elszakithatatlan, mostani Ordináriusunk iránt érzett tiszteletem és nagyrabecsülésem által még inkább megszilárdult, a jövóben is változatlan marad, s azt a magam részérôl hũségesen ápolni fogom.

Budapest, 1946. évi március hó 6-án.

Mélységes tisztelettel:

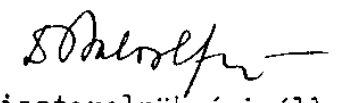
miniszterelnökségi államtitkár.

13. Balogh páter szeged-alsóközponti plébánosi állásáról lemondó levele. 1946. március 6.

(SZCSPL PHEI 1101/1945.) 
A xinisztertanács 1945 .évi november hó 19. napjén kelt javaslatára az Ideiglenes Nemzetgyuilés elnökségének nevében

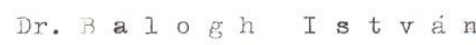

Kelt: Budapesten,1945. vivi nofember hó 22. napján.

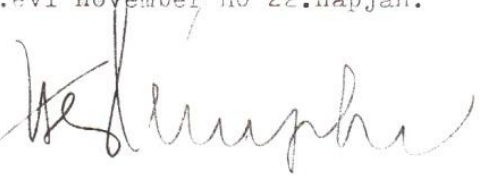

az Ideiglenes Nemzetgyilés elnöke.

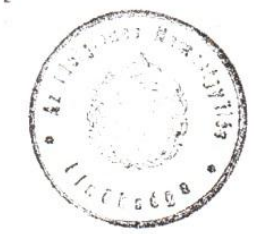

Magyar Oromgos

Lovoltár

14. Balogh István miniszterelnökségi politikai államtitkárrá való kinevezése.

1945. november 22.

(MOL XVIII-5.) 
tünkön elhelyezni és eltartani, de ugyanakkor idegen nemzetbelieknek adnánk helyet. Ilyen eljárással magunk alatt vágnók a fát minden irányban.

Fogadja lliniszterelnök Ur tiszteletem őszinte nyilvánitását.

Esztergom, 1946. január 2.

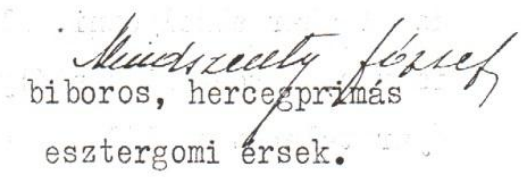

$\frac{\text { Salogh àll. } \text {. u't }}{\text { Kenitren nalmet }}$

Tovaces. B. inforrua' ciajal is fiqulewere vève.

a kirrét ban fereuced

erpir noviteties ill. tounesir coile (. Elleworio Miz.) - folelal: semmi ifen tery, veen ters mics. $\pi$.

15. Mindszenty József hercegprímás levele Tildy Zoltán miniszterelnöknek, a kormányfö glosszájával, amelyben Baloghot utasítja a válasz megírására. 1946. január 2.

(SZCSPL HBI 58.) 
1714/1946. S2.

Alantitkér Ur !

Oeninenciája tévollétében és megbizásából enged-

je me Államtitrár Ur, hogy tisztelettel megköszönjom azt

a szives fáradozását, melynek gyünölcse az egyházi közi-

gazgatás részére megszavazott összegek rendes időben va-

ló negérkezése leend.

Amidőn a magam köszönetét is tolmácsolom ôszin-

te tiszteletern nyilvánitásával vagyok

Esztergom, 1946. április 2.

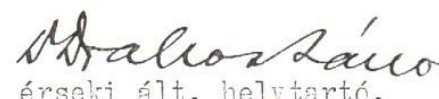

érseki ált. helytartó.

Dr. $B$ a 10 \& $h$ Is $t \mathrm{v}$ án úrnak,

állantitkér.

Budapest.

V.Miniszterelnökség.

Lossuth Iajos-tér.

16. Drahos János érseki helynök - Mindszenty József és az esztergomi főegyházmegye nevében fogalmazott - köszönőlevele Balogh páternek.

1946. április 2.

(SZCSPL HBI 96.) 
MINISZTERELNÖKSÉG

POLITIKAI ÁLLAMTITKÁR

Szigorúan bizalmas !

MINISZTER UR !

Hivatkozással szóbeli megbeszélésünkre, felkérem Kiniszter Urat, hogy a Miniszterelnök Ur Békeelôkészitési Rendelkezési Alapja javára a Masyar Nemzeti Bank útján 100.000, azaz Egyszázezer dollárt kiutalni sziveskedjék.

A fenti összeg a Magyar Nenzeti Bank egy külön tresorjában helyezendő el és annak kezelése tekintetében a Bank elnöke útján kiulön intézkedés fog történni.

Budapest, 1946. évi szeptember hó 17-én.

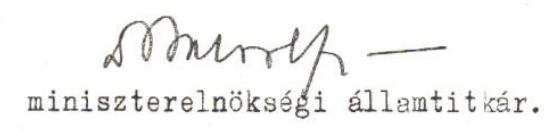

RÁCZ JENÓ úrnak,

magyar pénzügyminiszter

BUDAPEST.

17. Balogh István levele Rácz Jenő pénzügyminiszternek.

1946. szeptember 17.

(PIL 274. f. 7/150. ő. e. 5.) 
Budapest, 1949. junius 14.

Kedves Barátom !

Dr.Rogács Ferenc pécsi segédpüspök
fizetésével kapcsolatos leveledre válaszolva értesitlek, hogy, a segédpüspöki fizetést elvi okokból nem folyósithatjuk. Dr. Rogáes Ferencet ugyanis utódlási joggal a Vatikán nevezte ki, anélkiul, hogy ehhez a kormány hozzájárulását kérte volna. Fizetése folyósitása tehát a Vatikán eljárásának elismerését jelentené és nem kivánatos precedenst szolgáltatna. Baráti üdvözletét kiula di

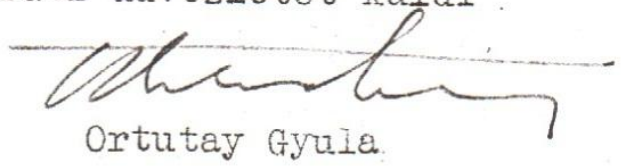

dr. Balogih István

képviseló urnak

Budapest.

18. Ortutay Gyula vallás- és közoktatásügyi miniszter levele Balogh Istvánnak Rogács Ferenc pécsi segédpüspök fizetésének ügyében.

1949. június 14.

(SZCSPL HBI 485.) 